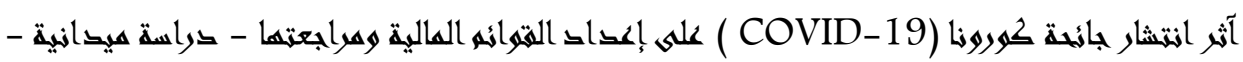
د/ وليخ سمير عمب العظيه الجبلمى

آثر انتثار جائحة كورونا (COVID-19 ) على إعداد القوائم المالية ومراجعتها

$$
\text { ـ دراسة ميدانية - }
$$

د/ وليد سمير عبد العظيم الجبلى

مدرس بقسم المحاسبة و المراجعة الجئة

معهز العبور العالى للإدارة والحاسبات ونظم المعلومات

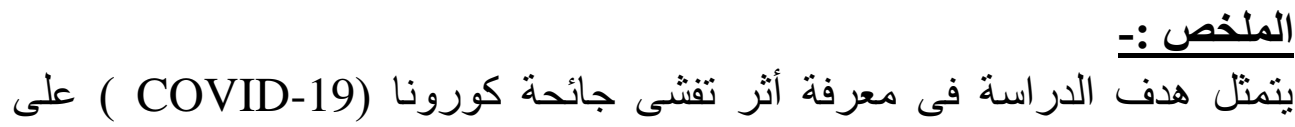

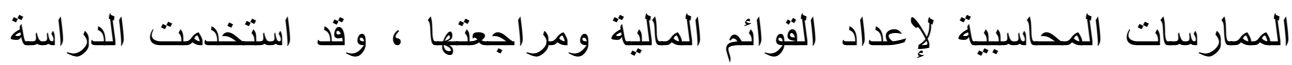

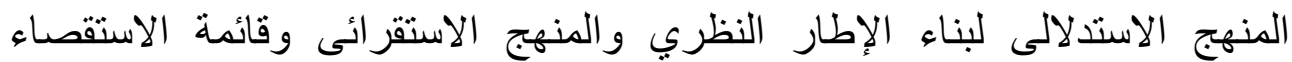

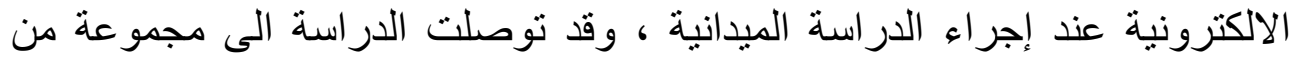

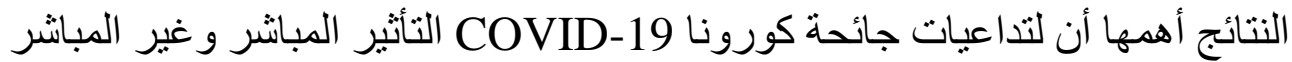

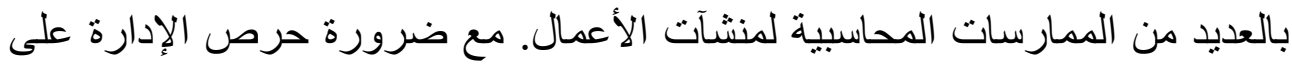

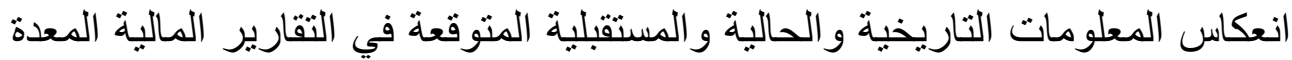

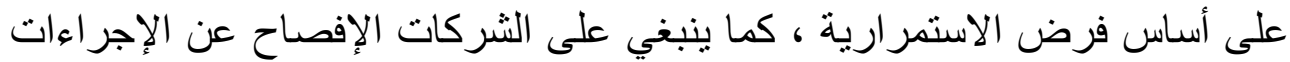

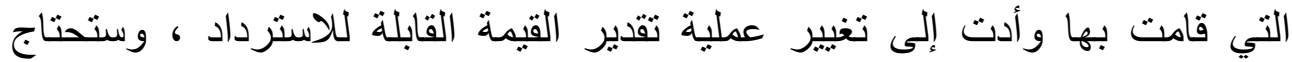

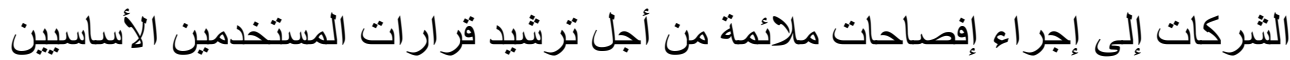

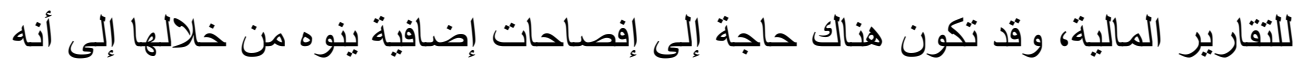

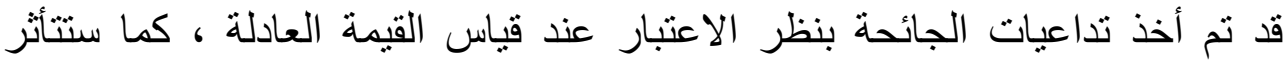

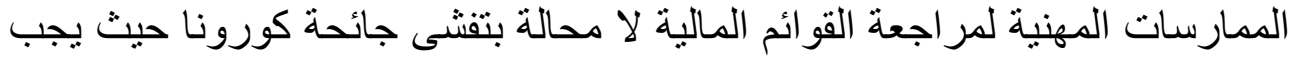

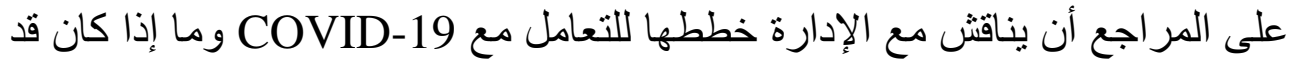

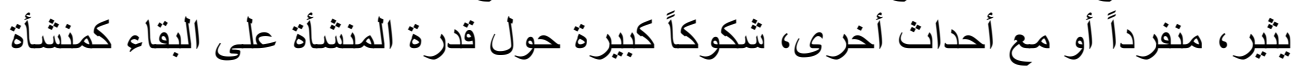

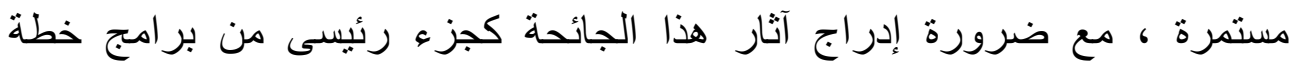

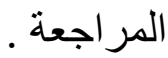




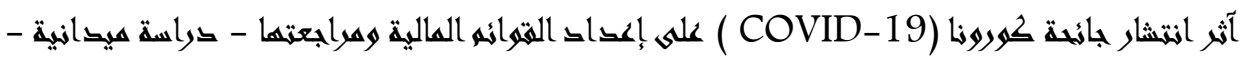
د/ وليق سمير عبد العظيه الجبملى

الكلمات المفتاحية :- COVID-19 ، الممارسات المحاسبية ، إعداد القوائم المالية ، الممارسات المهنية للمر اجعة.

\section{Abstract :-}

The aim of the study is to know the impact of the COVID-19 on accounting practices for preparing and auditing financial statements. The study used the inferential approach to construct the theoretical framework, inductive approach and electronic survey list when conducting the field study, and the study reached a set of results, the most important of which is that The implications of the COVID-19 have direct and indirect impacts on many business practices. With the necessity of the administration's keenness to reflect the expected historical, current and future information in the financial reports prepared on the basis of imposing continuity, companies should also disclose the procedures that they have taken and led to changing the process of estimating the recoverable value, and companies will need to make appropriate disclosures in order to rationalize the decisions of users The basic principles of financial reporting, and additional disclosures may be required through which it is noted that the repercussions of the pandemic have been taken into account when measuring the fair value, and professional practices for reviewing the financial statements will inevitably be affected by the outbreak of the Corona pandemic as the auditor should discuss with the management its plans for dealing With COVID-19 and whether it raises, individually or with other 


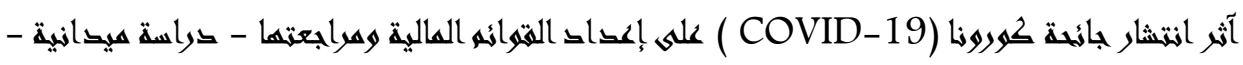
د/ وليب سمير عبد العظيه الجبلمى

events, significant doubts about the facility's ability to survive as a continuous facility, with the effects of this pandemic must be included as a key part of the audit plan programs.

Kay words :- COVID-19, accounting practices, preparation of financial statements, audit professional practices.

تمتد آثار الأزمات والكوارث مثل الأزمة الحالية التي يسبها انتشار فيروس كورونا

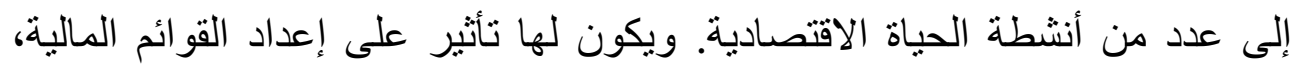

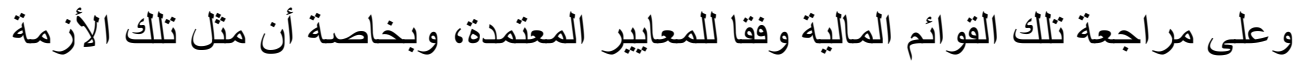

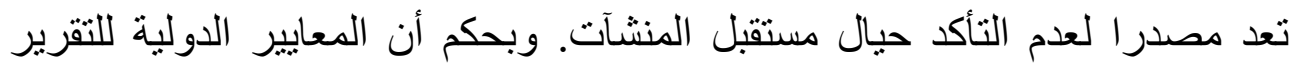

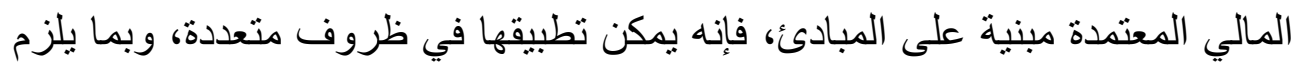

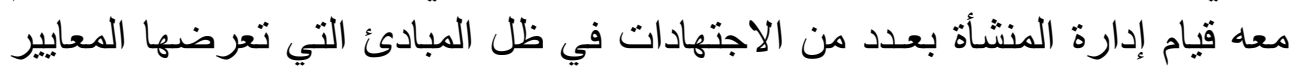
وفقا لظروف المنشأة . مان. أن جائحة كورونا (Covid-19) مشكلة عالمية تهيمن على العناوين الرئيسية، وهو

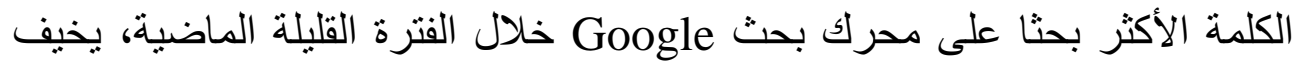

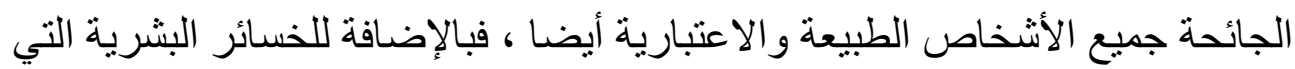

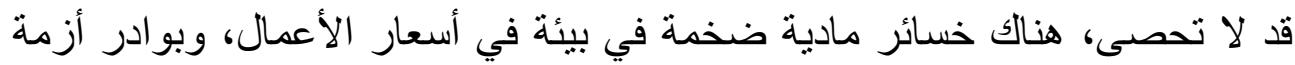

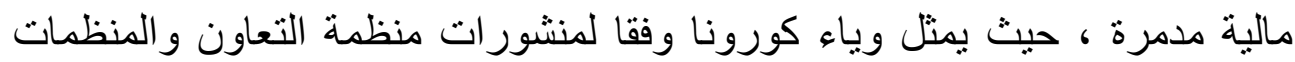

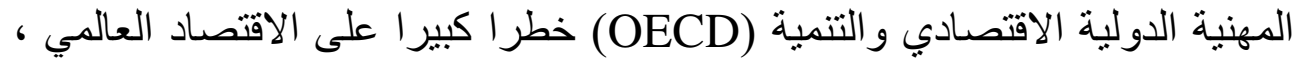

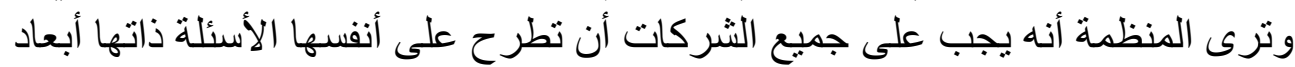

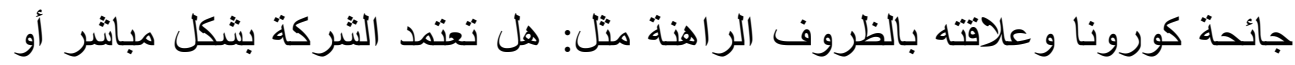

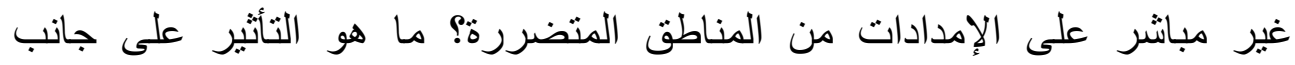

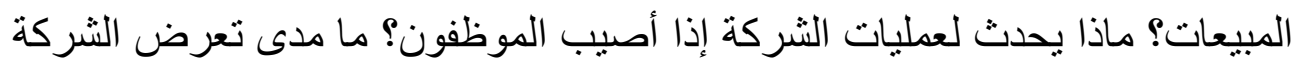
لتقلبات أسعار السوق؟ ما هو التأثثر على التدفقات النقدية للشركة؟ ستعطي الإجابات 


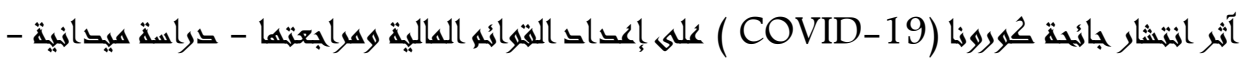
د/ وليد سهير عبد العظيه الجبلمى

على مثل هذه الأسئلة إنشارة أولية إلى مدى خطورة الوضع.( Samet Gunay

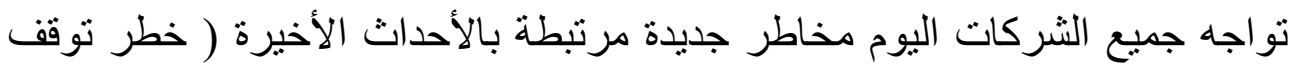

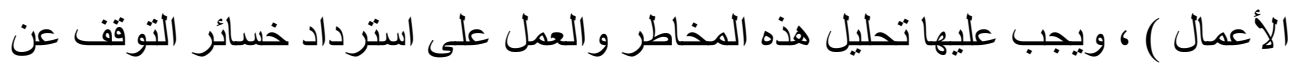

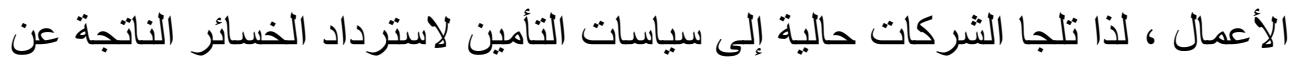

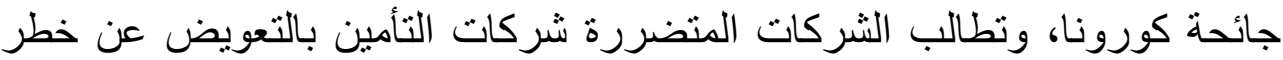

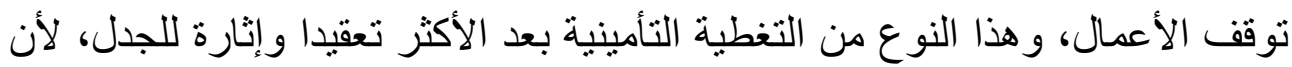

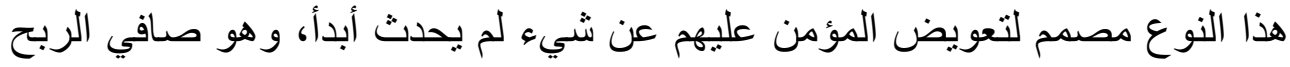

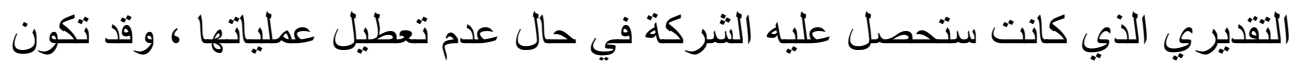
الخسائر قابلة للاسترداد ولكنها عملية معقدة من الناحية التخطيطية وتتطلب خبر فيرات متخصصة في التأمين و المحاسبة .

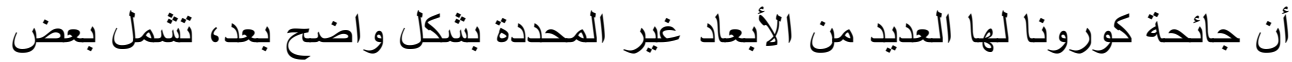

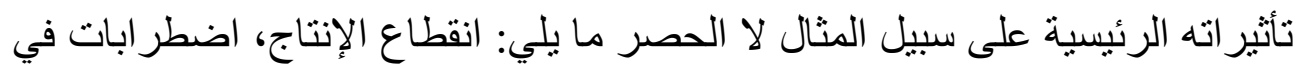

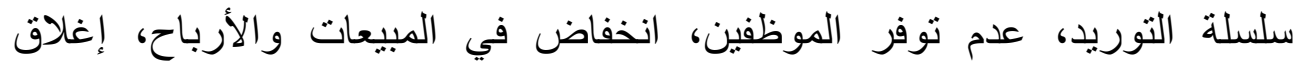

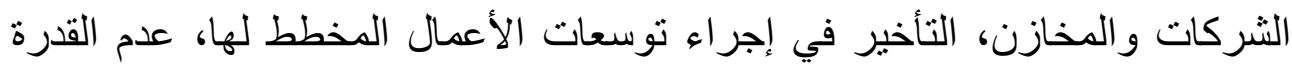

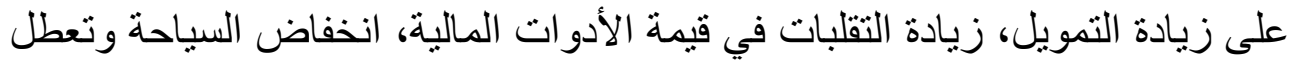

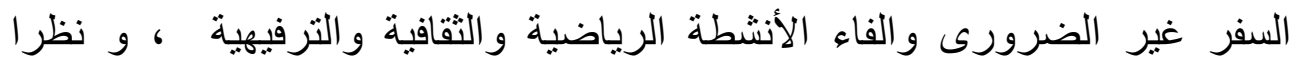
للتغيرات التي وقعت في بيئة شركات الأعمال والمتمثلة في النتشار جائحة كورونا

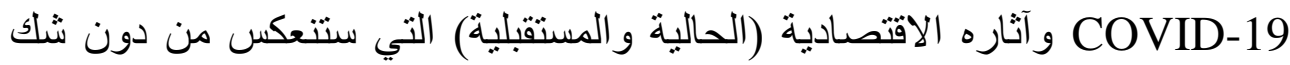

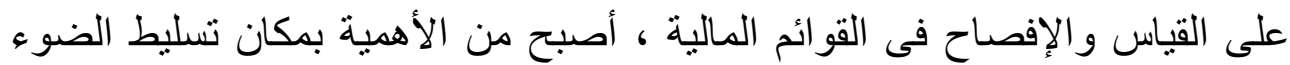

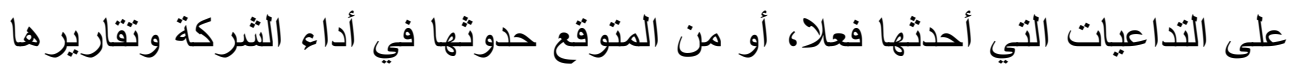

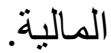
وقد يو اجه المر اجعون صعوبات عديدة للممارسة أعمالهم فى مثل هذه الظروف حيث يمكن النظر إلى الظروف المصاحبة لانتشار فيروس COVID-19 على أنها مثال فئل 


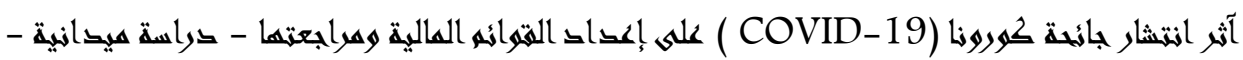
د/ وليد سهير عبد العظيه الجبلمى

و اقعي لاعتبار حضور الجرد الفعلي للمخزون غير ممكن عمليا نظر الما يشكله من إن إنها خطر على سلامة المراجعين ، وفي خضم جائحة المراجعون حالات تكون فيها مواقع الجرد مغلقة، أو تكون مفتوحة مع عدة عدد محدود

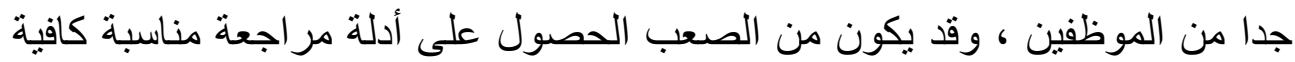

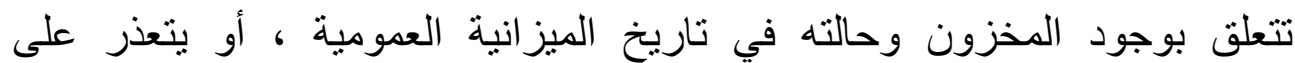

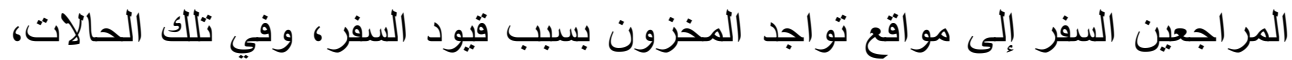

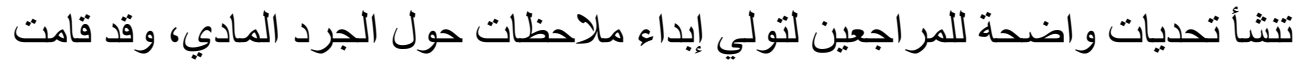

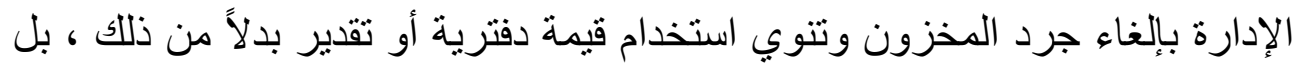

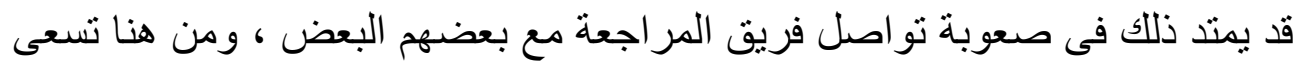

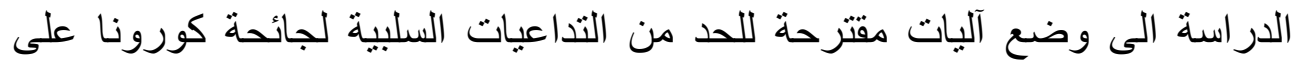

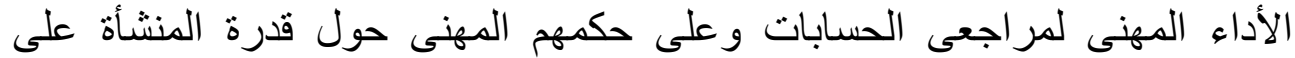
الاستمر ارية. وبناء على ما سبق بمكن صباغة مشكلة البحث بالتساؤل الآتي:ما هو أثر تفشى جائحة كورونا (COVID-19 ) على الماتئ الممارسات المحاسبية

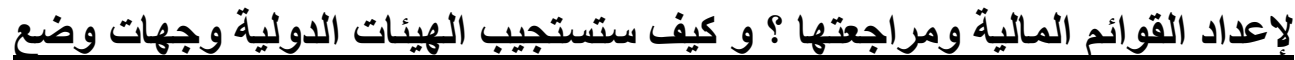

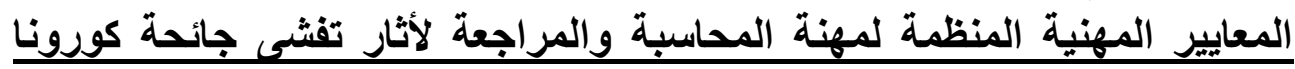

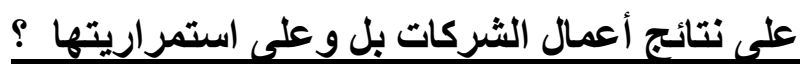

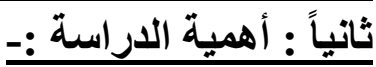

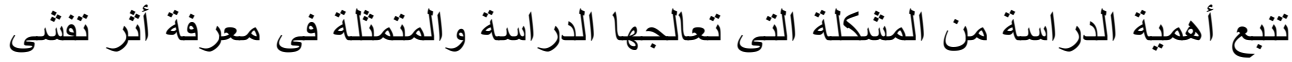

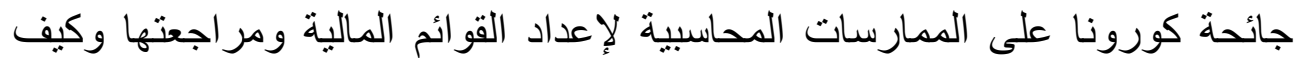

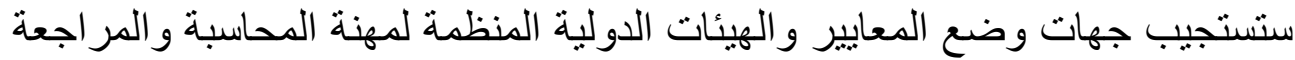
لأثنار تفتى جائحة كورونا على الممارسات المهنية المعتمد فى إعداد التقارير المالية لمنشآت الأعمال وبيات تللك الأثنار على نتائج أعمالها وبل و وعلى إمكانية استمر اريتها،

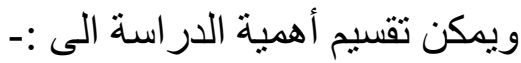




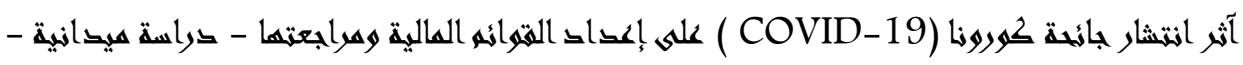
د/ وليد سهير عبد العظيه الجبلمى

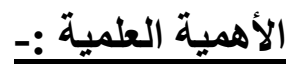

تتبع أهمية الدر اسة العلمية من حداثة فية موضوعها المتمنل فى معرفة أثر تفثى جائحة

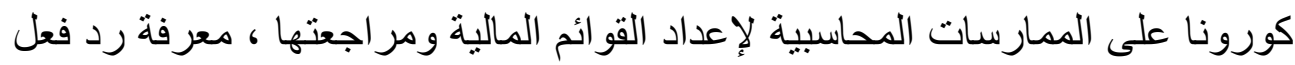

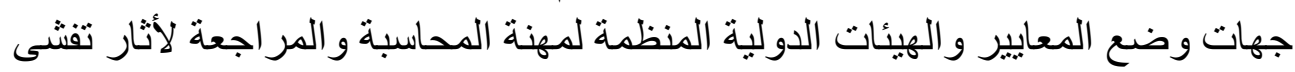
جائحة كورونا على نتائج أعمال الثركات بل وفئل وعلى استمر اريتها .

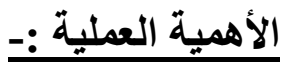

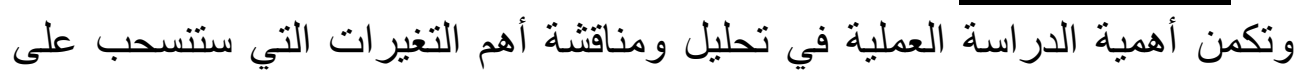

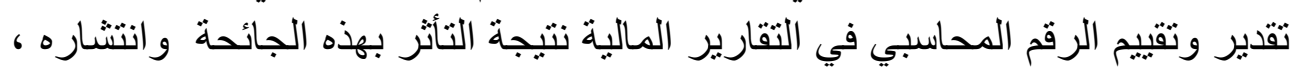
وبيان نطاق الإفصاح المحاسبي الذي يدعم من قدرة المستخدمين ويعزز من فهرهم و إدر اكهم لآثار ها على أداء الثركات الحالي و المستقبلي وكيفية مر اجعة تللك النتائج

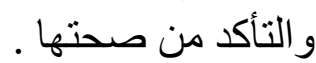

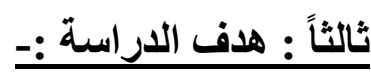

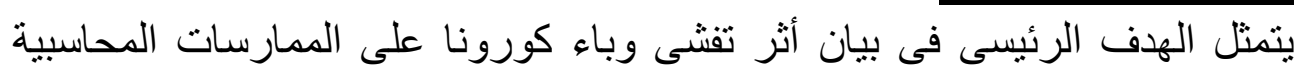

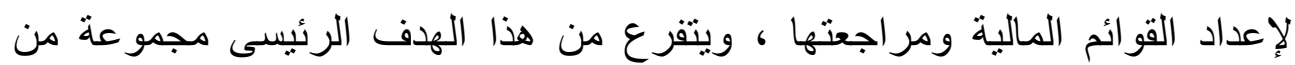

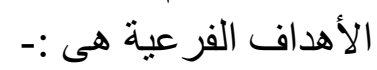

ل التعريف بجائحة كورونا، و أهم الآثار الاقتصادية التي أحدثتها والمتوقع حدوثها

$$
\text { مستقبلا. }
$$

ل بيان أثز الجائحة على الممارسات المحاسبية لإعداد التقارير المالية و أهم مجالات

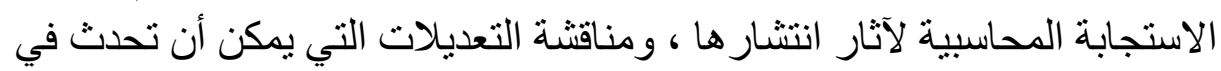

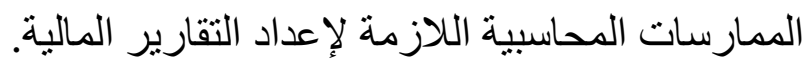

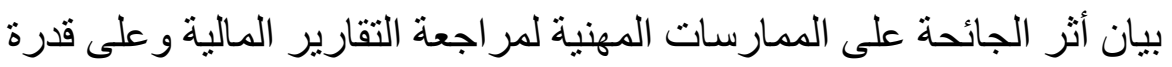

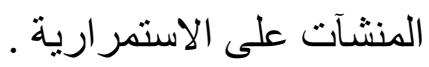

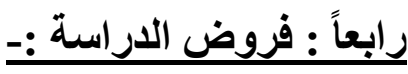
فى ضوء طبيعة مشكلة الدر اسة و أهدافها و أهميتها يمكن صياغة فروضي فرض الدر اسة كما يلى : 


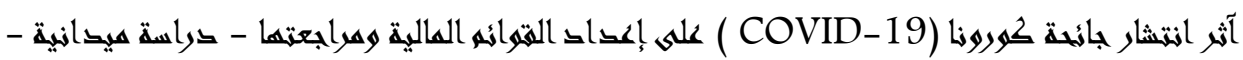
د/ وليد سهير عبد العظيه الجبلمى

ا ا الفرض الأول :-_ لا توجد علاقة ذات دلالة إحصائية بين تأثير تفشى جائحة

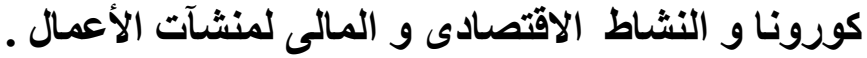

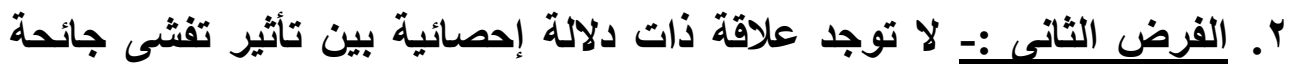

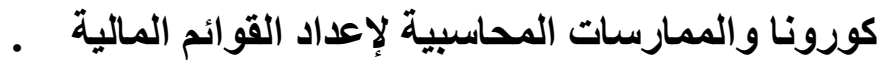

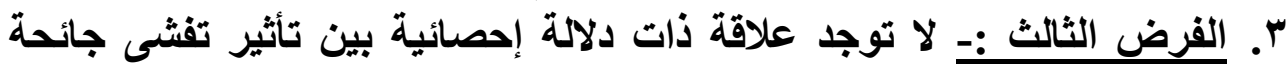

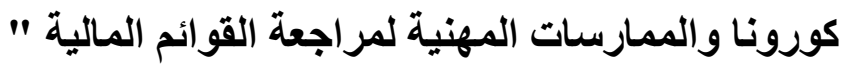
خامساً : أسلوب الاراسة :-. المنهج الاستدلالى :- لـ لبناء الإطار النظري للارساسة وذللك من خلال استقراء

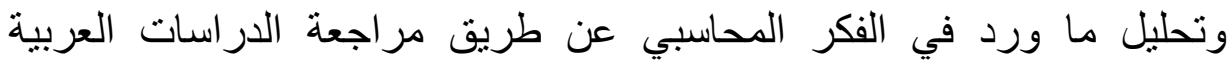

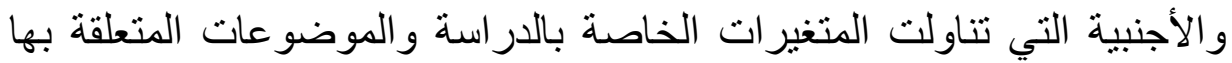

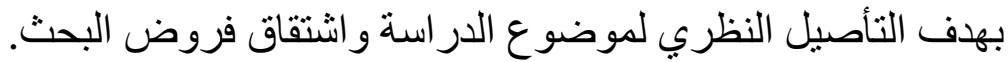

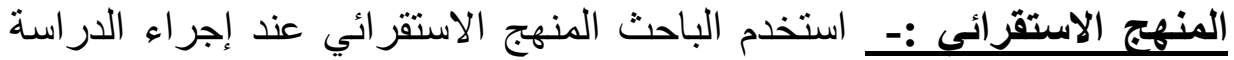

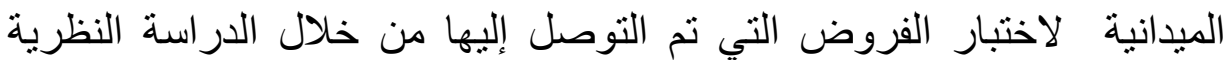

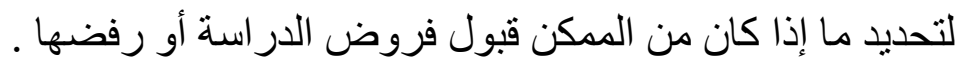

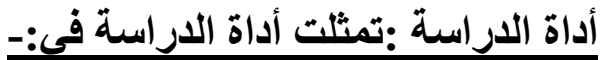

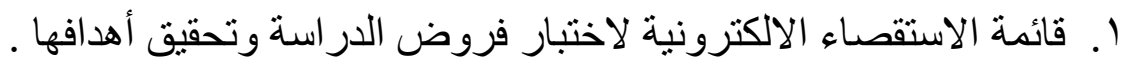

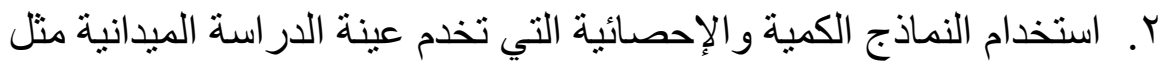

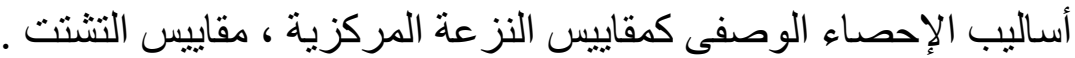

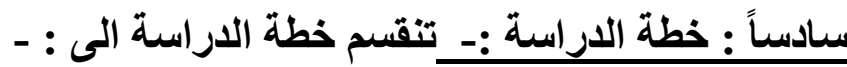

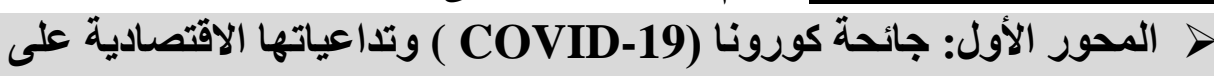

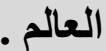
المحور الثانى : تداعيات أزمة كرونا COVID-19 على الممارسات المحاسبية لإعداد القوائم المالية > المحور الثالث :- ت تداعيات أزمة كرونا COVID-19 على مراجعة القوائم

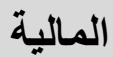




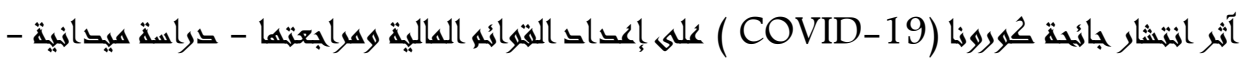
د/ وليد سهير عبد العظيه الجبلمى

\section{خ المحور الرابع :- الدراسة الميدانية .}

\section{المحور الأول: جائحة كورونا (COVID-19 ) وتداعياتها الاقتصادية على العالم}

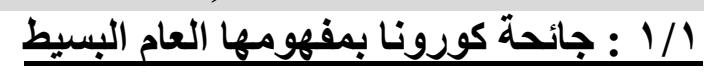
فيروس كورونا هي فصيلة كبيرة من فيروسات التي قد تسبب المرض للحيوان و الإنسان .ومن المعروف أن عدداً من فيروسات كورونا تسبب لدى البشر حالات عدوى الجهاز التنفسي التي تثراوح حدتها من نزلات البرد الثائعة إلى الأمراض الأشد وخامة منل متلازمة الثرق الأوسط التتفسية والمتلازمة التنفسية الحادة الوخيمة (السارس). ويسبب جائحة كورونا المُكتشف مؤخراً مرض جائحة كورونا كوفيدــ 1 ا.

( Reuven.S:2020)

يمكن أن يصاب الأشخاص بعدوى مرض كوفيدو 1 عن طريق الأشخاص الآخرين المصابين بالجائحة. ويمكن للمرض أن ينتل من شخص إلى شخص عن طريق القُطيرات الصغيرة التي تتناثر من الأنف أو الفم عندما بسعل الثخص المصاب بمرض كوفيد_9 أو يعطس. وتتساقط هذه القُطيرات على الأشياء و الأسطح المحيطة بالشخص. ويمكن حينها أن يصاب الأشخاص الآخرون بمرض كوفيد-9 اعند ملامستهم لهذه الأشباء أو الأسطح ثم لمس عينيهم أو أنفهم أو فمهم. كما بمكن أن يصاب الأشخاص بمرض كوفيدهو إذا تتفسوا القُطيرات التي تخرج من الثخص المصاب بالمرض مع سعاله أو زفيره ـولذا فمن الأهمية بمكان الابتعاد عن الثخص المريض بمسافة تزيد على مثر واحد ، و تتمثل الأعراض الأكثر شيوعاً لمرض كوفيد-9 ا في الحمى والإرهاق و السعال الجاف. وقد بعاني بعض المرضى من الآلام و الأوجاع، أو احتقان الأنف، أو الرشح، أو ألم الحلق، أو الإسهال .و عادة ما تكون هذه الأعر اض خفيفة وتبدأ تدريجياً. ويصاب بعض الناس بالعدوى دون أن تظهر عليهم أي أعر اض ودون أن يشعروا بالمرض. ويتعافى معظم الأشخاص (نحو . ^ـ\%) من المرض دون الحاجة إلى علاج خاص. وتشتد حدة المرض لدى شخص و احد ثقريباً من كل 7 أشخاص بصابون بعدوى كوفيدو 1 حيث يعانون من صعوبة التفس . وتزداد احتمالات إصابة المسنين والأشخاص المصابين بمشكلات طبية أساسية مثل 


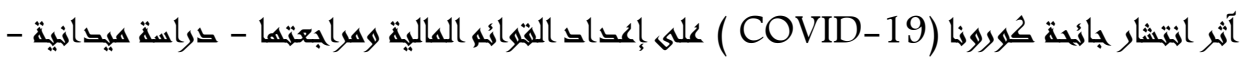
د/ وليخ سمير عبط العظيه الجبلى

ارتفاع ضغط الدم أو أمر اض القلب أو داء السكري، بأمر اض وخيمة. وقد توفى نحو

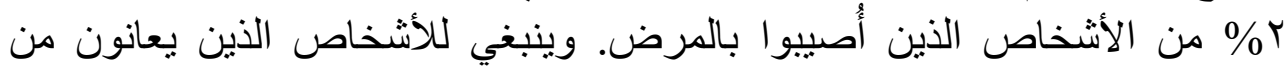
الحمى و السعال وصعوبة التفس التماس الرعاية الطئية الطبية.

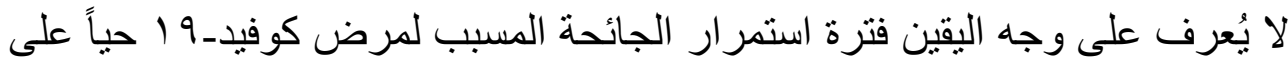

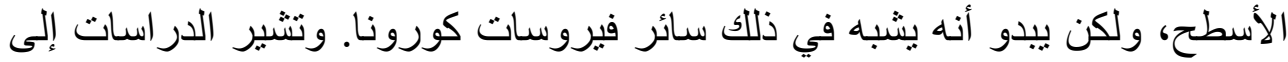

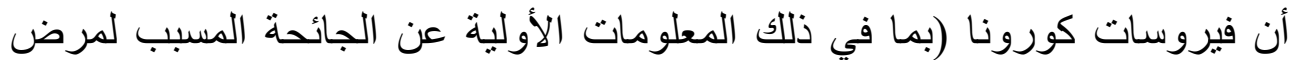

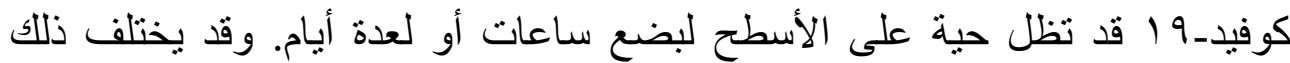
باختلاف الظروف (مثل نوع السطح ودرجة الحرارة أو الرطوبة البيئية)..

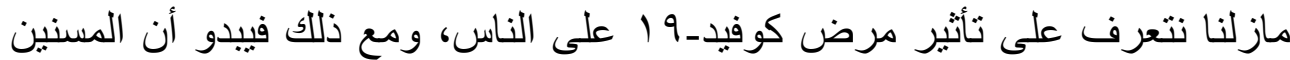

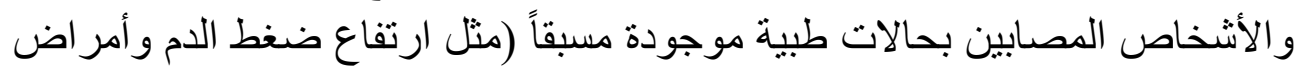
القلب وداء السكري) يصابون بمرض وخيم أكثر من غير هم.

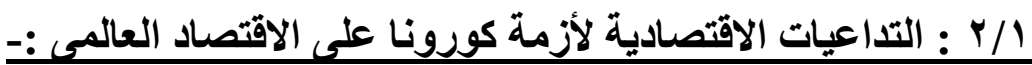

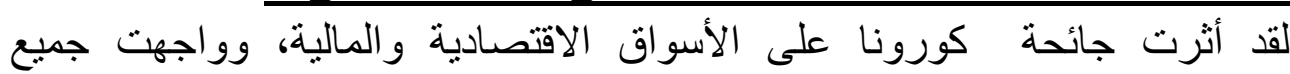
الصناعات تقريبا تحديات مرتبطة بالظروف الاقتصادية الناتجة عن جهود معالجتها.

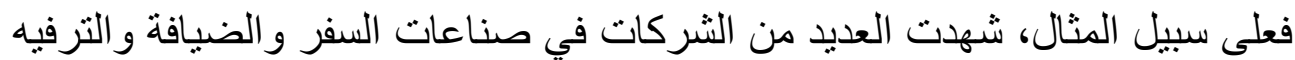

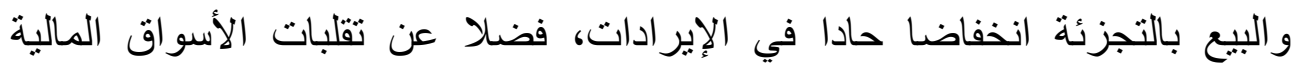

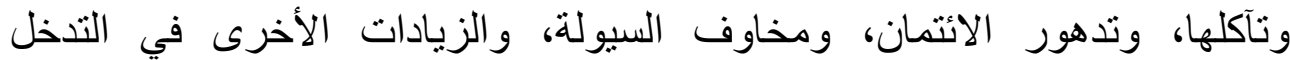

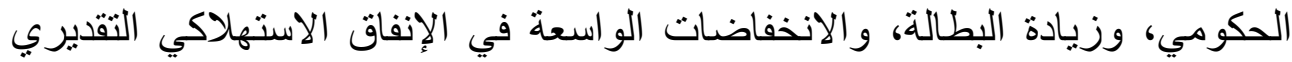

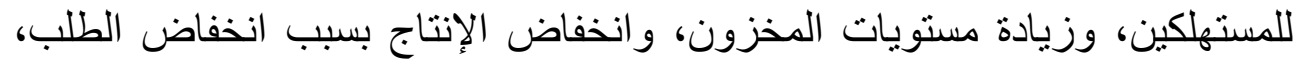

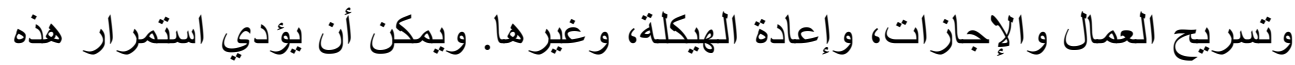

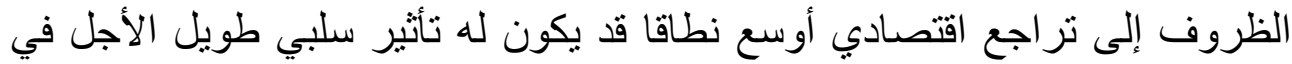

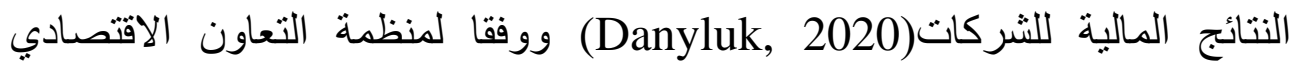

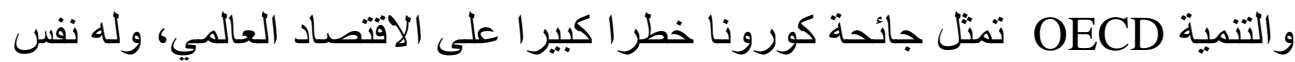

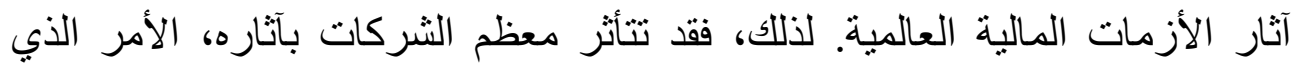
يفرض على كل شركة إجراء إعادة تقييم لأنشطتها وممارساتها مع مر اعاة الحقائق 


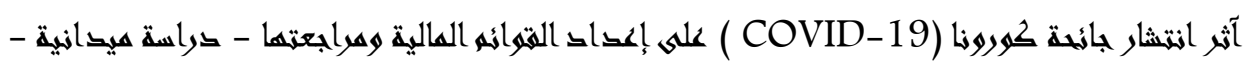
د/ وليد سهير عبد العظيه الجبلمى

و الظروف و الخصوصية لكل شركة. فمع انتثاره في جميع أنحاء العالم، ستحتاج

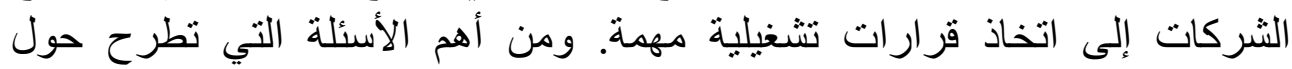
التداعيات الاقتصادية للثركات في ظل هذه الأزمة يأني (Richter, 2020) -: ( Juha:2020) هل تعتمد الثركة بشكل مباشر أو غير مباشر على سلسلة التوريد من المناطق

المتضررة؛

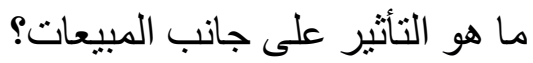

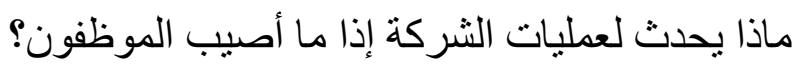

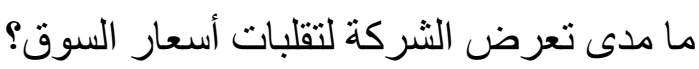

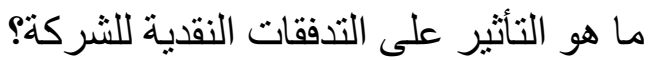

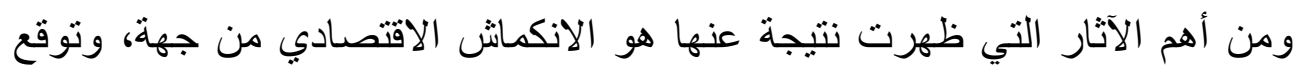

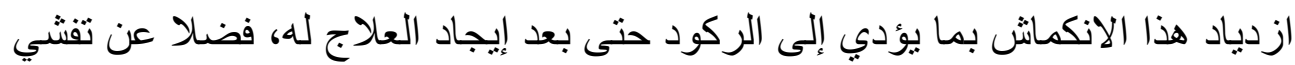

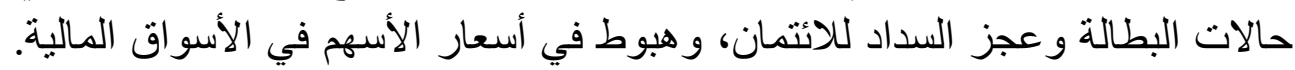

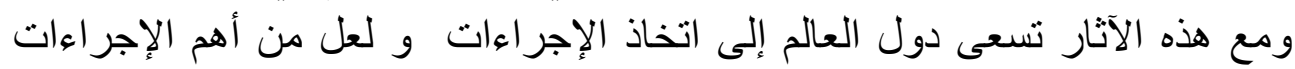

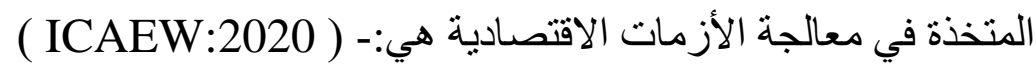

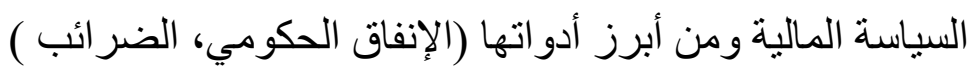

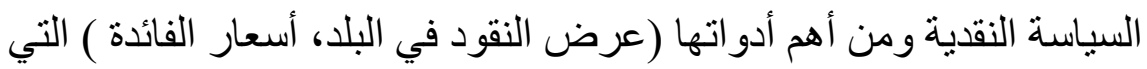
من شأنها أن تحد من تأثيره.

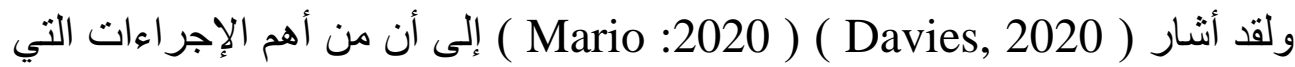

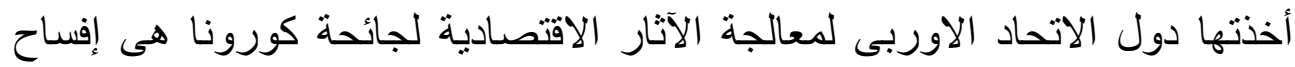

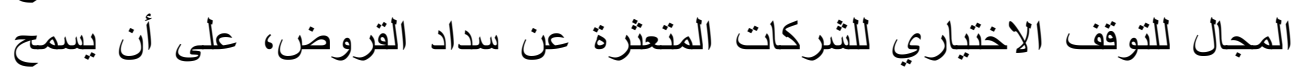

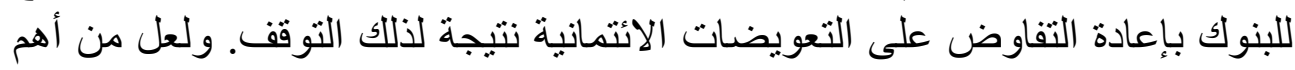

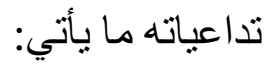
\$ أنطاع الإنتاج.

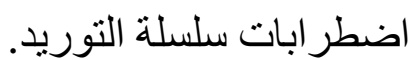




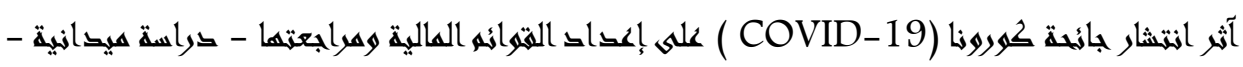
د/ وليد سهير عبد العظيه الجبلمى

$$
\begin{aligned}
& \text { انخفاض في المبيعات أو الأرباح أو الإنتاجية. } \\
& \text { إغلاق الثركات و المخازن. } \\
& \text { التأخر في توسعات الأعمال المخطط لها. لأنات } \\
& \text { عدم القدرة على زيادة التمويل. } \\
& \text { زيادة التقلبات في قيمة الأدوات المالية. }
\end{aligned}
$$

\# و غير ها من الأنشطة الترفيهية. الآثار العامة المنز ايدة لجائحة كورونا نتيجة لانتهة لتأثنير ها السلبي في الاقتصاد

$$
\text { العالمي والأسواق المالية الرئيسة. }
$$

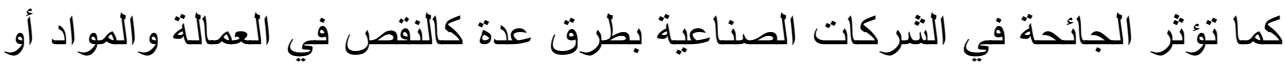

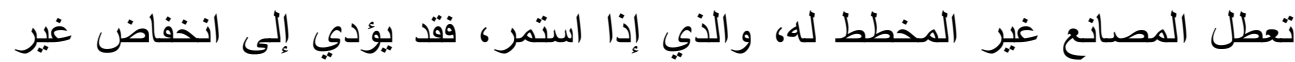

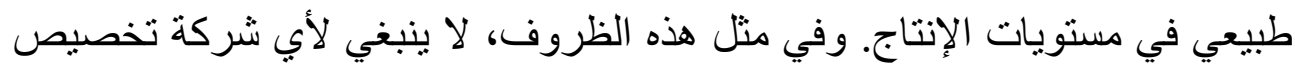

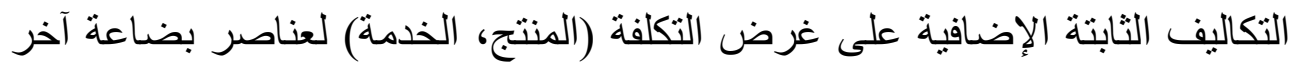

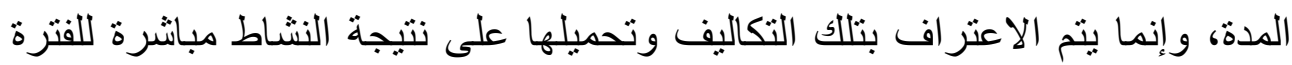

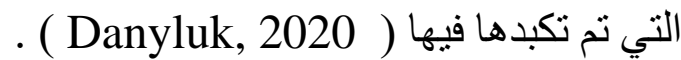
المحور الثانى : تداعيات أزمة كورونا COVID-19 على الممارسات المحاسبية الإعداد القوائم المالية

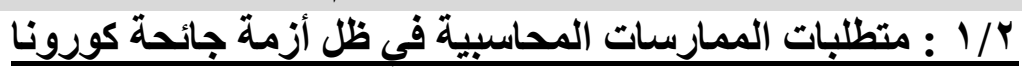

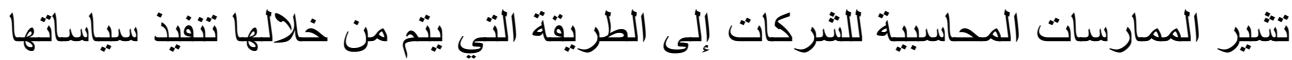

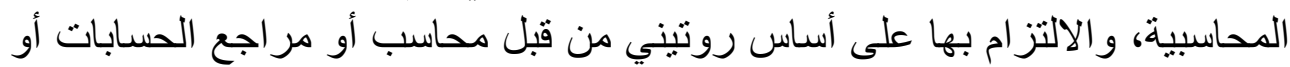

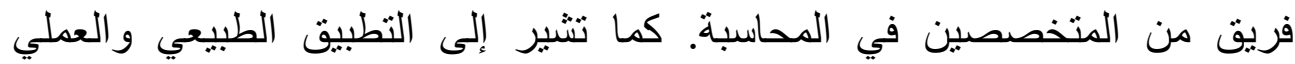
لسياسات المحاسبة أو المر اجعة التي تحدث داخل الثركة. وتهدف إلى تطبيق المبادئ التوجيهية و السياسات المحاسبية للثركة. ومع التفثي السريع لجائحة كورونا، فرضت

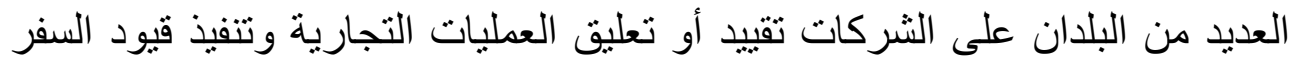
وتدابير الحجر الصحي. وقد أدت هذه التدابير والسياسات إلى تعطيل أنشطتها. وتظهر 


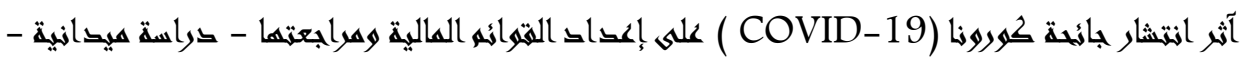
د/ وليق سمير عبد العظيه الجبلى

الاضطر ابات بشكل أكثر وضوحا مع بعض الصناعات مثل السياحة و الضيافة و النقل

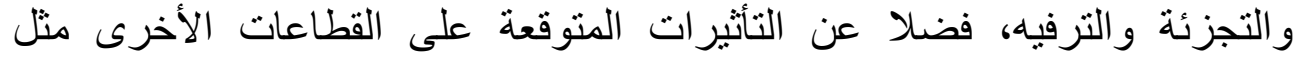

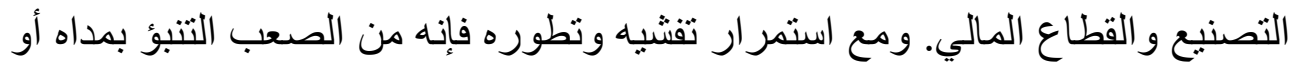

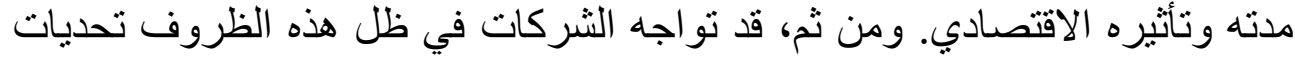

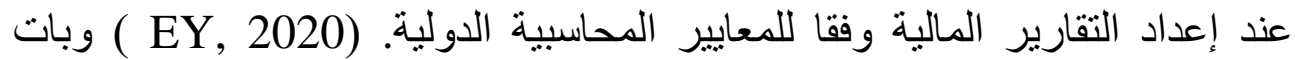

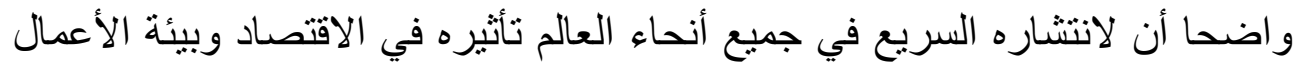

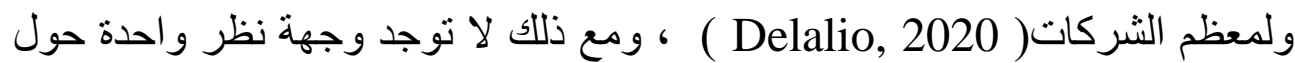
كيفية تطوره وتأثيره على الاقتصاد ، لذا فإن عدم وجود مثل هذا الاتفاق في وجهات

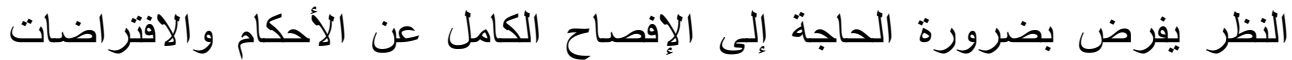

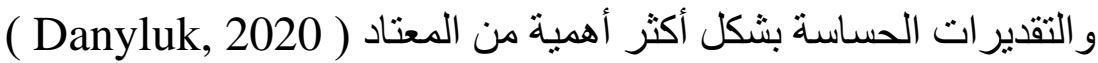
وقد يكون للعو اقب الاقتصادية الناتجة عن هذا الجائحة نفس الإجراءات التئ من التي تتخذها الحكومات و القطاع الخاص كاستجابة لتفثي الأمر اض و الكوارث (Richter, 2020 ) وغيرها من الأزمات ، وفي منشور صادر عن (EY, 2017) ذكر فيه أهم مجالات الاستجابة المحاسبية التي يجب مر اعاتها عند معالجة آثار الكوارث ماثل الطبيعية،

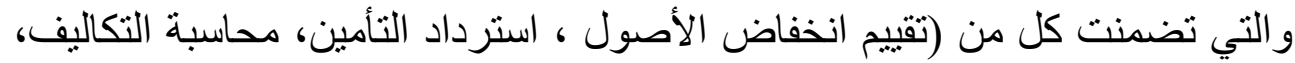

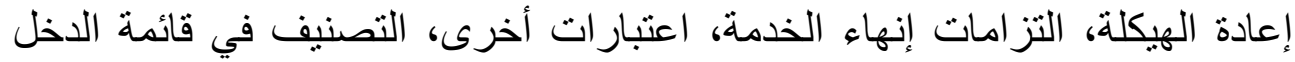

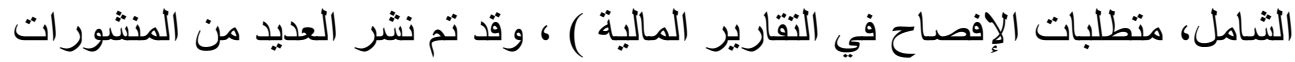

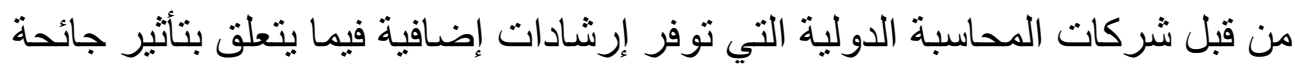
كورونا على التقارير المالية (IATA, 2020) .ومن هذه المنشورات على سبيل المثنال لا الحصر ما يأتي:

( PWC )

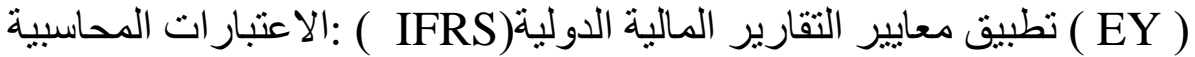
لتفشي جائحة كورونا. الآثار المحاسبية لجائحة كورونا . (KPMG ) 


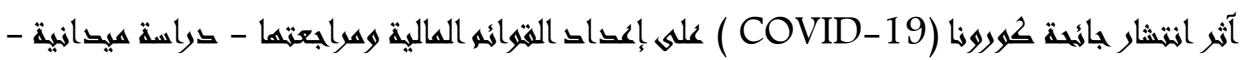
د/ وليخ سمير عمب العظيه الجبلمى

(Deloitte) المتعلقة بجائحة كورونا.

هذا إلى جانب العديد من المنشورات التي تناولت الآثار التي يمكن أن يخلفها على التى

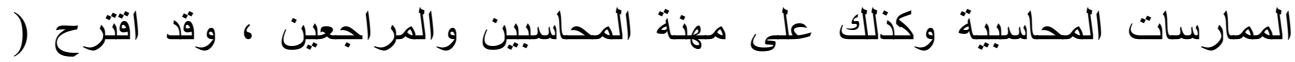
) ( Delalio, 2020 و هذه الطرق هي:-

ل الاستعانة بالحوسبة السحابية في تشغيل البر امج المحاسبية للشركة.

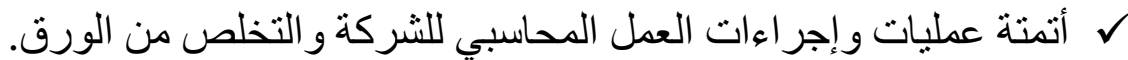

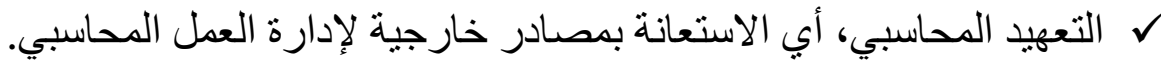
ل إعادة ترتيب وتصفية الأعمال و التركيز على الأنشطة الأكثر قيمة في الاستثمار.

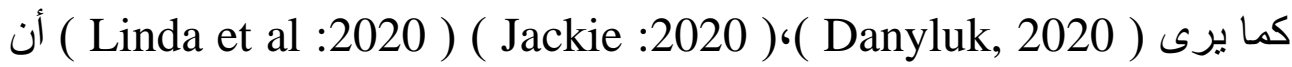
من أهم الموضوعات التي ستتطلب استجابة محاسبية لمعالجتها في ظل انتشار

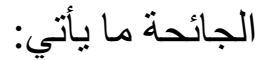

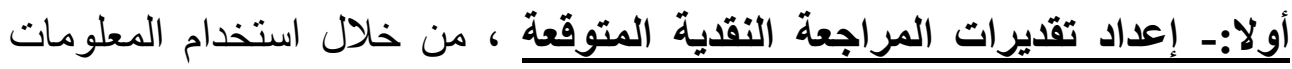

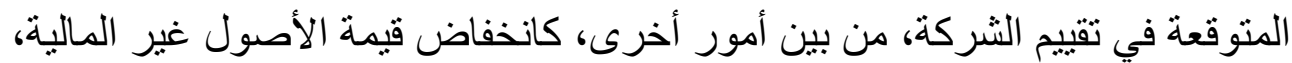

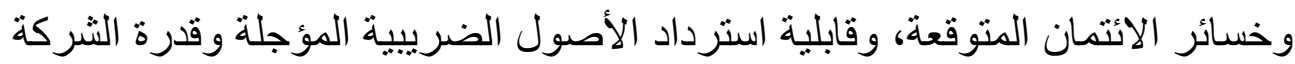
على الاستمر ار. كما اشتملت التعقيدات المرتبطة بإعداد معلومات فالتهات تطلعية (مستقبلية

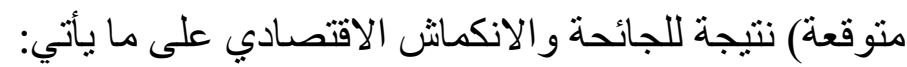

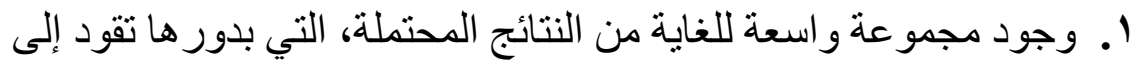

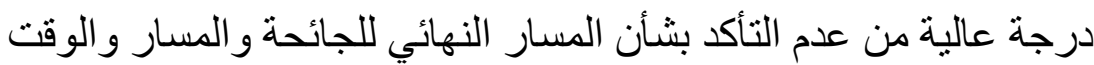

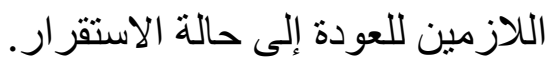
ץ. اعتماد التأثير الاقتصادي المصاحب للجائحة بشكل كبير على المتغير ات التي التي يصعب التنبؤ بها.

r. ضرورة ترجمة كل شركة لتأثير ات تللك الظروف بمجمو عها إلى تقدير ات

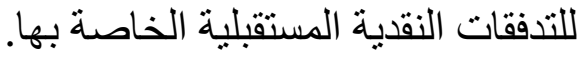




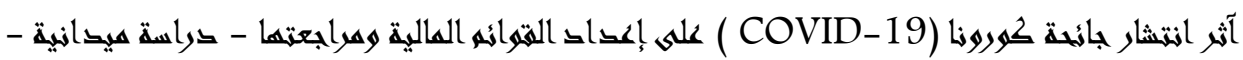
د/ وليد سهير عبد العظيه الجبلمى

ثانيا:- قابلية استرداد الأصول وانخفاض قيمتها، إذ غالبا ما بتطلب اختبار انخفاض قيمة الأصول غير المالية تحسين وتطوير توقعات التدفقات النقدية التي تخضع للشكو ك الكبيرة. ثالثا:ـ المحاسبة عن الأصول الماليةة، إذ أصبح هناك انخفاضا حادا في القيمة العادلة للعديد من الأصول المالية، لا سيما الأوراق المالبة. وبالمثل فقد تأثرت قدرة المدينين على الامتثال لثروط القروض و الأدو ات المماثلة بشكل سلبي. وستحتاج الثركات إلى النظر بعناية في متطلبات القياس وتقدير خسائر انخفاض القيمة المناسبة وتطبيقها رابعا:ـ تعديلاث العقود، إذ من المتوقع أن تؤدي التخير ات في النشاط الاقتصادي التي ماتي سببها الجائحة إلى قيام العديد من الشركات بإعادة التفاوض على شروط العقود. منل بـ العقود المبرمة مع العملاء، وترتيبات التعويض مع الموظفين، و الإيجار ات، وشروط العديد من الأصول و المطلوبات المالية، كما ستحتاج الثركات إلى التأكد من تطبيق المتطلبات المتعلقة بمعايير التقارير المالية الدولية. خامسا:- الأحداث بعد اتتهاء فترة إعداد التقاريز المالبة، فمن الصعب على الثركة

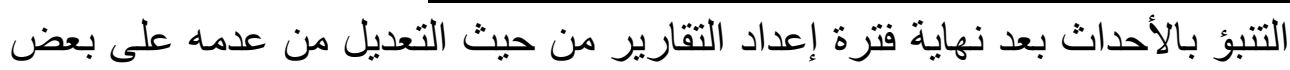
قيم بنودها في ظل التقلبات الكبيرة والمستمرة للسوق العالمي كما هو الحال هع الإعلانات عن الحوافز والقيود الحكومية ورد فعل سوق الأسهم اليومي على المعلومات الجديدة. ، ويرى ( EY, 2020 ) أن الاستجابة المحاسبية في ظل انتشار الجائحة يجب أن تتضمن كلا من :- الأحداث بعد الفترة المشمولة بالتقرير الاستمرارية ـ قياس القيمة العادلة - تقييم الخسائر الائتمانية المتوقعة ـ انخفاض الأصول - متطلبات الإفصاح عن التقارير المالية الأخرى - تقدير ات محاسبية أخرى.

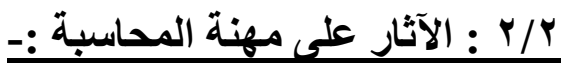

لجائحة كورونا القدرة على إحداث تغييرات كبيرة في أسلوب عمل المحاسبين المتخصصين بإعداد التقارير المالية للثركات، فضلا عن مدققي الحسابات الخارجيين على حد سواء (Radigan, 2020) وفي ظل انتشار ها فإن أغلب الثركات بدأت تنتهج مع موظفيها أسلوب العمل المنزلي، بما في ذلك شركات المحاسبة والتدقيق، إذ 


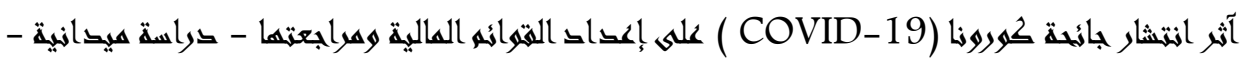
د/ وليخ سمير عمب العظيه الجبلمى

أشارت شركة Deloitte إلى ضرورة أن يهتم المحاسبون بحماية صحتهم و أعمالهم

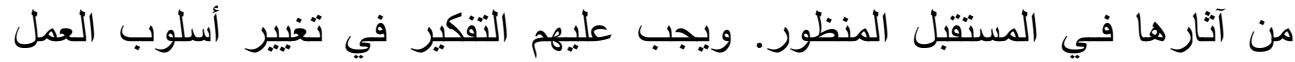

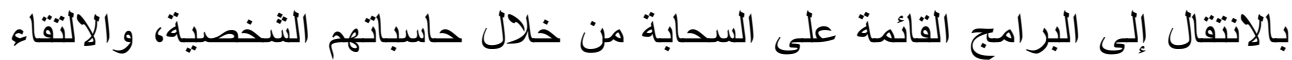

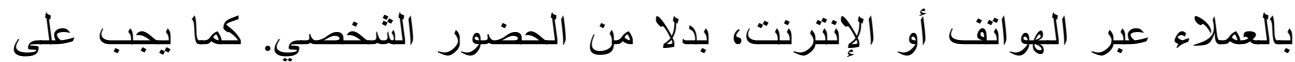

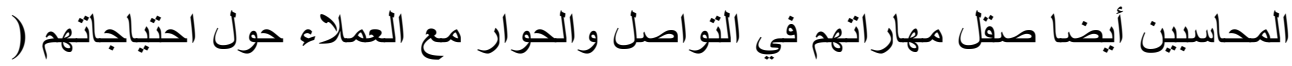

( Moyer, 2020

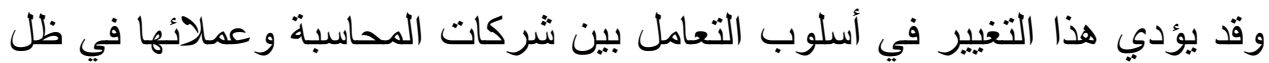
هذه الجائحة إلى العديد من الآثار السلبية منها؛ فقدان العديد من المحاسبين عملهم،

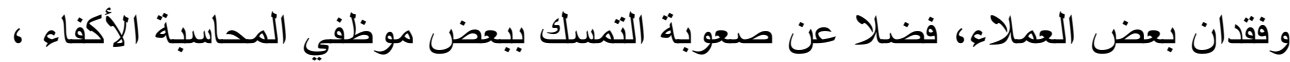

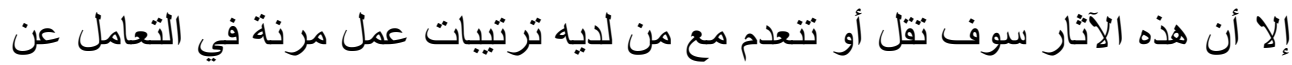

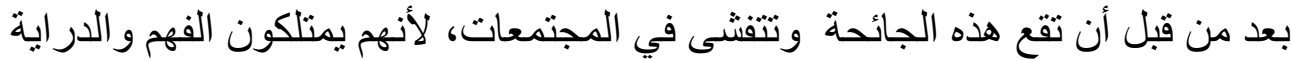

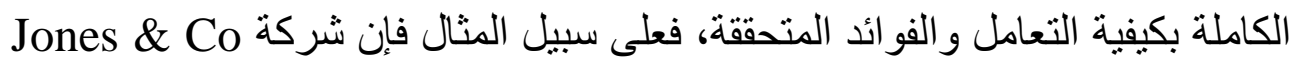
الر ائدة في مجال المحاسبة، استفادت من عملها على مدار ؟ ؟ عاما في مجال الأعمال

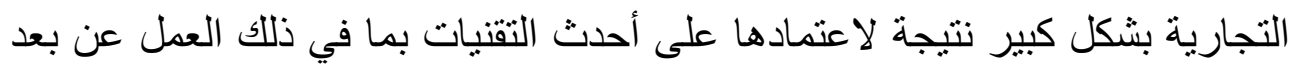
( Moyer, 2020) ، وبصرف النظر عن هذه الاحتياطات التي يمكن أن تتخذ

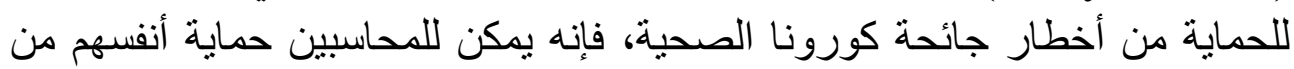

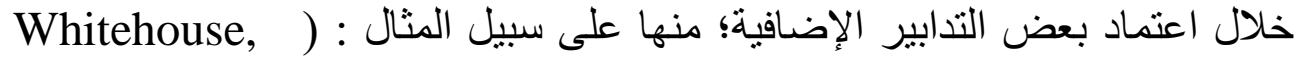

أ- يجب على شركات المحاسبة السماح بالوصول إلى التطبيقات و البوابات المناسبة

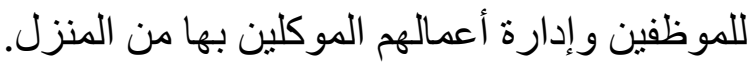

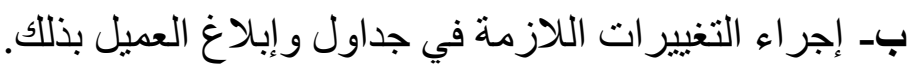
ج- اعتماد البيانات الرقمية ومنصات مشاركة الملفات اللازمة للعميل لتجنب استخدام

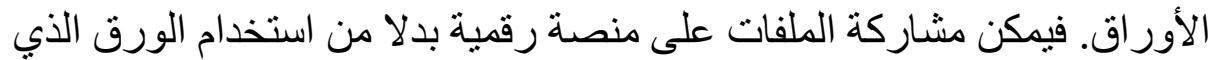

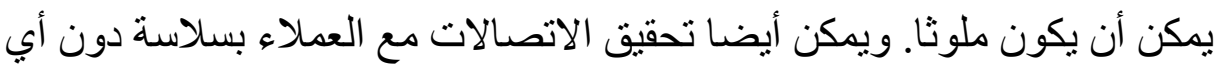
خسارة في الإنتاجية. 


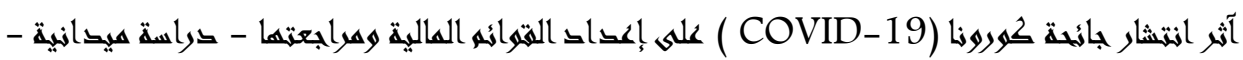
د/ وليد سهير عبد العظيه الجبلمى

دـ تجنب إجر اء الاجتماعات أو حضور ها لفترة من الوقت وتبني مؤتمر ات الفيديو.

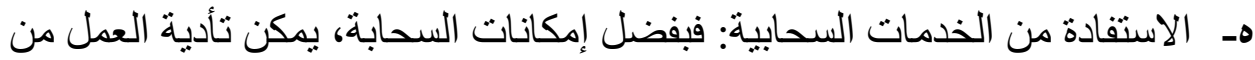

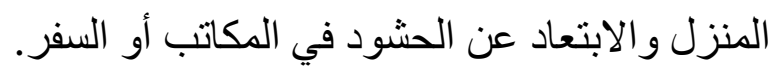

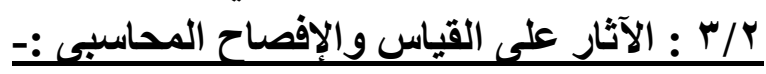

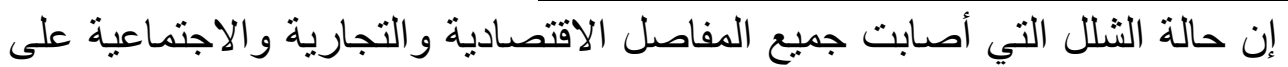

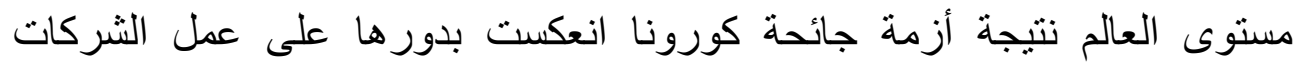

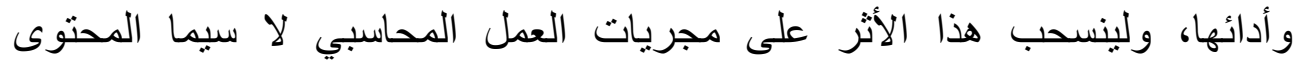
المعلوماتي للتقارير المالية ، ويشير ( Davies, 2020 ) إلى أن النظام المصرفي

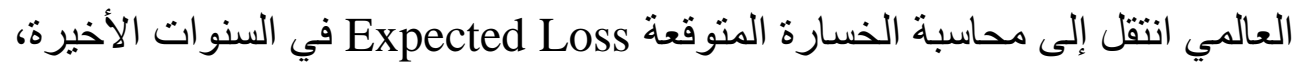
Incurred بسبب ردة الفعل السياسية ضد المعايير القائمة على الخسائر المتكبدة Losses

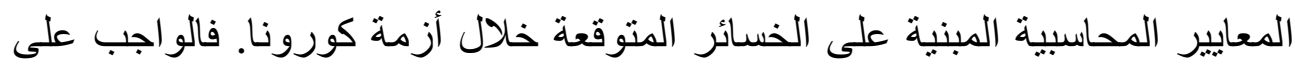

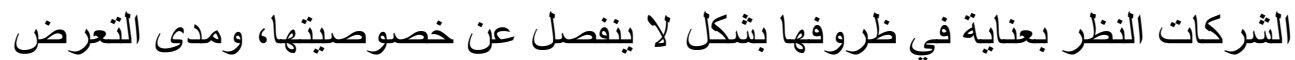

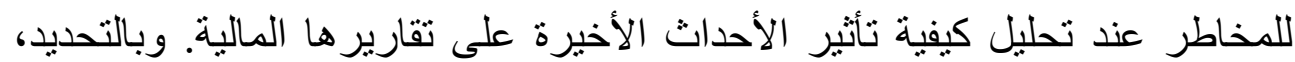
ستحتاج عمليات الإفصاح ضمن تقاريرها إلى نقل الآثار الجوهرية للجائحة

( Danyluk, 2020)

و هو ما دفع المعهد الأمريكي للمحاسبين القانونيين المعتمدين ( AICPA ) للطلب من

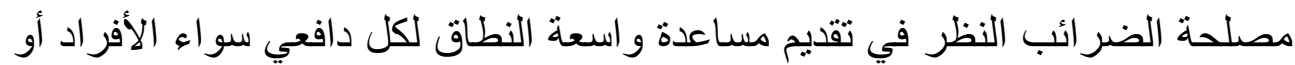
الثركات بسبب انتشار جائحة كورونا، وقد أكدت مصلحة الضرائب في في الولائيات

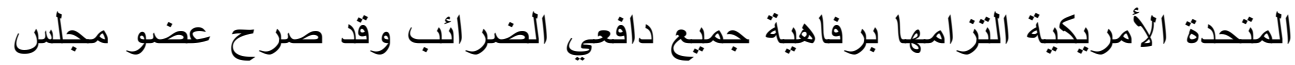

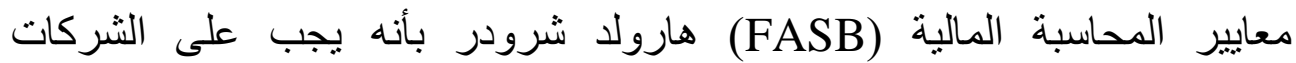

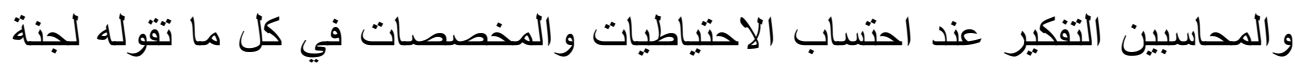

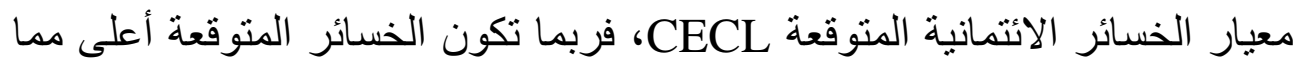
كانت عليه قبل شهر أو شهرين عندما لم نكن نخطط لإغلاق كل شيء الإئ عالمية. 


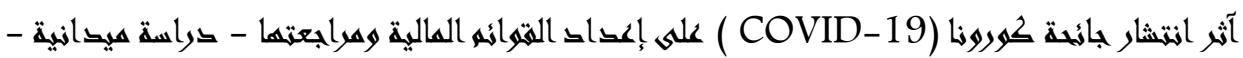
د/ وليق سمير عبد العظيه الجبلى

ويؤكد (KPMG, 2020) على ضرورة الإفصاح عن المعلومات التي تمكن

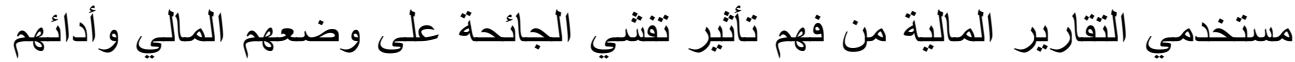
حتى وقت إصدار البيانات المصرح بها. وبالر غم من عدم وجود الكثير من الإرشادات

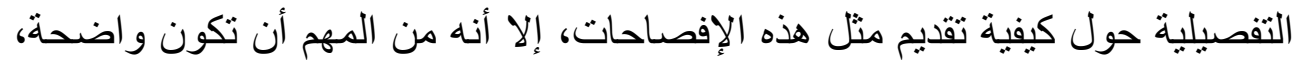
و على الثركات أن تكون حذرة لتجنب تقديم إفصاحات بطرق بمكن أن تكون مضلاهلة

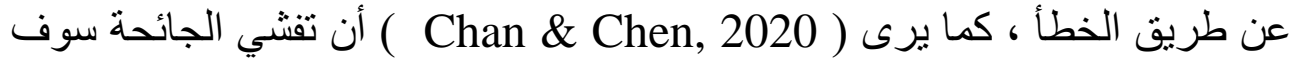
يكون له الأثر الكبير في كل من الممارسات المحاسبية الآتية: (تقييم انخفاض Onerous الأصول، قياس القيمة العادلة، الأحكام المحتملة للعقود المرهئل

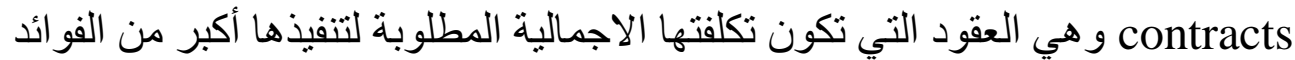

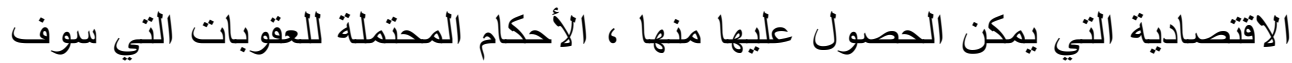

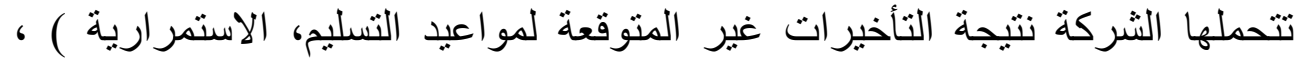

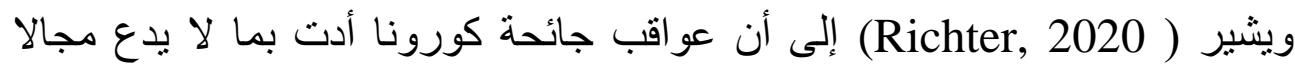

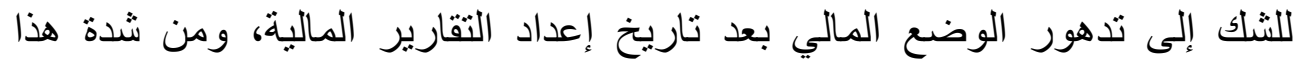

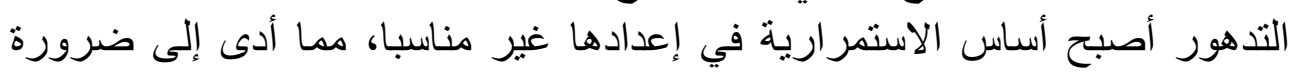

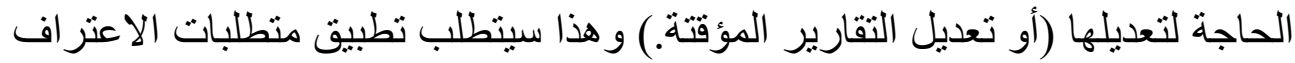

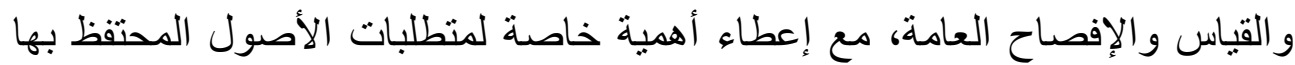

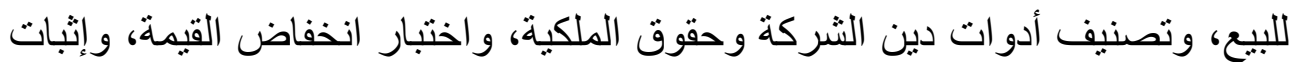
وقياس المخصصات و وغير ها.

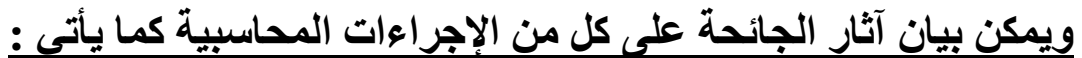

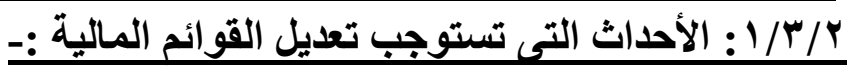

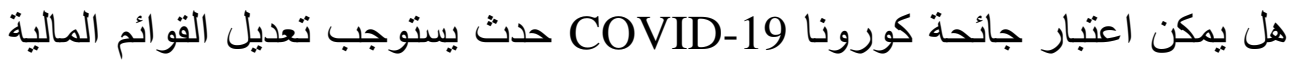

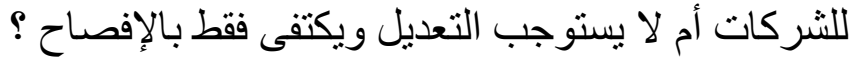

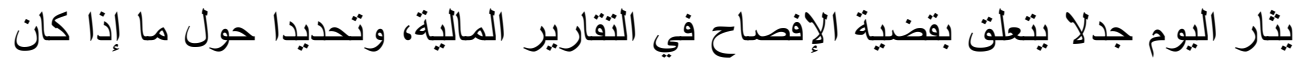

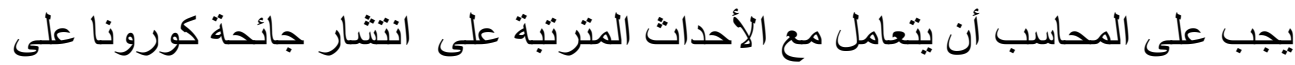
أنها أحداث لاحقة لإعداد القوائم المالية وفق معيار المحاسبة الدولي رقم • 1. الصادر 


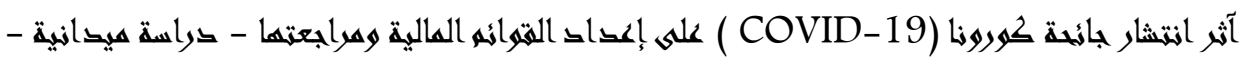
د/ وليق سمير عبد العظيه الجبلى

عن مجلس معايير المحاسبة الدولية (FASB) أم لا، ويميل الأغلبية إلى الرأي

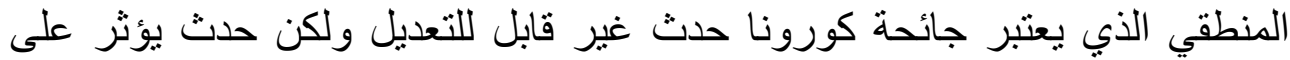

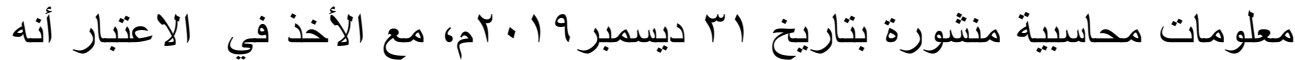

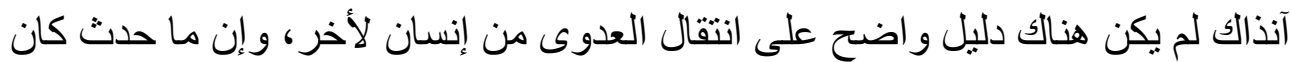

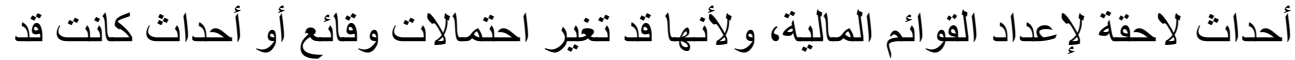

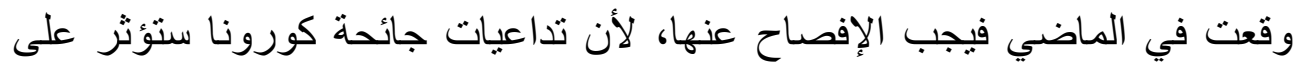

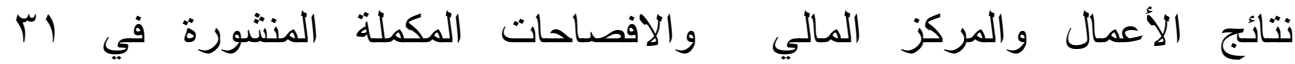

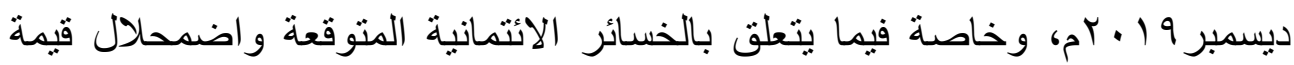

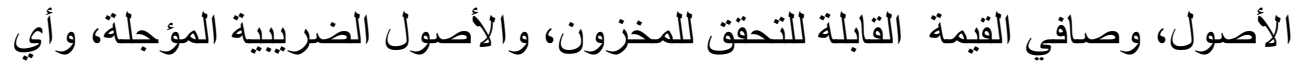

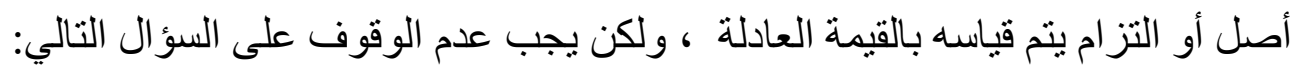

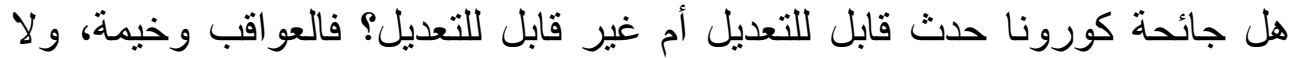

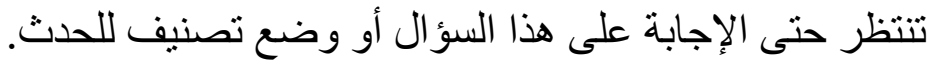

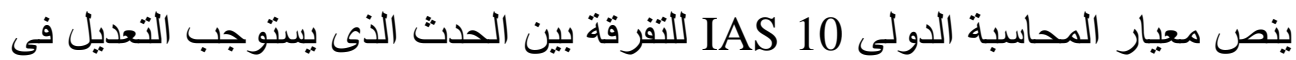
القوائم المالية والحدث الذى لا يستوجب التعديل :- ( PwC, 2020) (

( 2020

أــ الحدث الذى يستوجب التعديل : an adjusting event بأنه الحدث الذى وقع بعد تاريخ فترة التقرير ولكن يقدم دليل عن ظروف كانت موجودة قبل فترة التقرير

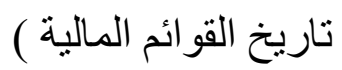
بـ كما أنه عرف الحدث الذى لا يستوجب التعديل non-adjusting event بأنه حدث يثير إلى ظروف نشأت بعد تاريخ إعداد التقرير (تاريخ القو ائم المالية ) .

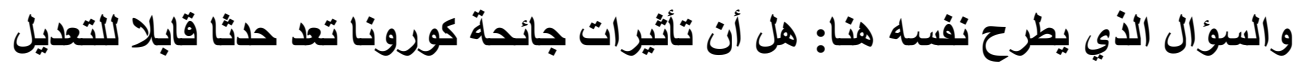

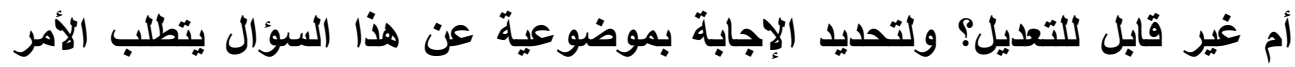

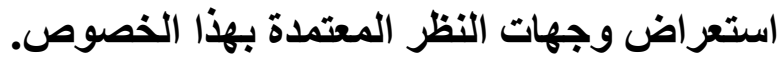

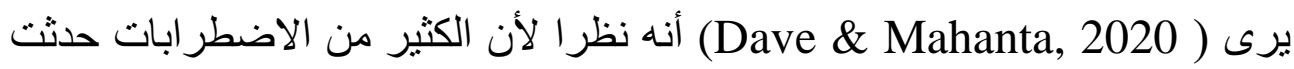

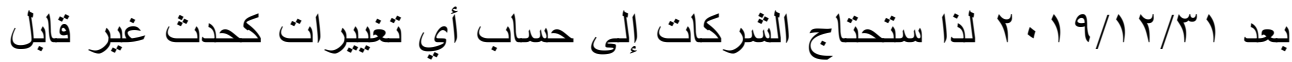




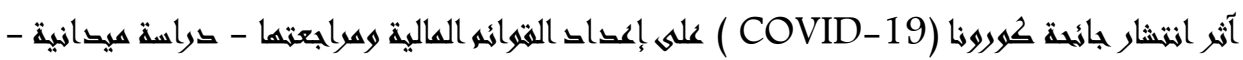
د/ وليخ سمير عمب العظيه الجبلى

للتعديل في الميز انية العمومية. مع هذا فأنه يجب على الثركة أن تفصح عن طبيعة

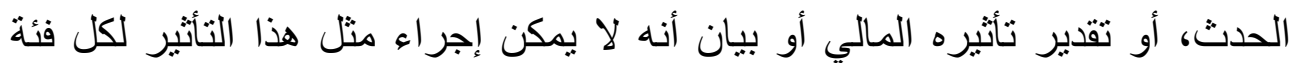

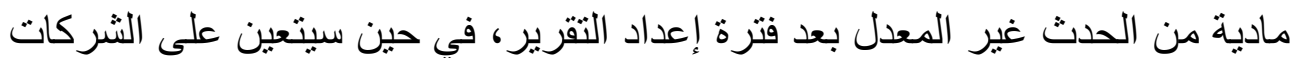

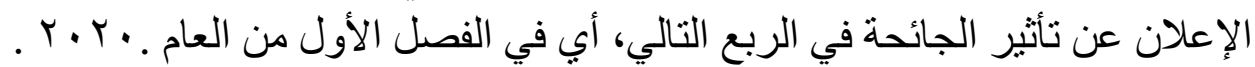

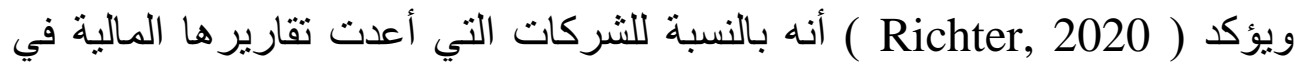

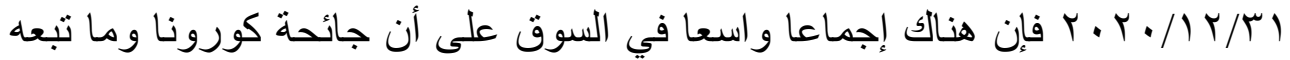

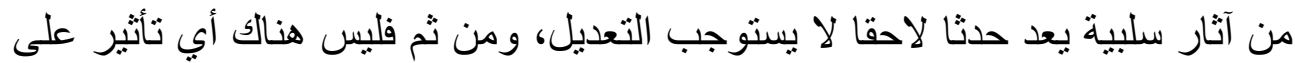

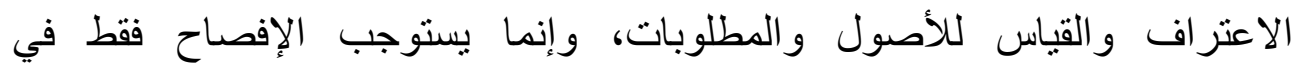

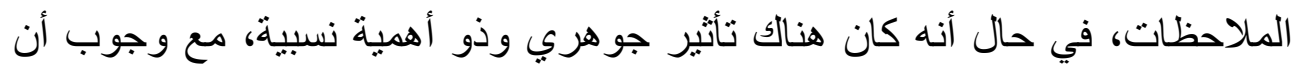
يتصف هذا الإفصاح بالثفافية ويشتمل على طبيعة الحدث (أي الآثار السلبية لجائحة

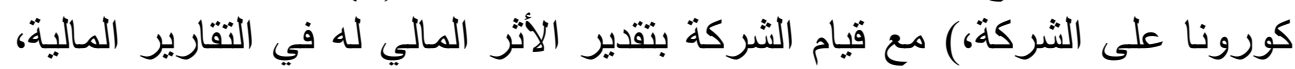
فعلى سبيل المثال، قد يتطلب الأمر الإفصاح عن الآثار المقدرة على الخفاض الخفاض قيمة

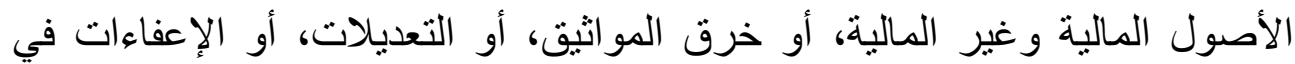

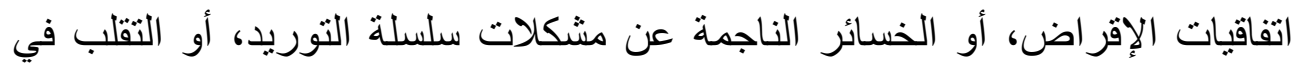

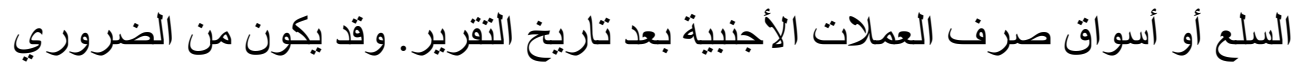
أيضا توفير معلومات حول التغير ات المحتملة في القيمة. ويضيف ( Danyluk, 2020 (أنه من المناسب بشكل عام اعتبار آثار تفشي الجائحة

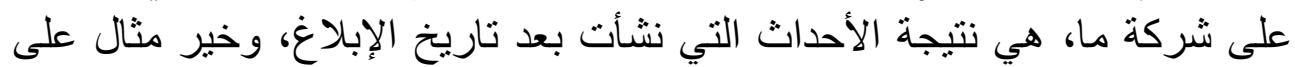

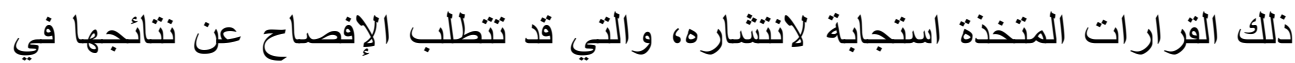

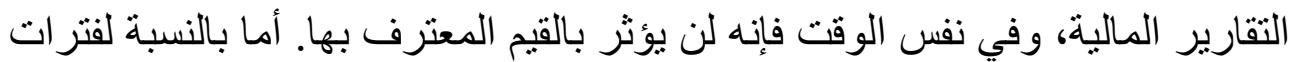

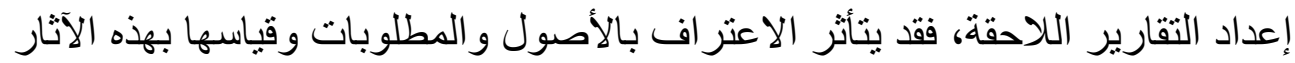

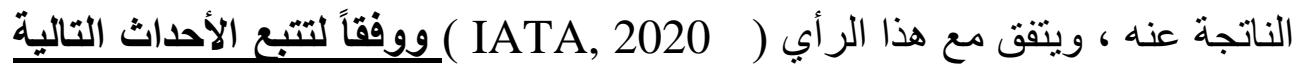

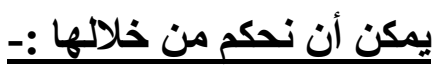




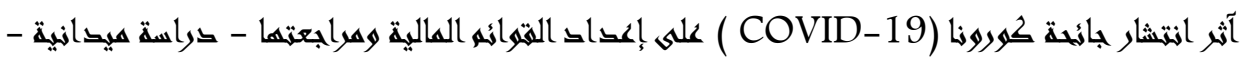
د/ وليق سمير عبد العظيه الجبلى

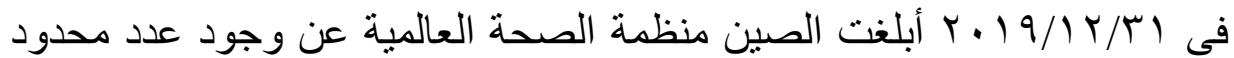

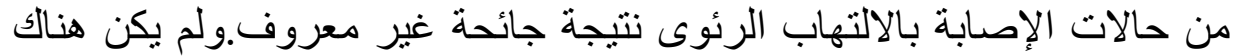
أي دليل صريح على انتقال العدوى من شخص لآخر في ذلالك التاريخ.

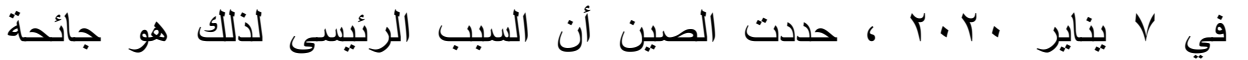

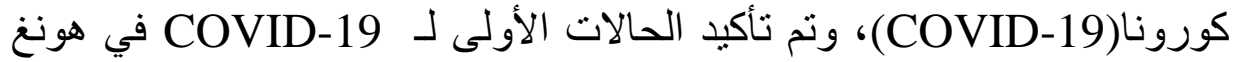

$$
\text { كونغ في سو يناير •r.r. }
$$

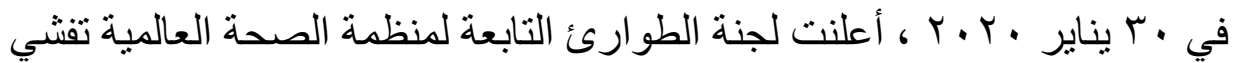

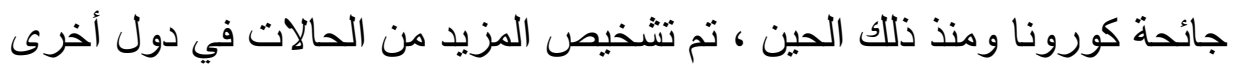
أيضًا.

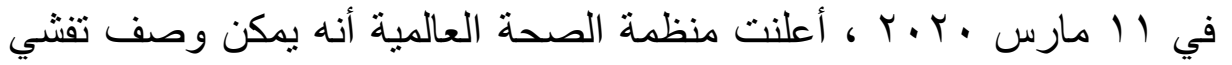

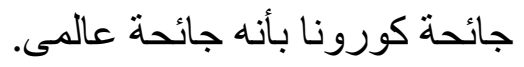
من خلال المعلومات السابقة يرى الباحث إن الجائحة لم تنتشر ولم يتوقئ عاند أحد أنها

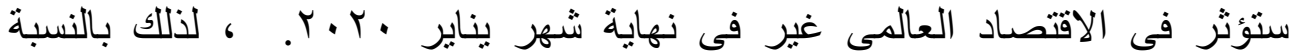

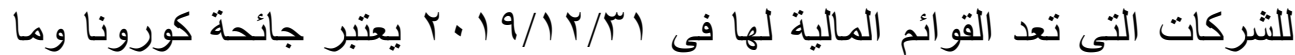
تبعها من آثار سلبية حدث لاحق لا يستوجب التعديل non-adjusting event و إنما

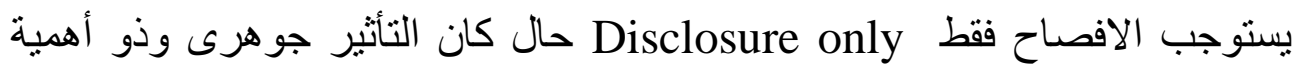
نسبية ، ويجب أن يكون هذا الافصاح يتسم بالثفافية ويشمل طبيعة الحدث (الآثار

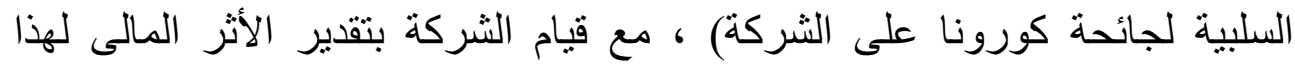

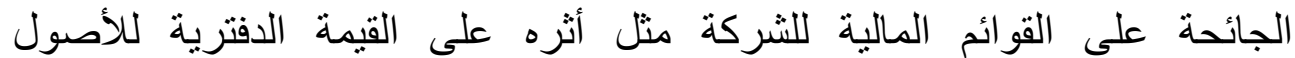
والالنزامات ، ما إذا كان من المتوقع حدوث اضمحلاتل لقيمة الأصول ، أو التأثير

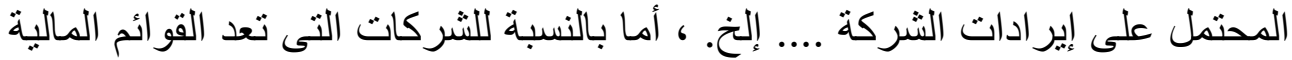

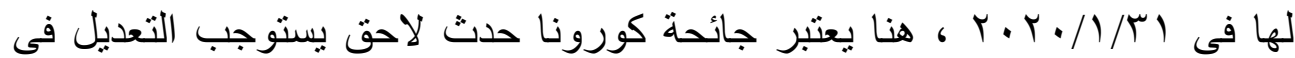

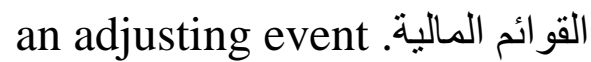
وبناء على ما سبق فإن نتائج تأثير جائحة كورونا على الوظيفة المحاسبية فيما يخص الأحداث اللاحقة يمكن تحديدها بما يأتي:- ( Hasam Fallahgaul 2020 ) 


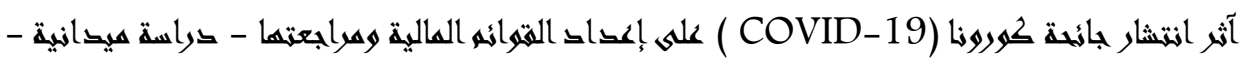
د/ وليد سهير عبد العظيه الجبلمى

() وظيفة القياس : تعامل نتائج تأثير ات جائحة كورونا في التقارير المالية في

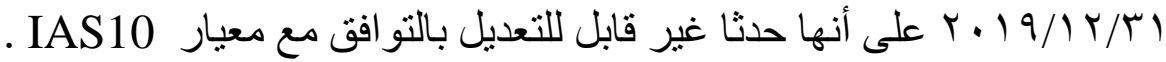
ب) وظيفة الإفصاح :بما أن نتائج تأثير جائحة كورونا هو حدث غير قابل للتعديل ولله تأثير جو هري، لذا فان على الثركة الإفصاح عن طبيعة الحدث وتقدير تأثيره الماللي.

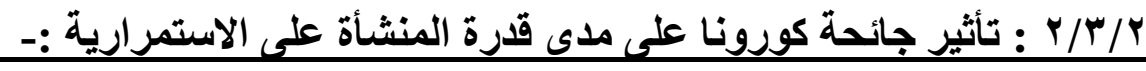
إن معيار المحاسبة الدولى IAS 1 فى فقرته رقم مب أشنار إلى أنه " عند إعداد القوائم المالية يجب على الإدارة إجراء تقويم لقدرة المنثأة على الاستمرار على أنها منشأة مستمرة . ويجب على المنشأة أن تعد القو ائم المالية على أساس الاستمر ارية ما لم تكن ألمن تنوى الإدارة أن تصفى المنشأة أو أن توقف الأعمال ، أو أنه ليس لديها بديلاً و اقعياً سوى أن تفعل ذلك ، و عندما تكون الإدارة على علم عند إجراء تقويمها بحالات عدم تأكد ذات أهمية نسبية متعلقة بأحداث أو ظروف قد تلقى شكوكاً كبيرة على قدرة المنشأة على الاستمرار كمنثأة مستمرة ، فإنه يجب على المنشأة أن تفصح عن حالات فله عدم التأكد تلك ـ و عندما لا تعد القوائم المالية على أساس الاستمر ارية فإنه يجب علبها أن تفصح عن هذه الحقيقة ، مع الأساس الذى عليه أعدت القوائم المالية وسبب أن المنشأة لا تعد منشأة مستمرة." . (Deloitte:2020 ) ، كما أشثار المعيار فى فقرته رقم جr إلى أنه " عند تقويم ما إذا كان فرض الاستمرارية بعد مناسباً يجب أن تأخذ الادارة فى الحسبان جميع المعلومات المتاحة عن المستقبل والذى يكون على الأقل ץ ا شهر من نهاية فترة التقرير ، فعندما يكون لدى المنشأة تاريخ من العمليات المربحة وسهولة للوصول إلى الموارد المالية فقد ثتوصل المنشأة إلى استتاج أن المحاسبة وفقاً لأساس الاستمرارية تعد مناسبة دون تحليل تفصيلى ، وفى حالات أخرى قد تحتاج الادارة أن تأخذ فى الحسبان مجموعة واسعة من العوامل المتعلقة بالربحية الحالية و المتوقعة ، وبر امج تسديد الدين و المصادر الممكنة لاستبدال التمويل قبل أن تصل إلى قناعة بأن أساس الاستمرارية بعد مناسباً. ( الهيئة السعودية

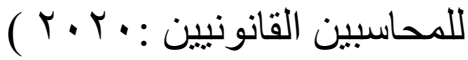




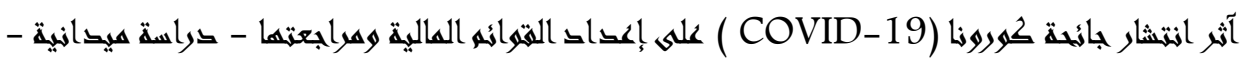
د/ وليد سهير عبد العظيه الجبلمى

و على ما سبق يرى الباحث أنه وفقاً لما ورد بالفقرتين أعلاه ، وفى ظل تفثى جائحة

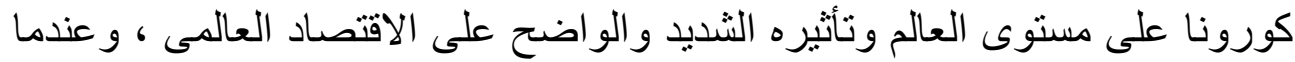

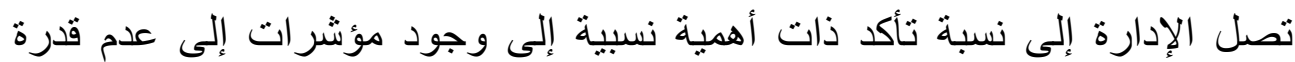

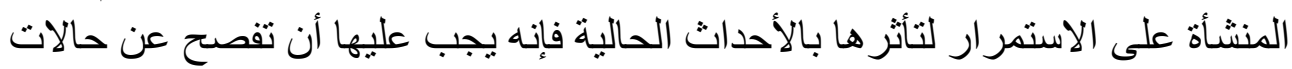

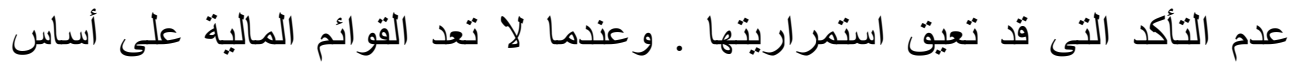

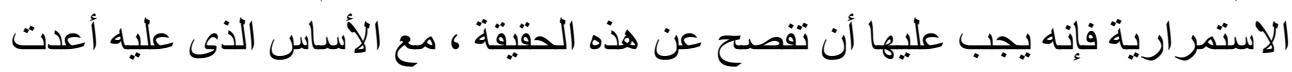

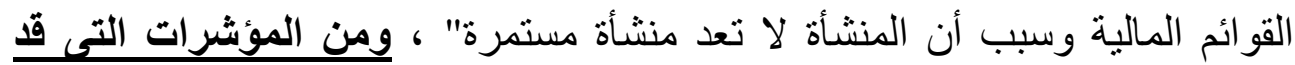

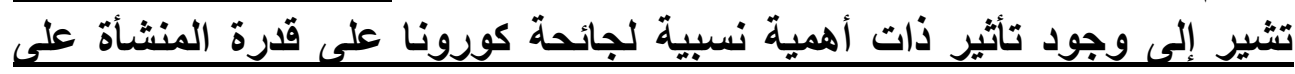

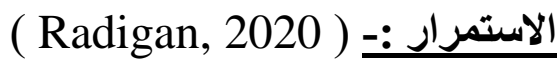
ل إفلاس (أو الإفلاس المحتمل) لعدد من كبار العملاء المدينون للشركة لمبالغ كبيرة

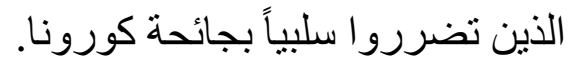

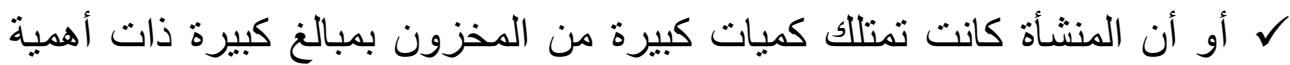

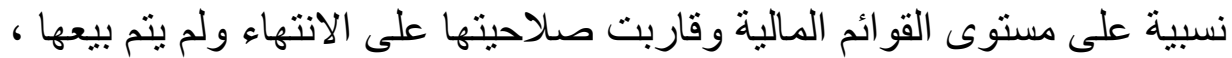
وتجد المنشأة صعوبات بالغة فى بيعها نتيجة إغلاق السوق المحلى و الدولى نتيجة

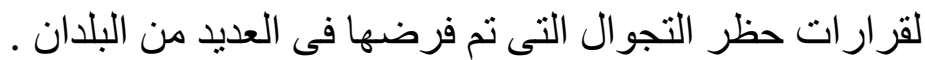

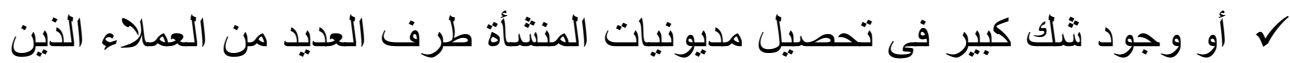

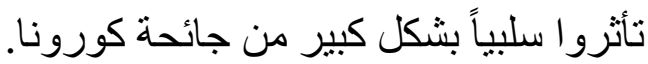

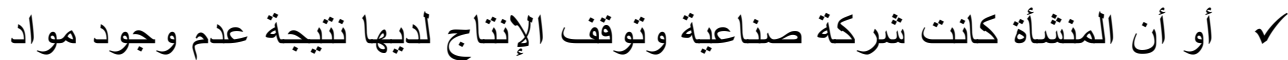

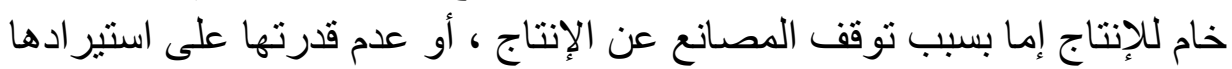

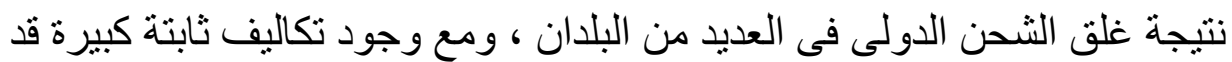

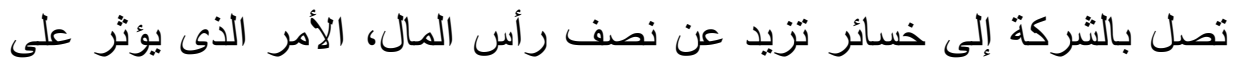

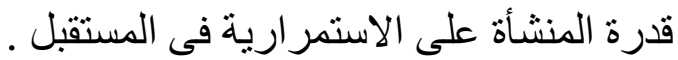
أو أن المنشأة قد أبرمت في الأه الماضى لعقود مع عملائها مفادها أن تقوم بتوريد

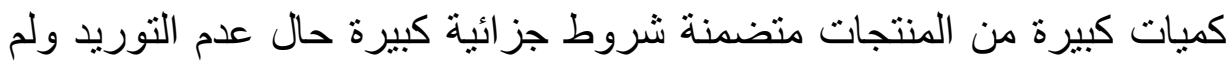
تقدر المنشأة على الوفاء بتلك التعاقدات نظر اً لتوقف الإنتاج. 


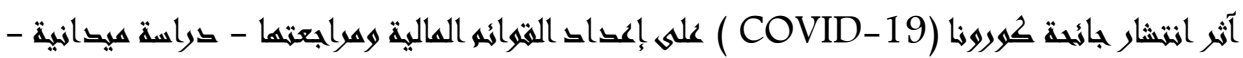
د/ وليخ سمير عمب العظيه الجبلمى

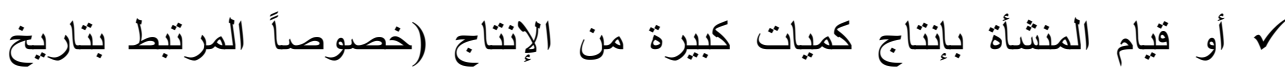

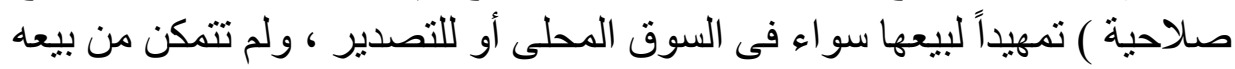

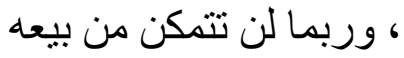
ل أو أن المنشأة عليها أقساط قروض لتهن مستحقة السداد للبنوك و لا تتو افر لديها السيولة

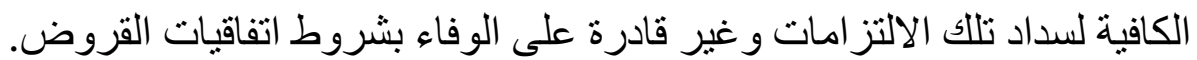

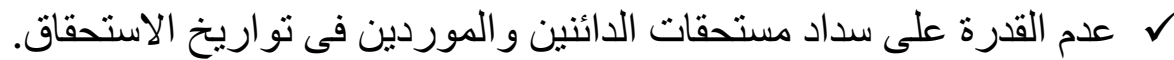

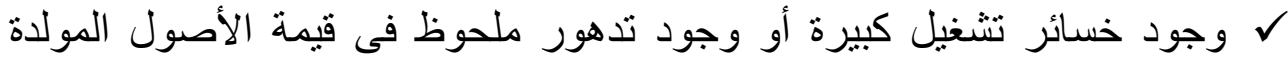

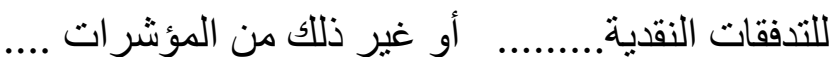

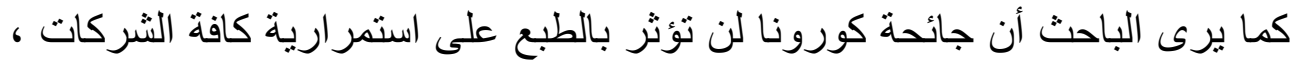

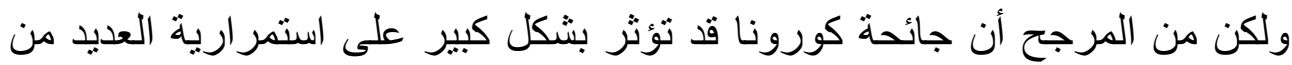

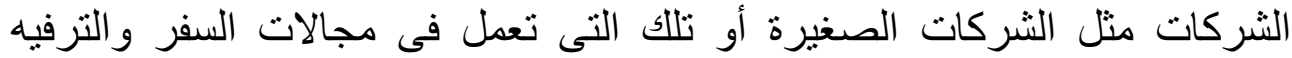

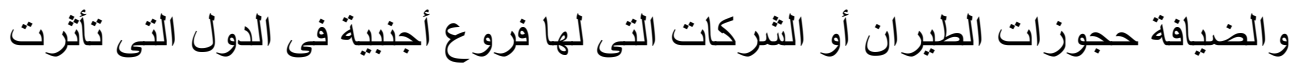

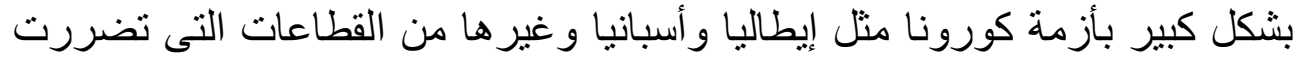

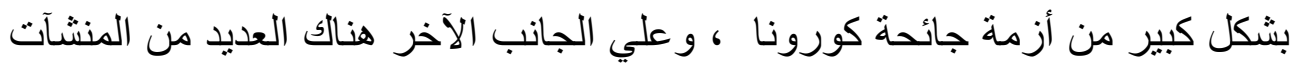

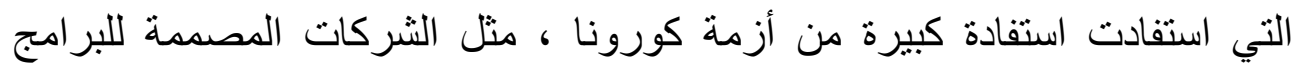

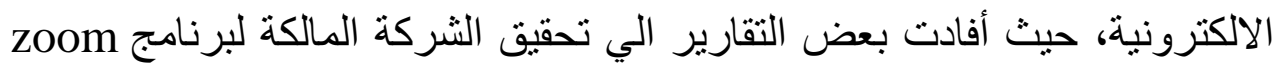

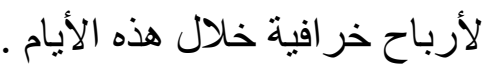

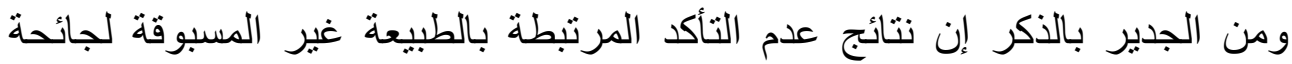

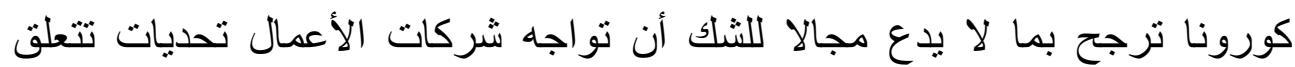

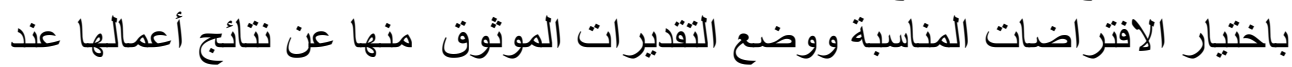

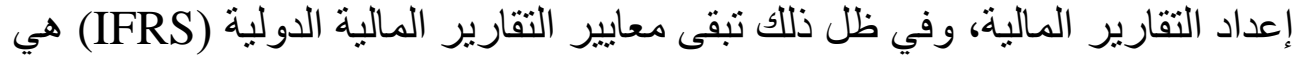

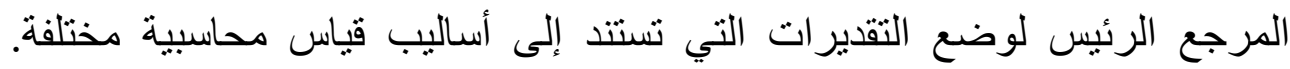

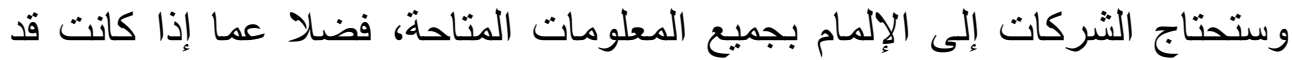

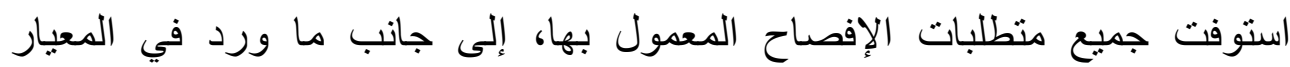

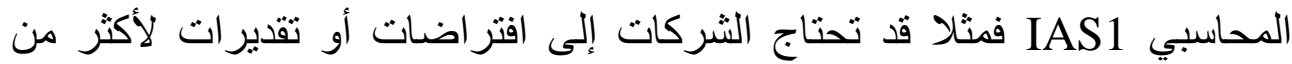




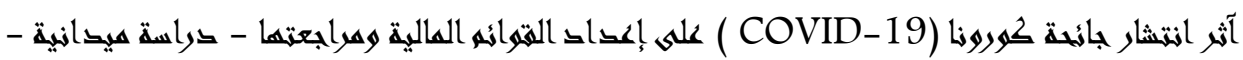
د/ وليب سمير عبد العظيه الجبملى

غرض واحد، فالإير ادات المتوقعة على سبيل المثال قد تكون ذات صلة باختبار ات

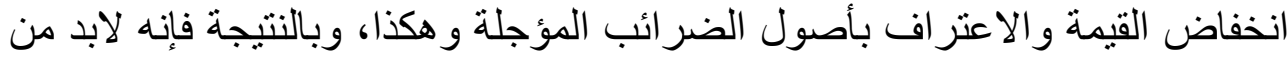

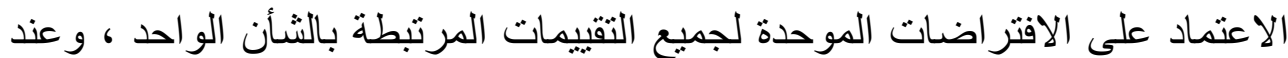
إعداد التقارير المالية في الأوقات غير المؤكدة، يكون من المهم إطلاع مستخدميها

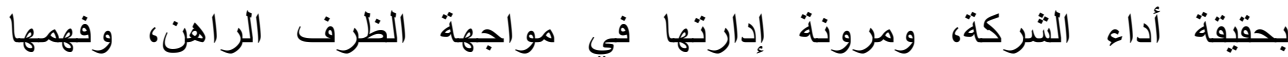

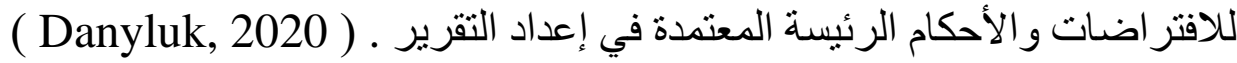
ويرى (Dave \& Mahanta, 2020) بضرورة التفكير جديا بالأحداث التي وقعت

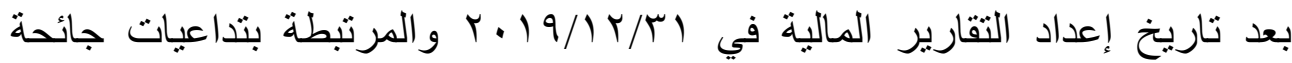

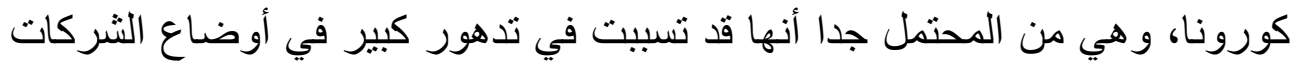
الاقتصادية إلى جانب الغموض وحالات عدم التأكد المصاحبة لها، و عليه يكون لز اما

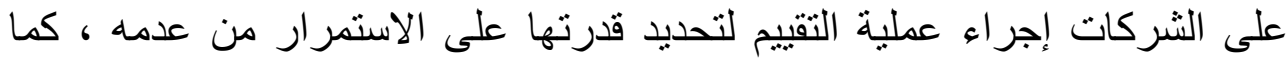

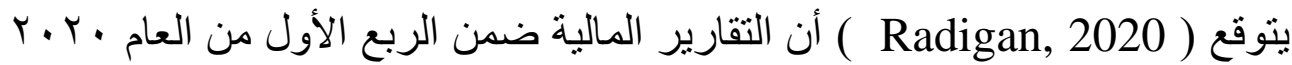

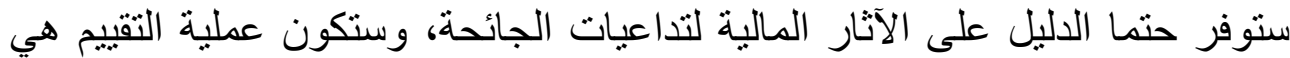

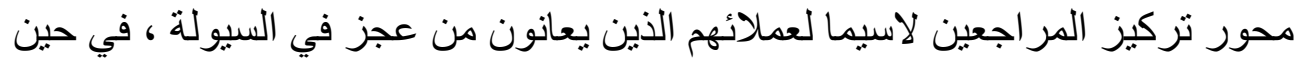

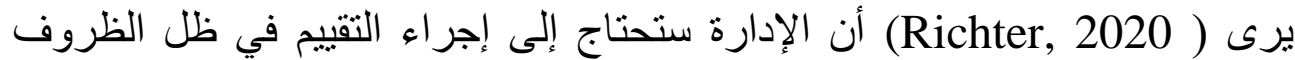

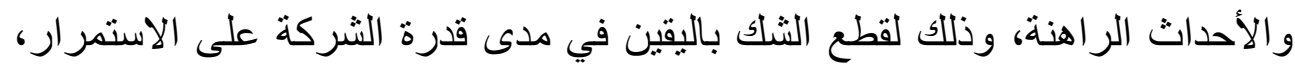

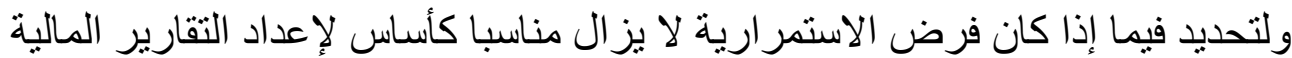

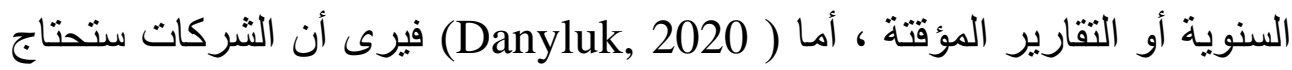

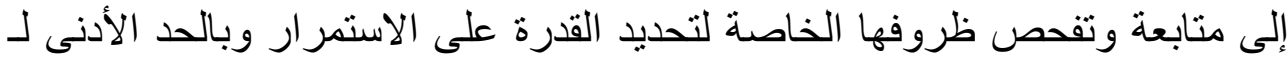

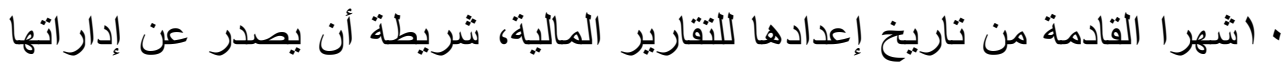

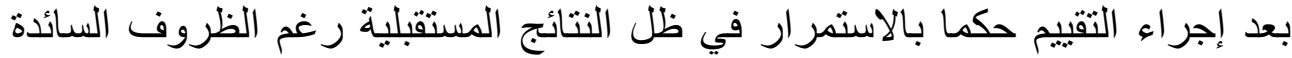
وحالة عدم التأكد، ويمكن القول أنه من جملة ما يتوجب متابعته فئه وأخذه بنظر الاعتبار لأغر اض التقييم ما يأتي: > تناقص الطلب المحتمل على المنتجات. 


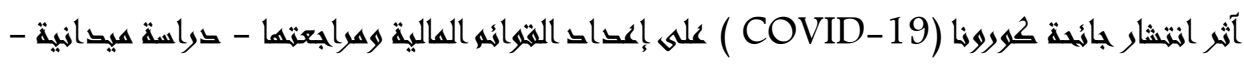
د/ وليخ سمير عمب العظيه الجبلمى

الالتز امات التعاقدية المستحقة أو المتوقعة خلال سنة واحدة.

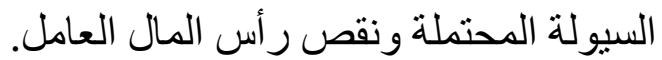

الوصول إلى مصادر رأس المال الحالية كخط الائتمان المتاح و المعونة المالة الحكو المكية.

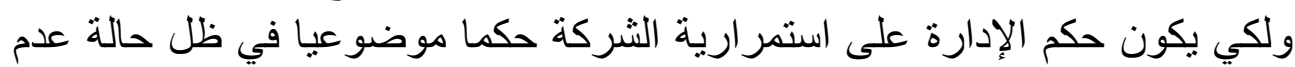

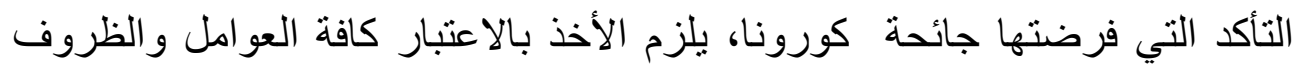

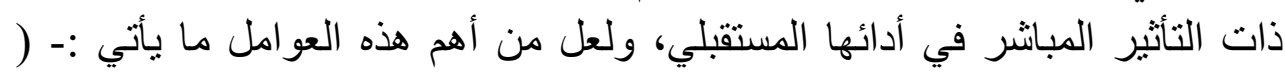

( Donato :2020 ا ا. الانخفاض الكبير في الإيرادات. r. التآكل الكبير في الأرباح بسبب ارتفاع التكاليف أو تكبد نفقات غير متوقعة.

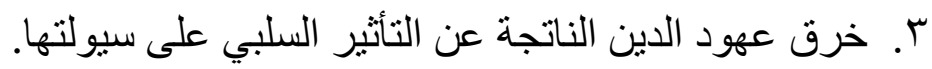
ع. قـضايا التدفق النقدي.

وبناء على ماسبق فإن نتائج تأثثر جائحة كورونا على الوظيفة المحاسبية فيما يخص

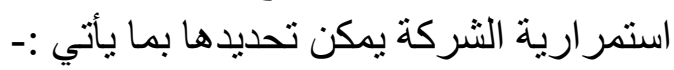

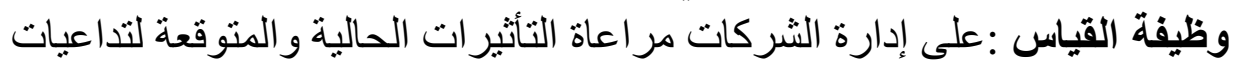

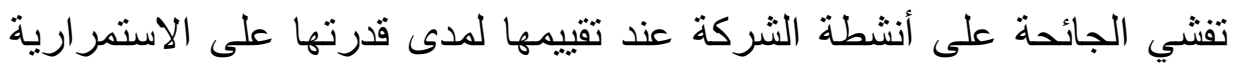

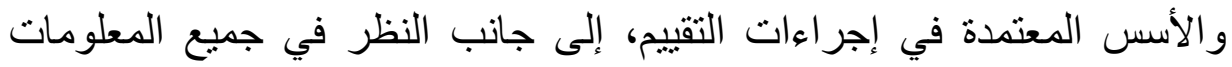

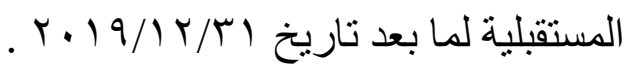

وظيفة الإفصاح :إن عدم القدرة على التنبؤ بالآثار المحتملة لتداعيات تفشي آندي

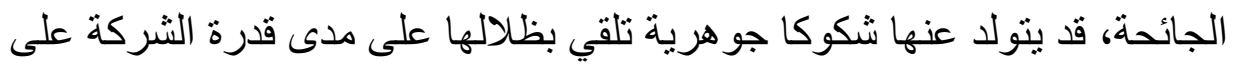

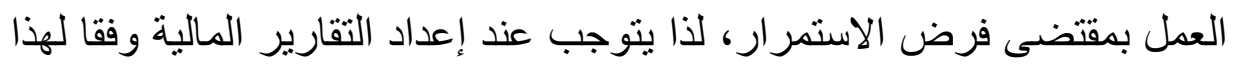

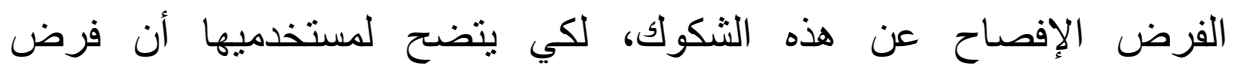

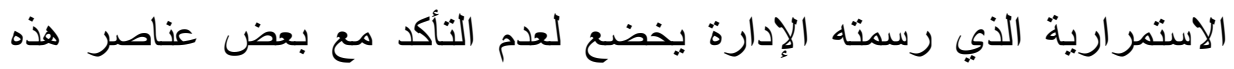

التقارير. 


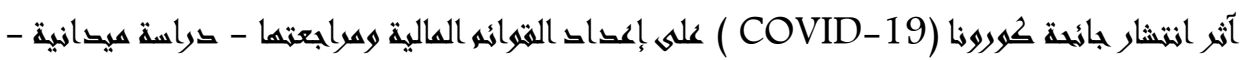
د/ وليق سمير عبد العظيه الجبلى

\section{IAS 36 بر/r/r} تتخفض قيمة الأصول عندما لا تكون الثركة قادرة على استرداد قيمتها الدفترية، سواء باستخدامها أو بيعها. وتقوم الثركة بتقدير القيمة القابلة للاسترداد الخاصة بالموجود لأجل اختبار انخفاض قيمته. ومن الجدير بالذكر أن اختبار انخفاض القيمة لأي موجود يقاس بالمبلغ القابل للاسترداد مقارنة بقيمة استخدامه أيهما أكبر. ومتى ما زادت القيمة الدفترية للأصل (أو وحدة توليد النقد التي ينتمي لها الأصل Cash-Generating Unit: - CGU هي أصغر مجموعة من الأصول القابلة للتحديد التي تولد تدفقات نقدية بشكل مستقل نسبيا عن التدفقات النقدية الناتجة عن الأصول الأخرى. ويتم استخدام وحدة توليد النقد في حالة عدم القدرة على تحديد المبلغ القابل للاسترداد للموجود بصورة منفردة ) عن تللك القيمة الأكبر الناتجة عن المفاضلة بين المبلغ القابل للاسترداد وقيمة الاستخدام فيمكن الجزم حينها أن هنالك انخفاضا فعليا في قيمة الموجود. وللعلم إن المبلغ القابل للاسترداد هو عبارة عن القيمة العادلة للموجود مطروحا منها تكاليف استبعاده (تكاليف بيعه)، أما القيمة المستخدمة فهي القيمة المضافة أو القيمة الحالية للتدفقات النقدية المستقبلية المتوقع أن يتم اشتقاقها من

الموجود أو وحدة توليد النقد ( EY, 2020 ) . عليه فإن من آثار تفثي جائحة كورونا انعكاسها في إجراءات التغير بالتقديرات

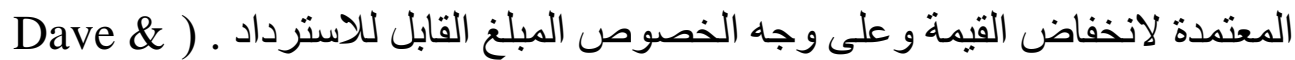

. ( Mahanta, 2020

ومما يجب التأكيد عليه أن الثركات ستحتاج إلى ثقييم ما إذا كان لآثاره دافعا لانخفاض فيم أصولها ـ فقد يتأثز أداؤها المالي بما في ذللك تقديرات تدفقاتها النقدية وأرباحها المستقبلية بالآثار المباشرة وغير المباثرة بالأحداث الناتجة عنه. ويسعى معيار انخفاض قيمة الأصولIAS36 إلى التأكد من أن أصول الثركة لا يتم إدراجها بما لا يزيد عن قيمتها القابلة للاسترداد، وفي نفس الوقت يكون من الواجب على مالى الثركات إجراء اختبارات القيمة عندما بكون لديها مؤشرا على انخفاض قيمة الموجود في تاريخ التقرير. كما أشار المعيار أيضا إلى ضرورة إجراء الاختبار 


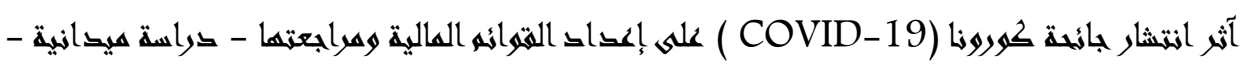
د/ وليد سهير عبد العظيه الجبلمى

لوحدة توليد النقد CGU عندما لا ينتج الأصل تدفقات نقدية مستقلة مقارنة مع تلاك

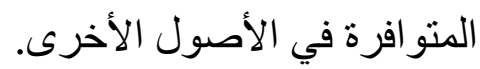

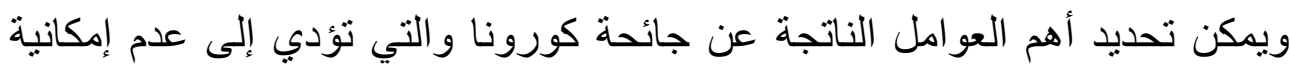

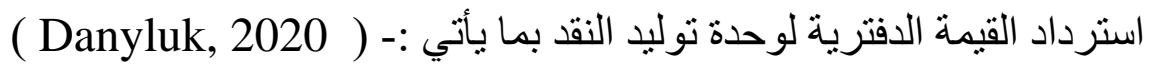
( ) انخفاض الطلب على منتجات أو خدمات الثركة. (r

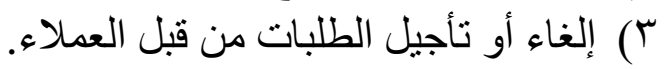

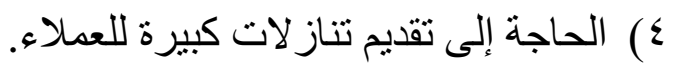

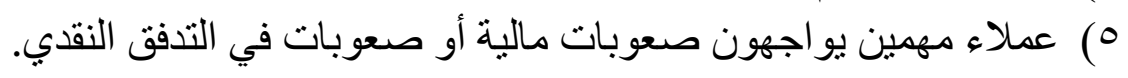

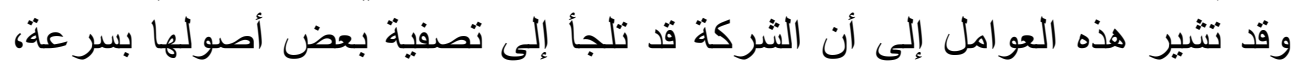

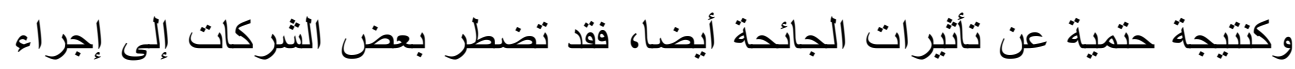

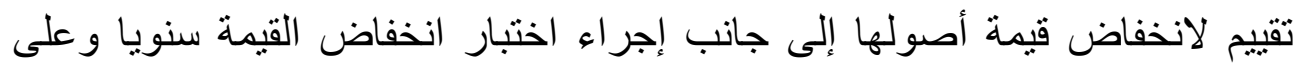

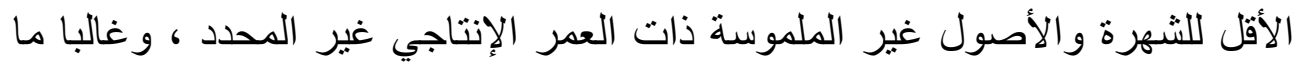

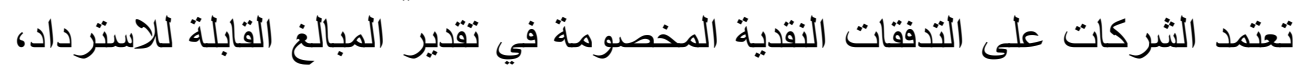

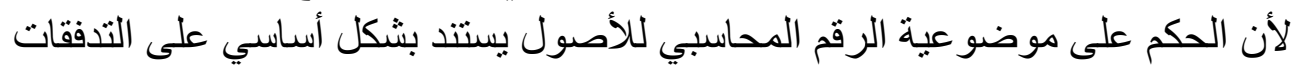

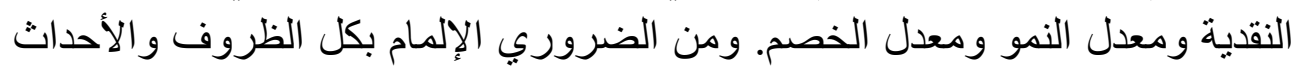

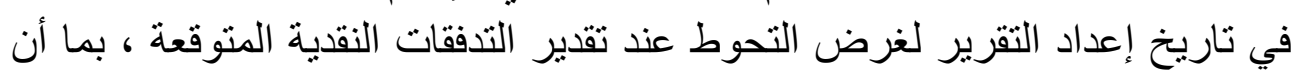

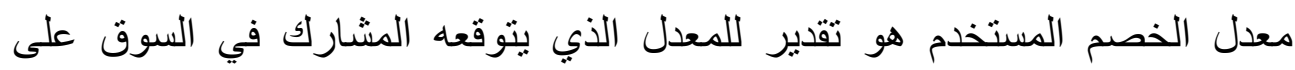

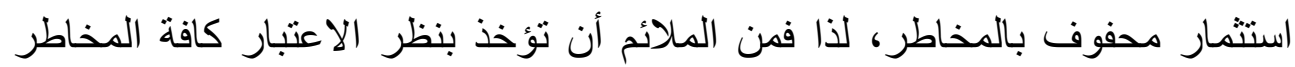

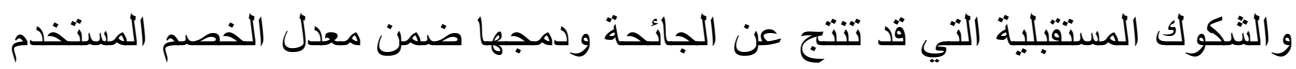

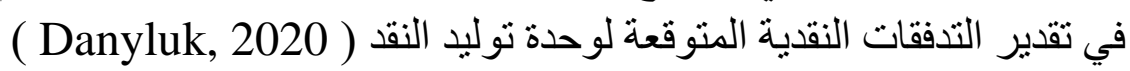

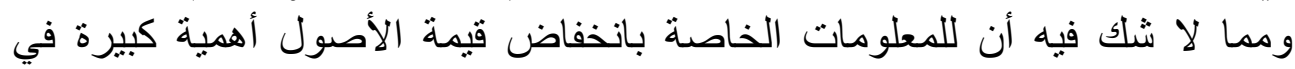

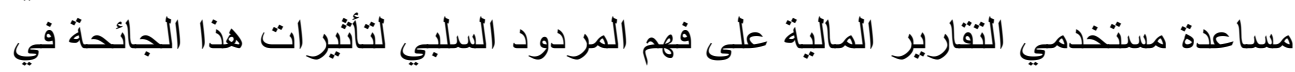

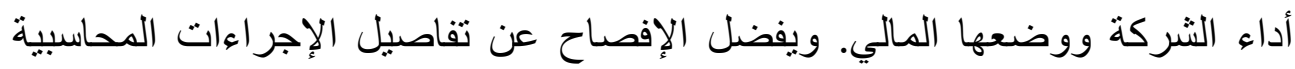

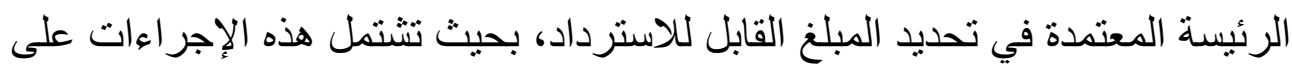




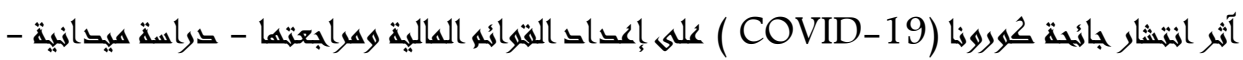
د/ وليق سمير عبد العظيه الجبلى

كافة آثاره مع الأخذ بالاعتبار احتمالية عودة الحياة إلى طبيعتها وانتعاش الأنشطة عند انتهائه، و غالبا ما تمثل هذه الإجر اءات أيضا الأساس لاختبار ات انخفاض القيمة في ظل عدم التأكد، لذا قد بتطلب ذلك معلومات إضافية بالإمكان توفير ها من خلال المعيار المحاسبيIAS1 مثل تحليل الحساسية بهدف سد الحاجة للمعلومات المطلوبة في المعيار IAS36 ، و عليه فإنه عند تقدير القيمة القابلة للاسترداد بيتوجب أن تعكس التدفقات النقدية المتوقعة أفضل تقدير ات الإدارة عن الأوضاع الاقتصادية التي ستحيط بالموجود طيلة العدر الإنتاجي المتبقي له. (Deloitte:2020 ) ، وبناء على ما سبق فإن نتائج تأثير جائحة كورونا على الوظيفة المحاسبية فيما يخص انخفاض

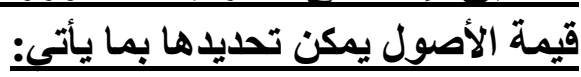

وظيفة القياس :إن المدى الزمني للأصول غير المتداولة هو في العادة طويل الأجل، ومن ثم فإنه في ظل هذه الظروف ستشكل التوقعات حول التدفقات النقدية المستقبلية تحديا فعليا أمام الإدارة، لذا يتوجب عليها وأن تأخذ بالاعتبار تأثنير ات الجائحة على المدى الطويل إلى جانب تأثير اته في المدى القصبر. وظلفة الإفصاح :ينبخي على الثركات الإفصاح عن الإجراءات التي قامت بها و أدت إلى تغيير عملية تقدير القيمة القابلة للاسترداد نتيجة لآثار تفثي الجائحة. r/ نشرت شركة Deloitte وهي إحدى المكاتب الأربعة الكبار ( Big Four) ذات التخصص في تدقيق الحسابات، تحذيرات للمحاسبين بأن فيمة الأدو ات المالية ستصبح أكثر تقلبا، مشيرة إلى أن التقارير المالية و الافصاحات ذات الصلة ستكون بحاجة إلى بلى نقل جميع الآثار المادية لجائحة كورونا. ويؤكد ( Richter, 2020 ) على أهمية تعديل الأصول والالتز امات المقيمة بالقيمة العادلة في ظل تداعيات الجائحة، إذ بعكس قياس القيمة العادلة شروط تقدير ها كما هي في تاريخ القياس، وقد تكون عملية القياس صعبة نو عا ما عند استنادها على ظروف ضبابية قد تخل بشروط التقدير مثلا ولم تدركها الثركة في وقت تقدير القيمة العادلة، وتزداد هذه الصعوبة مع التغير السربع في الظروف الحالية. 


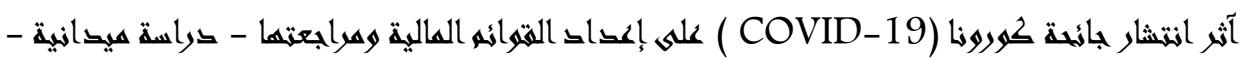
د/ وليخ سمير عمب العظيه الجبلمى

وبناء على ما سبق فإن نتائج تأثثير جائحة كورونا على الوظيفة المحاسبية فيما يخص

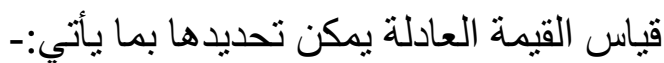

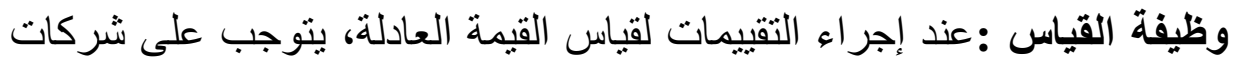

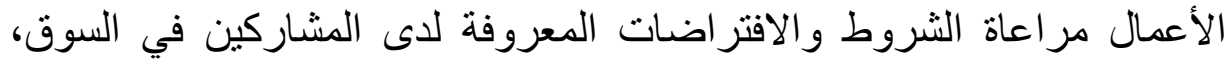

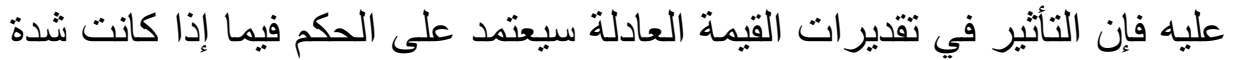

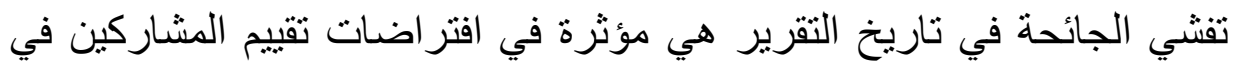
ذلك التاريخ.

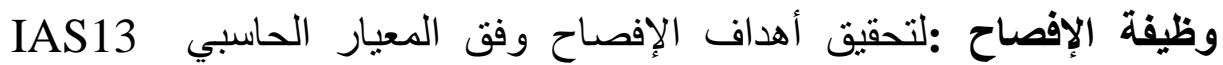

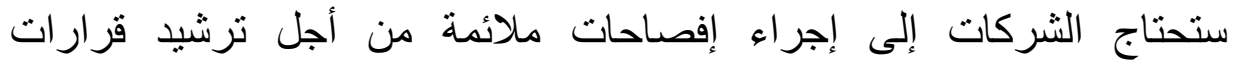
المستخدمين الأساسيين للتقارير المالية، وقد تكون هناء الك حاجة إلى إلى إفصاحات

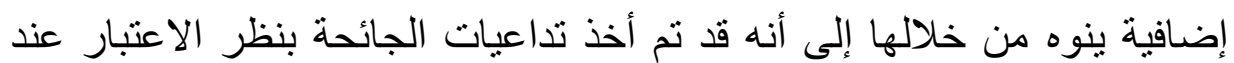
قياس القيمة العادلة.

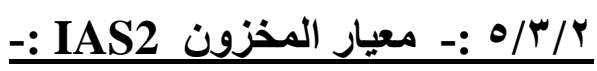

يتم قياس المخزون وفق المعيار المحاسبي الدولي IAS2 بسعر المجني التكلفة أو صافي القيمة القابلة للتحقق NRV أيهما أقل. وفي ظل بيئة اقتصادية غير مستقرة، قد يكون

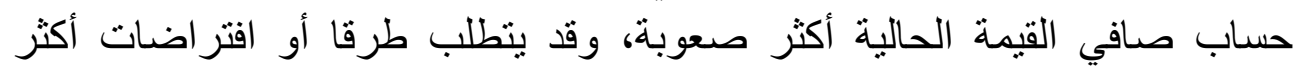

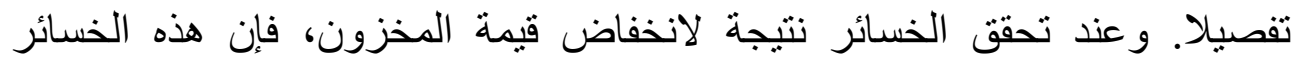

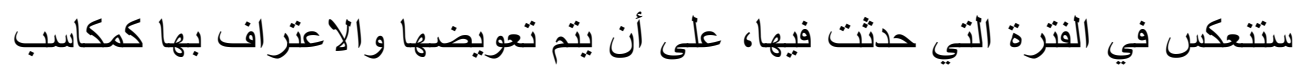
في الفترات اللاحقة عند عودة ارتفاع قيمته مرة أخرى.

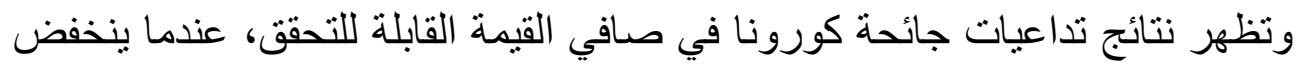

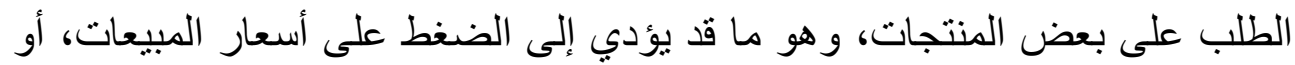

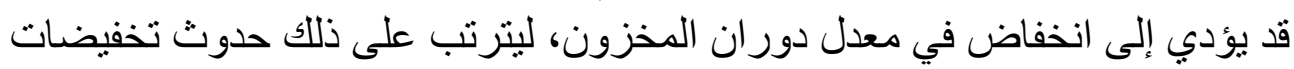
إضافية في صافي هذه القيمة (Richter, 2020 ) قد تؤثر تداعيات الجائحة أيضا على قابلية استرداد أرصدة المخزون، إذ قد تضطر بعض الثركات التي لديها قوائم

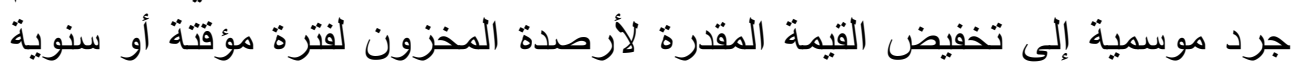




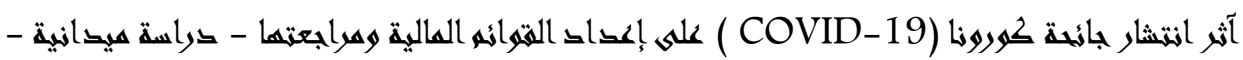
د/ وليد سهير عبد العظيه الجبلمى

نتيجة لضعف أو انخفاض مستويات المبيعات المتوقعة، كما قد تضطر الثركات الصناعية إلى إعادة تقييم ممارساتها الخاصة بمعدلات تحمبل التكاليف العامة الثابتة نتيجة للانخفاض المتوقع في حجم الإنتاج بشكل غير طبيعي خلال العام نتيجة لإغلاق المصانع أو انخفاض الطلب على منتجاتها ( Danyluk, 2020 ) . بناء على ما سبق فإن نتائج تأثير جائحة كورونا على الوظيفة المحاسبية فيما يخص تقييم المخزون بمكن تحديدها بما بأتي :وظلفة القياس :يتوقع أن يكون هناك صعوبات في تقدير صافي القيمة القابلة للتحقق، نتيجة لتداعيات الجائحة السلبية غير المحددة من حيث نطاق التأثير ومدته، و التي ستتعكس في الغالب بالتخفيضات الإضافية التي ستجرى على تلك

القبه.

وظيفة الإفصاح :على الثركة الإفصاح بصورة كاملة عن الآثار التي خلفها الجائحة أو سيخلفها مستقبلا في القيمة المقدرة الصافية للمخزون. r/ץ/ץ يعرف معيار المحاسبة الدولي رقم Vr المخصصات و الالتز امات المحتملة و الأصول المحتملة ، المخصص على أنه التزام غير مؤكد من حيث توقيته أو مبلغه. والالتز ام بطبيعته هو واجب قائم على المنشأة ناشئ عن أحداث سابقة، ويتوقع أن ينتج عن مؤن تسويته تدفق خارج من المنشأة لموارد تتطوي على منافع اقتصادية. و الواجب القائم على المنشأة قد يكون واجباً نظامباً ناشئاً على سبيل المثال عن عقد أو نظام معين، أو لو و اجبا" ضمنيا" ناشئا عن تصرفات المنشأة عندما توحي لأطر اف أخرى، من واقع ذأق ممارسة سابقة ذات نمط ثابت، أو من واقع سياسات معلنة أو تصريح حالي محدد بشكل كاف، بأنها سوف تقبل مسؤوليات معينة؛ ونتيجة لذللك، تكون المنشأة قد أوجدت توقعا" وجيها لدى تللك الأطر اف الأخرى بأنها سوف تفي بتلك المسؤوليات. وفي ظل ظروف فيروس كوفيد- 9 (قد لا يكون من الو اضح وجود و اجب قائم في تاريخ القو ائم المالية (على سبيل المثنال الغرامات المترتبة على تأخير تنفيذ أعمال معينة بسبب ظروف الفيروس.) ويوضح معيار المحاسبة الدولي رقم TV أنه في هذه الحالات، يعد 


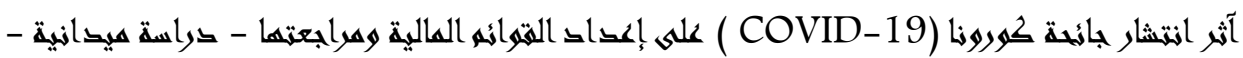
د/ وليق سمير عبد العظيه الجبلى

أن هناك حدثاً سابقا ينشأ عنه واجب قائم إذا كان وجود واجب قائم في نهاية فترة التقرير أمراً يترجح حدوثه أكثر من عدمه، مع الأخذ في الحسبان فئان جميع الأدلة

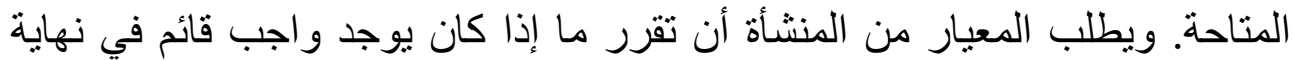

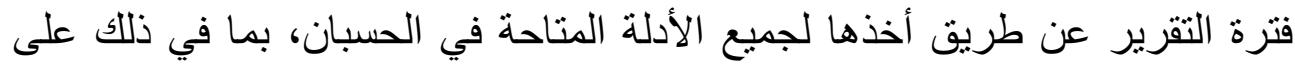

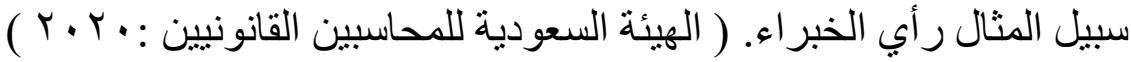

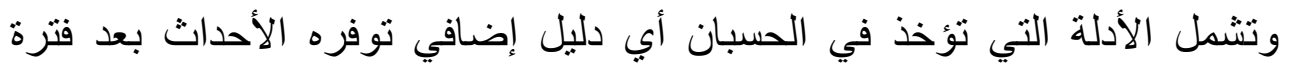

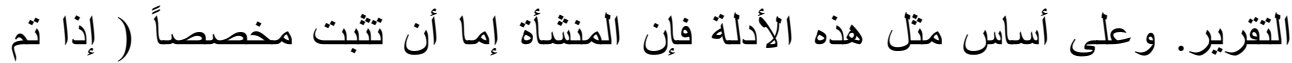
استيفاء ضو ابط الإثبات) عندما يكون وجود واجب إنب قائم في نهاية فترة التقرير أمراً

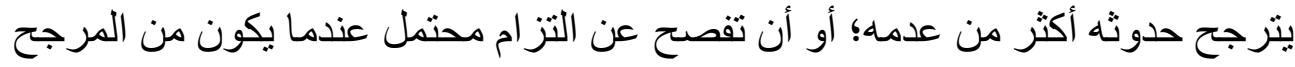

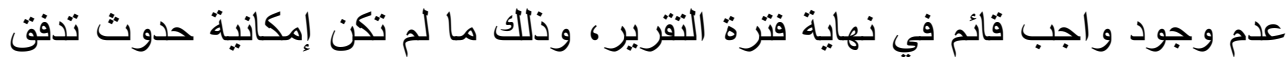

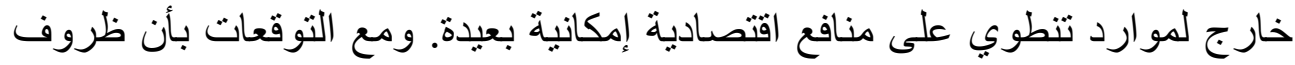

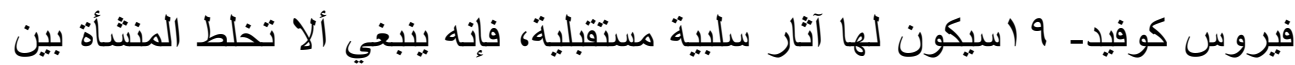
المخصصات (وفقا لتعريف المعيار) وبين التكاليف المستقبلية المتعلقة بالتشغيل

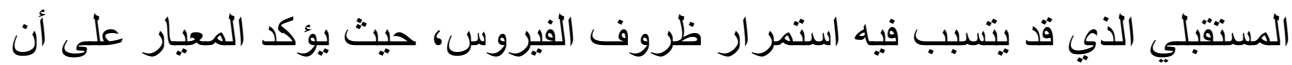

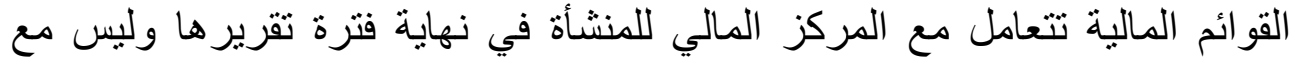

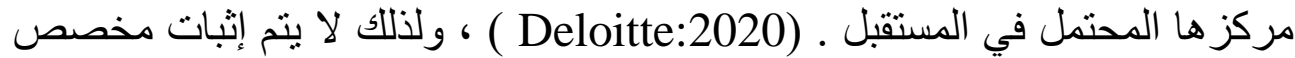
للتكاليف التي سيكون من اللازم تكبدها للتشغيل في المستقبل. والالتزامات التهات الوحيدة

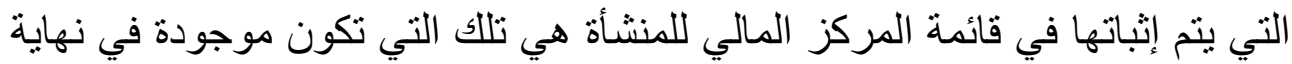
فترة التقرير. ومع ذللك فإنه يجب أن تنعكس الأحداث المستقبلية، التي يمكن أن تؤثر التي

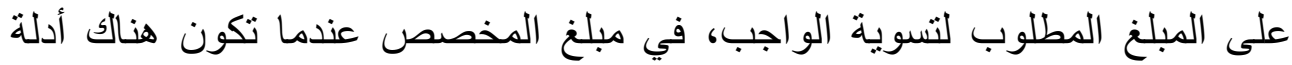
موضوعية كافية على وقوعها. ويؤكد المعيار في هذا الصدد أن الخسائر التشغيلية

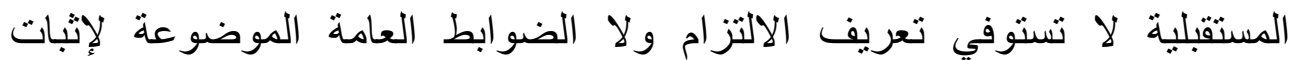

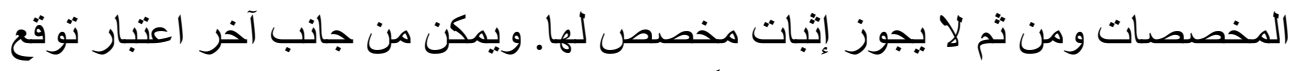
حدوث خسائر تشغيلية مستقبلية مؤشراً على احتمال هبوط قيمة أصول تشغيلية معينة.

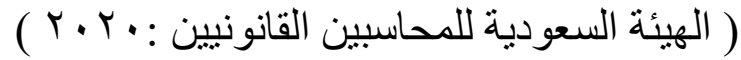




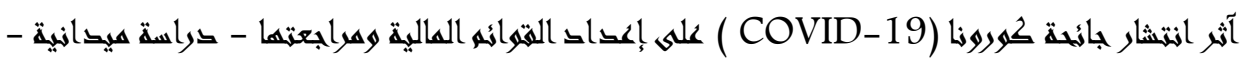
د/ وليد سهير عبد العظيه الجبلمى

وتختبر المنشأة هذه الأصول لتحديد الهبوط في قيمنها بموجب المعيار الدولي

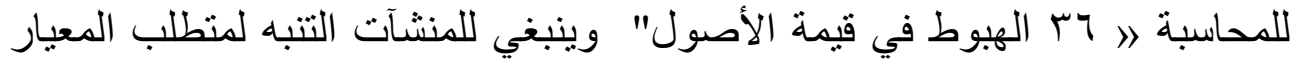

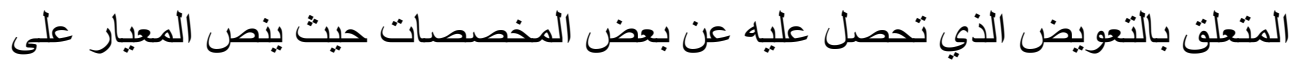

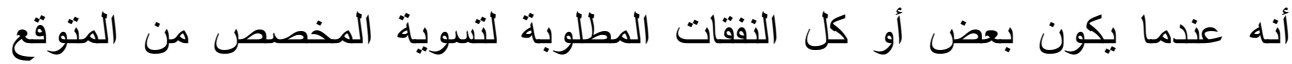

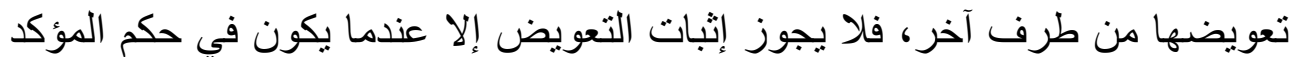

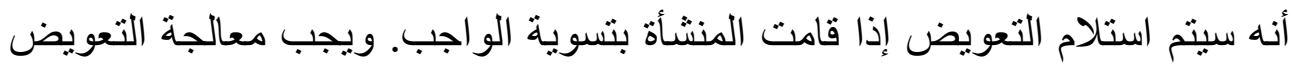

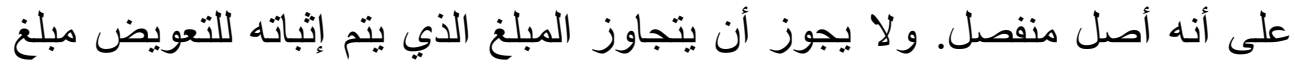

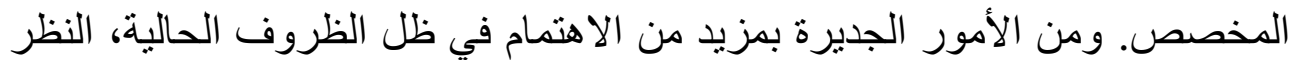

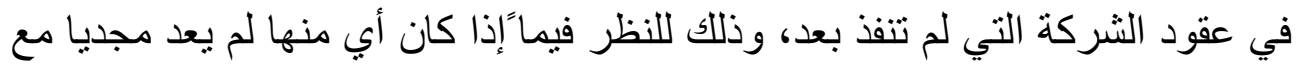

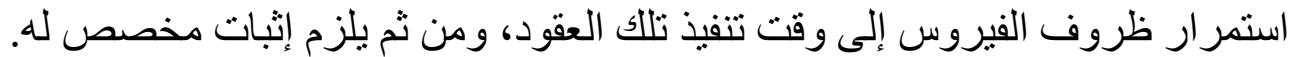

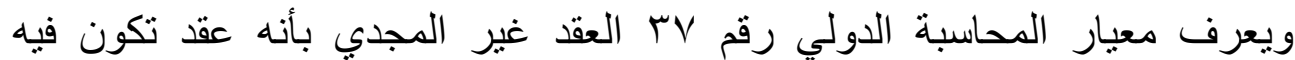

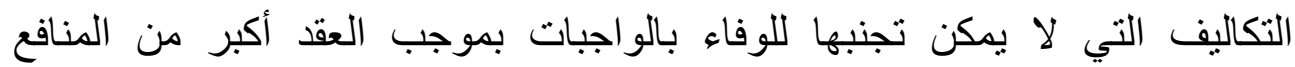

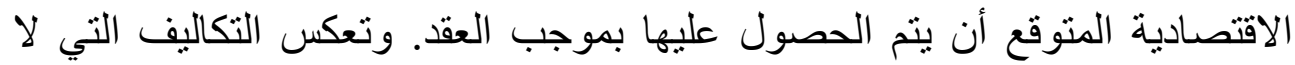

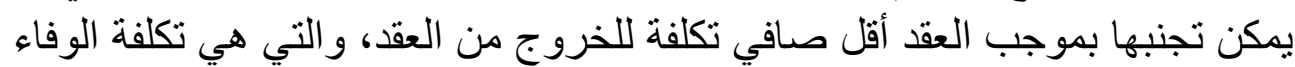

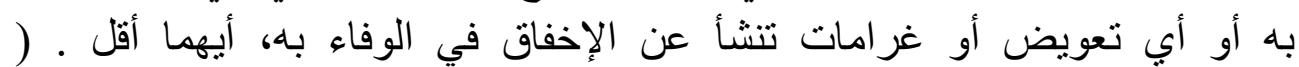

( PWC:2019

\section{وعلى ما سبق يرى الباحث :-}

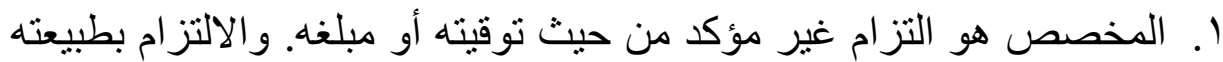

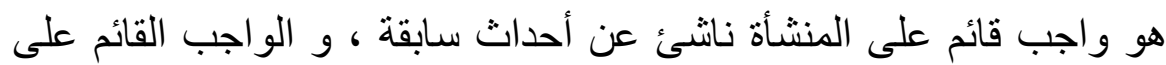

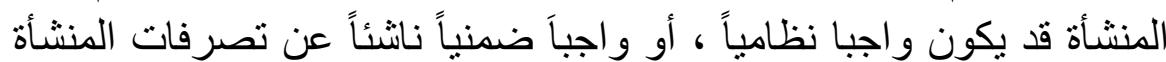

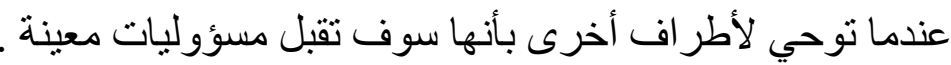

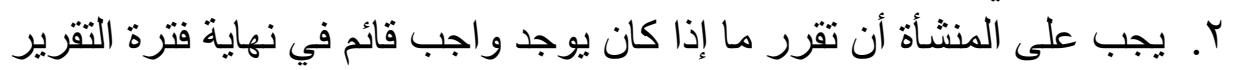

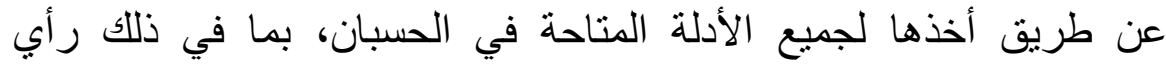

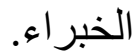




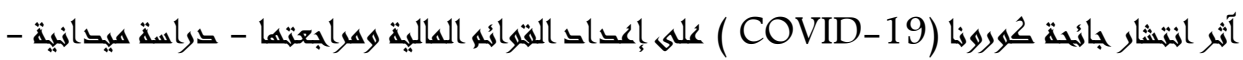
د/ وليق سمير عبد العظيه الجبلى

r. تشمل الأدلة التي تؤخذ في الحسبان عند تحديد وجود مخصص أي دليل

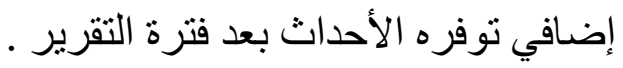

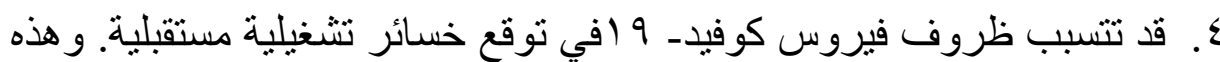

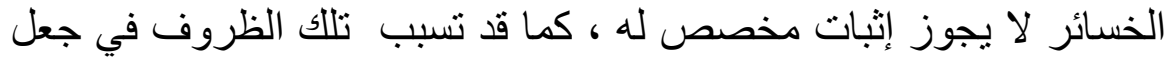

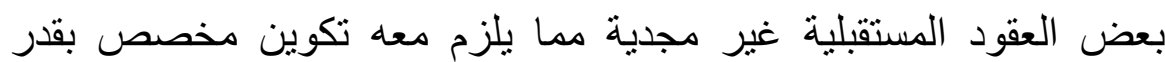

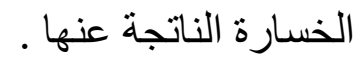

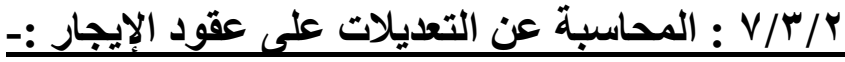

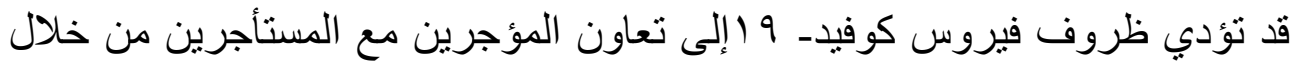

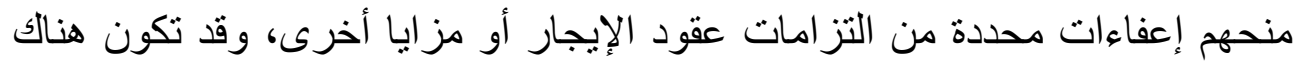

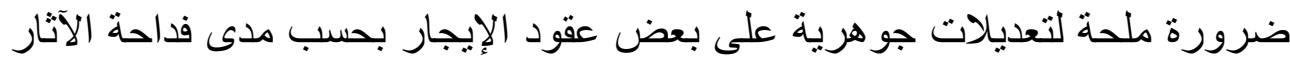

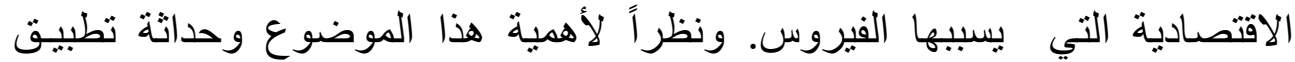
المعيار الدولي للتقرير المالي رقم 》 7 اعقود الإيجاره فقد أصدر مجلس معايير

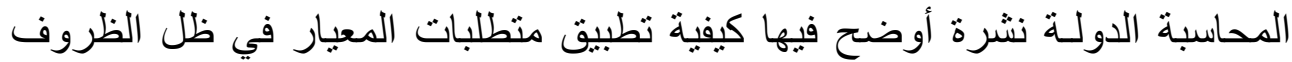

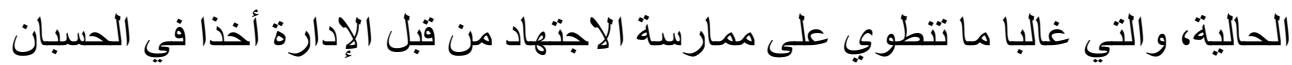

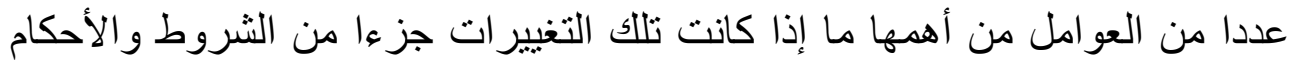

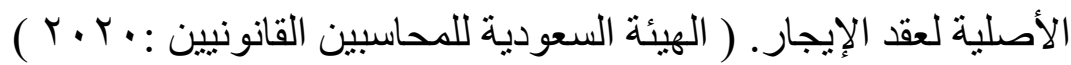
ويمكن أن تنشأ التغييرات بشكل مباشر عن تعديلات في عقد الإيجار نفسه أو بشكل

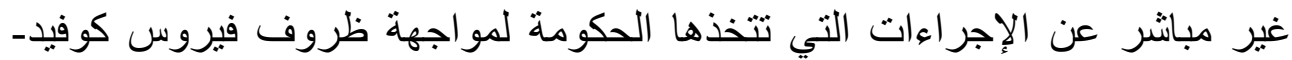
9 او عند المحاسبة عن التغييرات في دفعات الإيجار، تنظر المنشأة في عقد الإيجار

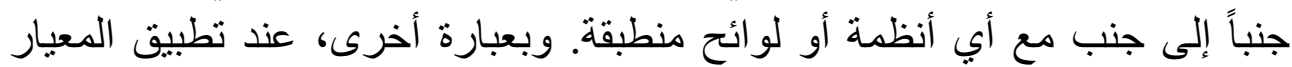

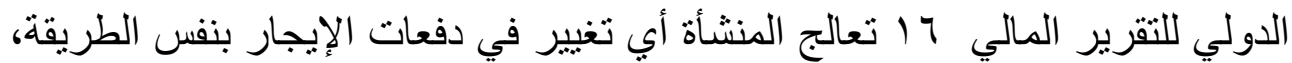

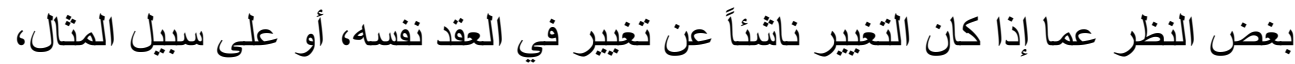

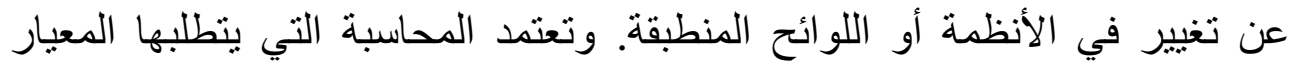

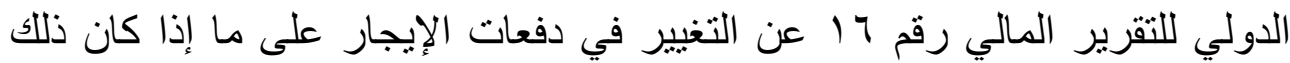




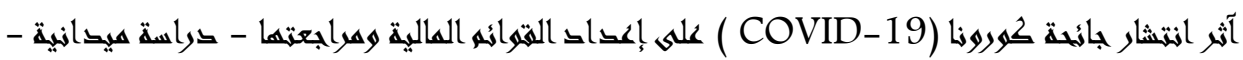
د/ وليد سهير عبد العظيه الجبلمى

التغيير يستوفي تعريف تعديل عقد الإيجار. ووفقاً لنشرة المجلس الدولي، فإن من أهم

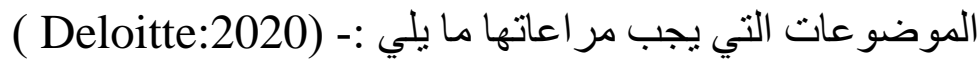

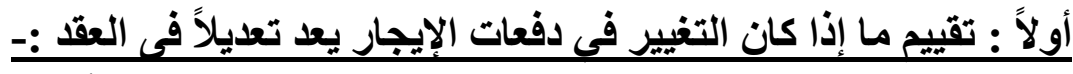

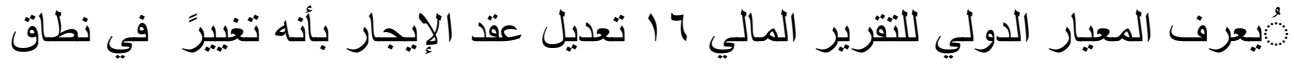

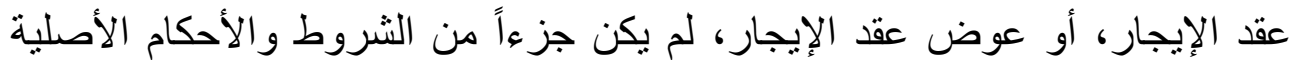

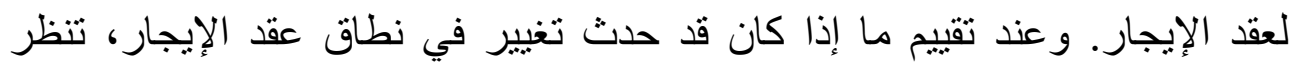

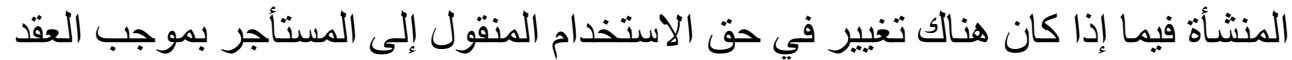

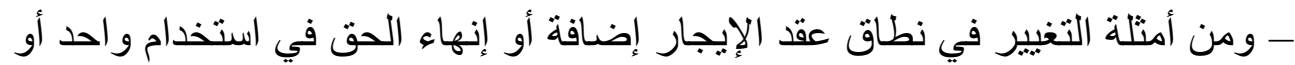

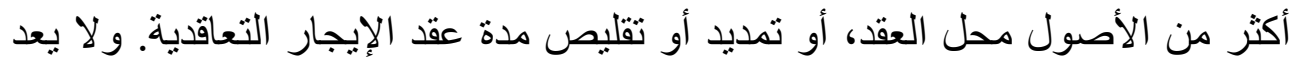

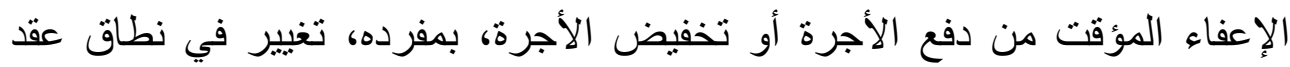

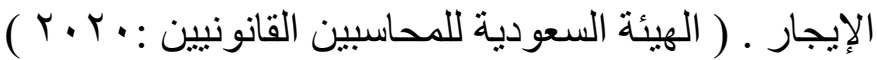

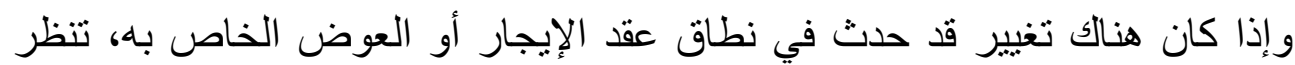

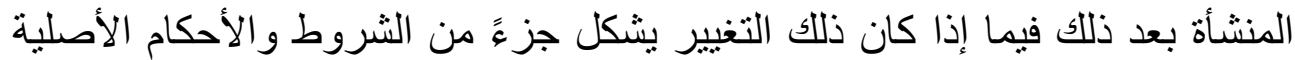

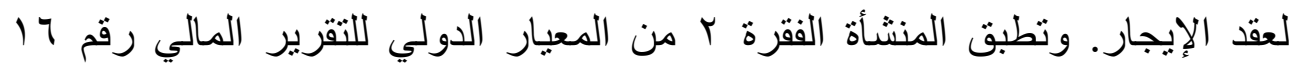
وتنظر في كل من الثروط والأحكام الخاصة بالعقد وفي جميع الحقائق والظرئ التروف

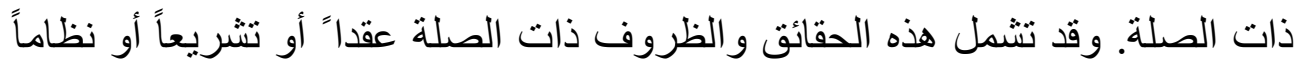
أو لائحة أخرى منطبقة على عقود الإيجار .

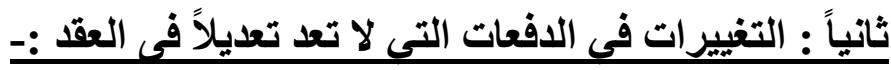

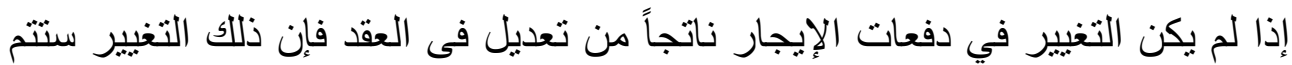

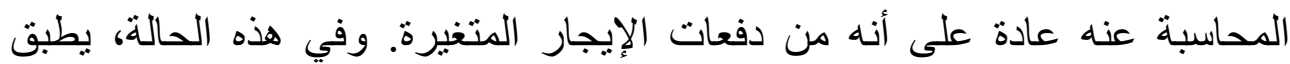

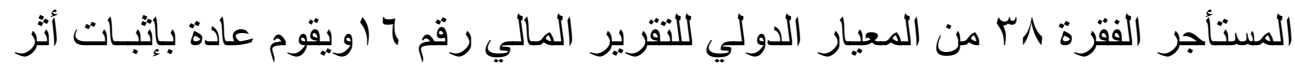

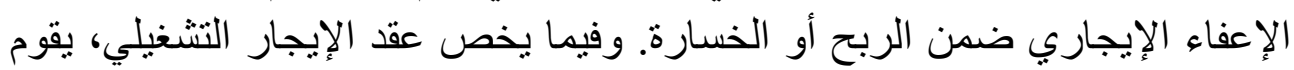
المؤجر بإثبات أثر الإعفاء الإيجاري عن طريق إلثاري إتبات دخل منخفض من عقود

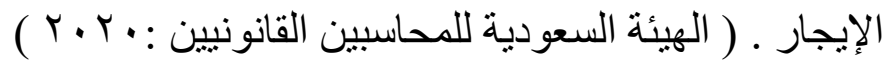




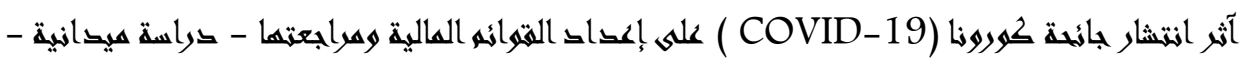
د/ وليق سمير عبط العظيه الجبلمى

\section{ثالثاً : التخلص الجزئى من التزام عقد الإيجار:}

إذا أدى التغيير في دفعات الإيجار إلى التخلص من جزء من الواجب المحدد في العقد على المستأجر (على سبيل المثال، إبراء المستأجر نظاما من الواجب الذي عليه بأداء دفعات محددة على وجه الخصوص،) بنظر المستأجر فيما إذا كانت المتطلبات الخاصة بإلغاء للفقرة ا.ب.r إثبات جزء من التزام عقد الإيجار قد تم استيفاؤها وفقا من المعيار الدولي للتقرير المالي رقم \ا 9 الأدوات المالبة " . (Deloitte:2020 )

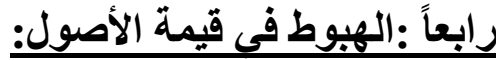

يطبق المعبار الدولي للمحاسبة رقم 》 حسالهبوط في قيمة الأصول《) عند تحديد ما إذا كان قد حدث هبوط في قيمة أصول حق الاستخدام (فيما يخص المستأجر) وبنود العقار ات و الآلات و المعدات الخاضعة لعقد الإيجار التشغيلي (فيما يخص المؤجر) ومن المرجح أن تدل الظروف، التي تنشأ عنها إعفاءات إيجاريه نتيجة لظروف لإنه فيروس كوفيد- ، 9 ا على حدوث هبوط في قيمة الأصول. فعلى سبيل المثال، قد بكون فوات الربح أثناء الفترة التي تشملها الإعفاءات الإيجارية مؤشرا على حدوث هبوط في قيمة أصل حق الاستخدام ذي الصلة. وبالمثل، قد تؤثز الآتار طويلة الأجل لظروف فيروس كوفيد- 9 اعلى الأداء الاقتصادي الدائم المتوقع لأصول في المتطلبات حق الاستخدام. وسيلزم على المؤجر أن بنظر أيضا المنطبقة الواردة في المعبار الدولي للتقرير المالي رقم 9 على سبيل المثال عند المحاسبة عن أي هبوط في قيمة المبالغ مستحقة التحصيل فيما يخص عقود الإيجار . (Davies, 2020)

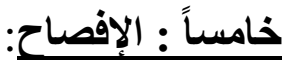

يجب على المستأجر و المؤجر تطبيق متطلبات الإفصاح الواردة في المعابير الدولية الأخرى للتقرير المالي، منثل المعيار الدولي للمحاسبة رقم 》 ا عرض القوائم المالية.ی) فعلى سبيل المثال، يتطلب المعيار الدولي للتقرير المالي رقم 7 المن من كن من المستأجرين و المؤجرين لمستخدمي القوائم الإفصاح عن المعلومات التي توفر أساساً المالية لتقييم أثر عقود الإيجار على مر اكز هم المالية و أدائهم المالية وتدفقاتهم النقدية .

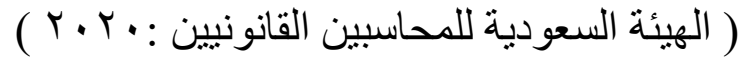




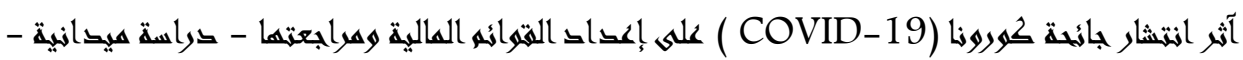
د/ وليخ سمير عمب العظيه الجبلمى

\section{على ما سبث يرى الباحث :-}

•خ ظروف فيروس كوفيد-9 ا قد تؤدي إلى تعديلات في عقود الإيجار ، كيفية تطبيق متطلبات المعبار في ظل الظروف الحالية، و التي غالبا ما تتطوي على ممارسة

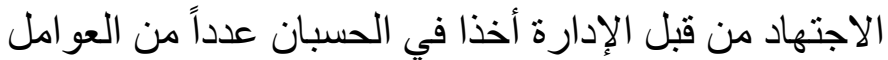
هو يمكن أن تكون الإجراءات الحكومية (مثل، فرض إغلاق المتاجر لفترةزمنية بسبب ظروف فيروس كوفيد-) 1 ذذات صلة بالتفسير القانوني للقوة القاهرة، المنصوص عليها في العقد الأصلي أو اللوائح المنطبقة . يلز م أن تكون المعلومات المفصح عنها كافبة لتمكين مستخدمي القو ائم المالبة من فهم آثار التغيير ات في دفعات الإيجار ، نتيجة لظروف فيروس كوفيد-9، 1 على المركز المالي للمنشأة و أدائها المالي . المئي

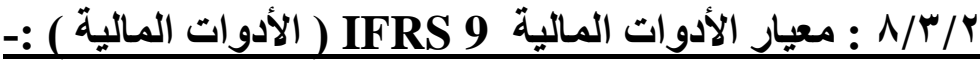

دخل المعيار الدوليIFRS9 الأدوات المالية، حيز التنفيذ في أغلب الدول الأوربية في

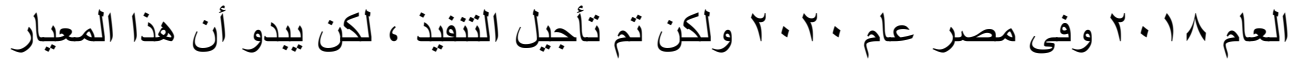
قد لاقى اعتر اضا شديدا مع أول عقبة له في الفصل الأول من العام ، ب . حيث حاولت السلطات المالبة وقف العمل به و إبطال تأثيره في البنوك خلال أزمة جائحة كورونا، على اعتبار أن لهذا المعيار آثار ا سلبية خطيرة على العمل المصرفي خلال فترة الانكماش الاقتصادي، بسبب إجبار المصارف على زيادة المخصصات لخسائر القروض. ولعل قرار العديد من البنوك بإجراء تطبيق الوقف الاختياري لسداد القروض في ظل هذه الأزمة، سيفضي إلى نقص التدفقات النقدية خلال فترة الانكماش الاقتصادي، مدا قد بحدث حالة من الضبابية في الإجراءات المحاسبية الواجب

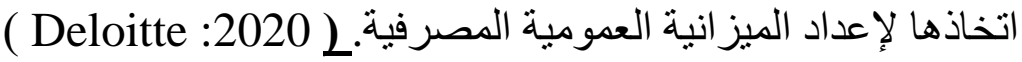
وللعلم فقد سلط منظمو المعايير المحاسبية الضوء على بعض جوانب المرونة في هذا المعيار، (كما هي الحالة مثنلا مع تجنب بعض الآثار الاقتصادية عند وضع نموذج لمخاطر خسائر الائتمان في البنولك )، بهدف تخفيف بعض الانتقادات الموجهة إلبه في بلدان البورو في ظل تفشي هذا الجائحة ، في حين بادرت الولايات المتحدة من خلال 


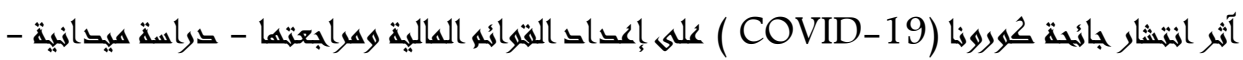
د/ وليخ سمير عبط العظيه الجبلى

المؤسسة الفيدرالية لتأمين الودائع FDIC بتعليق القواعد المحاسبية المتعلقة

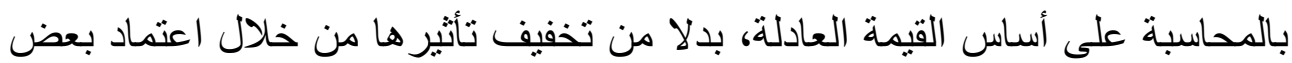
الإجراءات المتخذة في منطقة اليورو والمملكة المتحدة بشأن المعيار

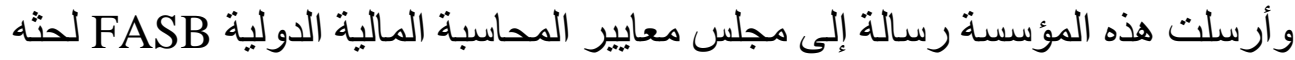

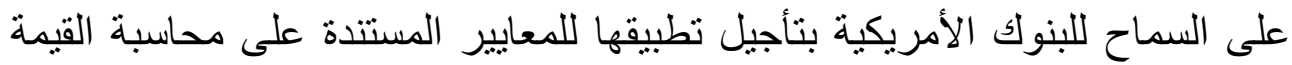

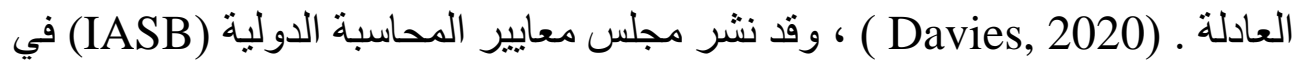

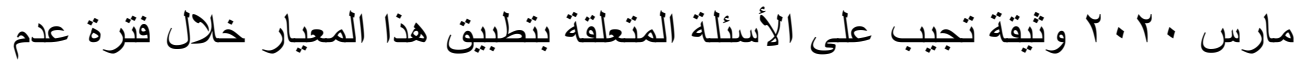
التأكد الناتجة عن الجائحة، وأوضح أن ودئ الغرض من الونة الوثيقة هو دعم تطبيق معايير

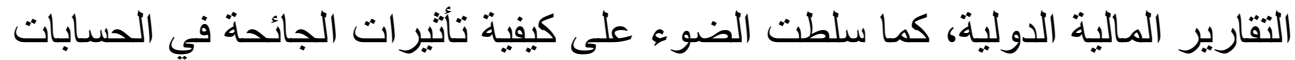

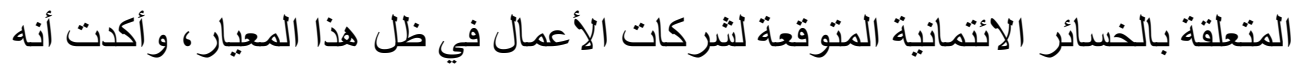

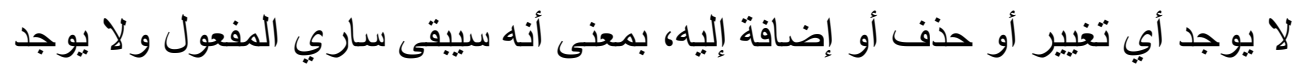
نية لوقف تطبيقه أو تعديل أي من فقر اته ( IFRS, 2020 ) .

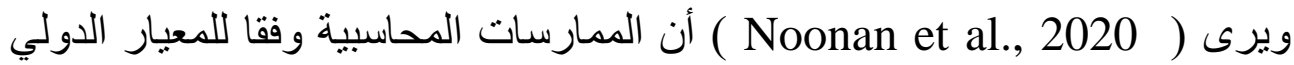
IFRS9

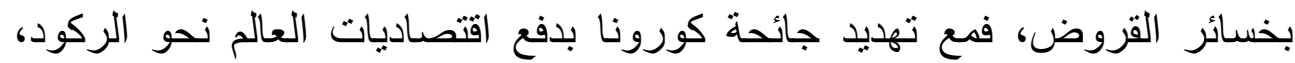
سيعمل المعيار على ترسيخ هذا الركود من خلال جعل المقرضين تهين أكثر عرضئ

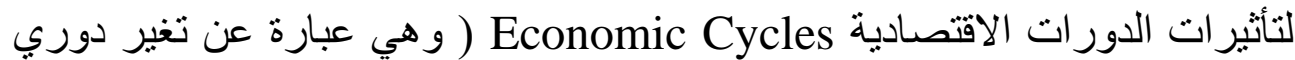
في المؤشرات الاقتصادية كالبطالة والتضخم، وتندرج تحت در اسات الاتهية الاقتصاد الكلي،

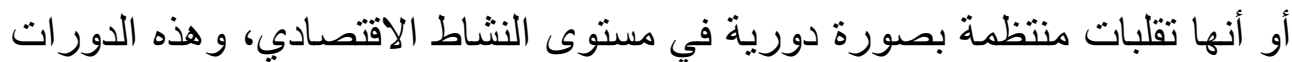

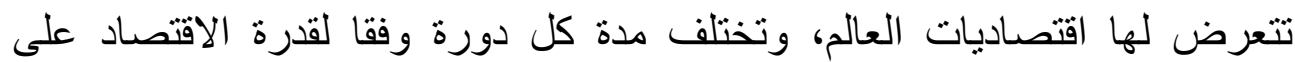

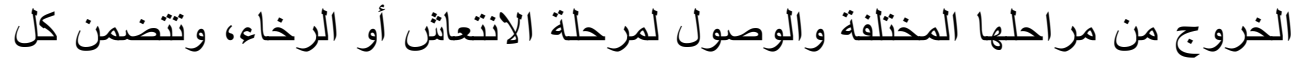

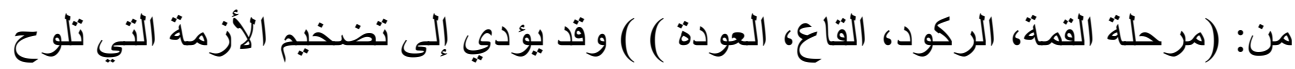
في الأفق بشكل كبير، فعلى سبيل المثال قد تتمثل مشكلة هذه الممارسات في زئل زيادة

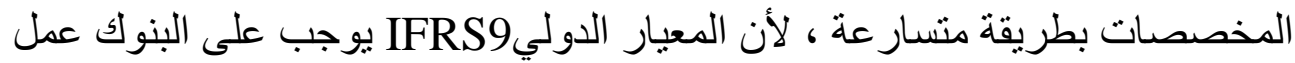

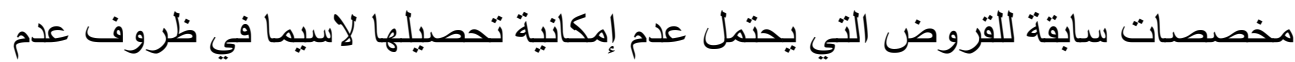




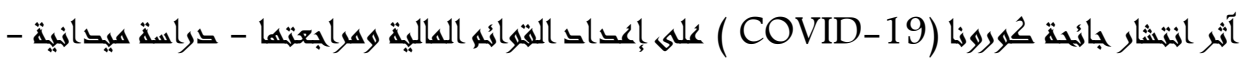
د/ وليد سهير عبد العظيه الجبلمى

التأكد الكبيرة، أو حدوث تغيرات جوهرية في ظروف السوق، وهذا الأمر يجبر

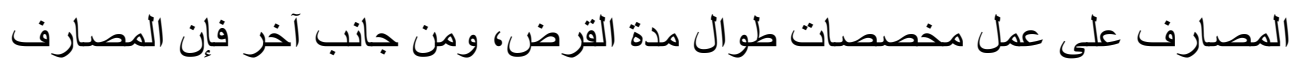

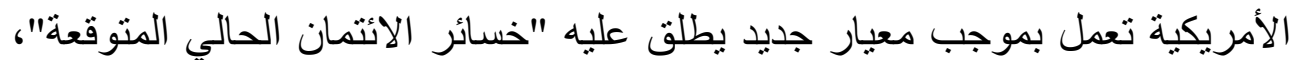

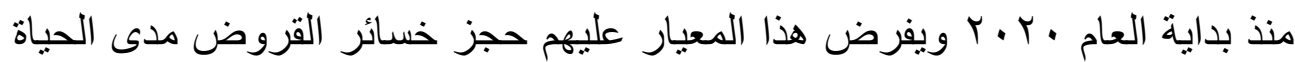

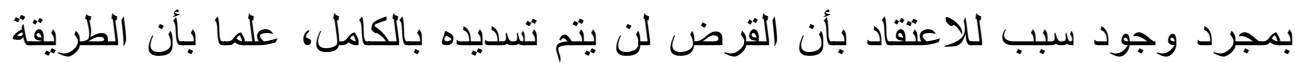

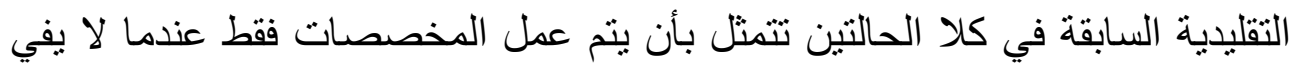

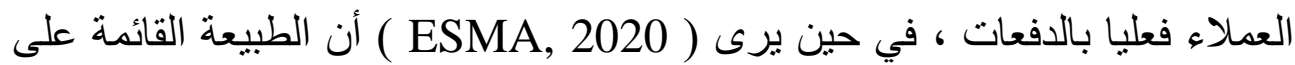
المبادئ للمعيار الدولي IFRS9 مرنة بما فيه الكافية لتعكس بدقة تداعيات تفشي في في

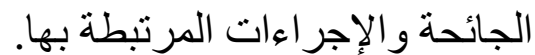

وأخير ا ومن باب التأكيد على جملة هذه التداعيات و الآثار يرى ( Danyluk, 2020

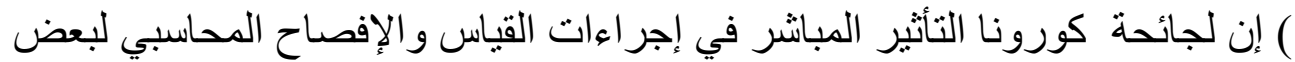

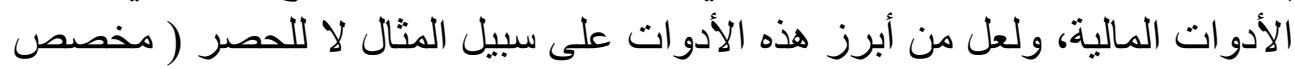

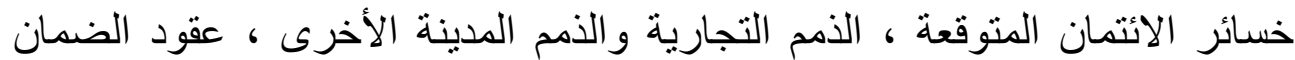

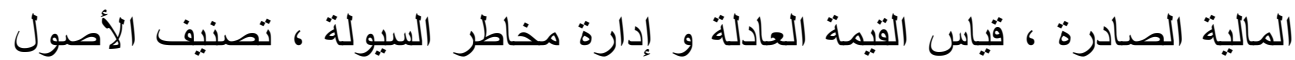
المالية و تعديلات الديون ، التغيرات في التدفقات النقدية المقدرة ، محاسبة التحوط

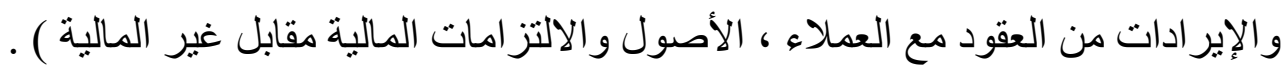

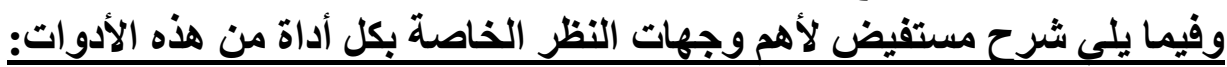

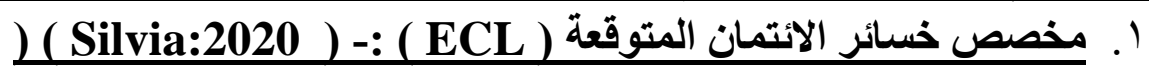

(Ey:2020

لقد فرض المعيار الدوليIFRS9 على شركات الأعمال الأخذ بالاعتبار كافة المعلومات الاقتصادية السابقة والحالية، فضلا عن التولئ التوقعات المستقبلية عند تقييم خسائر الائتمان المتوقعةECL للأصول المالية التي لا يتم قياسها بالقيمة العادلة ، و و

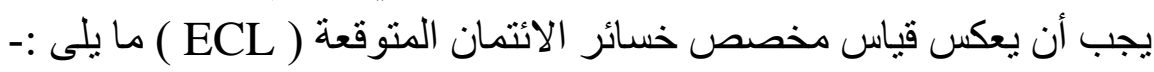
القيمة الزمنية لوحدة النقد فين محصن 


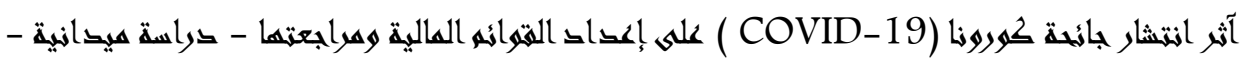
د/ وليد سهير عبد العظيه الجبلمى

معلومات معقولة وداعمة حول الأحداث الماضية ، و الظروف الحالية

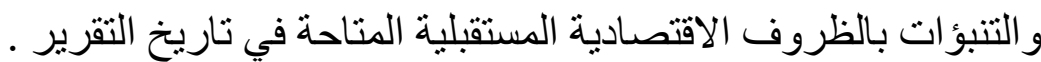

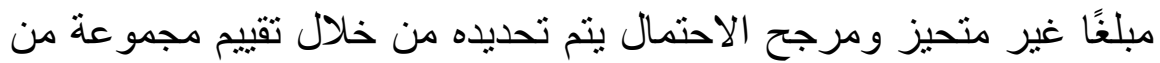

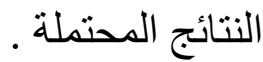

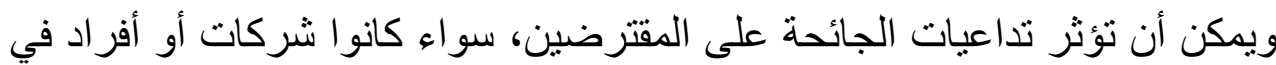

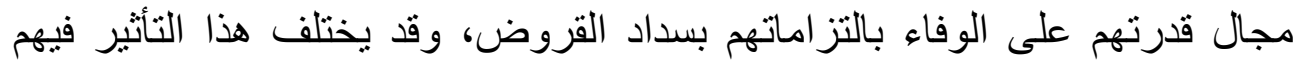

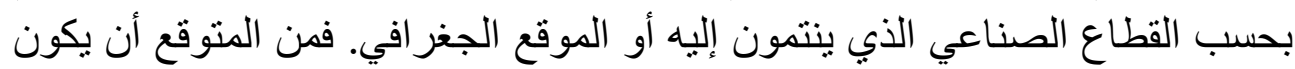

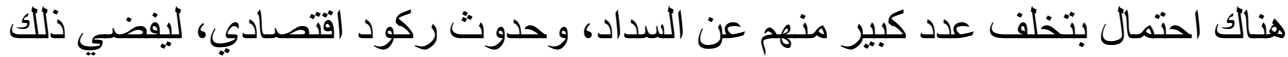

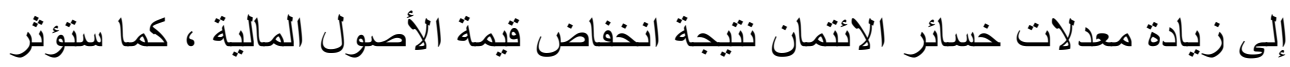

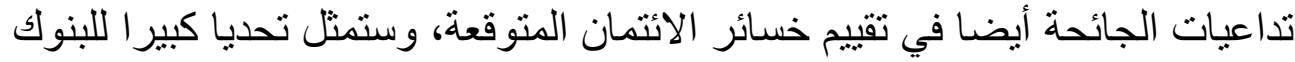
و غير ها من شركات الإقراض وحتى الثركات المالية، بسبب أن خسائر الائتمان

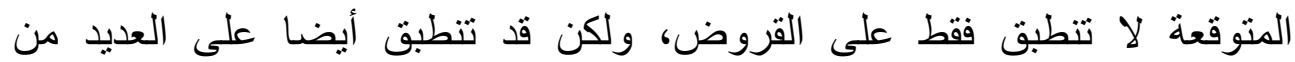

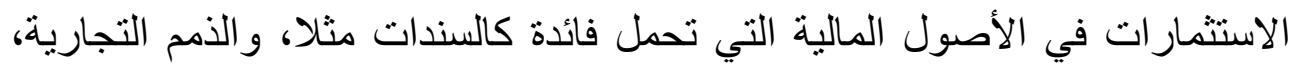

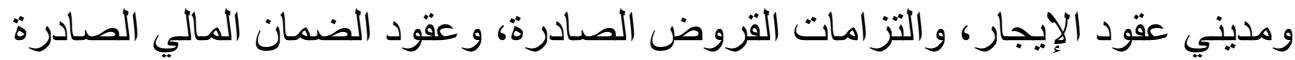

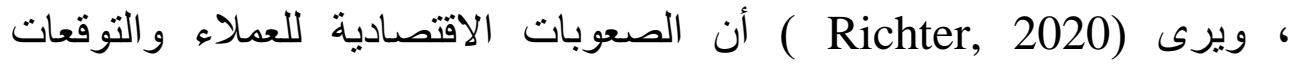
الاقتصادية السلبية بشكل عام ستعمل بشكل كبير على زيادة مخصص الخسائر

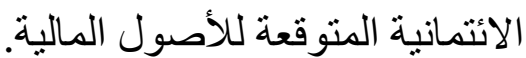

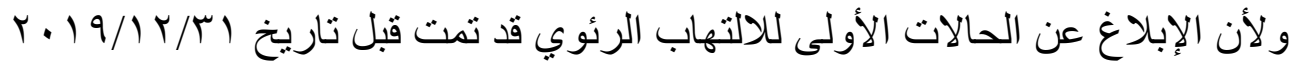
وأن المعيار الدوليIFRS9 يوجب الأخذ بكل التوقعات الخاصة بالظروف لإن الإتصادية المستقبلية على أساس الاحتمال المرجح، لذا يتوجب على الثركات تقات القييم احتمالية وقوع الضرر المتوقع من الجائحة في ذلك التاريخ إذا كان سيؤثر بشكل كبير في التئي

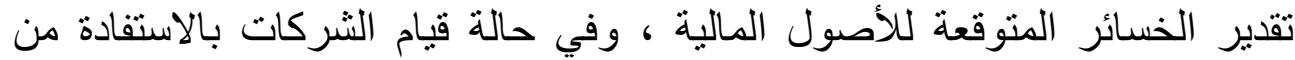

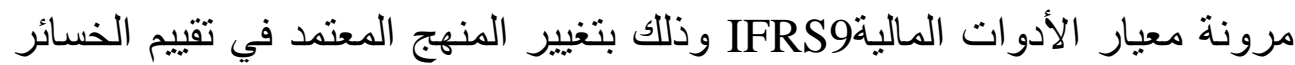

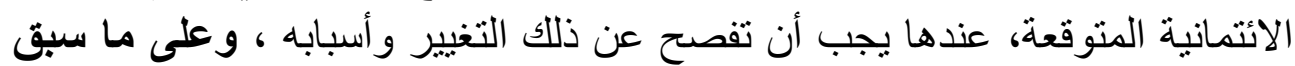
يرى الباحث: :- (اليه 


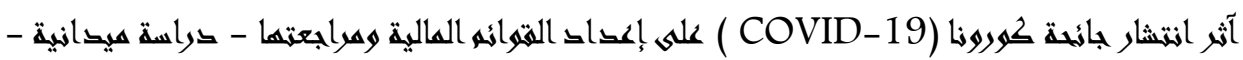
د/ وليد سهير عبد العظيه الجبلمى

ل في حالة السماح لجميع المقترضين في فئات معينة من الأدوات المالية بتأجيل

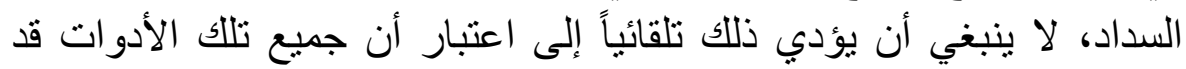

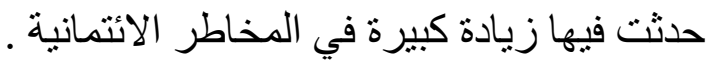

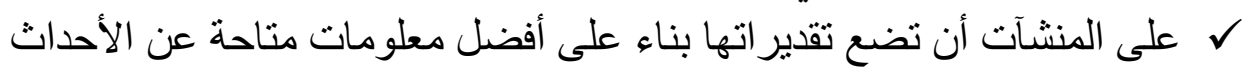

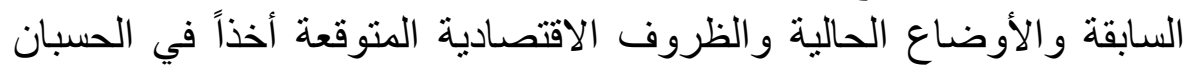

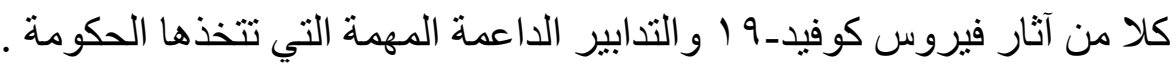
Y. الأمم التجارية والأمم المدينة الأخرى :-ـ ( Deloitte ) ( IFRS : ( :2020

فيما يخص الشركات التي لديها أصول مالية معينة كالذمم التجارية المدينة قصيرة الأجل، فإن تقدير خسائر ها المتوقعة لن يكون بنفس مستوى التعقيد عند تقدير الخسائر

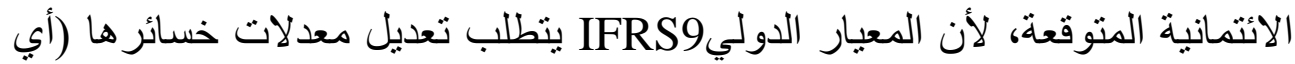
خسائر هذه الذمم ) التاريخية بحسب الحاجة لتعكس الظروف التهارئ الحالية وتقديرات

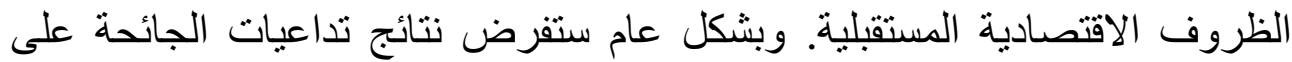
الثركات إعادة النظر في أسلوب احتساب وتكوين المخصصات من خلال النظر عاد بكل ما يليى :-

سوف تحتاج الثركات إلى إعادة النظر في توقعات خسائر الائتمان السابقة إذا ما

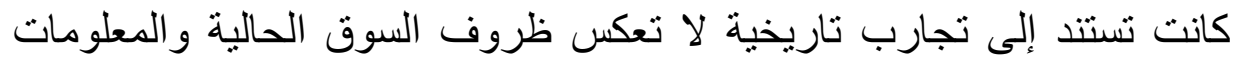

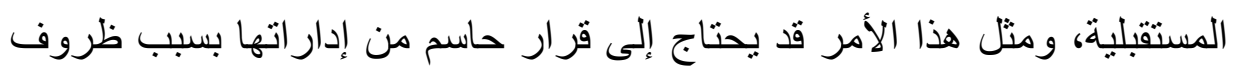

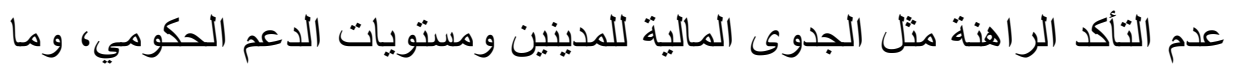
إلى ذلك.

قد يكون هناك نقص في البيانات التاريخية الملائمة التي تعكس الظروف الاقتصادية التي يستند إليها عند تقدير الخسائر ، كما قد يؤدي عدم الاستقرار

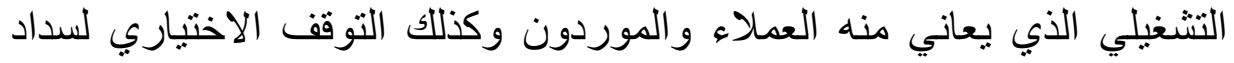

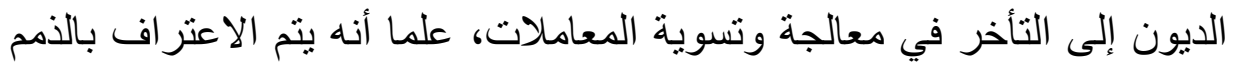
المدينة التجارية قصيرة الأجل بسعر المعاملات، ومن ثم يكون لها معدل فائدة 


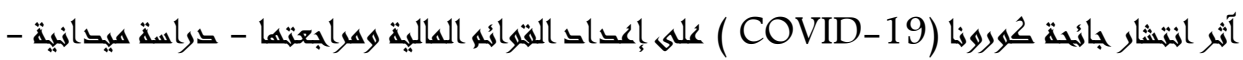
د/ وليخ سمير عمب العظيه الجبلمى

فعلي صفري، و عليه فإن التأخر في التحصيل لن يؤدي إلى زيادة في مخصص الخسارة المبلغ عنه. >

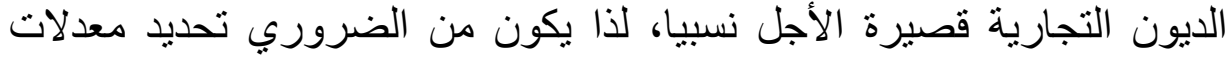

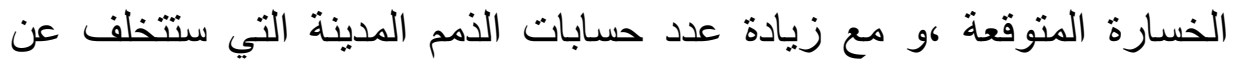

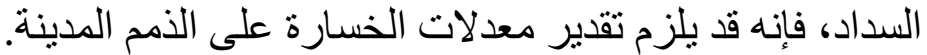
ويرى ( KPMG, 2020 ) أنه عند بداية تفشي جائحة كورونا في كانون الأول من فئل

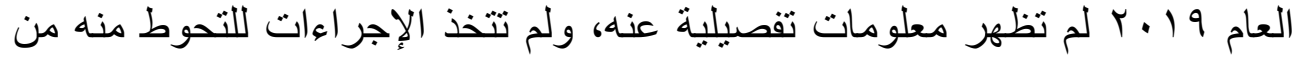

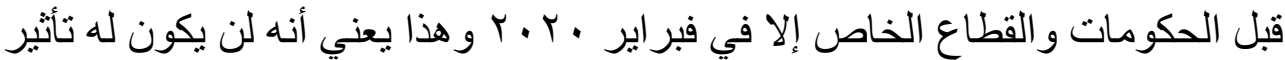

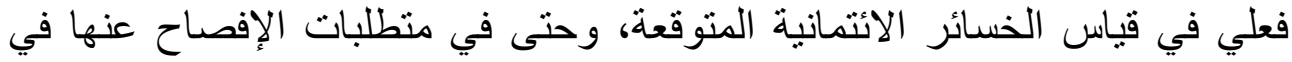
$r \cdot 19 / \mid r / T_{1}$

أما الأمم المدينة الأخرى: ستحتاج الثركات إلى إعادة النظر في مدى ملائمة

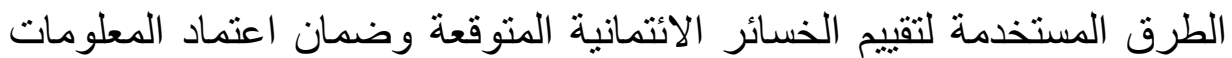

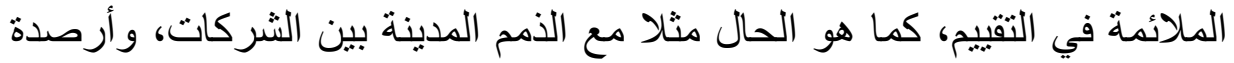

$$
\text { الإقر اض مع شركات أخرى. }
$$

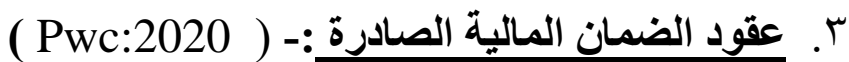

قد تصدر شركات الأعمال القابضة أو الثركة الأم أحيانا عقود ضمان مالية

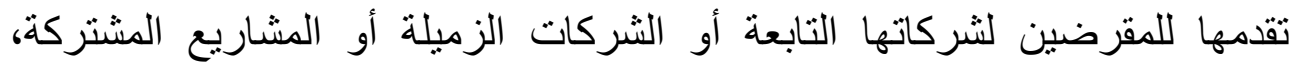
وتسمح بمقتضاها لمن أقرضهم بالمطالبة بالخسائر التي تكبدوها نتيجة عدم دفع هذه

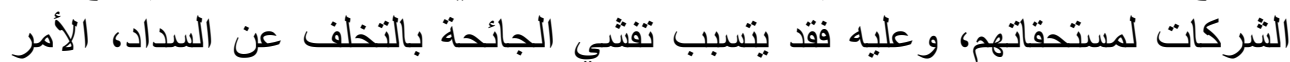

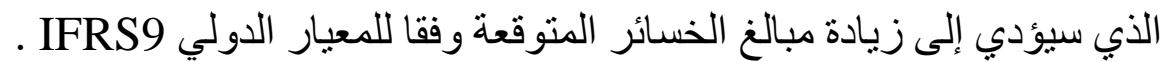

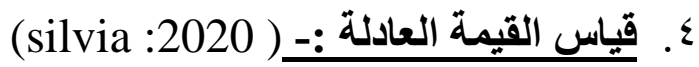

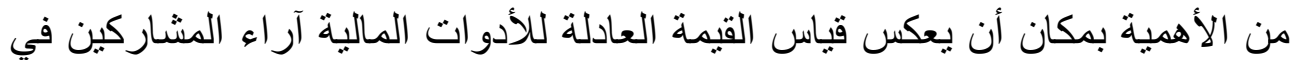

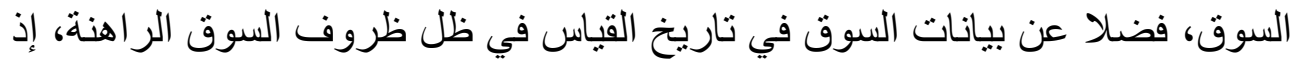

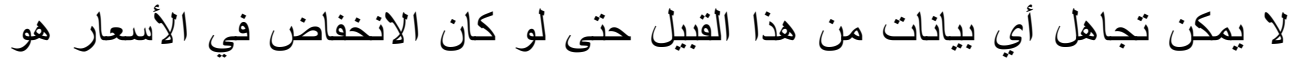




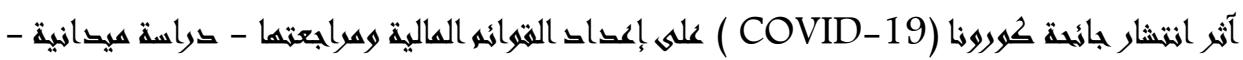
د/ وليق سمير عبد العظيه الجبلى

انخفاضا مؤقتا، وفي كل الأحو ال ستهتم الشركات بشكل خاص بقياسات القيمة العادلة،

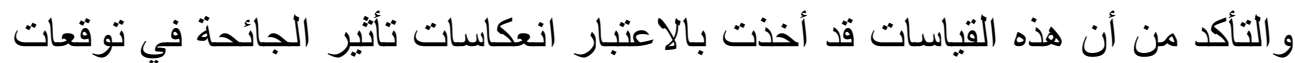

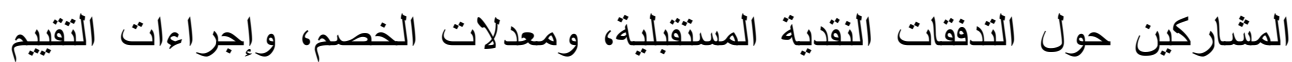

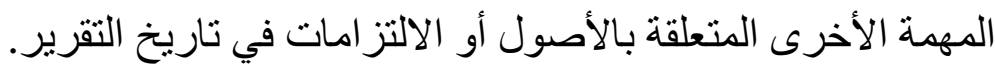

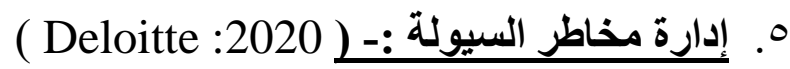

من المحتمل جدا أن يكون للتوقف عن الإنتاج وانخفاض اله المبيعات آثار على رأس

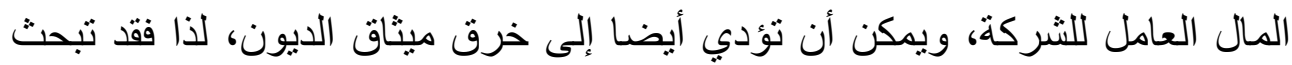

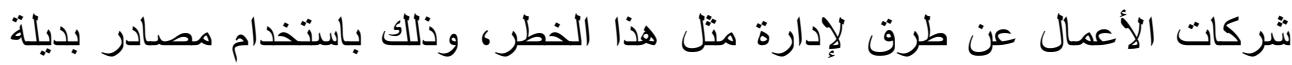

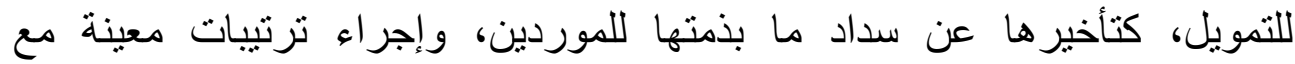

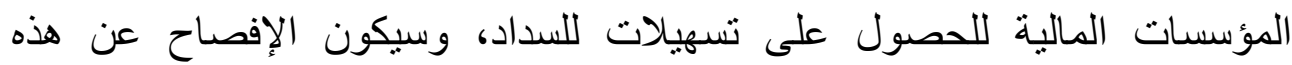
التسهيلات في غاية الأهمية لا سيما عندما تكون جوهرية لتمويل الثركة أو تمنحها

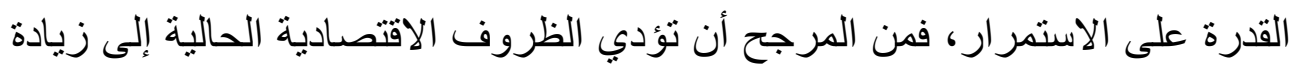

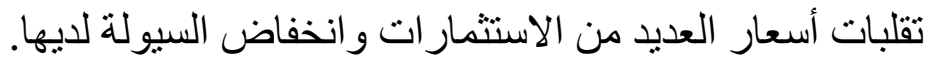
7. تصنيف الأصول المالية :-ـ ( silvia : 2020)

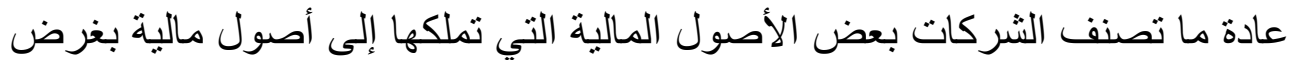

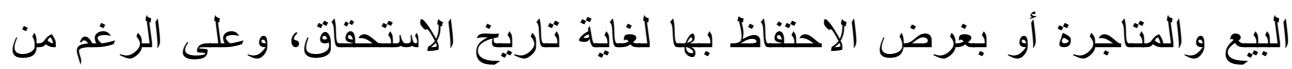

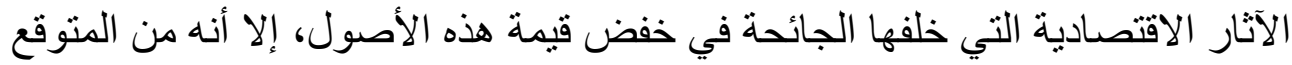

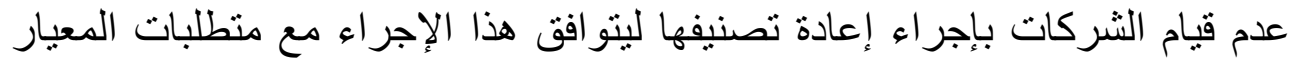

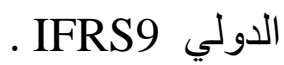

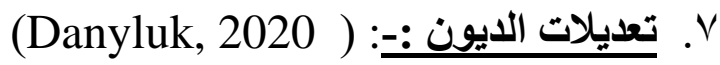
استجابة لتحديات السيولة، فقد يسعى المدينون إلى إعادة التفاوض الته على شروط ترتيبات السداد مع الثركة، و عندما تمنح الأخيرة مثل هذا الامتياز وتجري التعديل

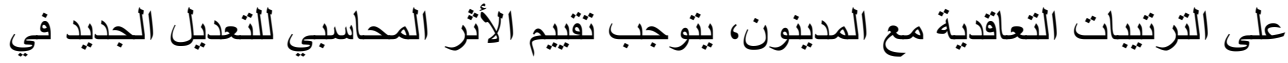

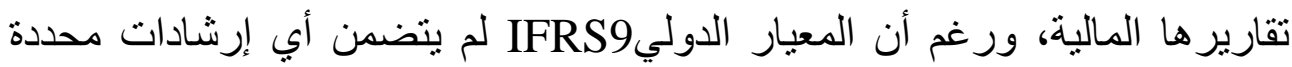
بثأن المحاسبة عن تعديلات الأصول المالية، ومتى يجب أن تؤدي هذه التعديلات إلى الى الى 


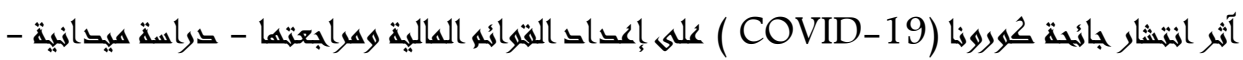
د/ وليخ سمير عمب العظيه الجبلمى

إلغاء الاعتر اف بها، إلا إن بعض الثركات تلجأ إلى اعتماد سياسات محاسبية خاصة

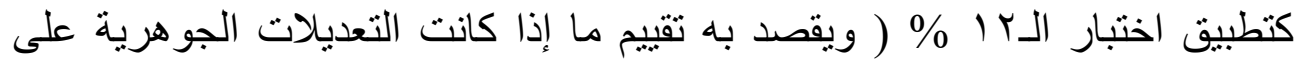

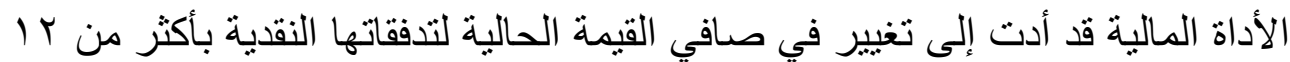

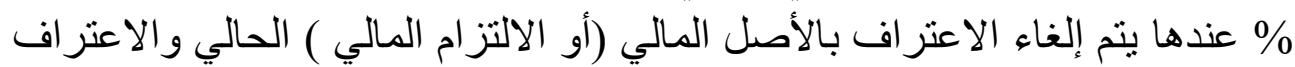

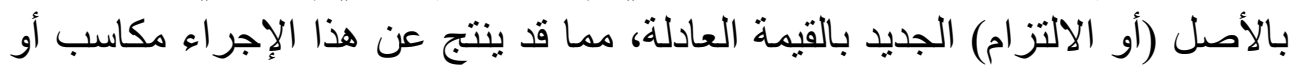
خسائر.

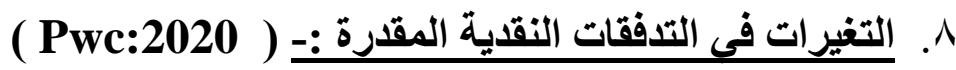

من التداعيات التي نتجت عن جائحة كورونا التغير في التوقعات المتعلقة بممارسات

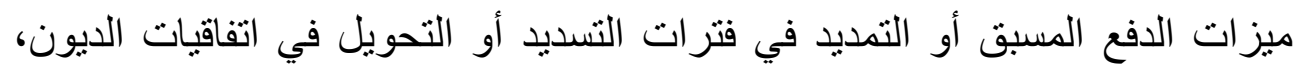

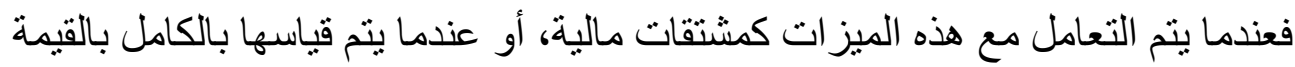
العادلة، فسينعكس هذا التغير من دون شك في في قياس هذه القيمة، وسيتم خصم التدفقات

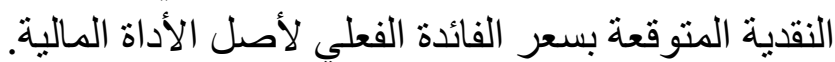

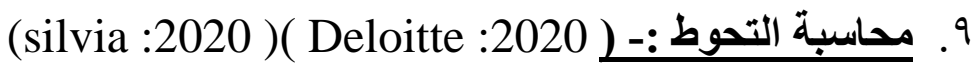

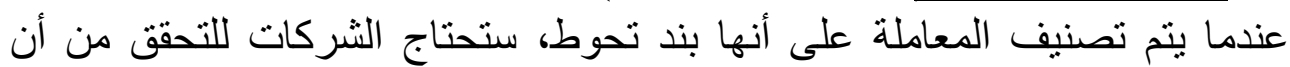

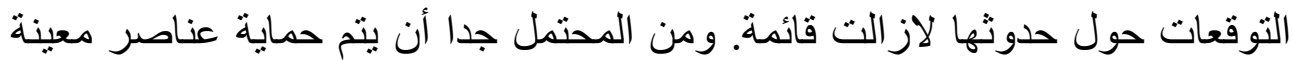

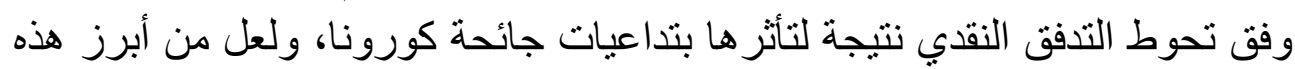

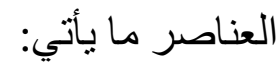

ل أحجام البيع أو الثراء التي تقل عن المستويات المتوقعة.

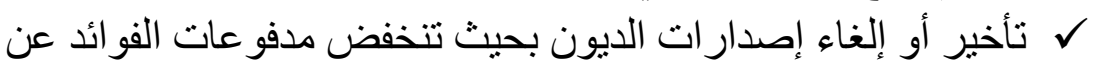
المستو يات المتوقعة منها. ل عمليات الاستحو اذ أو المعاملات منهات التجارية المتأخرة أو الملغاة.

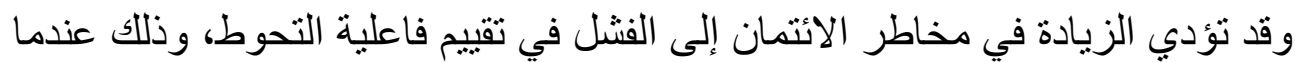
تكون مخاطر الائتمان مهيمنة على تغير ات القيمة الناتجة عن العلاقات الاقتصادية بين الأني أداة التحوطو البند المحوط. 


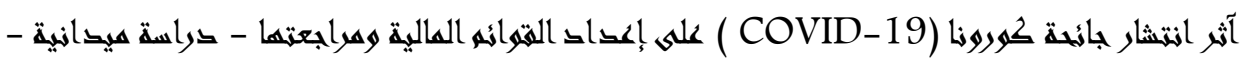
د/ وليد سهير عبد العظيه الجبلمى

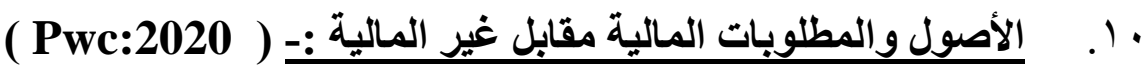

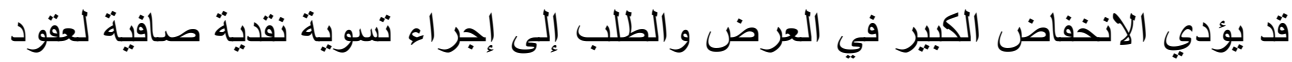

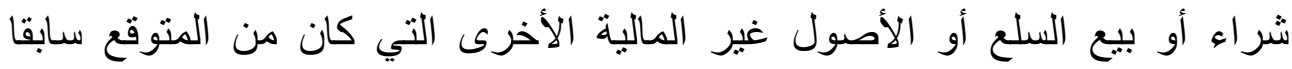

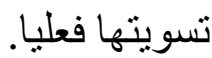

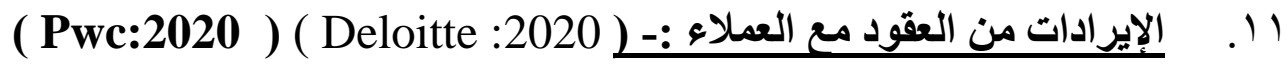

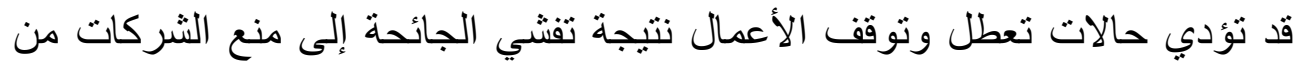

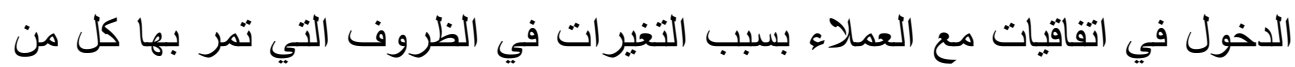
الشركة و العميل، عليه فقد تحتاج الثركة إلى مر اعلى التهاة عو امل معينة عند تقييم إير اداتها

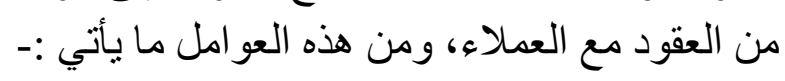

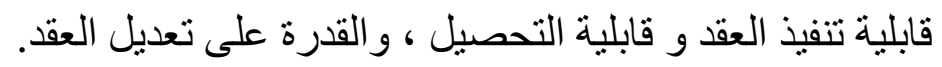

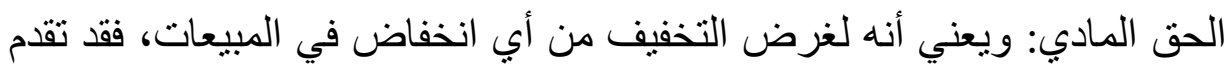

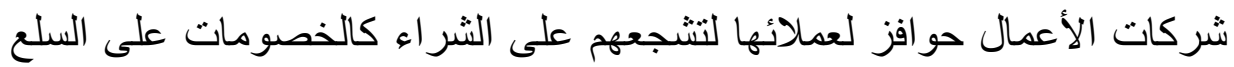

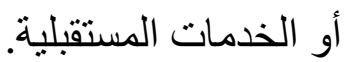

الاعتر اف بالإير ادات: ويعني أنه قد تحتاج الثركات بسبب الانقطاعات المحتملة

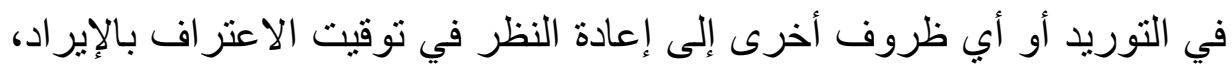

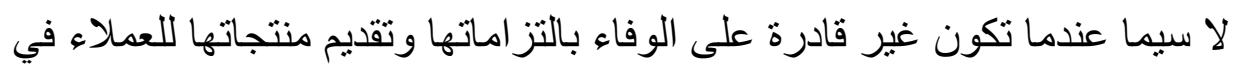

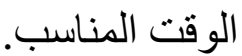

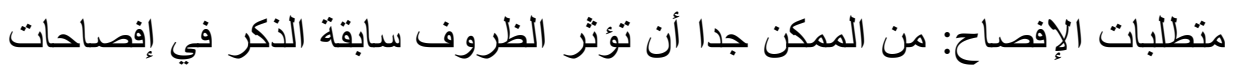

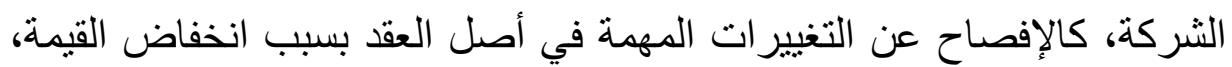

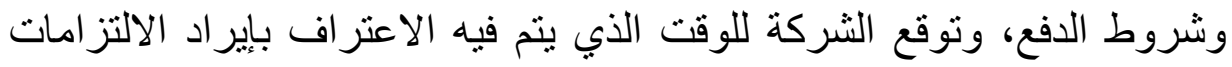

المتبقية لها.

المحور الثالث :- تداعيات أزمة كرونا COVID-19 على مراجعة القوائم المالية

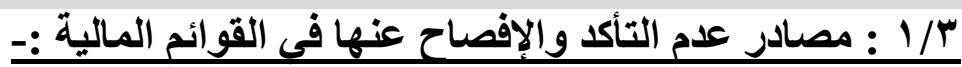

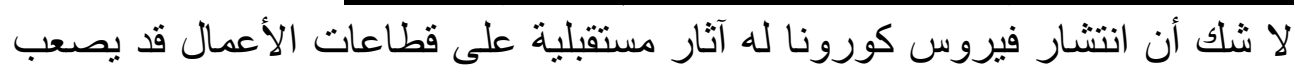

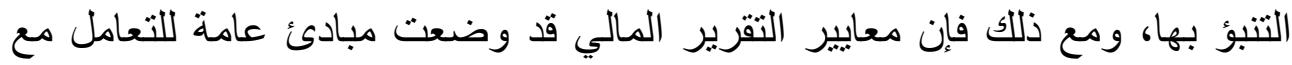




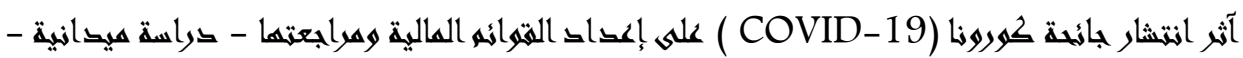
د/ وليق سمير عبد العظيه الجبلى

حالات عدم التأكد. وبشكل محدد، ينص معيار المحاسبة الدولي(IAS 8) " السياسات

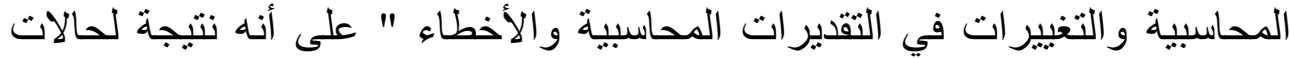

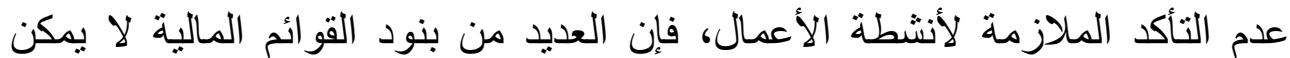

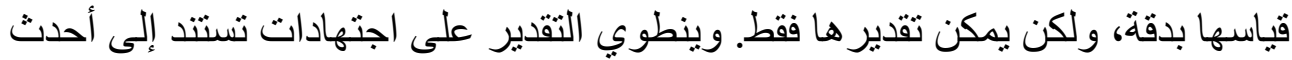

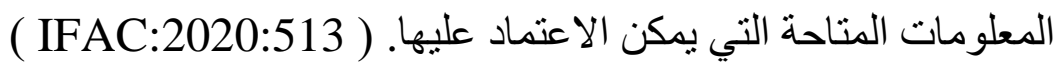

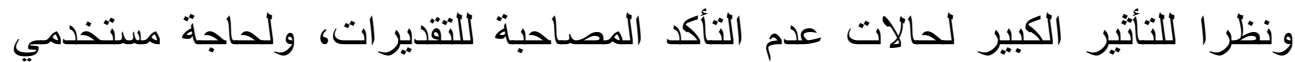

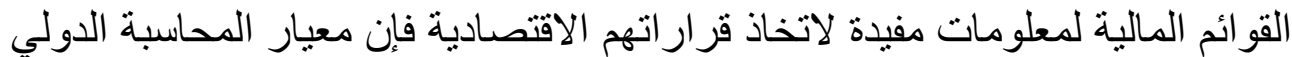
(IAS1)

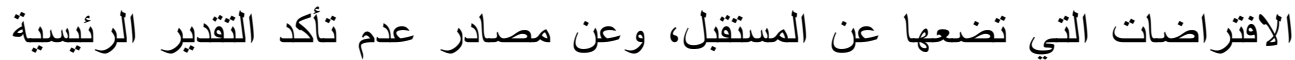
الأخرى في نهاية فترة التقرير، و التي لها مخاطر مهمة قد ينتج عنها تعديل ذو أهمية

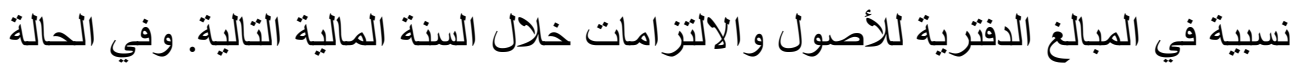
الراهنة لانتشار فيروس COVID-19 فإن تحديد المبالغ الدفترية لبعض الأصول

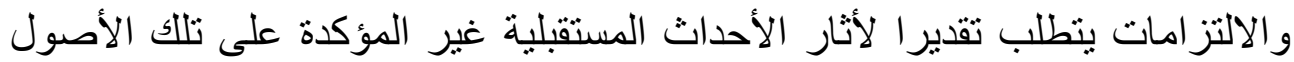

و الالتز امات في نهاية فترة التقرير، و التي قد يسببها هذا الوباء. ( ASIC:2020 )

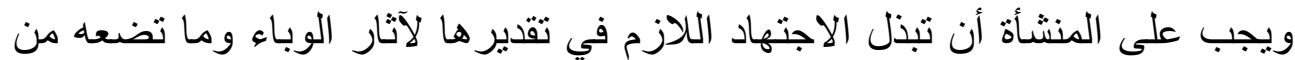

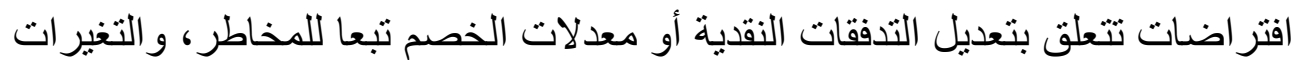

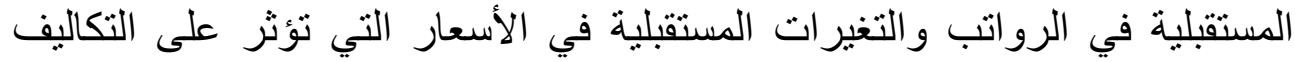

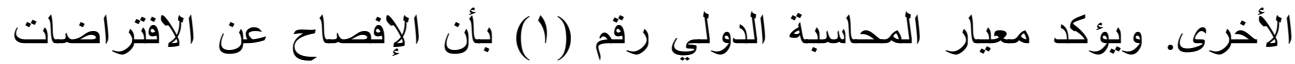

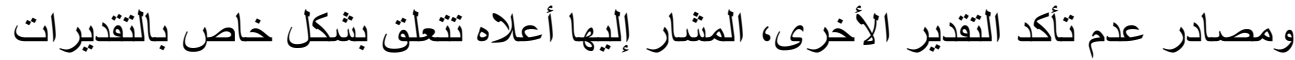

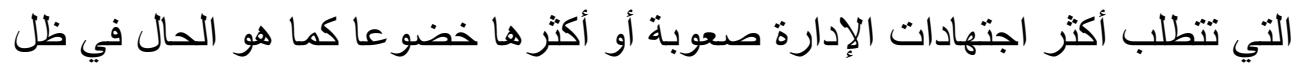

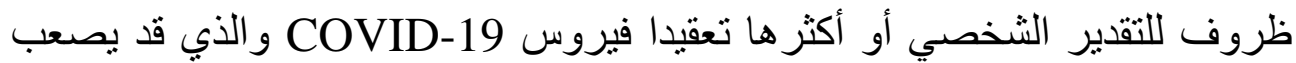
التنبؤ بنهايته ومدى شدة آثاره. ( Bader :2020:p6 ) ) ، ويؤكد المعيار على أنى أنه كلما

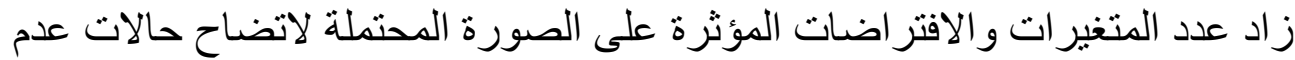

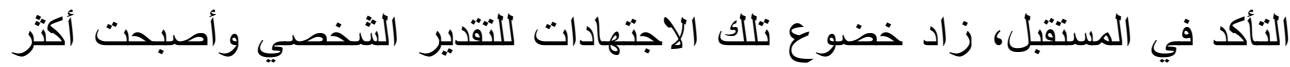
تعقيدا ومن ثم ، زادت عادة إمكانية أن ينجم عن ذلك تعديل ذو أهمية نسبية على الهي 


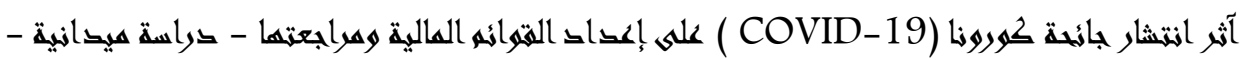
د/ وليخ سمير عمب العظيه الجبلمى

المبالغ الدفترية للأصول و الالتز امات ، و عليه فإن الباحث يوصي معدي القو ائم المالية

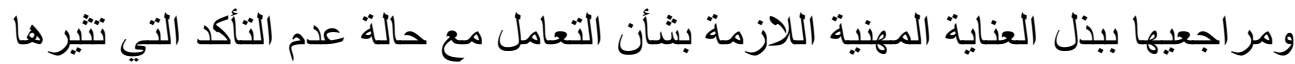
ظروف فيروس كوفيد- ،9 اوتقديم الإفصاحات اللازمة لمساعدة مستخدمي القوائم المالية على اتخاذ قرارات اقتصادية رشيدة مبنية على معلومات ذاتلفيمات ذات جودة عالية.

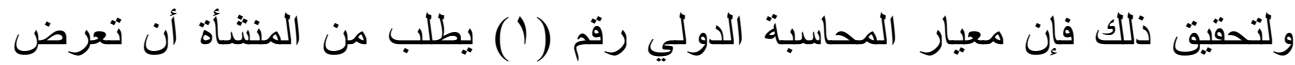

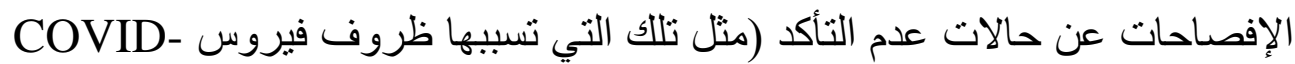
19) بطريقة تساعد مستخدمي القوائم المالية على فهم الاجتهادات التي تمارسها

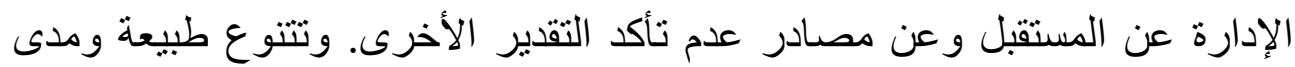

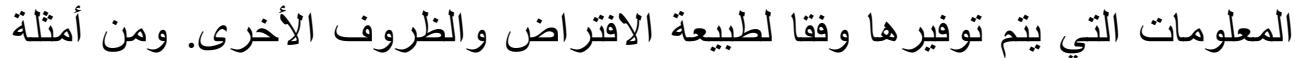

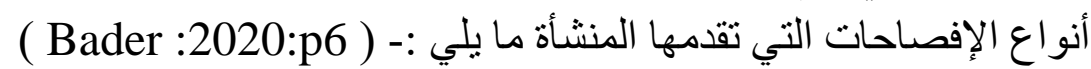

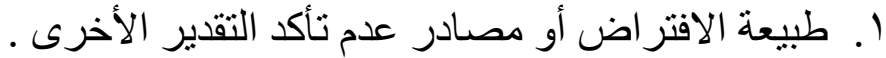

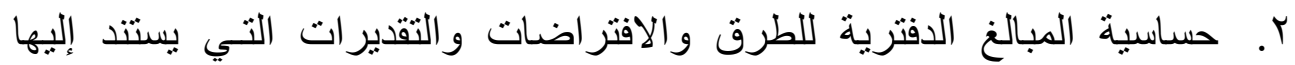

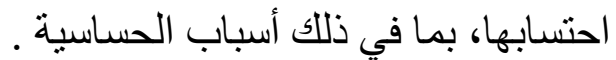

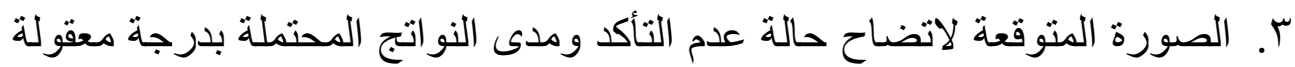

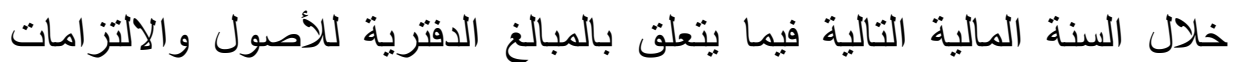
المتأثرة

ع. شرح للتغييرات التي تم إدخالها على الافتر اضات السابقة بشأن تلك الأصول

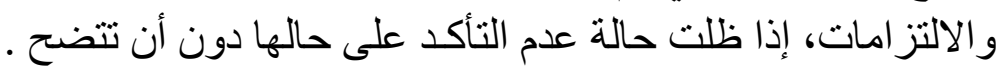

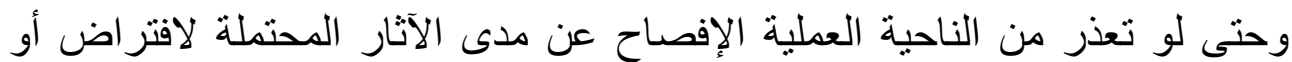

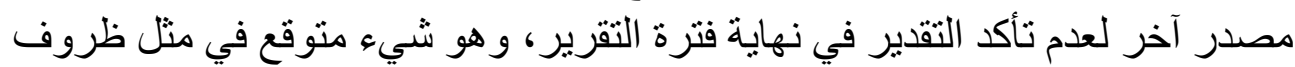

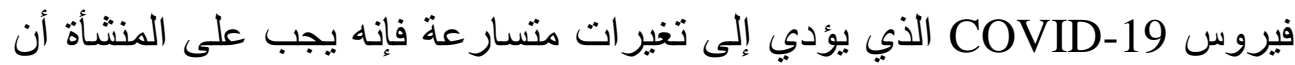

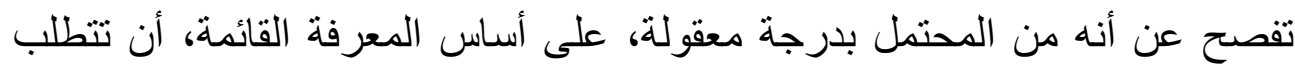

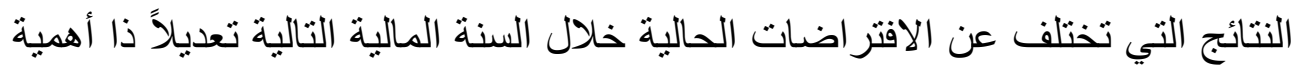
نسبية على المبلغ الدفتري للأصل أو الالتزام المتأثر. وفى جميع الحالاته التهن تفصح 


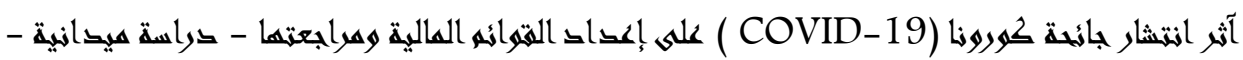
د/ وليق سمير عبد العظيه الجبلى

المنشأة عن طبيعة الأصل أو الالتز ام المحدد (أو فئة الأصول أو الالتزامات) المتأثز

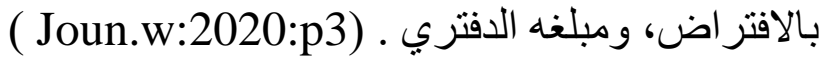

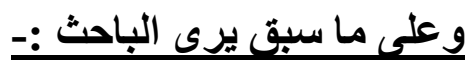

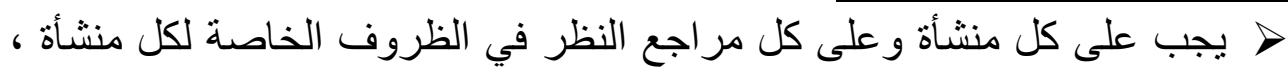

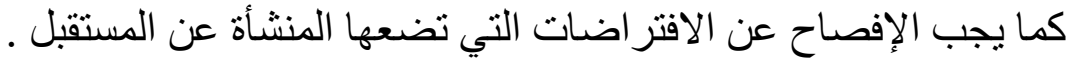
COVID-19

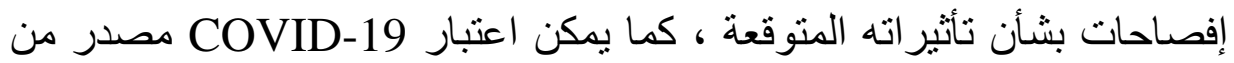

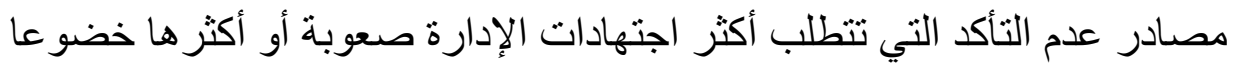

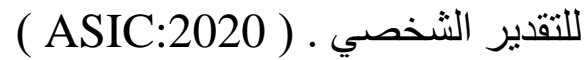

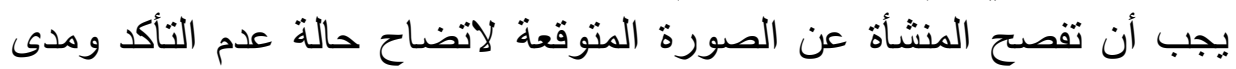

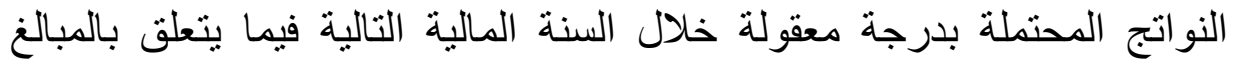
الدفترية للأصول و الالتز امات المتأثرة .

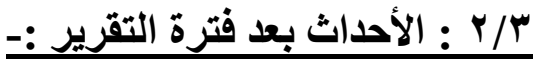

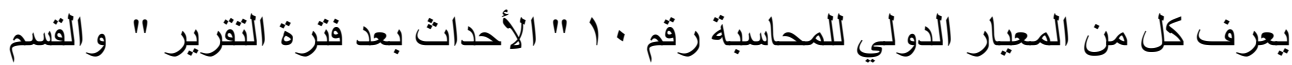

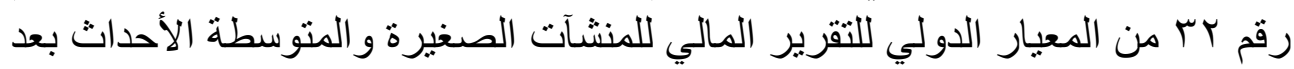

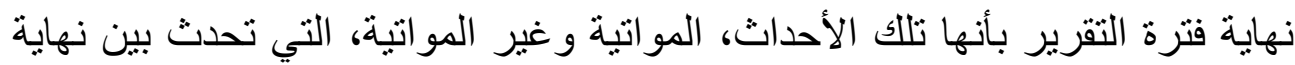

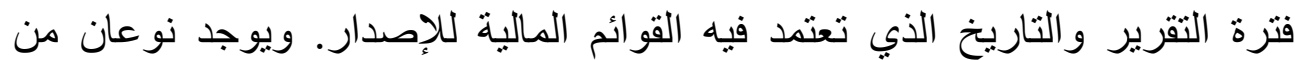

(IFAC:2020:555 ) - الأحداث

ا. تللك التي توفر دليلاً على ظروف كانت موجودة في نهاية فترة التقرير (أحداث بعد نهاية فترة التقرير تتطلب تعديلات ) . r. تللك التي تشير إلى ظروف نشأت بعد نهاية فترة التقرير (أحداث بعد نهاية فترة

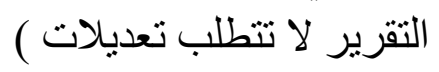

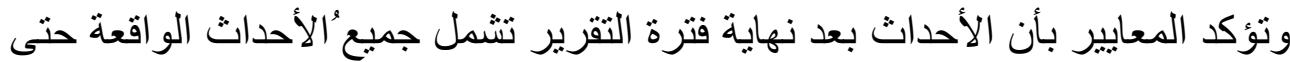

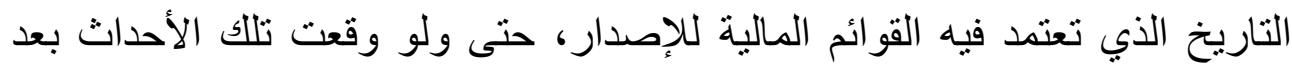

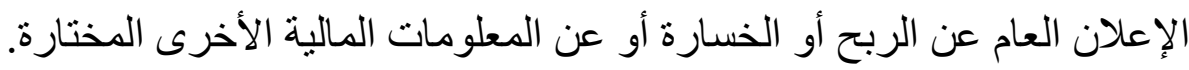




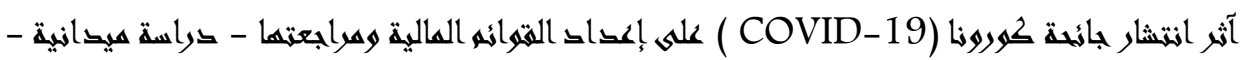
د/ وليد سهير عبد العظيه الجبلمى

و عليه فإن على كل منشأة عند إعداد قو ائمها المالية أن تنظر في التأثنير ات المصاحبة

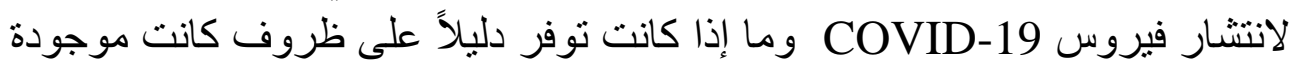

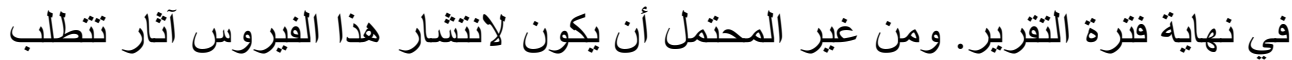

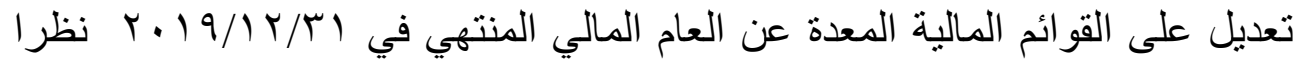
لأنه في ذلك التاريخ لم يكن هناك أثر على اقتصاد العالم بشكل عام، وعلى ولى ألى أعمال

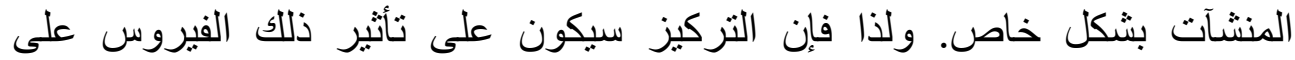

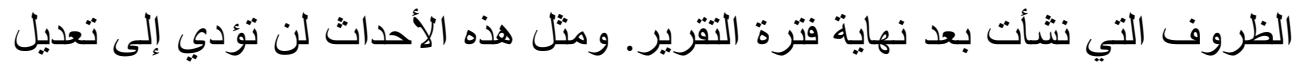

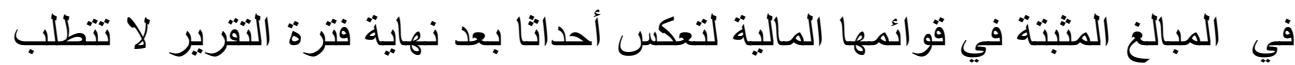
تعديلات.

ومما يحسن التذكير به أنه من المهم أن توفر المنشأة إفصاحات كافية عن الآثار المحتملة لفيروس COVID-19 إذا كانت ذات أهمية نسبية بحيث تساعد القوائم المالية المستفيدين على اتخاذ قرارات مدروسة وفقا للمعلومات المتاحة. ويطلب

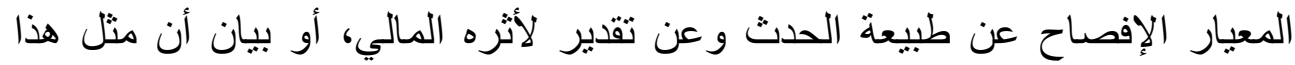

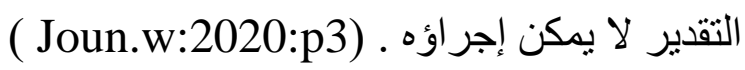

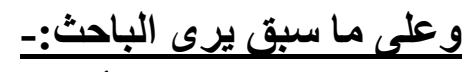

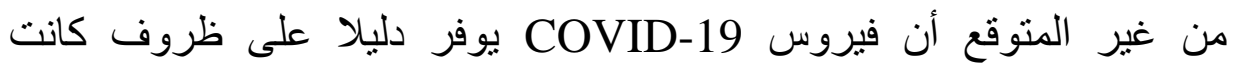

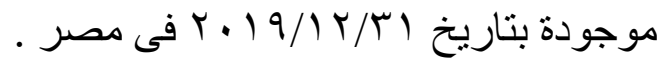

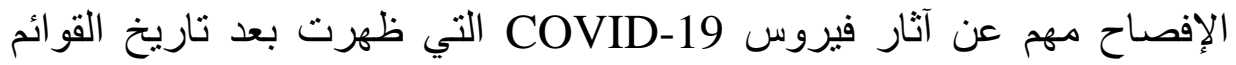
المالية وقبل اعتمادها للنشر عنم الإفصاح ضروري حتى مع عدم القدرة على تقدير الأثر المالي لفيروس كوفيد.19

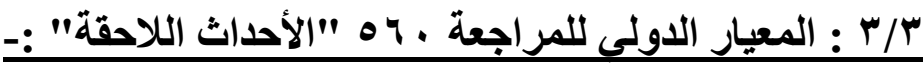

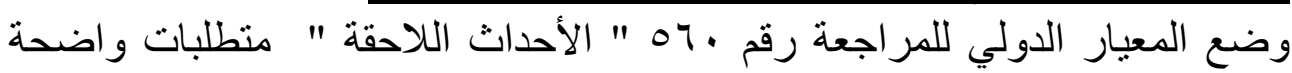

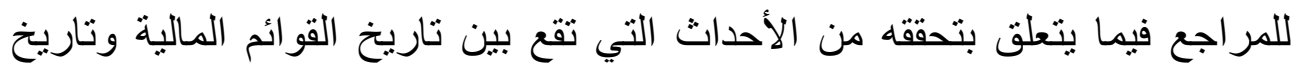
تقرير المر اجع. إلا أن ما يلزم التأكيد عليه في هذه النشرة المتطلبات المتعلقة بالحقائق 


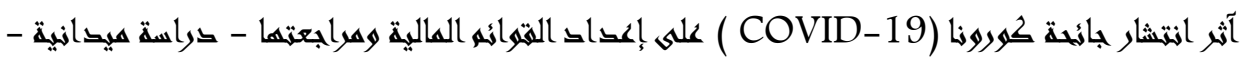
د/ وليخ سمير عبط العظيه الجبلى

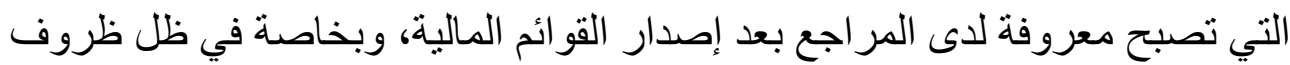
فيروس COVID-19 وما تسببه الإجراءات الاحتر ازية المقيدة للحركة من إمكانية

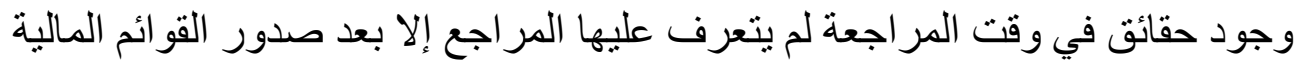

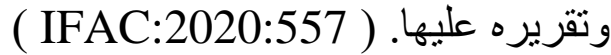

وفي مثل هذه الحالة يطلب المعيار من المراجع عندما يعلم بحقيقة ما بعد إصدار

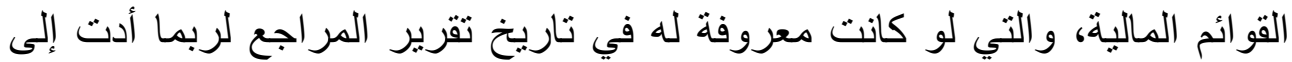

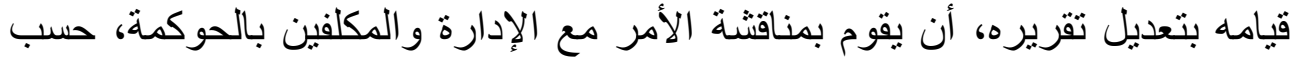

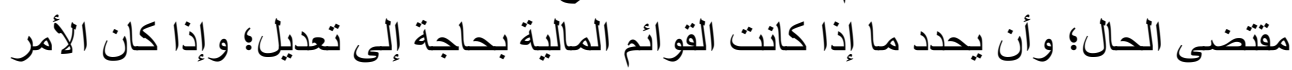
كذلك الاستفسار عن الكيفيـة التي تعتزم بها الإدارة معالجة الأمر في القو ائم المالية.

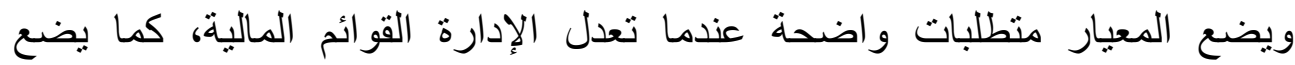
منطلبات في حالة لم تقم الإدارة بالتعديل اللازم للقوائم المالية. و يهيب الإداء الباحث

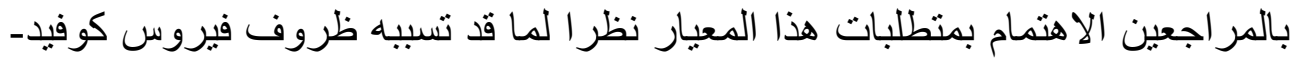

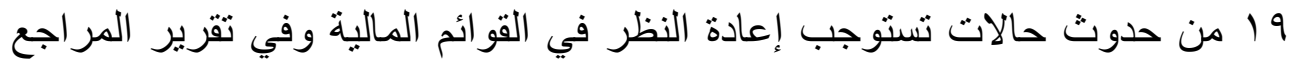

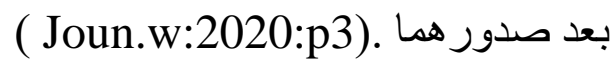

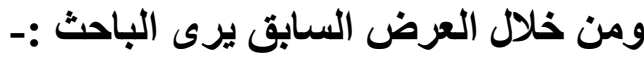
من المخاطر المصاحبة لفيروس COVID-19 إمكانية وجود حقائق بعد صدور

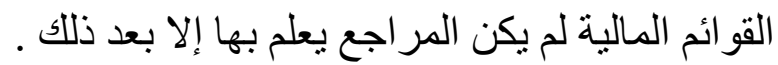

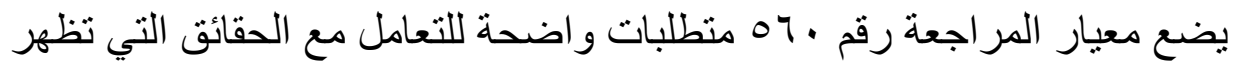
بعد صدور القوائم المالية.

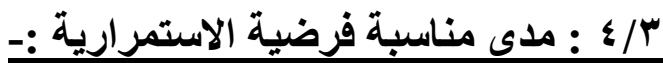

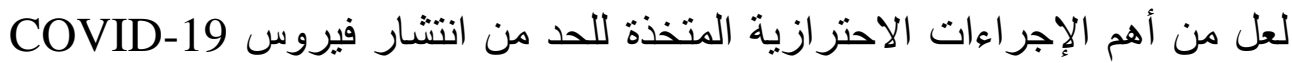

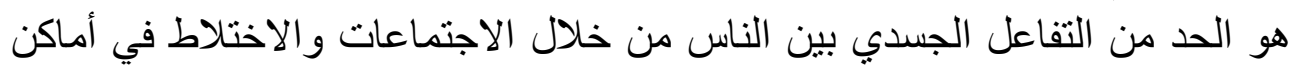

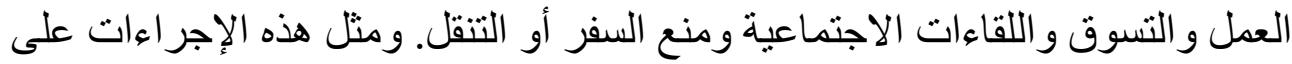

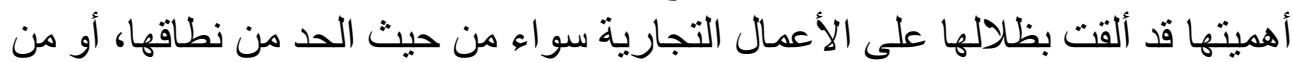
حيث تقلص الطلب على المنتجات، مما قد يثير شكاً حول قدرة المنشأة على البقاء 


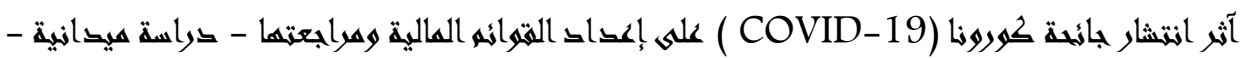
د/ وليد سهير عبد العظيه الجبلمى

كمنشأة مستمرة. وبالمقابل قدمت الدولة عددا من التسهيلات و الدعم للأعمال التجارية

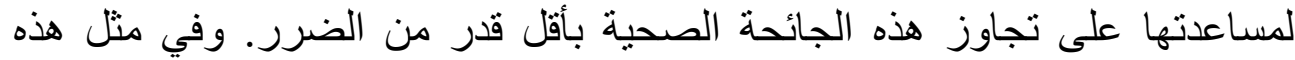
الظروف يثور التساؤل حول كيفية التعامل مع فرضية استمرارية المنشأة والآثار

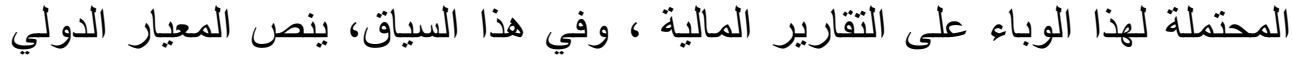

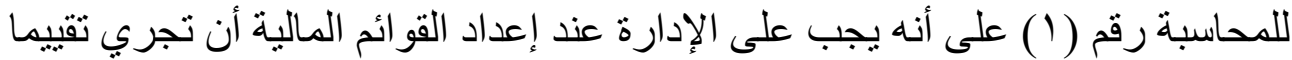

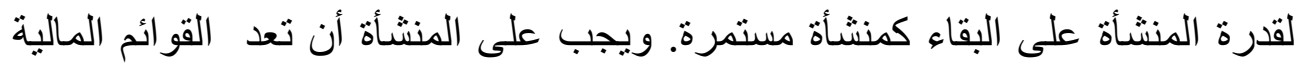
على أساس الاستمرارية ما لم تكن هناك نية لدى الإدارة لتصفية المنشأة أو إيقاف

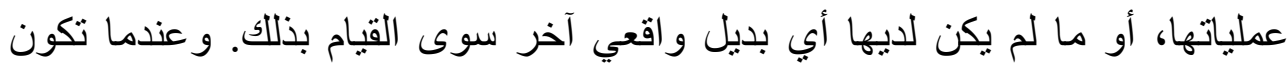

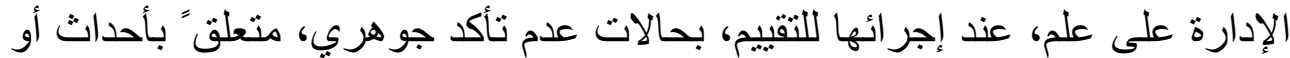

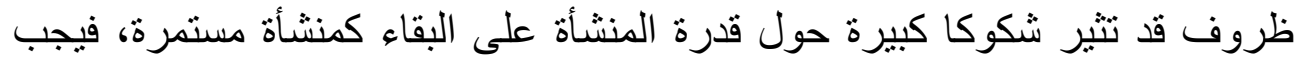
على المنشأة أن تفصح عن حالات عدم التأكد تلك. و وعندما لا تعد المنشأة القو ائم المالية

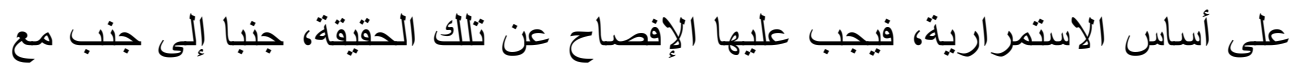
الأساس الذي أعدت عليه القوائم المالية، وسبب أن المنشأة لا تعد منشأة مسنمرة.

( IFAC:2020:511)

كما يطلب نفس المعيار من الإدارة عند تقييمها لما إذا كان افتر اض الاستمر ارية يعد

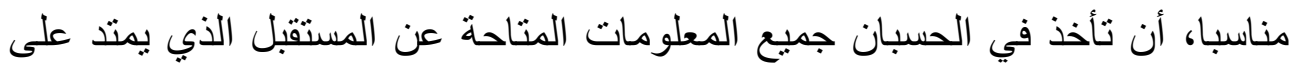

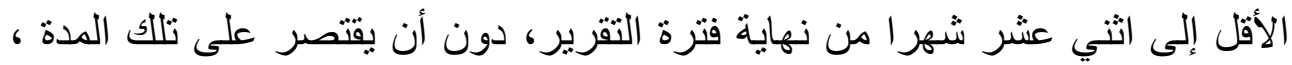

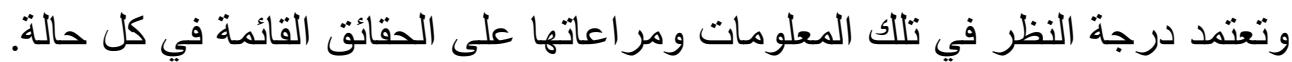

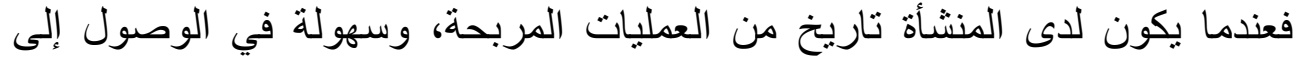

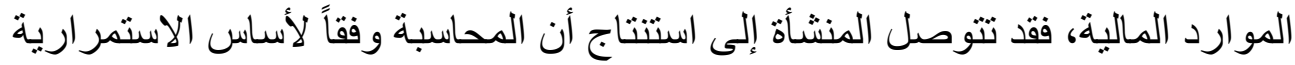

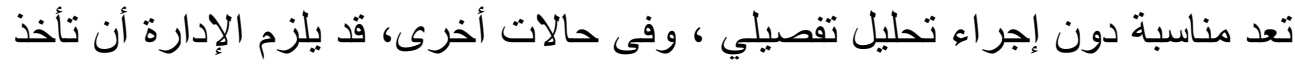

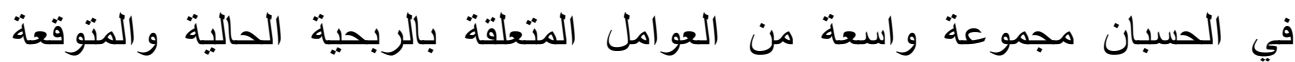

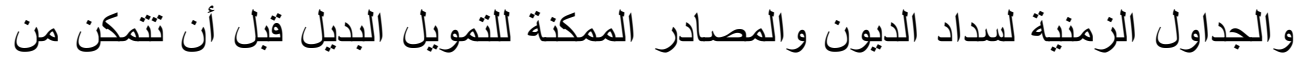
التوصل إلى قناعة بأن أساس الاستمر ارية يعد مناسباً . ( Bader :2020:p7 ) 


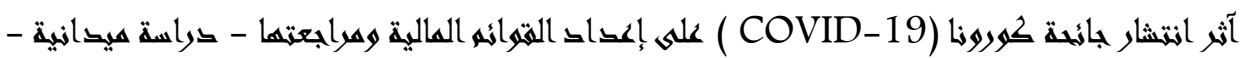
د/ وليق سمير عبد العظيه الجبلى

وفي مثل حالة التأثير ات المحتملة لظروف فيروس COVID-19 فإن على الإدارة أن

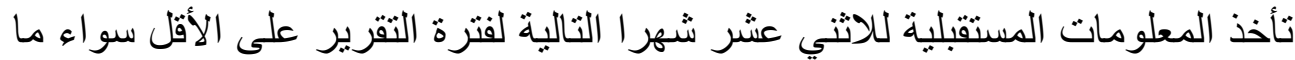

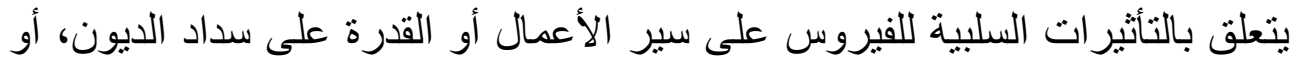
ما يتعلق بالتأثثرات الإيجابية لحزمة التسهيلات والدية الدعم التي قدمتها الدولة للألأعمال

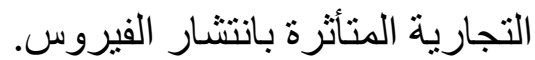
ومما ينبغي التأكيد عليه أيضاً أن على المنشأة تقييم مدى مناسبة إعداد القوائم المئم المالية على أساس الاستمرارية في ضوء الأحداث التي تقع في الفترة اللاحقة لتاريخ نهاية

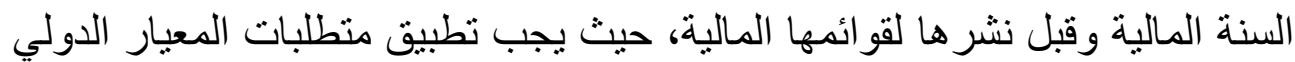

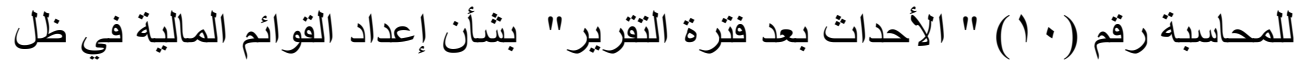

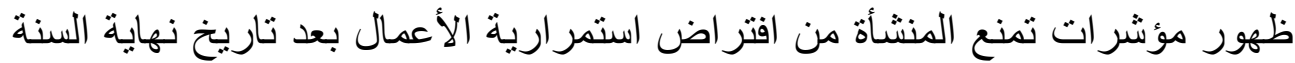
المالية وقبل نشر القوائم المالية، حيث ينص ذئ ذلك المعيار على أن تدهور النتائج

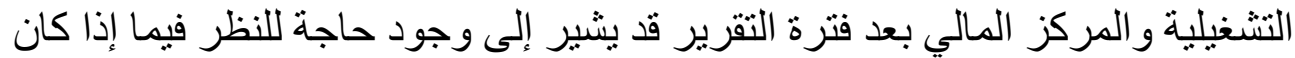

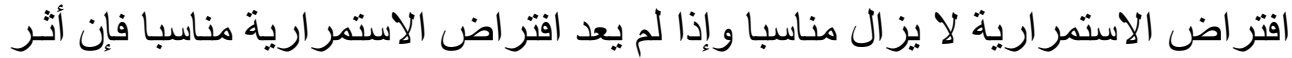

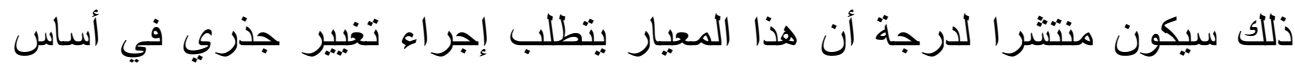
المحاسبة، وليس مجرد تعديل للمبالغ المثبتة بموجب أساس المحاسبة الأصلي. ( الهيئة

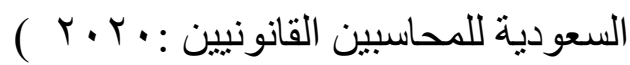
وعلى ما سبثى يرى الباحث أن :-

COVID-19 على البقاء كمنشأة مستمرة يأخذ في الحسبان كافة المعلومات الاعلى المتاحة عن المستقبل

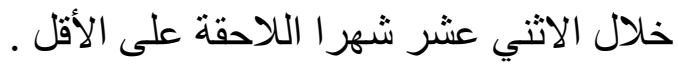

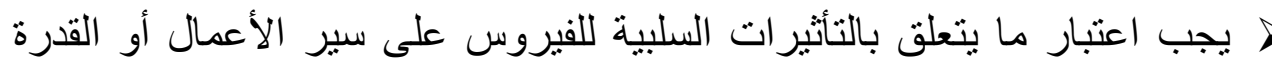

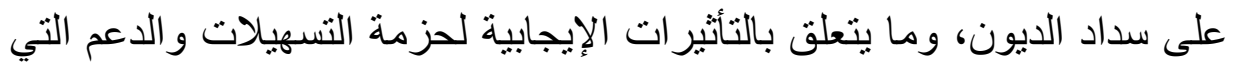

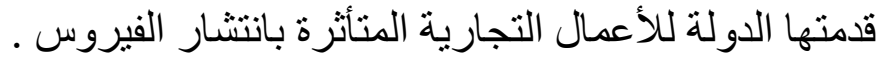

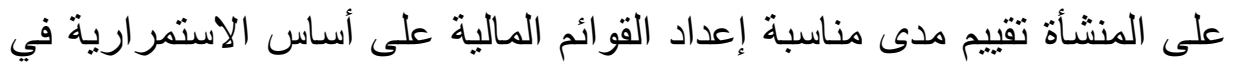
الفترة اللاحقة لتاريخ نهاية السنة المالية وقبل نشر ها لقو ائمها المالية . 


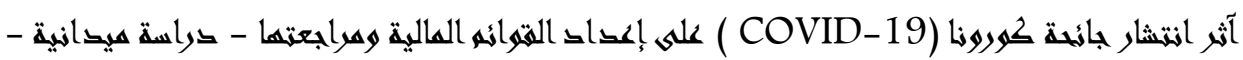
د/ وليق سمير عبد العظيه الجبلى

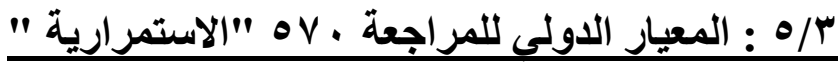

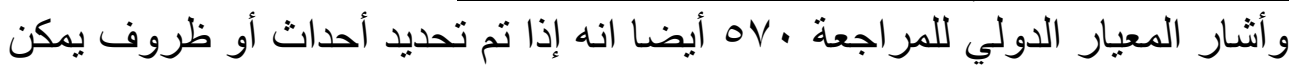

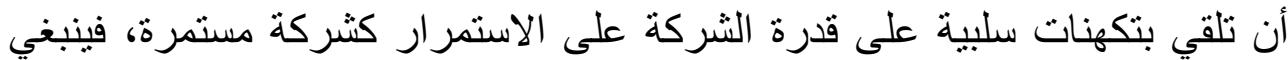

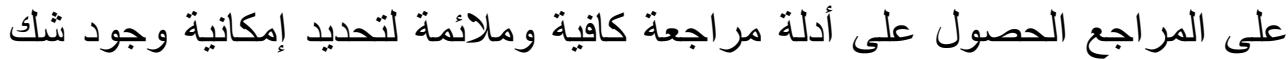

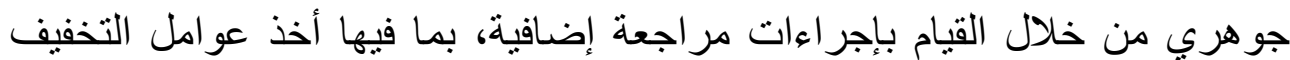

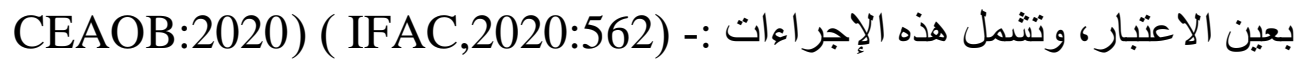

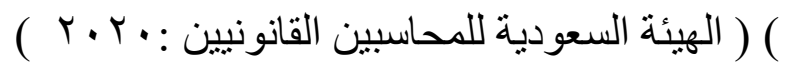
> عند عدم قيام الإدارة بتقييم قدرة الثركة على الاستمر ار كثركة مستمرة، الطلب من الإدارة عمل تقبيمها. تقييم خطط الثركة للتصرفات المستقبلية فيما يتعلق بتقييمها للشركة المستمرة، سواء كان من المرجح أن يحسن ناتج هذه الخطط من الوضع وما إذا كانت هذه الخطط > دراسة ما إذا توفرت أي معلومات أو حقائق إضافية منذ تاريخ قيام الإدارة بالتقبيم. طلب إقرار ات خطية من الإدارة، و إذا أمكن، من المكلفين بالرقابة، فيما يتعلق

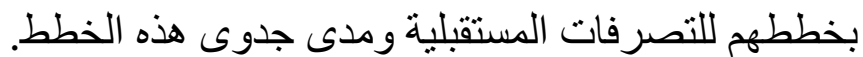

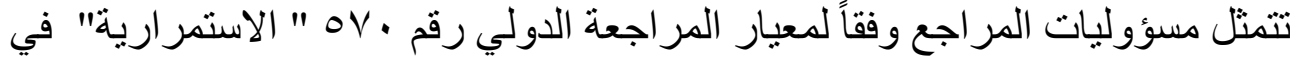

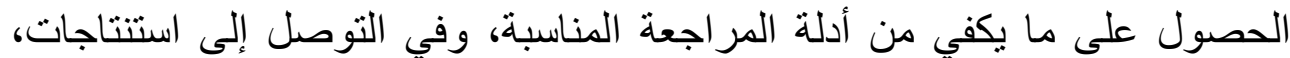
بشأن مدى مناسبة استخدام الإدارة لأساس الاستمر ارية في المحاسبة عند إعداد القوائم

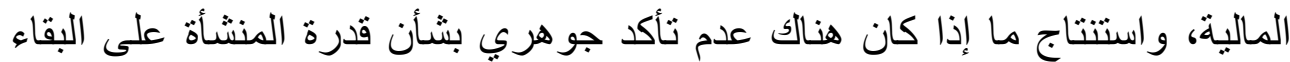

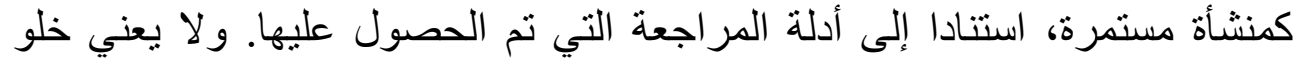

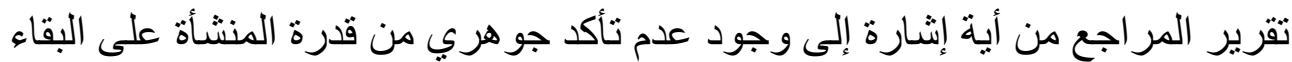

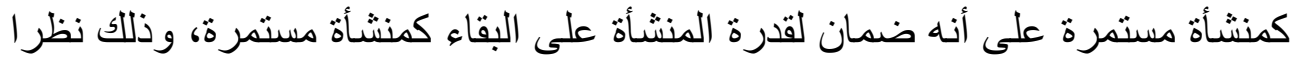

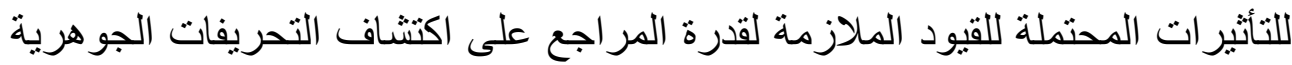
التي تزداد بالنسبة للأحداث أو الظروف المستقبلية التي قد تتسبب في توقف التف المنشأة 


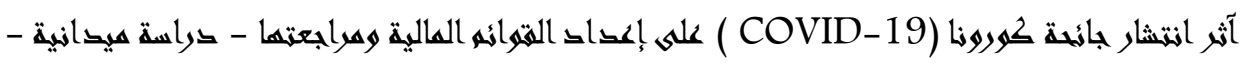
د/ وليد سمير عبد العظيه الجبملى

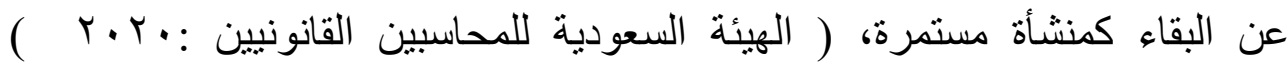
وبخاصة تللك الأحداث التي تتطور بشكل سريع وغير ممكن التنبؤ بها كما هو الحال مع آثار فيروس COVID-19 وفي ظل الظروف الحالية المتمثلة في الآثار الكبيرة

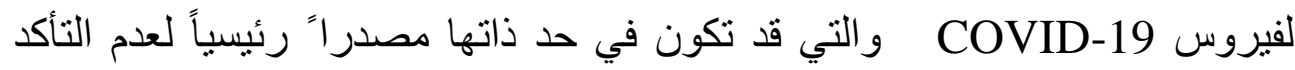
الجوهري بشأن قدرة المنشأة على البقاء كمنشأة مستمرة، فإنه تزداد في أهمية اهتمام

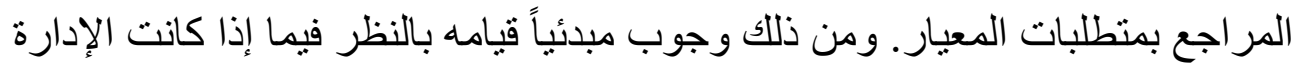

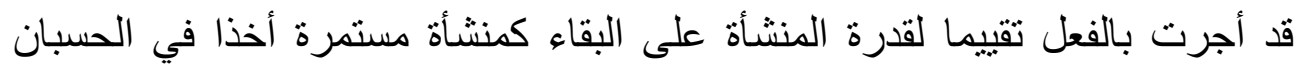

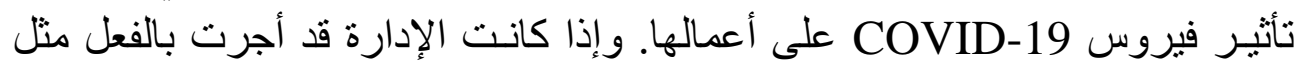

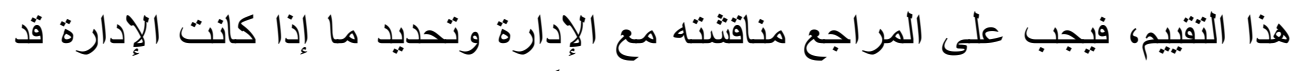
حددت أن فيروس COVID-19 قد يثير ، منفرداً أو مع أحداث أخرى، شئه شكوكا كبيرة

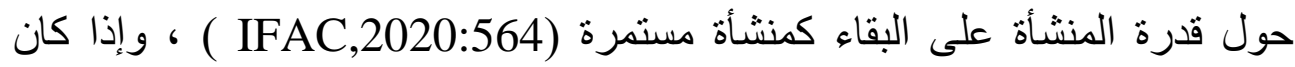

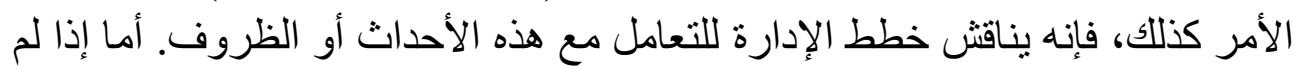

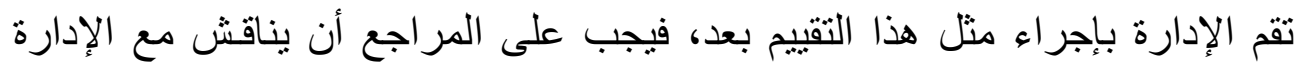

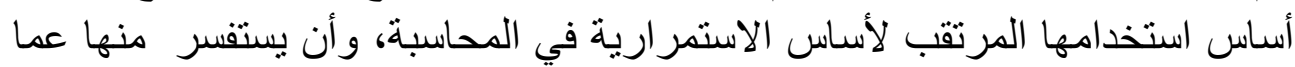

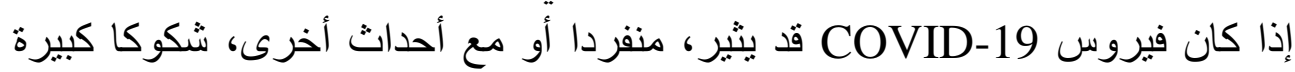
حول قدرة المنشأة على البقاء كمنشأة مستمرة.

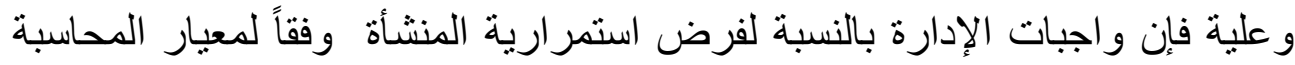

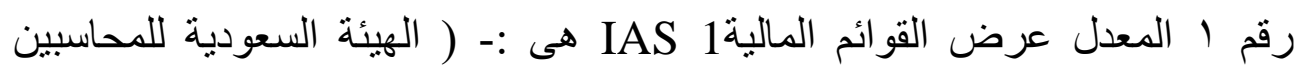

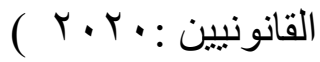
ا. يجب على الإدارة عند إعداد القوائم المالية تقييم مدى قدرة المنشأة على القى الاستمرار Y. يجب إعداد القوائم المالية على أساس افتر اض استمرارية المنشأة فى حالة عدم

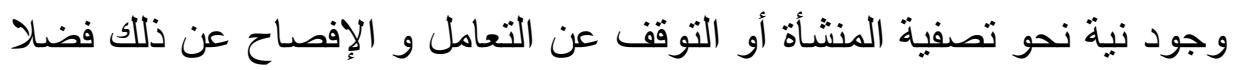
عن الإفصاح عن الأساس المطبق في إعداد القو ائم المالية . 


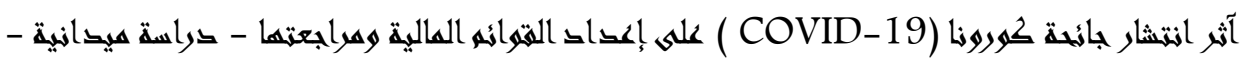
د/ وليد سهير عبد العظيه الجبلمى

r. إذا كان لدى الإدارة ـ عند تقيمها لقدرة المنشأة على الاستمرار ـ علم بوجود حالة

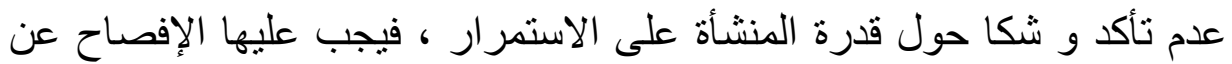

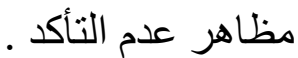

ع. يجب على الإدارة عند عدم إعداد القوائم المالية طبقا لفرض الاستمرارية الإفصاح عن ذلك و سبب اعتبار المنشأة غير مستمرة .

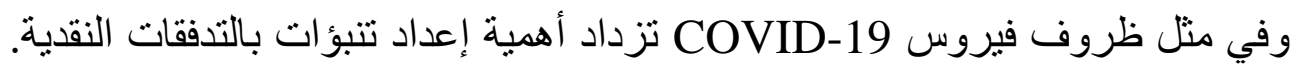

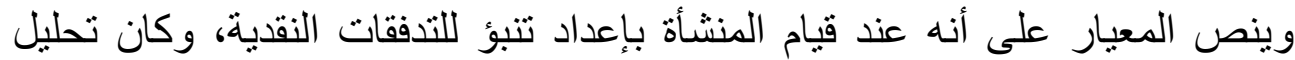

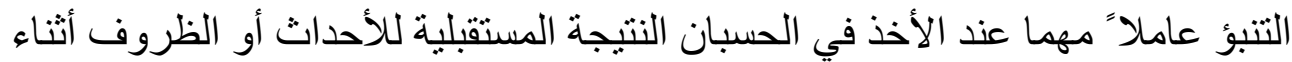

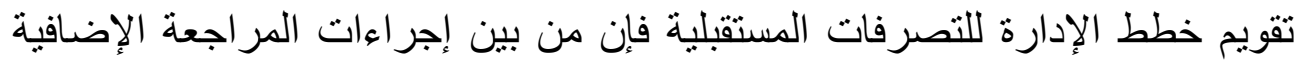

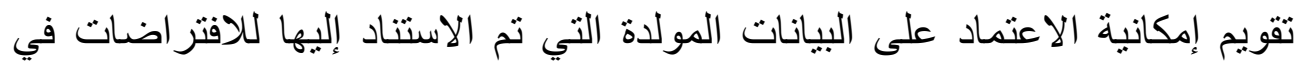

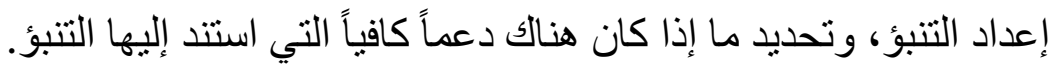

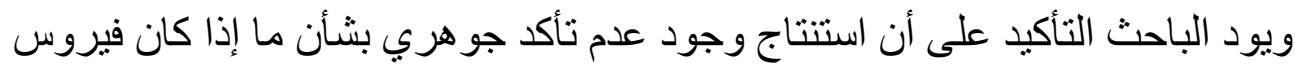
COVID-19

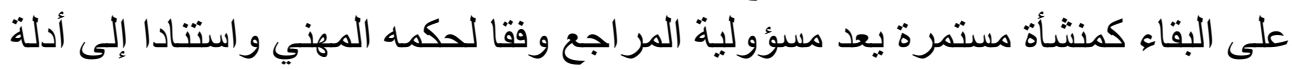

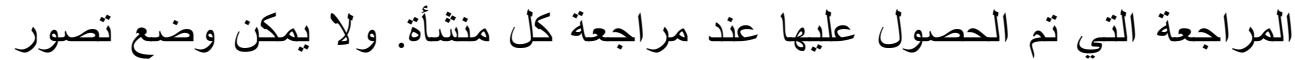

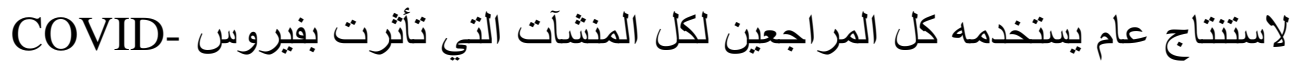

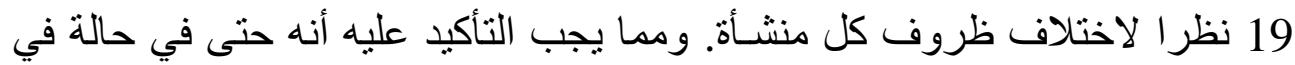

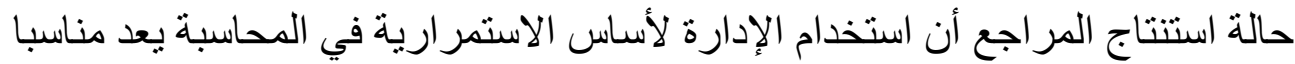

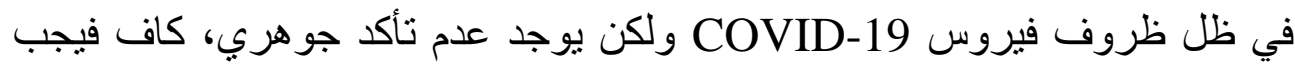

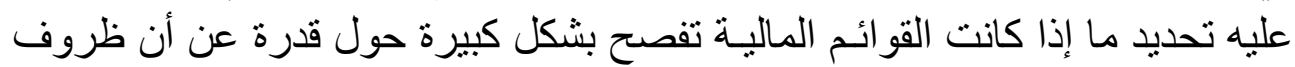

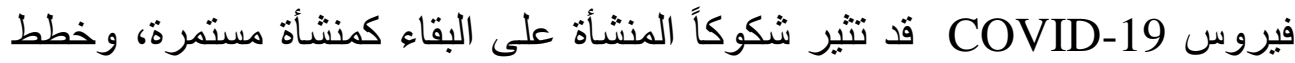

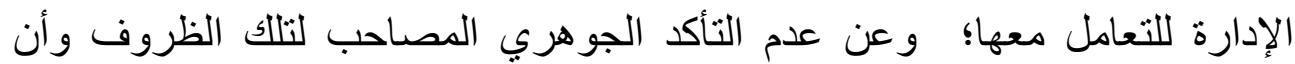
المنشأة بناء على ذللك، قد تكون غير قادرة على تحقيق أصولها و الوفاء بالتز اماتها

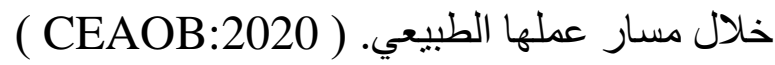




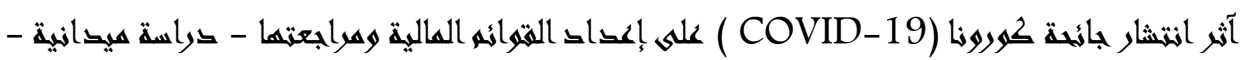
د/ وليد سهير عبد العظيه الجبلمى

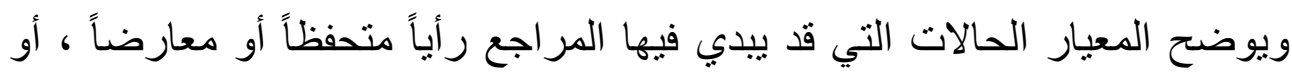

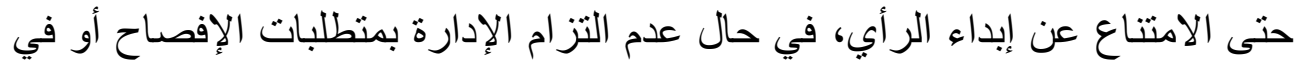

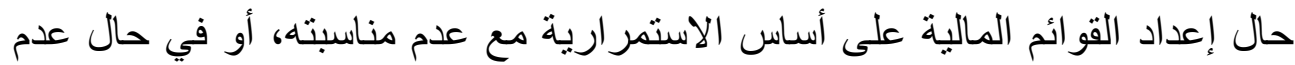

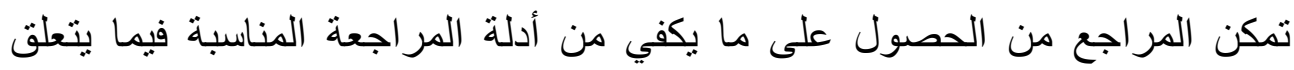

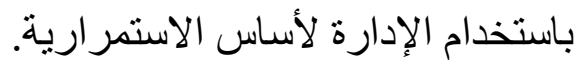

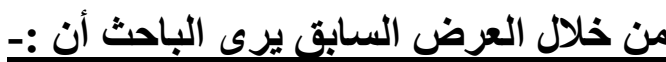

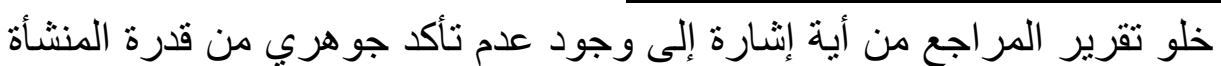

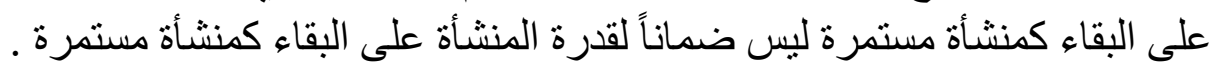
لا يجب على المر اجع أن يناقش مع الإدارة خططها للتعامل مع فيروس- COVID

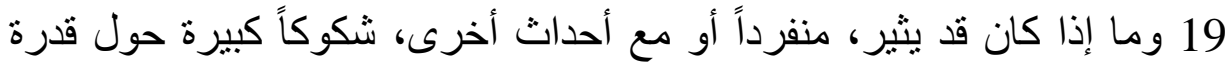

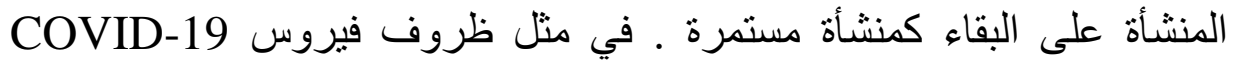
تزداد أهمية إعداد تتبؤات بالتدفقات النقدية .

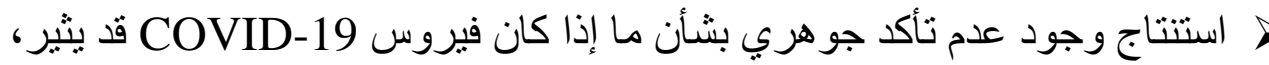

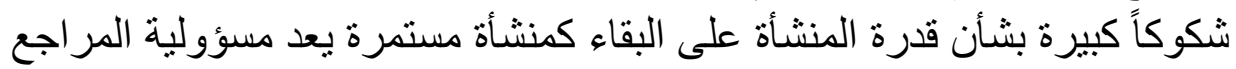

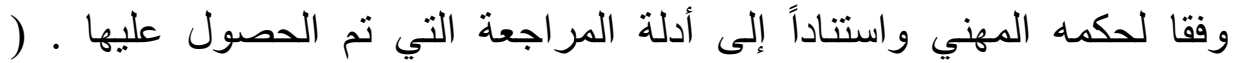

( ASIC:2020

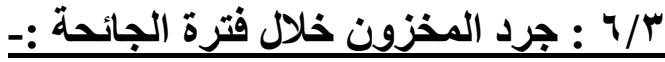

يتم قياس المخزون وفق المعيار المحاسبي الدولي القيمة القابلة للتحقق NRV أيهما أقل. وفي ظل بيئة اقتصادية غير مستقرة، قد يكون

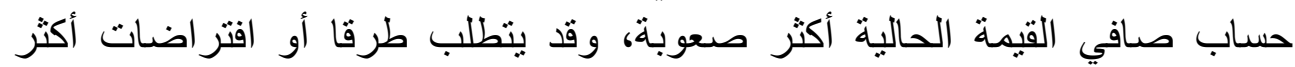
تفصيلا. وعند تحقق الخسائر نتيجة لانخفاض قيمة المخزون، فئن إن هذه الخسائر

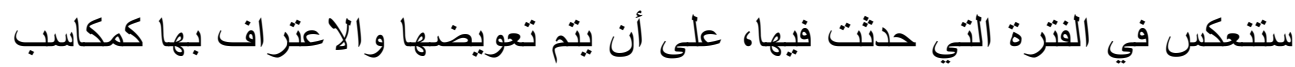
في الفترات اللاحقة عند عودة ارتفاع قيمته مرة أخرى.

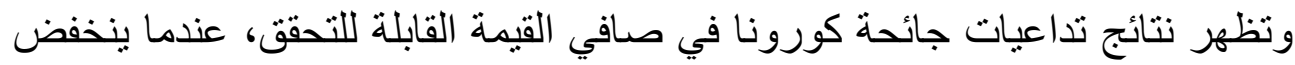
الطلب على بعض المنتجات، وهو ما قد يؤدي إلى الضغط على فئ أسعار المبيعات، أو 


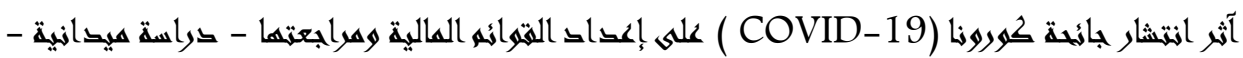
د/ وليخ سمير عبط العظيه الجبلى

قد يؤدي إلى انخفاض في معدل دوران المخزون، ليترتب على ذلك حدوث تخفيضات

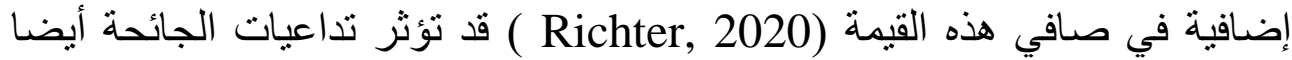
على قابلية استرداد أرصدة المخزون، إذ قد تضطر بعض الثركات التي لديها قو ائم

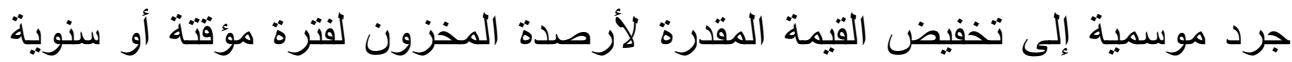
نتيجة لضعف أو انخفاض مستويات المبيعات المتوقعة، كما قد تضطر الثرة الثركات الصناعية إلى إعادة تقييم ممارساتها الخاصة بمعدلات تحميل التكاليف العامة الثابتة نتيجة للانخفاض المتوقع في حجم الإنتاج بشكل غير طبيعي خلال العام نتيجة لإغلاق

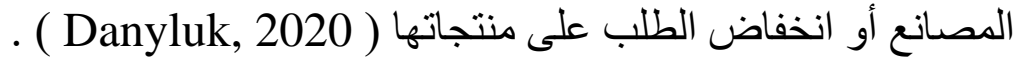

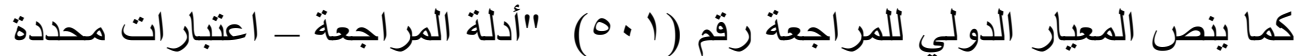

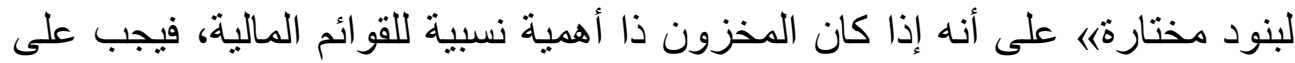
المراجع الحصول على ما يكفي من أدلة المراجعة المناسبة فيما يتعلق بوجود المدانه

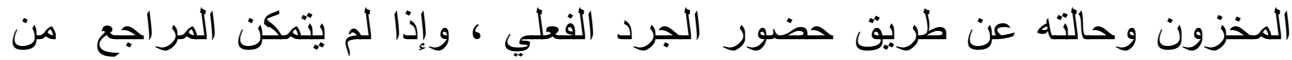

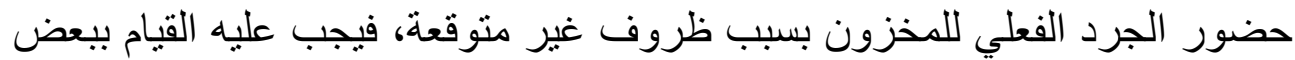

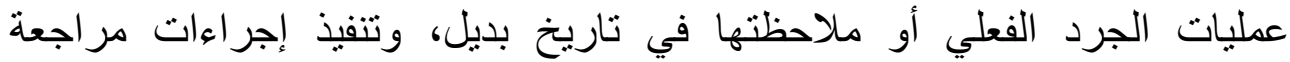
للمعاملات التي تمت في الفترة الفاصلة. ( المجمع العربى للمحاسبين القانونيين

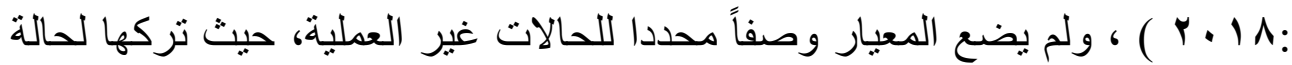

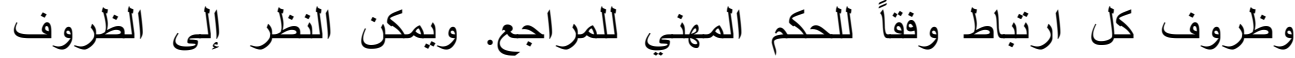

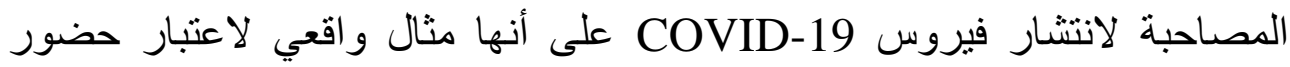

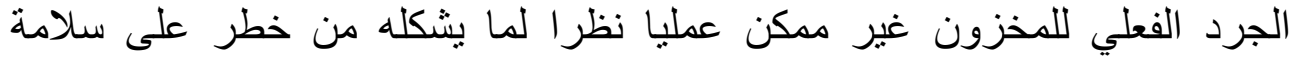

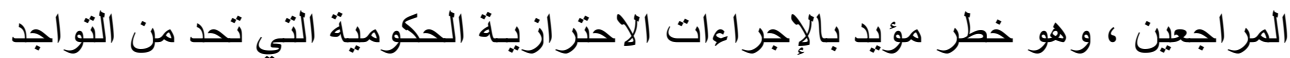

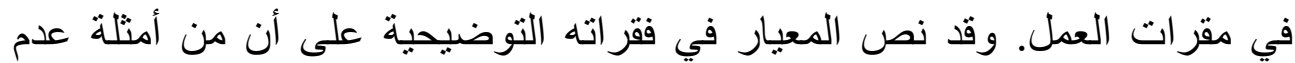

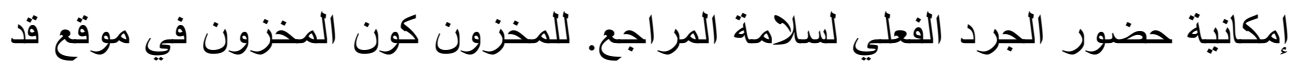

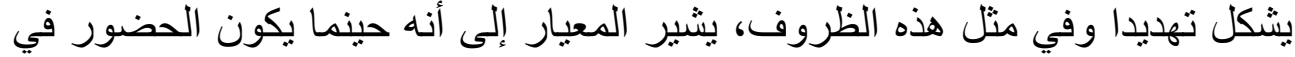

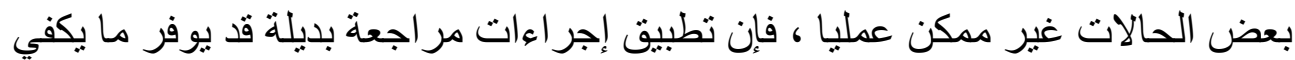
من أدلة المر اجعة المناسبة بشأن وجود المخزون وحالتها، على فلى سبيل المثال، التقصي 


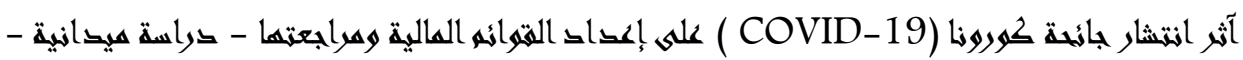
د/ وليد سهير عبد العظيه الجبلمى

عن مستندات البيع الذي تم لاحقا لبنود مخزون محددة تم الحصول عليها أو شر اؤها

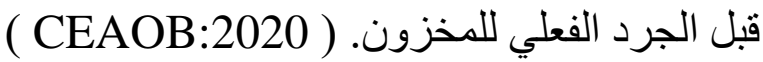
وقد يكون من المناسب ما أمكن إثر الك المر اجع الداخلي في عملية الجرد عن بعد من خلال

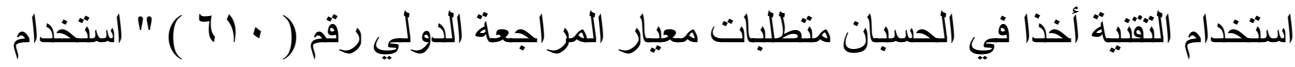

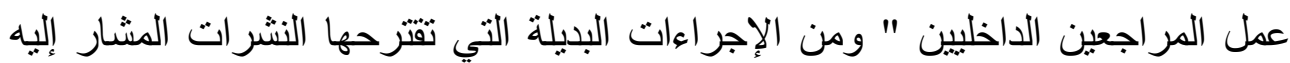

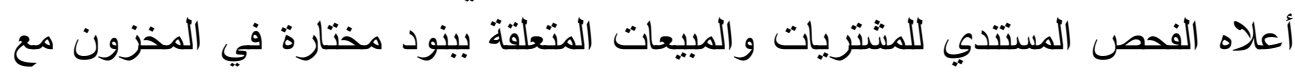

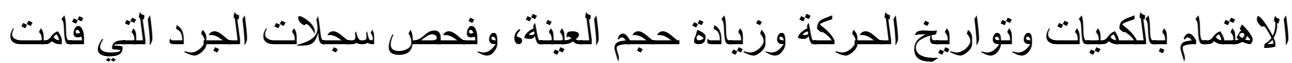

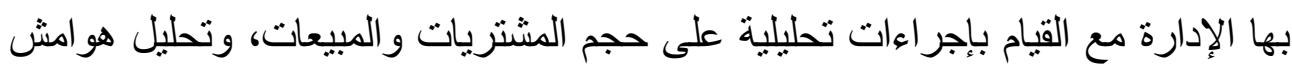

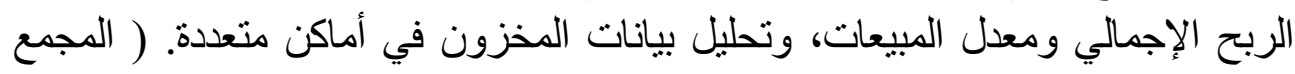

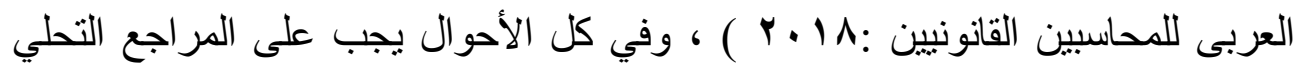

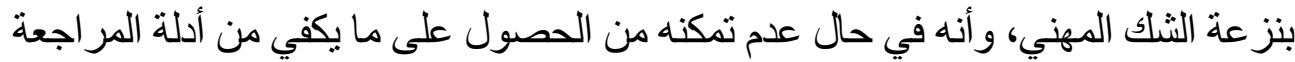

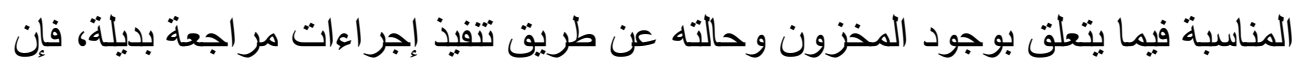

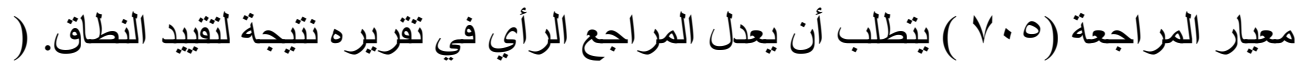

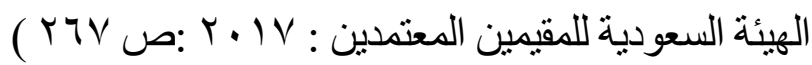

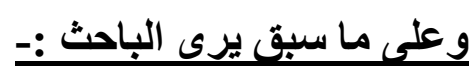

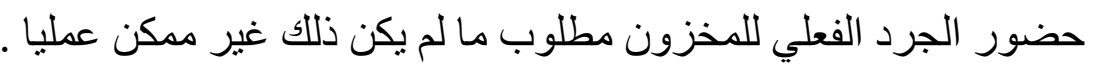

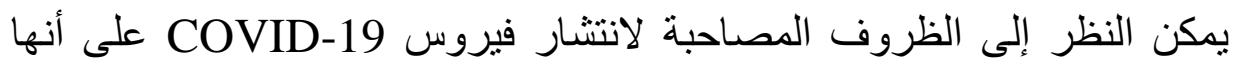

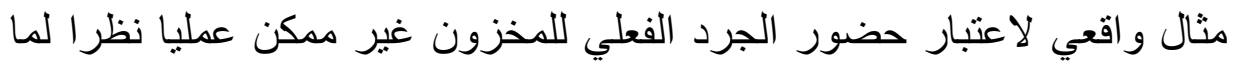

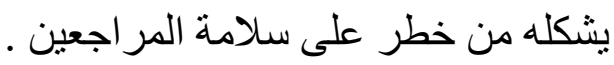

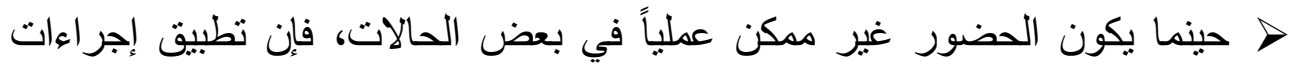

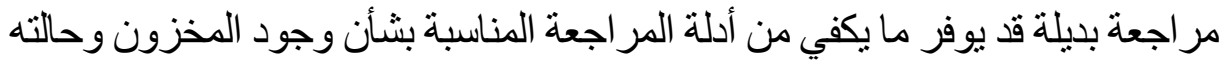

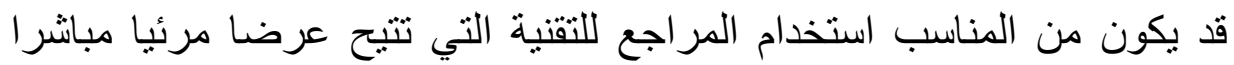

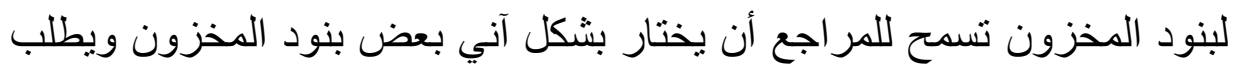

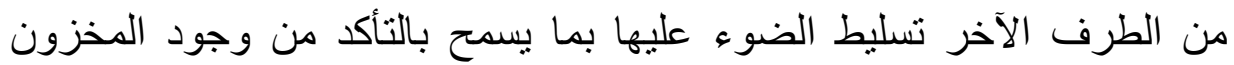

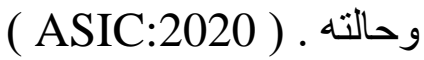




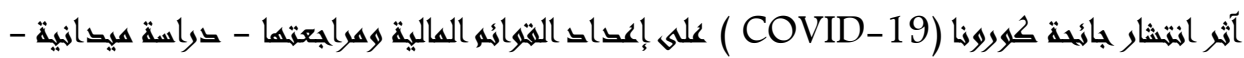
د/ وليق سمير عبد العظيه الجبلى

> ويجدر تذكير المراجعين بأهمية الثك المهني في إطار أداء مسؤولياتهم المهنية في

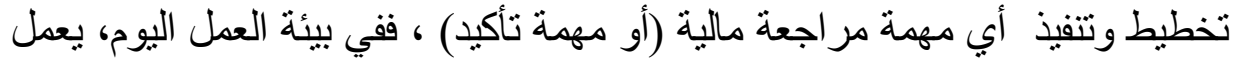

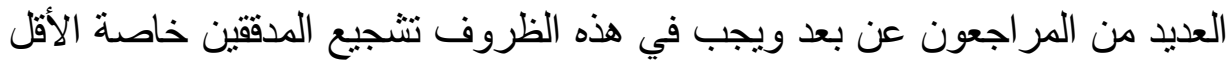

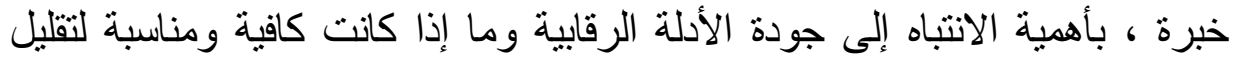

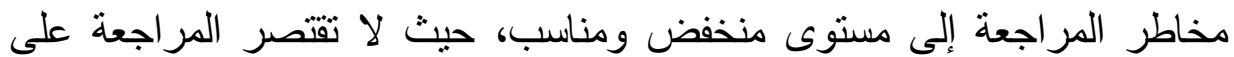

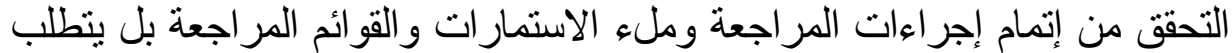

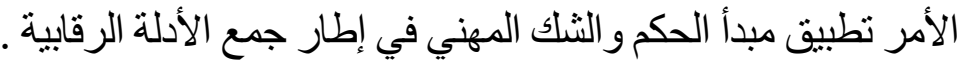

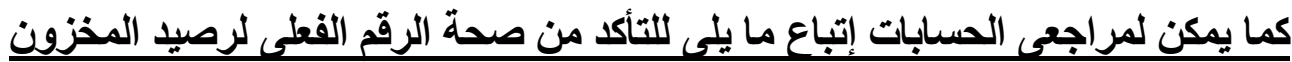
( ICAEW:2020 ) ( CEAOB:2020) ( AASB\&AUASB:2020)

( ASIC:2020)

1- عمليات الجرد المادية :- إذا كان المخزون المادي عنصرا جوهريا بالنسبة للبيانات

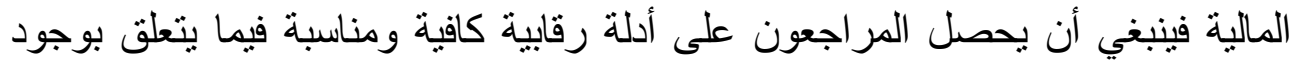
المخزون وحالته، حيث تتمثل الأهداف العامة للمراجع المستقل وفقا لمعايير المراجعة

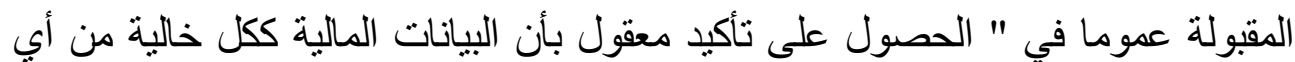

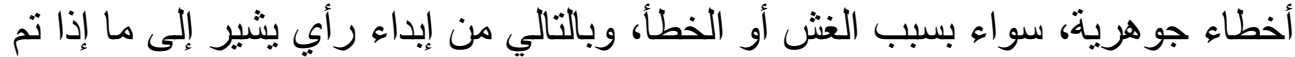

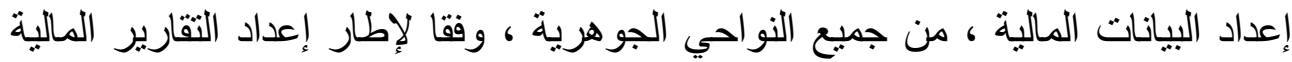
المعدول به ، وفي خضم جائحة COVID-19 قد يو اجه المر اجعون حالات تكون فيها

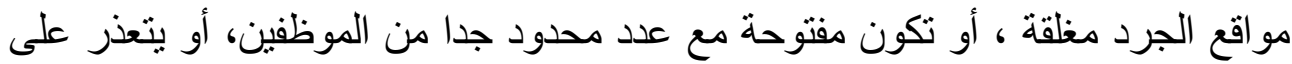

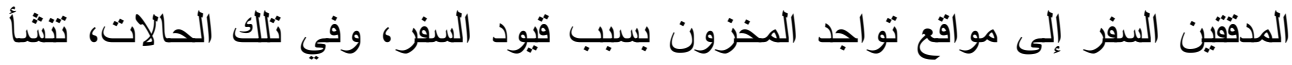

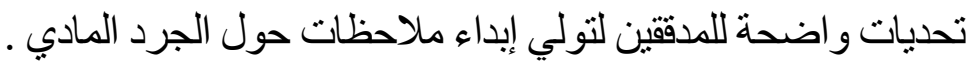

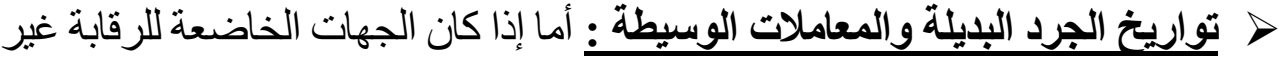

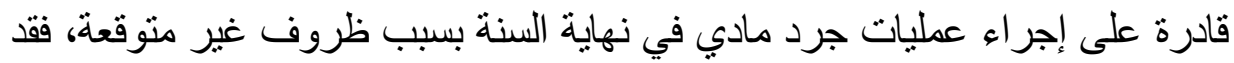

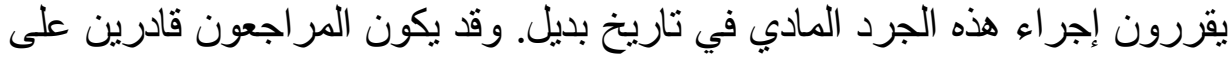
مر اقبة عمليات الجرد المعاد جدولتها وتتفيذ إجر اءات مر اجعة إضافية على العلى العمليات الوسيطة التي تمت بين تاريخ نهاية السنة وتاريخ قيام الجهة الخاضعة للرقابة إنهابة بعملية 


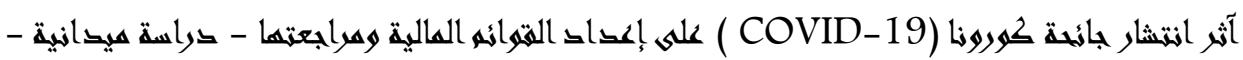
د/ وليد سهير عبد العظيه الجبلمى

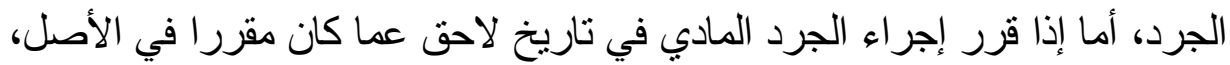

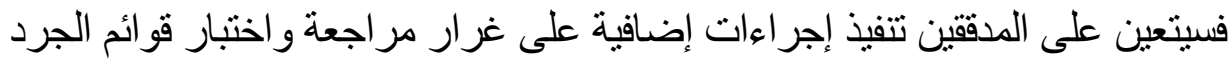

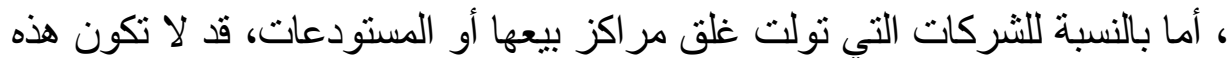
مهمة صعبة لأنه سيكون هنالك عدد قليل من المعاملات التي تم القيام بها بين نهاية السنة

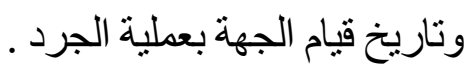

اذا كان المراجع غير قادر على حضور الجرد :- في بعض الحالات ، قد تكون الجهات

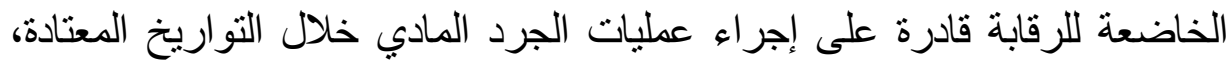

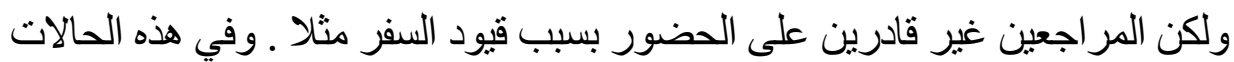

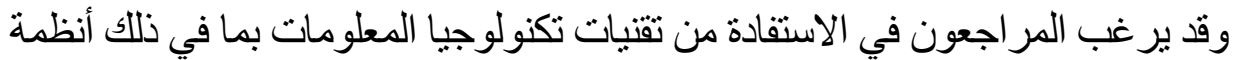

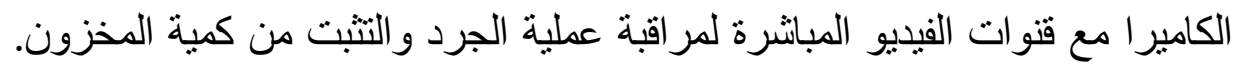
ولكن، يجب أن يدرك المراجعون أن الإجراءات التي يمكن تتفيذها فعليا قد تكون

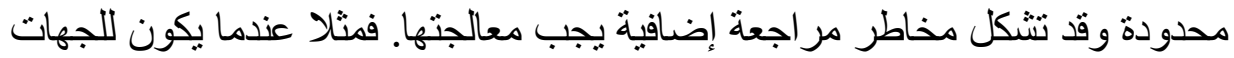

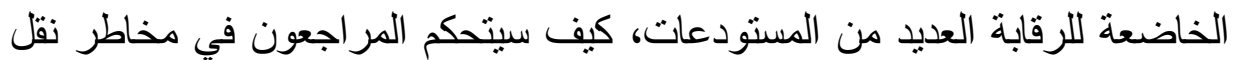

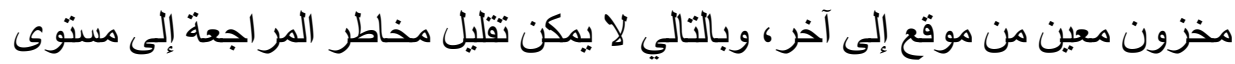

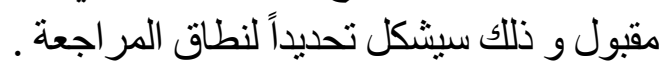

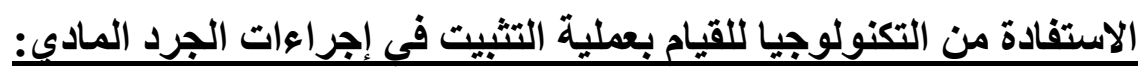

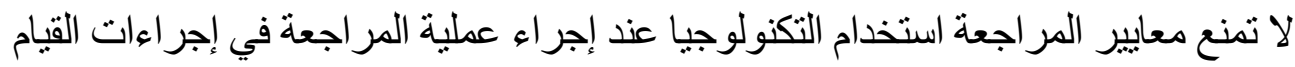
بالجرد المادي للمخزون، فقد يكون المراجعون قادرون على استخدام التقنيات الحديثة

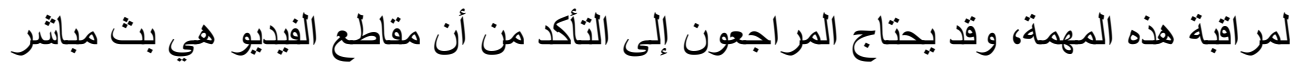

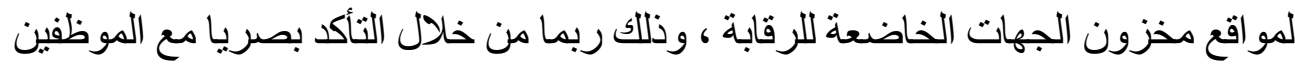
الرئيسيين واستخدام تكنولوجيا الصوت والتمكن من نقل الكاميرات إلى مواقع محددة

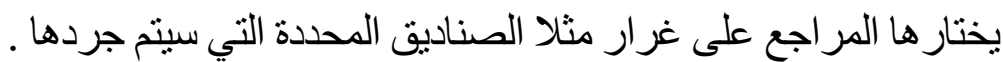

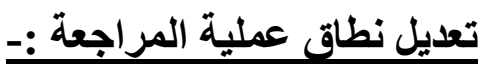

في الحالات التي تكون فيها الجهات الخاضعة للرقابة التهابة غير قادرة على إجراء جرد مادي

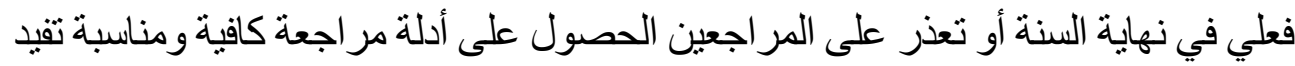




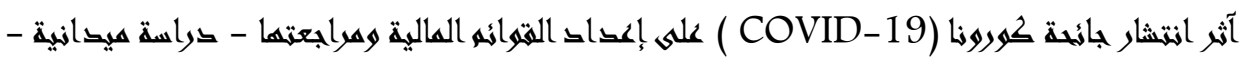
د/ وليخ سمير عبط العظيه الجبلى

بأن عمليات الجرد نم إجراؤها بشكل صحيح (سواء كان المراجع غير قادر على حضور عمليات الجرد المادي شخصياً أو عن بعد ، أو غير قادر على التأكد من قيمة المخزون في تاريخ نهاية السنة الموافق لتاريخ ختم الميزانية وذلك من خلال إعادة الإحتساب و القيام بإجراءات مر اجعة إضنافية حول العمليات التي تمث خلال الفترة من تاريخ إنتهاء السنة المو افق لتاريخ الميز انية إلى غاية تاريخ الجرد الفعلي للمخزون) فمن المرجح أن تمثل هذه الإشكاليات تحدياً لنطاق المر اجعة يمكن أن تؤدي إلى تعديل تقرير المر اجع .

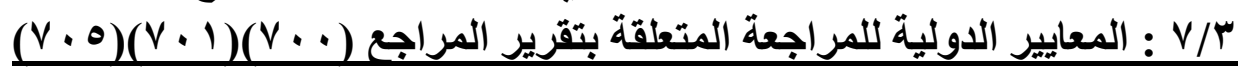
$(V \cdot 7)$

في ظل ظروف فيروس COVID-19 من المتوقع أن بعطي مستخدمو التقارير المالية من الثقة على معلومات القوائم المالية. وينص المعيار الدولي للمر اجعة رقم

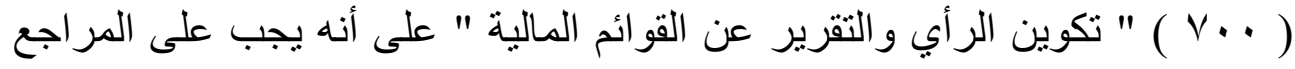
تقويم ما إذا كانت القوائم الماليةُمعدة، من جميع الجوانب الجوهرية، وفقا لمتطلبات إطار التقرير المالي المنطبق. ويجب أن يتضمن هذا التقويم النظر في الجوانب النوعية للممارسات المحاسبية الخاصة بالمنشأة، بما في ذلك المؤشرات على وجود تحيز محتمل في اجتهادات الإدارة. وبشكل خاص، وفي ضوء متطلبات إطار التقرير المالي المنطبق، يتطلب من المراجع، من بين عدة أمور، تقويم ما إذا كانت القوائم المالية تفصح بشكل مناسب عن السياسات المحاسبية المهمة المختارة و المطبقة. أخذا في الحسبان مدى ملائمتها ومناسبتها للمنشأة، و عرضها بطريقة قابلة للفهم؛ و اتساقها مع إطار التقرير المالي المنطبق، وما إذا كانت التقدير ات المحاسبية التي أجرتها الإدارة تعد معقولة. كما بطلب المعيار من المراجع تقويم ما إذا كانت القو ائم المالية توفر إفصاحات كافية لتمكين المستخدمين المستهدفين من فهم تأثير المعاملات و الأحداث المهمة على المعلومات الواردة في القوائم المالية. (IFAC,2020:612 ) ومن المسائل التي قد يرى المراجع الاهتمام بها في مثل الوضع الراهن، النظر في تضمين التقرير تأثير ظروف فيروس COVID-19 ضمن الأمور الرئيسة للمر اجعة وفقاً للمعيار الدولي للمر اجعة رقم ( ( . V)" الإبلاغ عن الأمور الرئيسة للمر اجعة في 


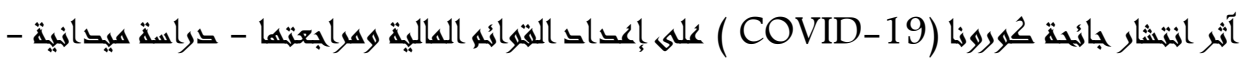
د/ وليق سمير عبد العظيه الجبلى

تقرير المراجع المستقل" ويعرف ذللك المعيار الأمور الرئيسة للمراجعة بأنها تلك

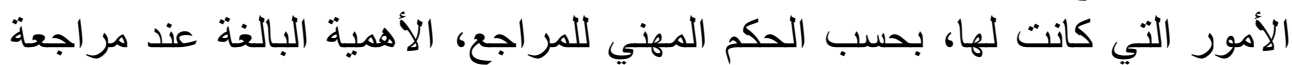

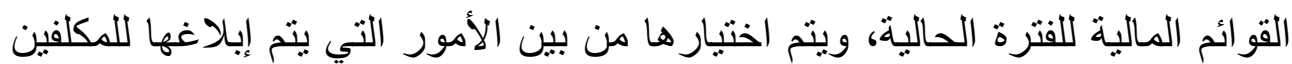

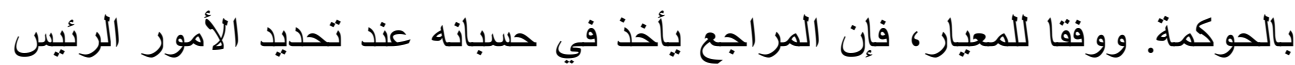

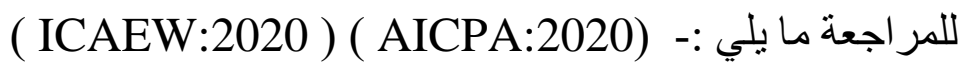
ا. المجالات التي يرتفع فيها خطر التحريف الجوهري المقيم أو المخاطر المهمة المحددة. r. أحكام المراجع المهمة فيما يتعلق بالمجالات الواردة في القوائم المالية، والتي

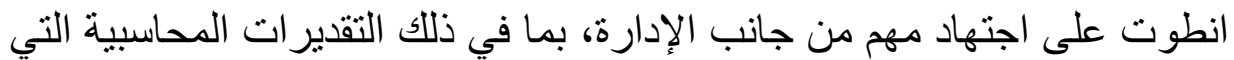
تم تحديد أنها تحتوي على عدم تأكد مرتفع في التقدير.

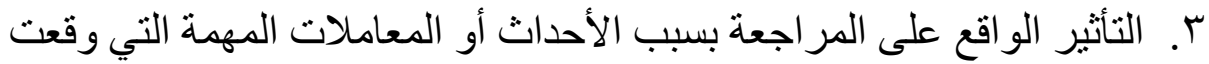

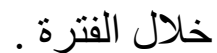

ويجب على المر اجع أن يحدد من بين الأمور المحددة وفقاً للاعتبار ات المشار إلبها أعلاه تلك الأمور التي كانت لها الأهمية البالغة عند مر اجعة القور ائم المالية للفترة

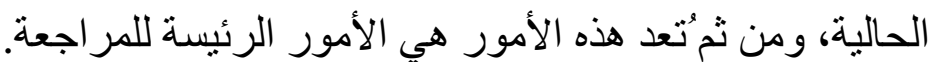

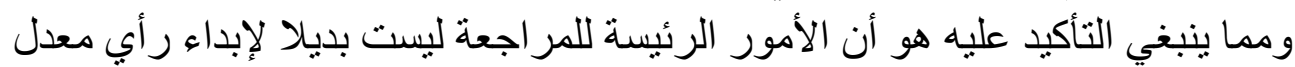

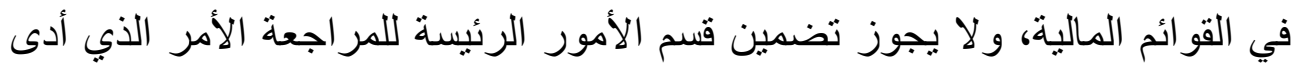

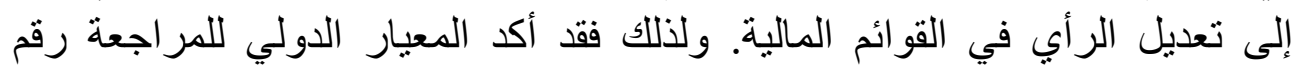

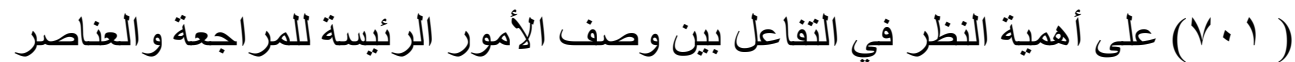

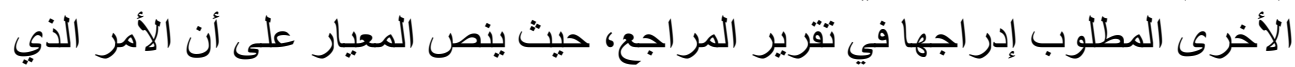

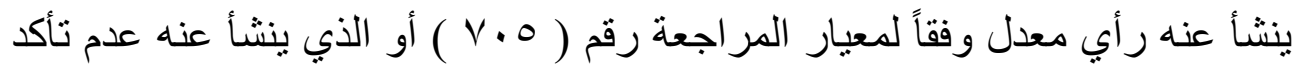

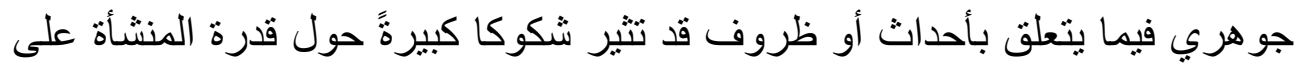

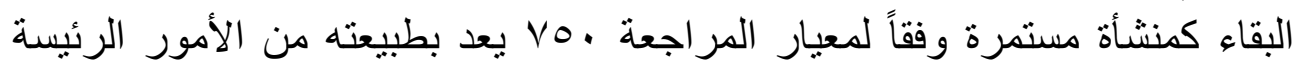

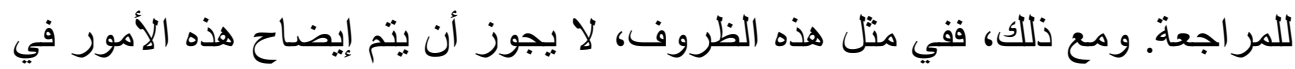




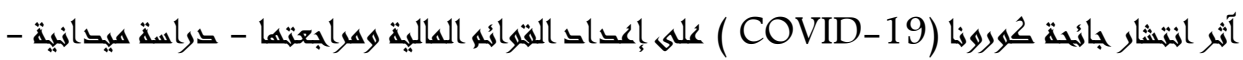
د/ وليخ سمير عمب العظيه الجبلمى

قسم الأمور الرئيسة للمر اجعة في تقرير المراجع، وبدلاً من ذلك يجب على المراجع

( Kieso et al 2020:p245 ) -: $\checkmark$

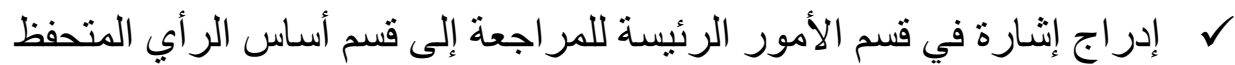

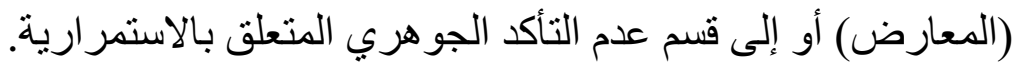

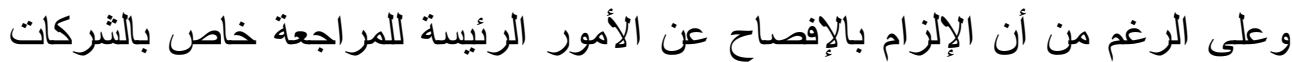

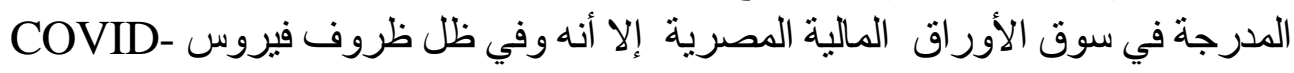
19 ، قد يرى المراجع مناسبة الإفصاح عن آثار هذه الظروف الأ على مراجعة القوفي فائم المالية لشركة غير مدرجة إذا رأى أن ذلك من بين الأمور التي كانت لها، بحسب التهب حكمه المهني،

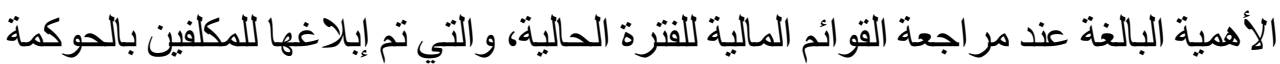
و إذا لم تكن ظروف فيروس COVID-19 من بين الأمور المبلغ عنها على أنها من

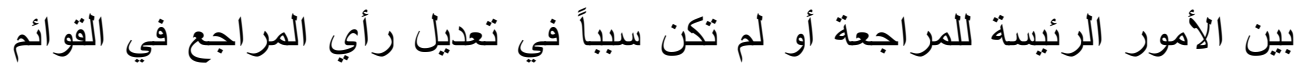

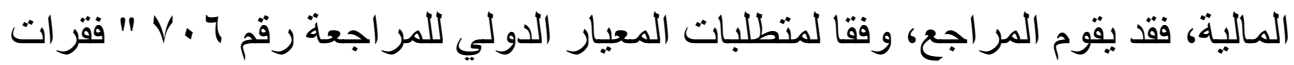

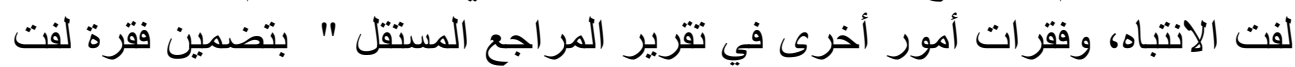

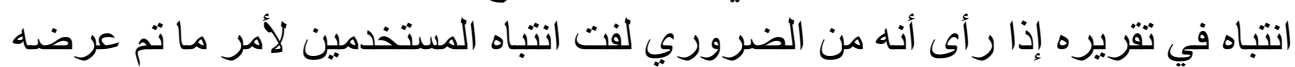

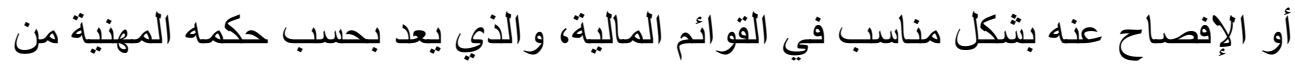

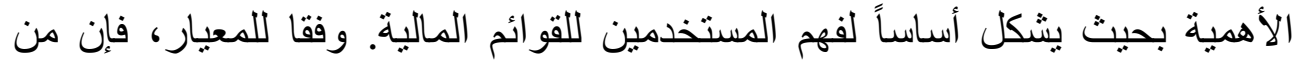

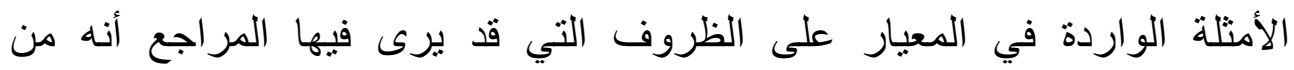

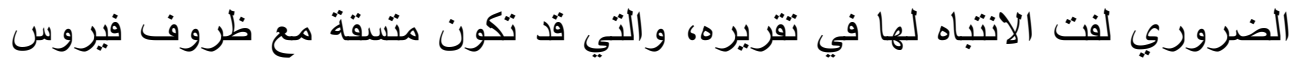

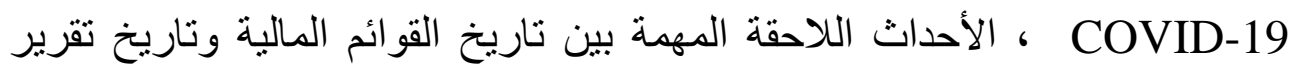
المراجع،. ووقوع كارثة كبيرة أثرت أو لا تز ال تؤثر بشكل مهر على المركز المالي للمنشأة .

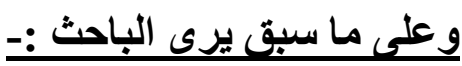

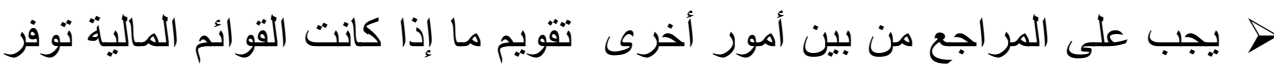

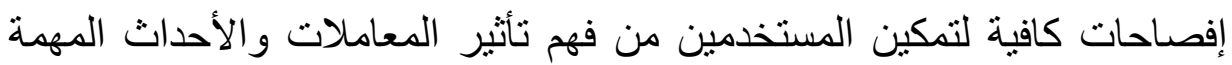




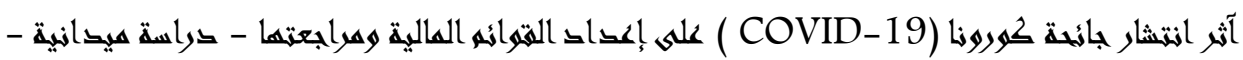
د/ وليخ سمير عبط العظيه الجبلى

$$
\text { على المعلومات الو اردة في القو ائم المالية . }
$$

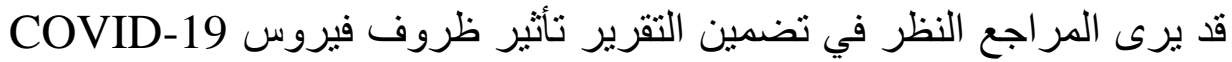

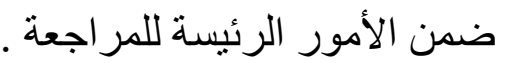

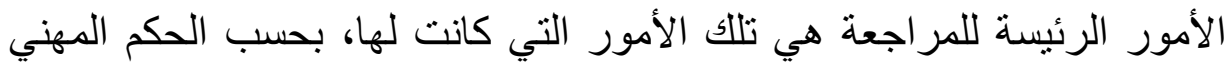

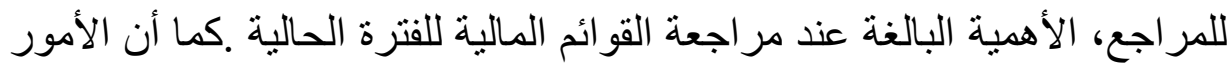
الرئيسة للمر اجعة ليست بديلا لإبداء رأي معدل في القو ائم المالية .

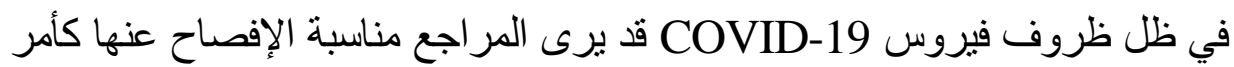

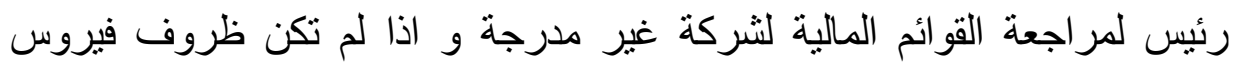

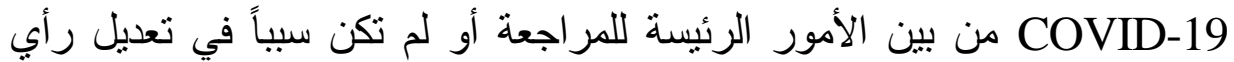

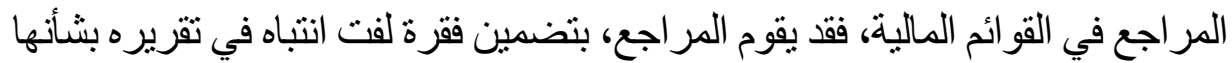

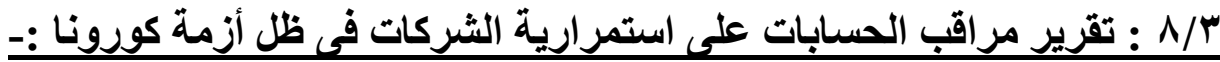

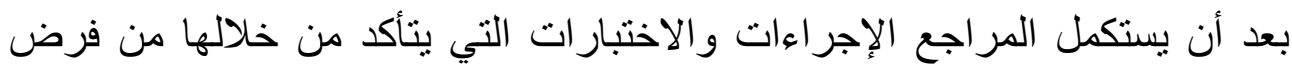

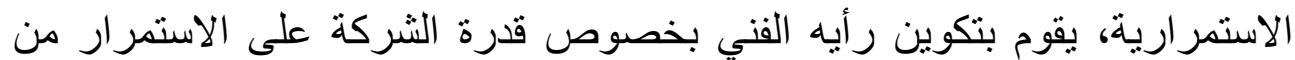

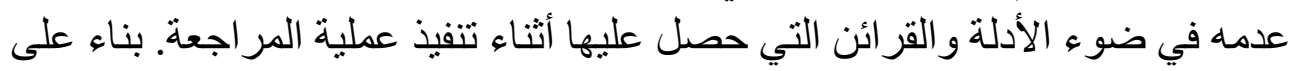

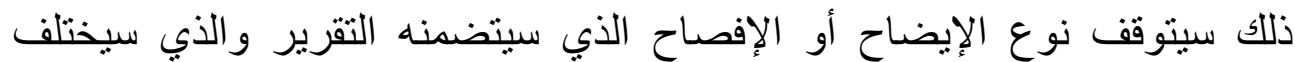

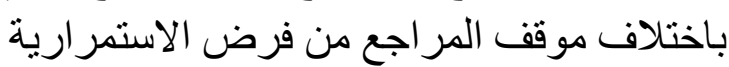
ومن الجدير بالذكر إن تقرير المراجع يساعد في ترسيخ مصداقية القو ائم المالية، ومع الإع

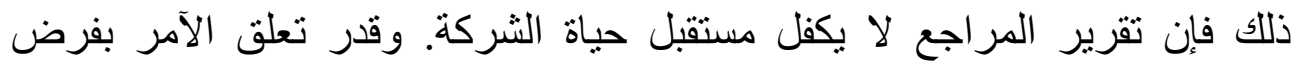

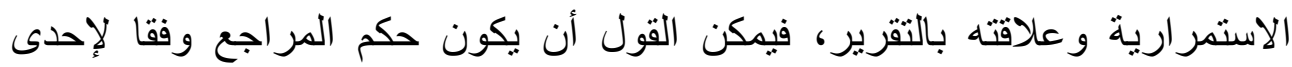
الحالات الآتية: ( ICAEW:2020 )

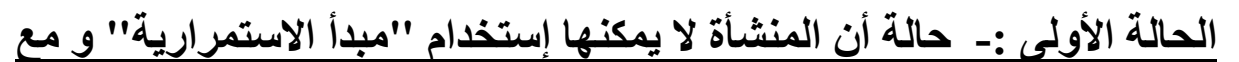

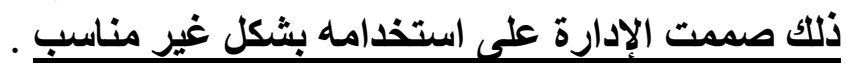
يجب على المراجع عمل تقرير عكسي لان مبدأ الاستمر ارية هو أساس استخدام

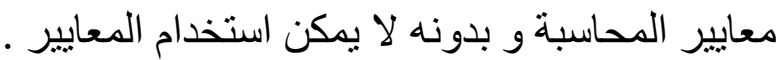




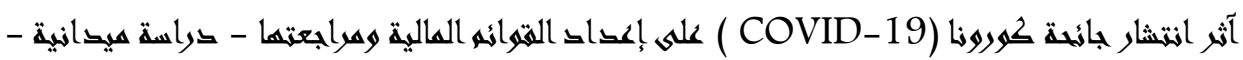
د/ وليق سمير عبد العظيه الجبلى

الحالة الثانية :- حالات إن المنشأة تستخدم مبدأ الاستمر ارية مناسب و لكن

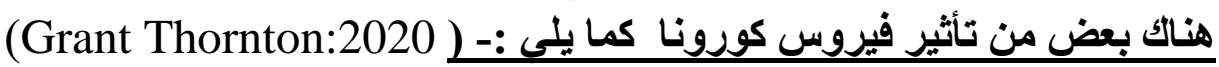

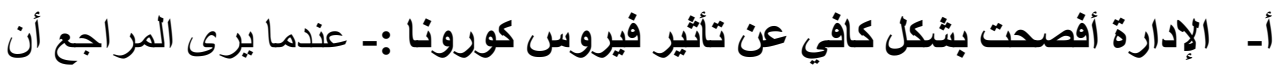

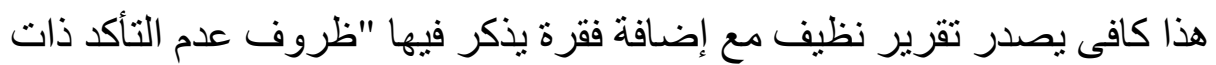

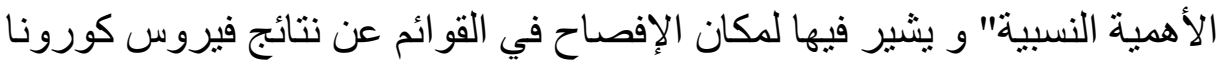
و تأثيره على حجم الأعمال . الأنئ. بـ الإدارة لم تفصح بشكل كافي عن تأثير فيروس كورونـا :- عندما يرى المر اجع أن ذلك ألك

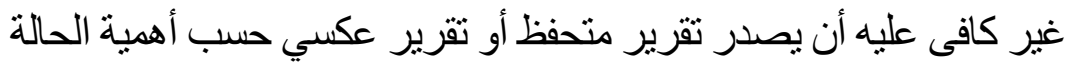

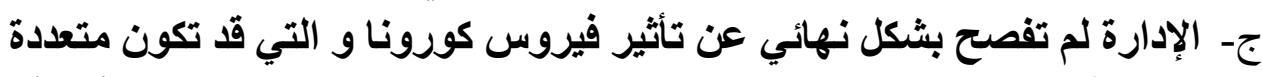

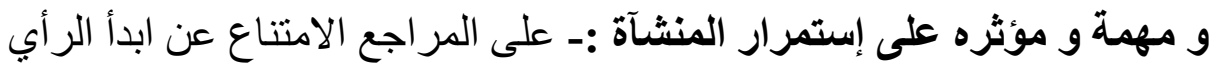

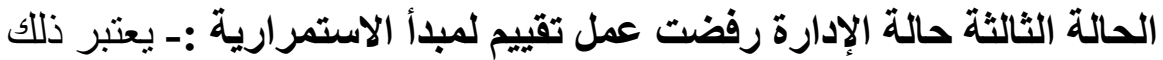

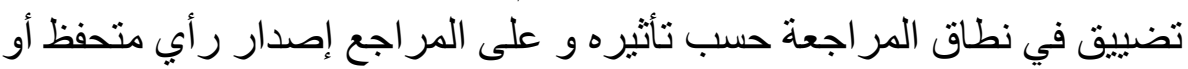

$$
\text { يمتنع عن ابدأ الرأي }
$$

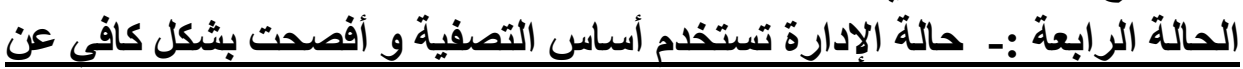

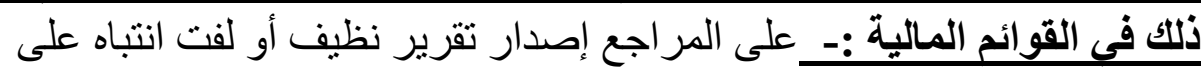

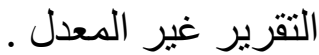

\section{المحور الرابع : الاراسة الميدانية}

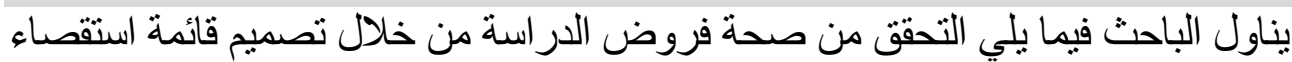

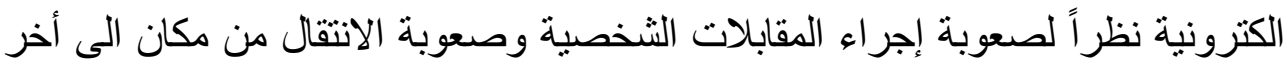
خلال تلك الفترة التى تمر بها البلاد والإجراءات الاحترازية الناتجة من انتشار جائحة

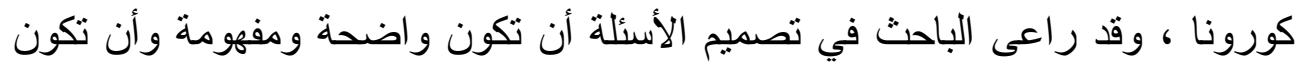

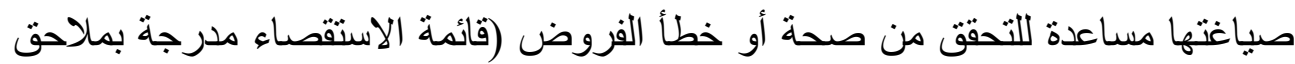

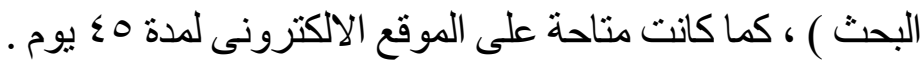

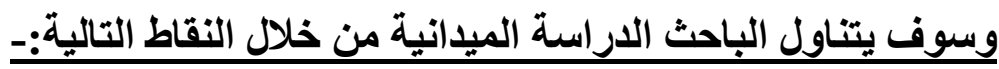

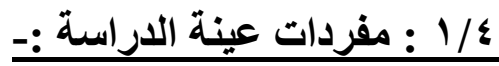




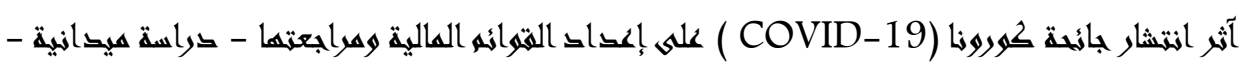
د/ وليق سمير عبد العظيه الجبملى

تتكون عينة الدر اسة من ( الأكاديميين تخصص محاسبة ومر اجعة ، علوم حاسب ، نظم المعلومات ، الإحصاء التطبيقى ) ، ( محللى النظم فى كافة التخصصات ) ، (مراقبى حسابات الثركات المساهمة ) ، ( المراجعين الداخليين فى الثركات المساهمة ) ،

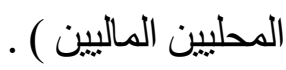

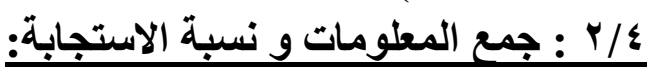

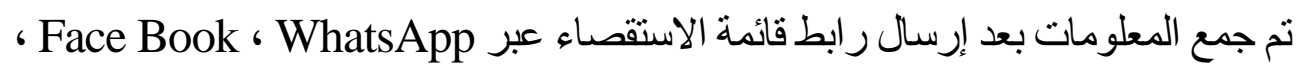
Messenger ، G Mail

\begin{tabular}{|c|c|c|c|c|}
\hline \multicolumn{2}{|c|}{ القوائم الصحيحة } & \multirow[b]{2}{*}{ القوائم المرفوضة } & \multirow[b]{2}{*}{ القوائم المستلمة } & \multirow[b]{2}{*}{ القئات } \\
\hline نسبة\%\% & عدد & & & \\
\hline$\wedge \wedge .7$ & $r q$ & 0 & $\varepsilon \varepsilon$ & الأكاديميين \\
\hline $79 . r$ & 9 & $\varepsilon$ & 14 & محللى النظم \\
\hline$\wedge 7 .\{$ & 19 & $r$ & rr & مراقبى الحسابات \\
\hline. $\mathrm{VO}$ & 9 & $r$ & Ir & المراجعين الداخليين \\
\hline $1 \cdot .9$ & IV & $\varepsilon$ & $r$ & المحليين الماليين \\
\hline$\Lambda r . \cdot r$ & 94 & 19 & $11 r$ & الاجمالى \\
\hline
\end{tabular}

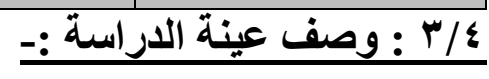

يعرض الدول التالى وصف عينة الدر اسة وفقاً لكلا من ( الوظيفة - سنو ات الخبرة -

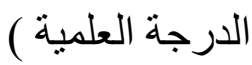

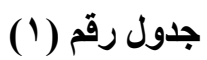

\begin{tabular}{|c|c|c|c|}
\hline النسبة \% & 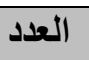 & البيان & \multirow{7}{*}{ الوظيفة } \\
\hline$\$ 1.9$ & $r q$ & الأكاديميين & \\
\hline 9.8 & 9 & محللى النظم & \\
\hline$r \cdot . \varepsilon$ & 19 & مراقبى الحسابات & \\
\hline 9.8 & 9 & المراجعين الداخليين & \\
\hline $1 \wedge . r$ & IV & المحليين الماليين & \\
\hline $1 \ldots$ & 94 & الاجمالى & \\
\hline$\varepsilon 0 . Y$ & $\varepsilon r$ & أقل من • سنوات & \\
\hline
\end{tabular}

$14 \cdot 9$

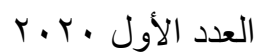




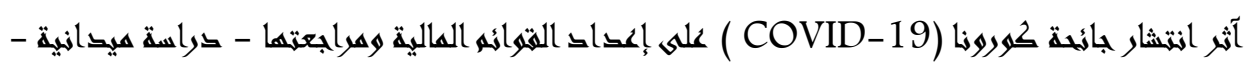
د/ وليق سمير عبد العظيه الجبلمى

\begin{tabular}{|c|c|c|c|}
\hline$\varepsilon r$ & $\varepsilon$. & من • : · 1 سنوات & \multirow[t]{3}{*}{ سنوات الخبرة } \\
\hline 11.1 & 11 & • ا سنوات فأكثر & \\
\hline $1 \cdots$ & 94 & الاجمالى & \\
\hline Y I. & $r$. & بكالوريوس & \multirow{5}{*}{ الدرجة العلمية } \\
\hline 19.8 & 11 & دراسـات عليا & \\
\hline YI.0 & $r \cdot$ & ماجستير & \\
\hline rV. & ro & دكتوراه & \\
\hline $1 \cdots$ & 94 & الاجمالى & \\
\hline
\end{tabular}

- : ع : : حساب ثبات المقباس

يتم حساب ثبات المقياس بطريفة ألفا كرونباخ كما بالجدول رقم (Y) التالى :-

\begin{tabular}{|c|c|c|}
\hline معامل ألفا كرونباخ & \multicolumn{2}{|l|}{ محاور الدراسة } \\
\hline$\because \vee \wedge 9$ & والاقتص يهى المالى لمنشآث الأعمال . تأثير تفشى جائحة كورونا على النشاط & 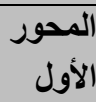 \\
\hline$\because \vee \wedge I$ & 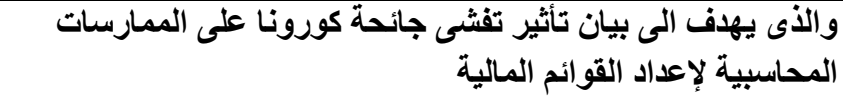 & الثانى المحور \\
\hline 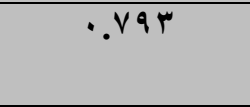 & والمهنية لمراجف الى بيان تأثير تفشى جائحة كورونا على الممارسات & الثالث \\
\hline$\because V \wedge V$ & \multicolumn{2}{|l|}{ الارجة الكلية للثبات } \\
\hline
\end{tabular}

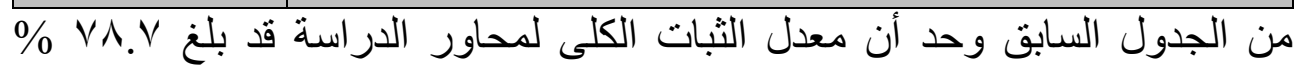

$$
\text { وبذلك بعتبر المقياس ثابت الى حد كبير . }
$$

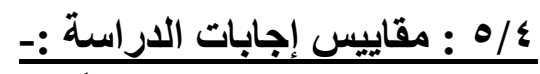

تم استخدام الميز ان التقديرى وفقاً لمقياس ليكرت الخماسى ، كما فى الجدول رقم (ب) التالى

\begin{tabular}{|c|c|c|}
\hline الاتجاه العام & المتوسط المرجح & الاستجابة \\
\hline عدم الموافقة بشدة & $1.1 \cdot: 1$ & لا أوافق بشدة \\
\hline عدم الموافقة & Y.Y.: I.^I & لا أوافق \\
\hline محايدة & r.\&.: Y. TI & محايد \\
\hline المو افقة & $\varepsilon . Y \cdot: Y . \leqslant 1$ & أوافق \\
\hline الموافقة بشدة & أكثر من Y. . & أوافق بشدة \\
\hline
\end{tabular}




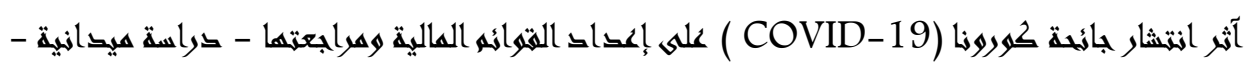
د/ وليق سمير عبد العظيه الجبملى

\section{ك/}

و لاختبار الفرض الرئيسي للار اسة و ما ينبثق عنه من فروض فر عية تم تصميم قائمة استقصاء تضمنت ثلاثة محاور وهى :-

المحور الأول يعبر عن الفرض الأول والذى يهدف الى بيان تأثثر تفشى جائحة كورونا على النشاط الاقتصادى و المالى لمنشآت الأعمال . المحور الثانى يعبر عن الفرض الثانى والذى يهدف الى بيان تأثير تفشى جائحة

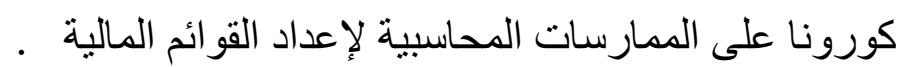
المحور الثالث بعبر عن الفرض الثالث و الذى يهدف الى بيان تأثبر تفثى جائحة كورونا على الممارسات المهنية لمر اجعة القو ائم المالية

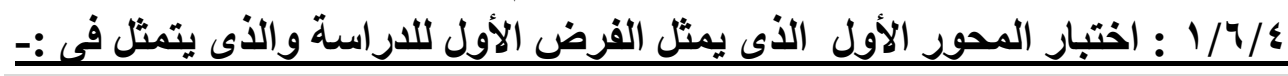
" لا توجد علاقة ذات دلالة إحصائية بين تأثير تفشى جائحة كورونا و التشاط

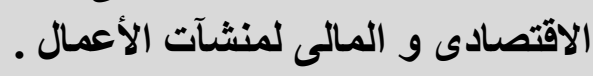

\begin{tabular}{|c|c|c|c|c|c|c|c|c|}
\hline \multicolumn{9}{|c|}{ جدول رقم (ع ) اختبار المحور الأول } \\
\hline التطيق & المرجح & لا أوافتى & 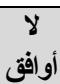 & محايد & أوافث & بثدة & 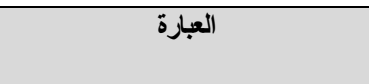 & 5 \\
\hline بشدة & $\varepsilon . \varepsilon$ & 1 & $r$ & $\mathrm{~V}$ & rq & or & 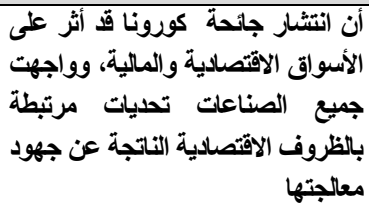 & $T$ \\
\hline بشدة & \&.r & $\bar{r}$ & $r$ & $\bar{v}$ & $r$. & 01 & 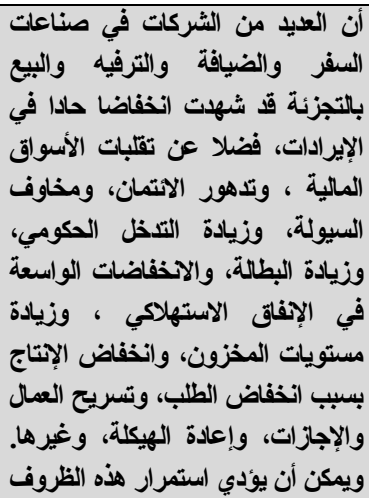 & $r$ \\
\hline
\end{tabular}




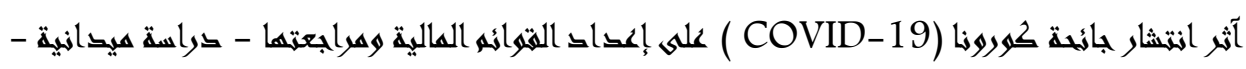
د/ وليق سمير عبد العظيه الجبلمى

\begin{tabular}{|c|c|c|c|c|c|c|c|c|}
\hline & & & & & & & 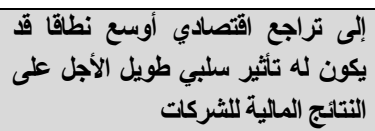 & \\
\hline بشدة & \&.r & . & $\varepsilon$ & 1. & ro & \& $\varepsilon$ & 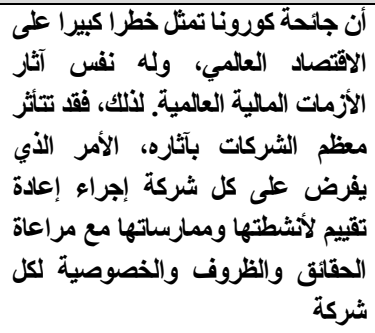 & $r$ \\
\hline بشدة & $\varepsilon . \Gamma$ & 1 & $\varepsilon$ & $V$ & $r q$ & $\leqslant 0$ & 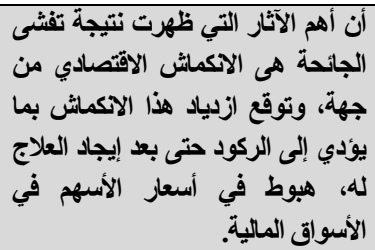 & $\varepsilon$ \\
\hline بشدة & \&.r & $\cdot$ & $r$ & 1. & $r V$ & $\varepsilon r$ & 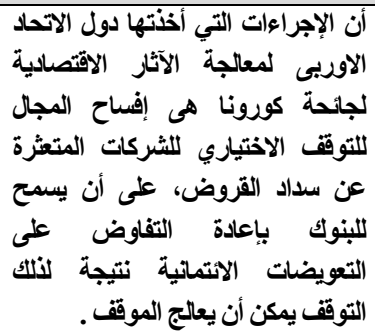 & 0 \\
\hline أوافق & \&.r & $r$ & $r$ & 9 & $r \wedge$ & 01 & 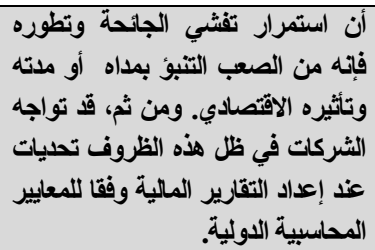 & 7 \\
\hline بشدة & $\varepsilon . r$ & \multicolumn{7}{|c|}{ التقييم العام } \\
\hline
\end{tabular}

المصدر : إعداد الباحث من مخرجات برنامج SPSS

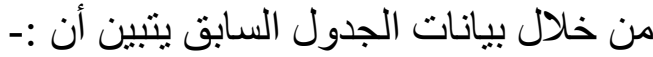
> >تيجة تحليل المحور الأول المتعلق بفرض الدراسة الأول المتعلق بتأثثر تفشى جائحة كورونا على النشاط الاقتصادى و المالى لمنشآت الأعمال تمثلت في (7) 


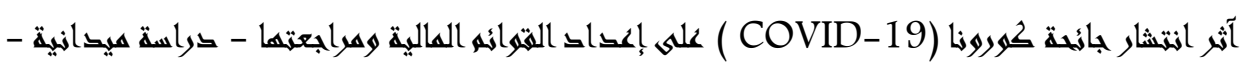
د/ وليق سمير عبد العظيه الجبملى

عبار ات أوافق بشدة ، أما متوسط إجابات المحور ككل بلغ ( ب.ء ) وهذا

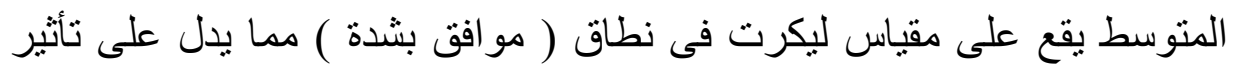

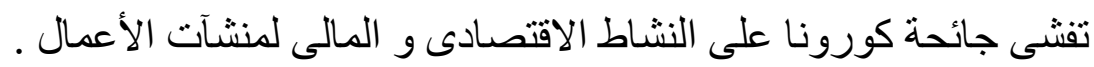

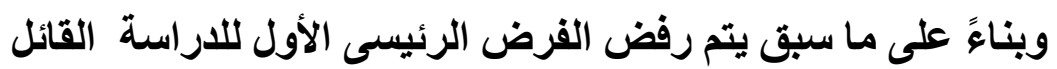

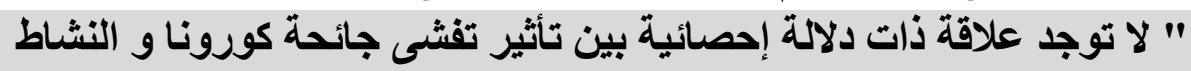

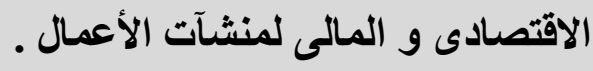

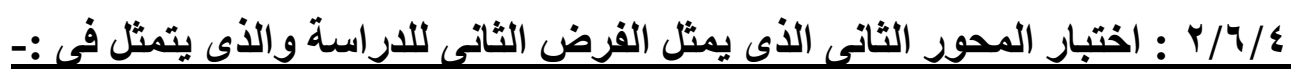

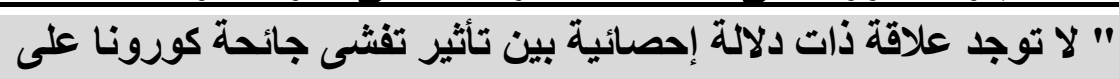

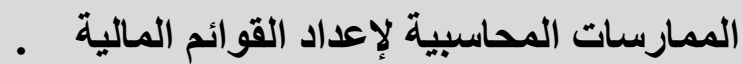

\begin{tabular}{|c|c|c|c|c|c|c|c|c|}
\hline التعليق & المرجع & لا لأوة & لا أوافق & محايد & أوافق & بشدة أوافق & العبارة & p \\
\hline أوافق بثدة & ะ. $\vee$ & . & . & Y & $Y \Lambda$ & $T Y$ & 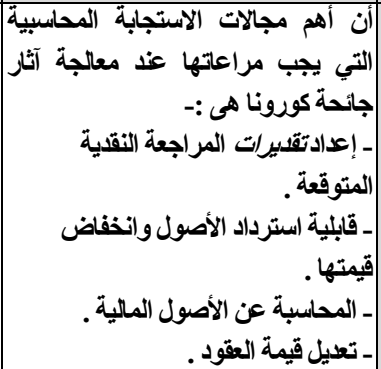 & 1 \\
\hline أوافق بشدة & $\$ .7$ & . & 1 & 0 & $r \wedge$ & 09 & 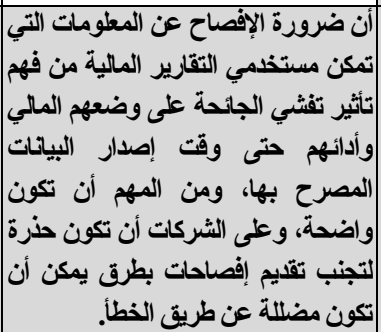 & $r$ \\
\hline أوافق بشدة & $\varepsilon .7$ & . & . & 7 & YT & 71 & 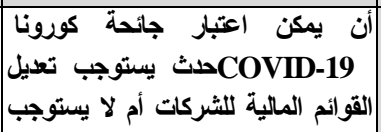 & $r$ \\
\hline
\end{tabular}




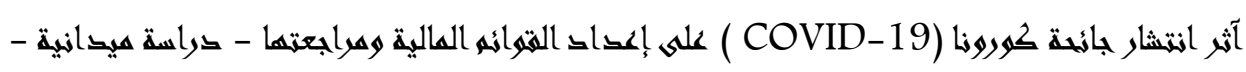
ڤ/ وليق سمير عبط العظيه الجبلمى

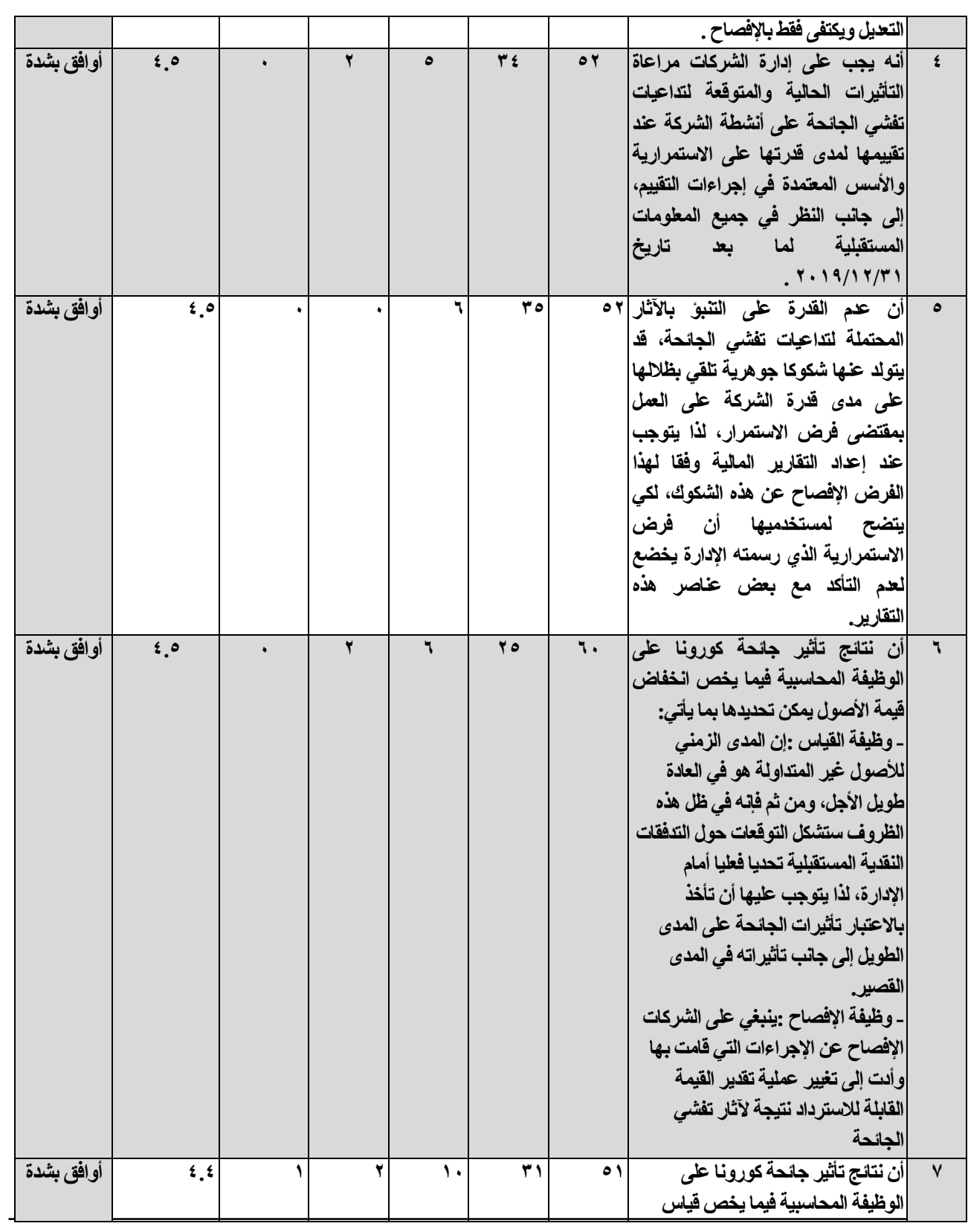

$|r| \varepsilon$

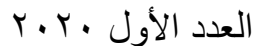




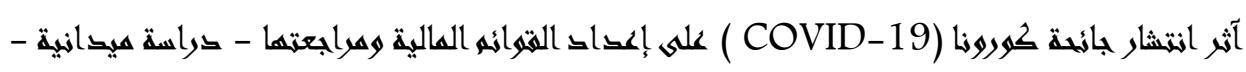

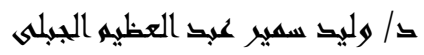

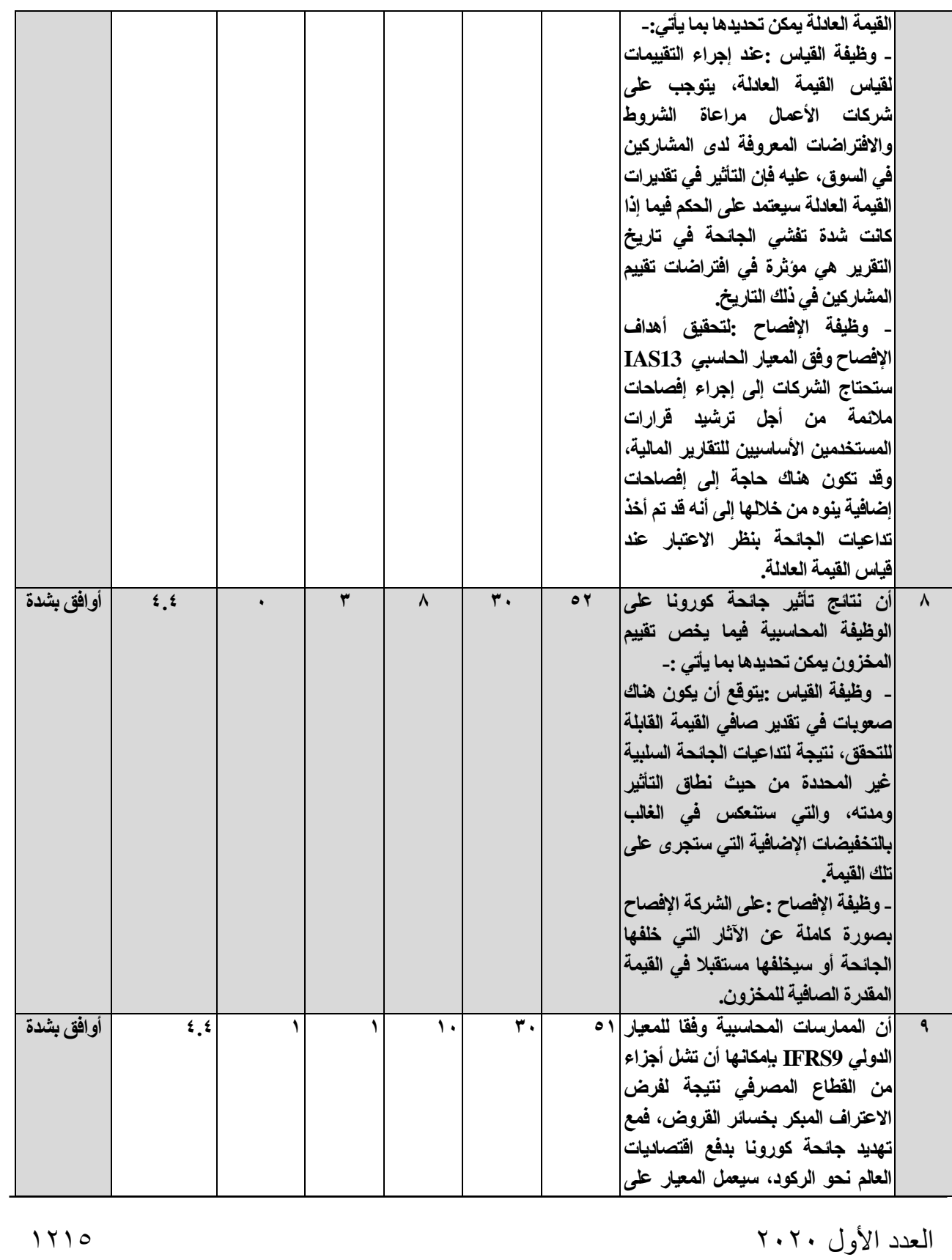




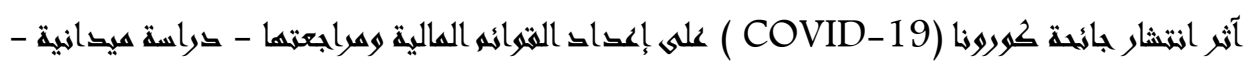
ڤ/ وليق سمير عبط العظيه الجبلمى

\begin{tabular}{|c|c|c|c|c|c|c|c|c|}
\hline & & & & & & & 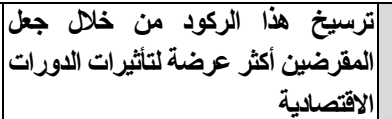 & \\
\hline أوافق بشدة & ६.६ & - & $r$ & $\Lambda$ & rr & 0. & 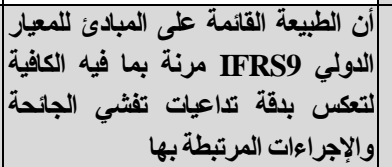 & 1. \\
\hline أوافق بثدة & \&.\& & . & $T$ & 9 & $r$. & Or & 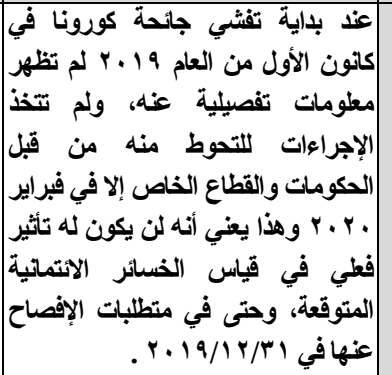 & 11 \\
\hline أوافق بشدة & $\varepsilon . \varepsilon^{2}$ & 1 & r & 1. & ro & 00 & 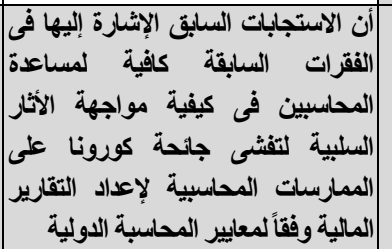 & Ir \\
\hline أوافق بشدة & \&.\& & & & & & لتقييم الع & & \\
\hline
\end{tabular}

المصدر : إعداد الباحث من مخرجات برنامج SPSS

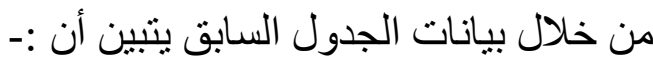

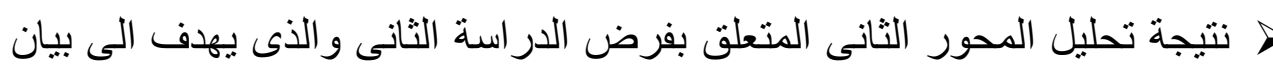

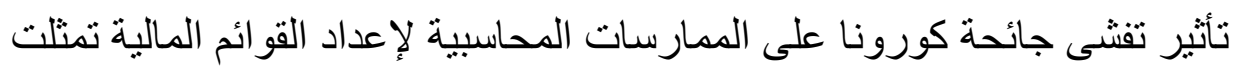

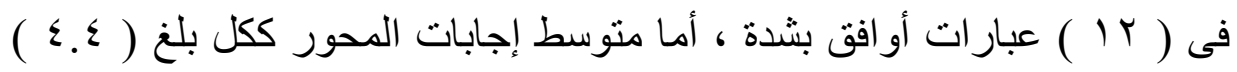

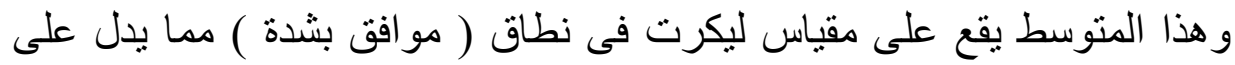

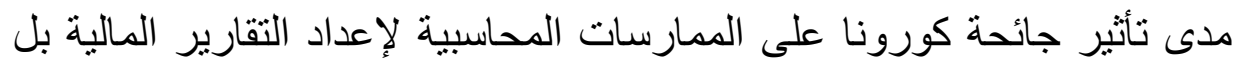
و على عملية تطبيق معايير إعداد التقارير المالية . 


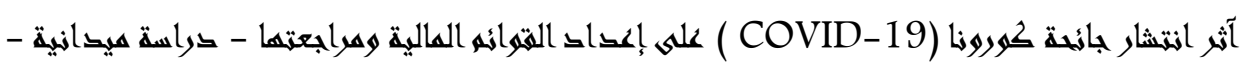
د/ وليد سمير عبد العظيه الجبملى

لر وبناءً على ما سبق يتم رفض الفرض الفرعى الثالث القائل " " لا توجد علاقة

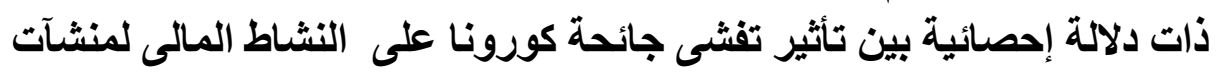

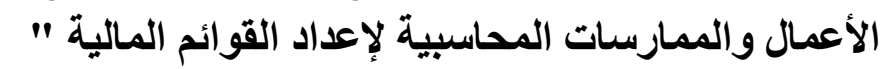

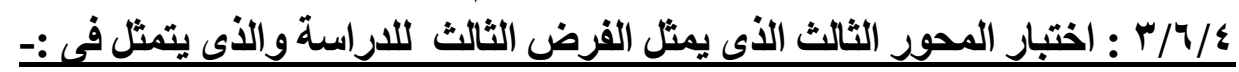

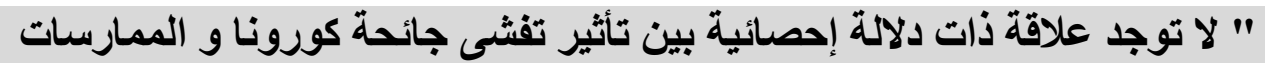

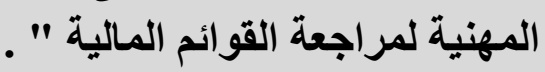
جدول رقم (7 ) اختبار المحور الثالث

\begin{tabular}{|c|c|c|c|c|c|c|c|c|}
\hline التعليق & المرجح & لا بثدة أفق & لا أوافق & محايد & أوافقى & بثدة أوافق & العبارة & p \\
\hline أوافقى بشدة & \&.r & - & . & $1 \varepsilon$ & $r 4$ & $\varepsilon r$ & 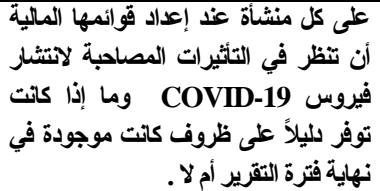 & 1 \\
\hline أوافق بثدة & \&.६ & . & . & 15 & \& & $r 7$ & 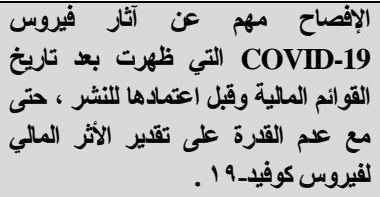 & r \\
\hline أوافق & \&. 1 & - & v & $\Lambda$ & \&0 & ru & 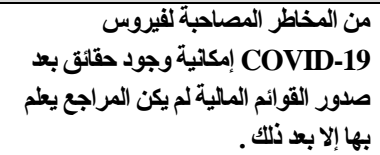 & $r$ \\
\hline أوافق بثدة & \&.६ & . & . & 7 & $\varepsilon \Lambda$ & rq & 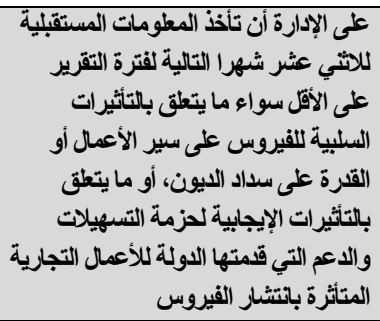 & $\xi$ \\
\hline أوافق بثدة & \&.r & 1 & 0 & 0 & $r v$ & $\leqslant 0$ & 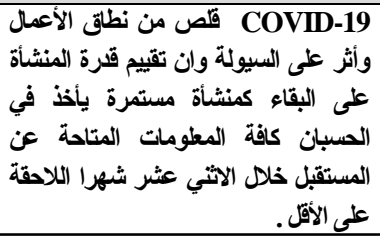 & 0 \\
\hline
\end{tabular}




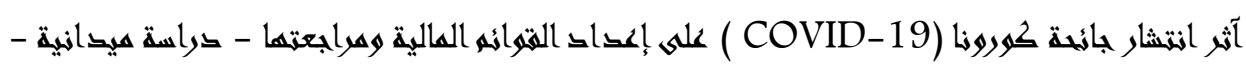
د/ وليق سمير عبد العظيه الجبملى

\begin{tabular}{|c|c|c|c|c|c|c|c|c|}
\hline أوافق & \&. 1 & . & $\Lambda$ & 0 & rq & 01 & 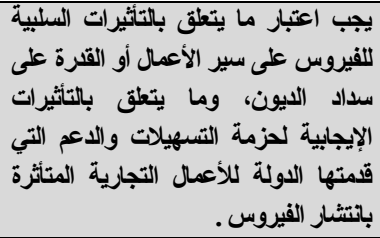 & 7 \\
\hline أوافق بثدة & $\varepsilon . r$ & $r$ & $r$ & $\mathrm{~V}$ & $r$. & 01 & 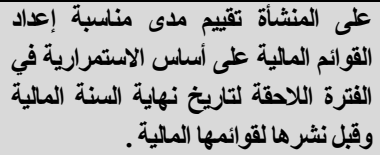 & $\mathrm{V}$ \\
\hline \multirow[t]{2}{*}{ أوافق بثدة } & $\varepsilon . r$ & 1 & $\varepsilon$ & $\mathrm{v}$ & rq & $\sum 0$ & 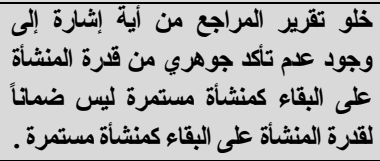 & $\Lambda$ \\
\hline & & & & & & & 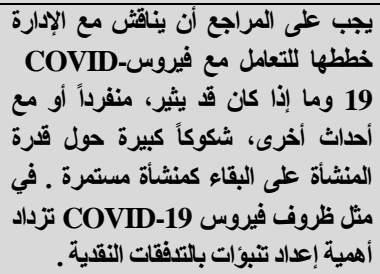 & 9 \\
\hline أوافق بشدة & £. & 1 & r & 1. & ro & 00 & 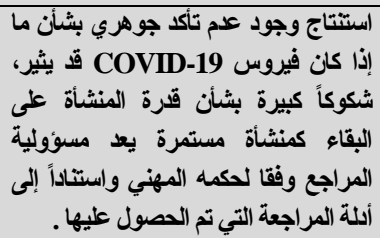 & 1. \\
\hline أوافق بشدة & $\varepsilon . \Gamma$ & - & $r$ & Ir & $\varepsilon \wedge$ & $r \xi$ & 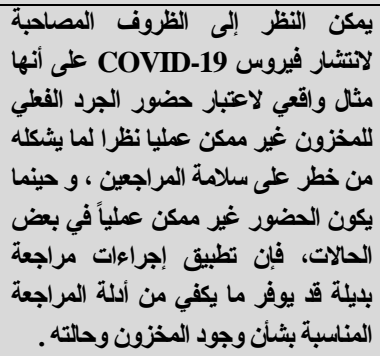 & 11 \\
\hline أوافق بشدة & \&. $Y$ & . & v & 1. & $\varepsilon V$ & TY & 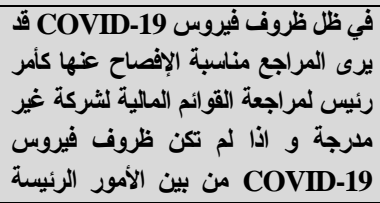 & Ir \\
\hline
\end{tabular}

IYIA

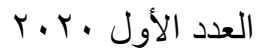




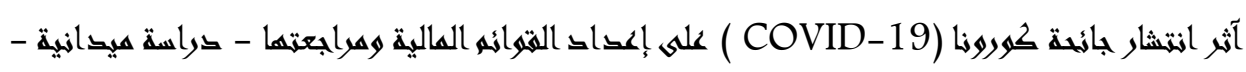
د/ وليق سمير عبد العظيه الجبلمى

\begin{tabular}{|c|c|c|c|c|c|c|c|c|}
\hline & & & & & & & 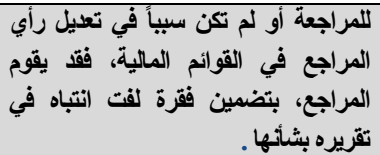 & \\
\hline أوافق & r.q & 0 & $\Lambda$ & $\pi$ & rq & rA & 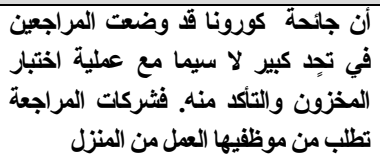 & it \\
\hline أوافق بشدة & $\varepsilon . Y$ & $\cdot$ & . & 11 & $r v$ & $r \Lambda$ & 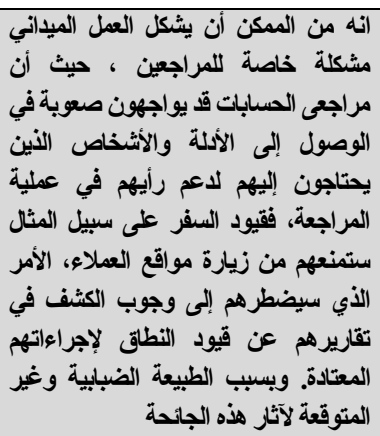 & $1 \varepsilon$ \\
\hline أوافق بشدة & $\varepsilon . r$ & . & $r$ & IY & $\varepsilon \Lambda$ & $r \varepsilon$ & 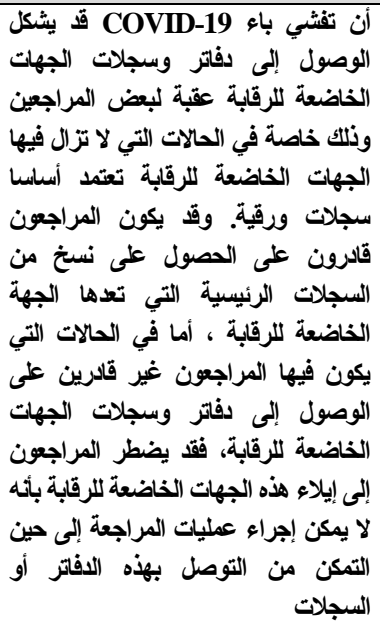 & 10 \\
\hline أوافق بشدة & $\varepsilon . Y$ & $\cdot$ & V & 1. & $\varepsilon V$ & rY & 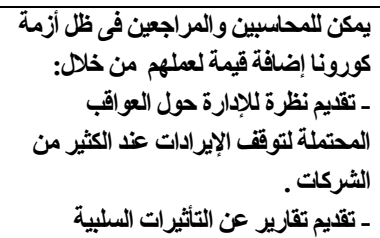 & 17 \\
\hline
\end{tabular}

1419

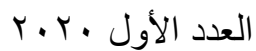




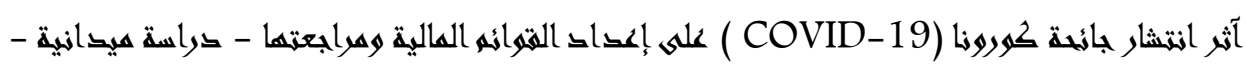

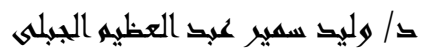

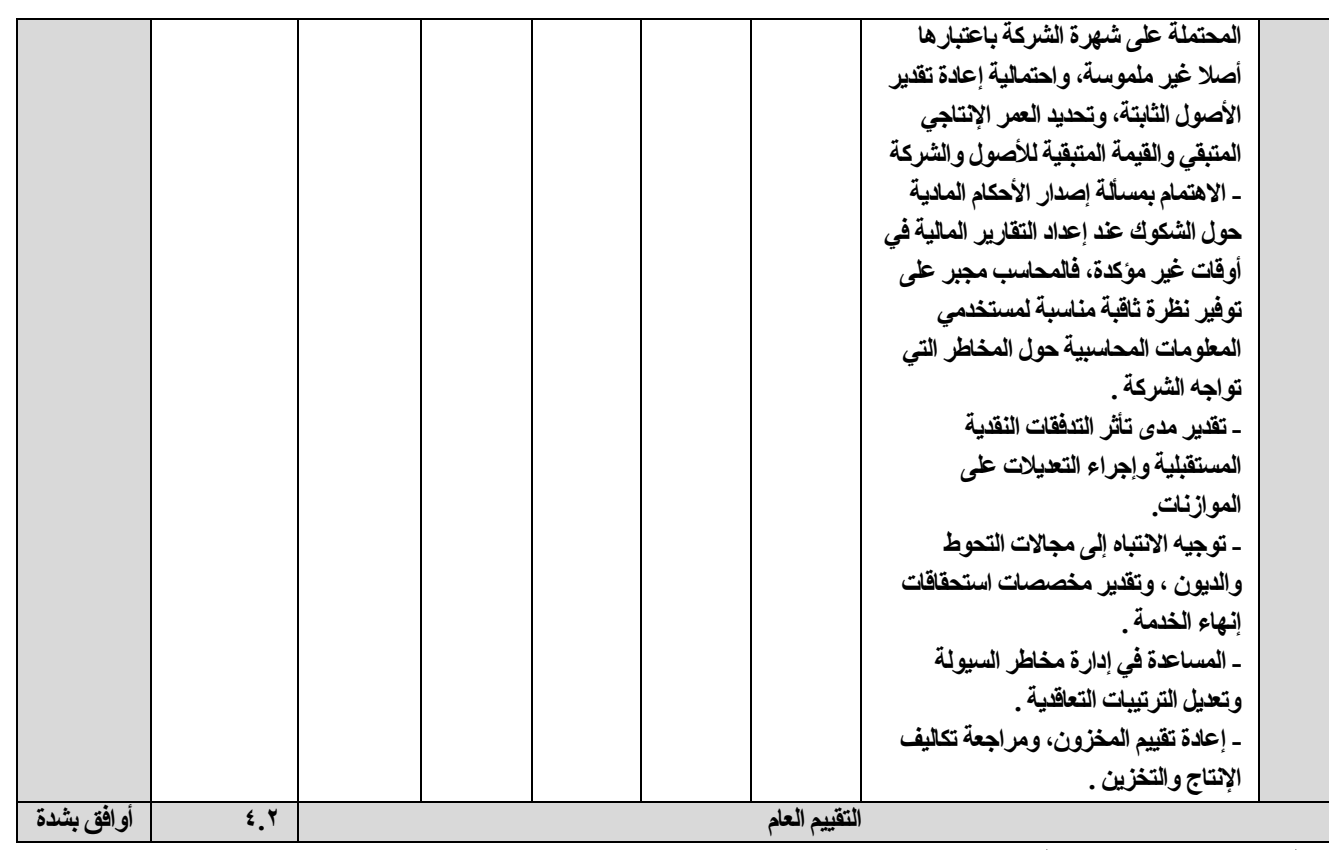

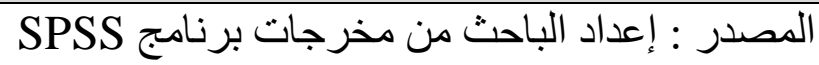
من خلال بيانات الجدول السابق يتبين أن :-

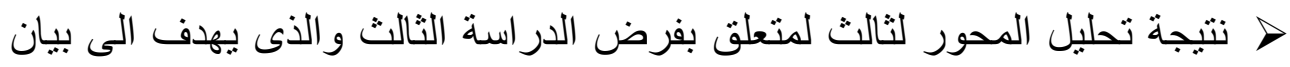

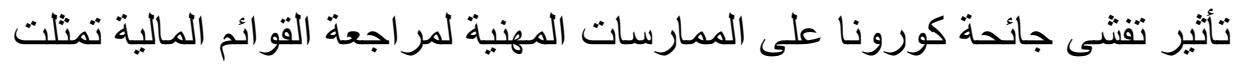

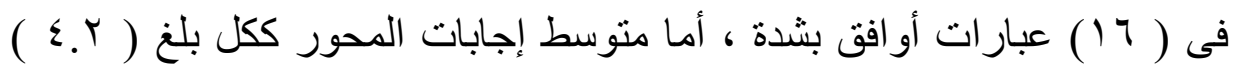

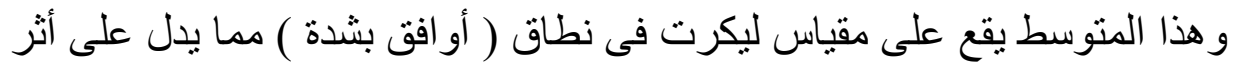

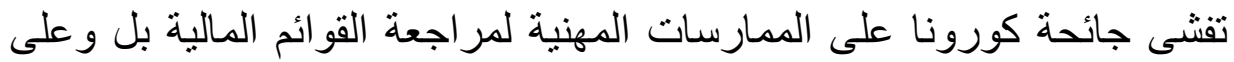

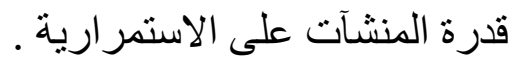

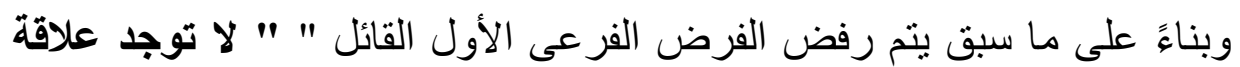
ذات دلالة إحصائية بين تأثير تفشى جائحة كورونا و الماتئ الممارسات المهنية

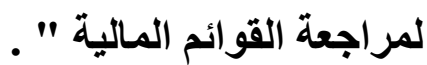

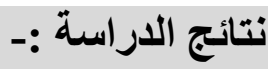




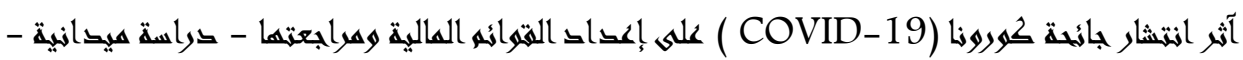
د/ وليق سمير عبد العظيه الجبلى

من خلال الإطار النظرى وتحليل بيانات الدراسة الميدانية تم التوصل الى النتائج

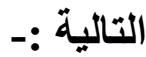
( ) معايير التقرير المالي مصممة للاستجابة للمتغير ات من خلال بنائها على المبادئ

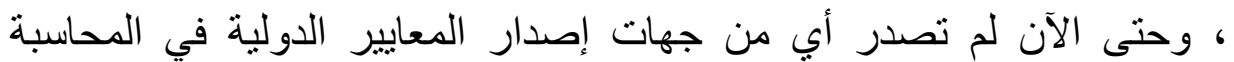

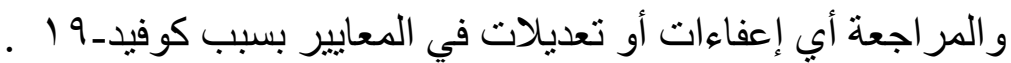

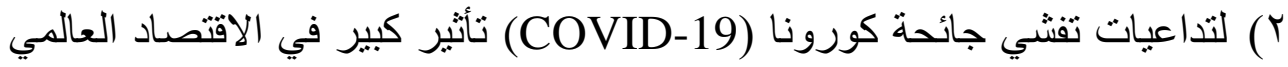

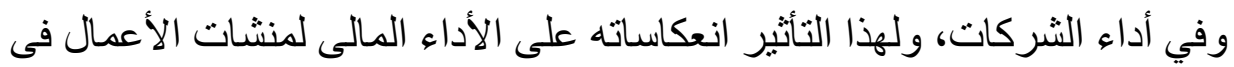

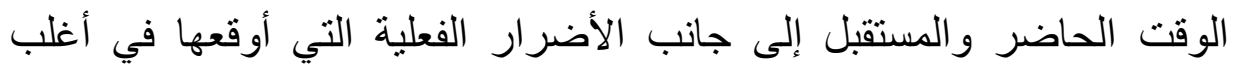
مفاصل اقتصاديات الدول ومجتمعاتها.

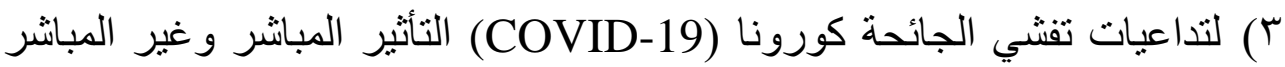

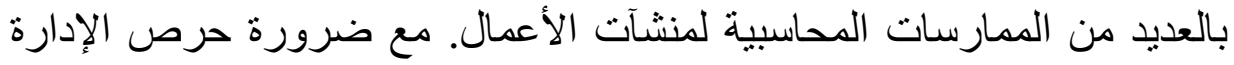

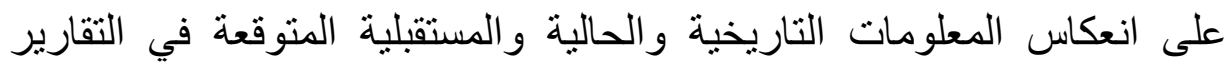

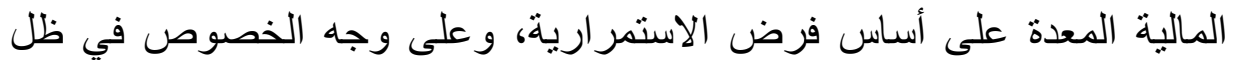
الضبابية وظروف عدم التأكد التي خلفها تفنثي الجائحة حيث التئ بمكن:

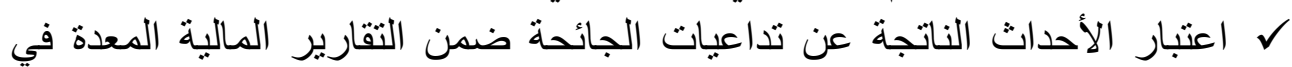

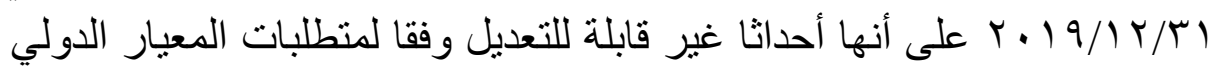
( IAS10)

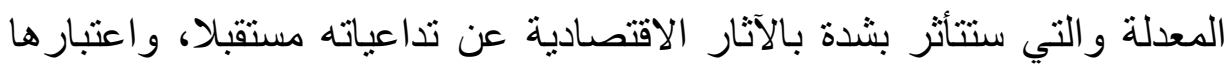

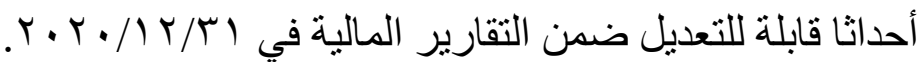

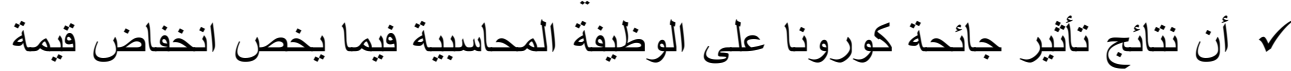

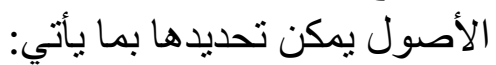
أـ وظيفة القياس :إن المدى الزمني للأصول غير المتداولة هو في في العادة طويل

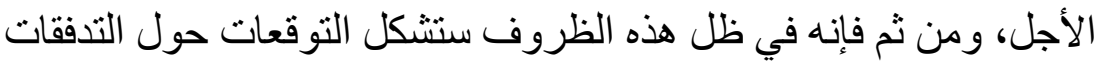

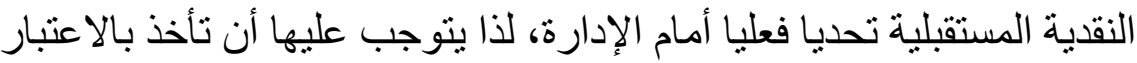

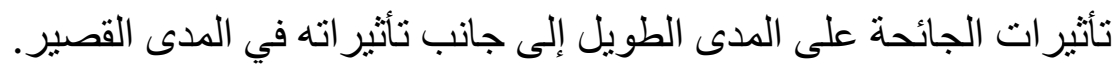




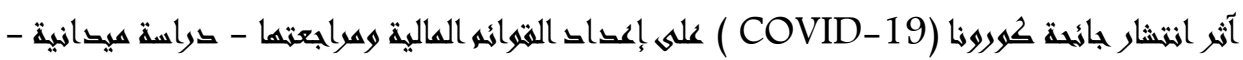
د/ وليب سمير عبد العظيه الجبملى

ب- وظيفة الإفصاح :ينبغي على الثركات الإفصاح عن الإجر اءات التي قامت

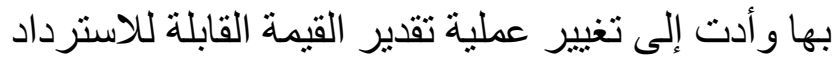

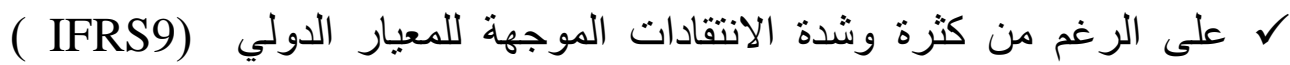

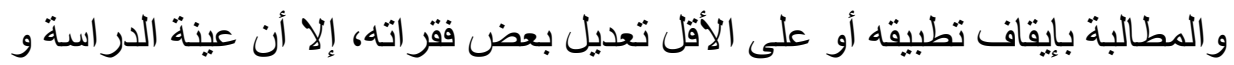

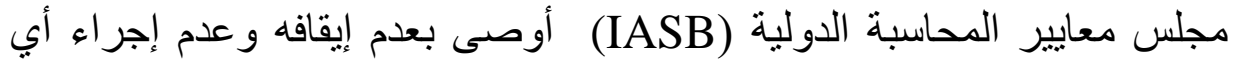
تعديل عليه خلال الفترة الحالية، على اعتبار أن فيه من المرونة التهائ التي تؤهله لاستيعاب الآثار الناتجة عن تفشي الجائحة.

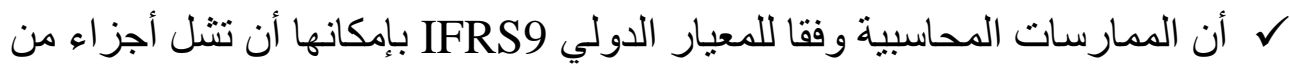
القطاع المصرفي نتيجة لفرض الاعتر اف المبكر بخسائر القروض، فئ في تهديد

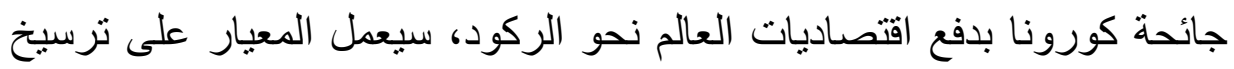

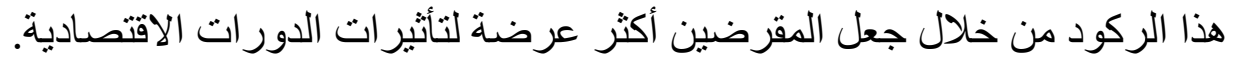
ل أن نتائج تأثثر جائحة كورونا على الوظيفة المحاسبية فيما يخص قياس القيمة القئ

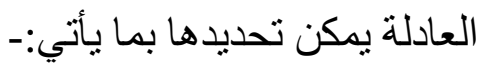

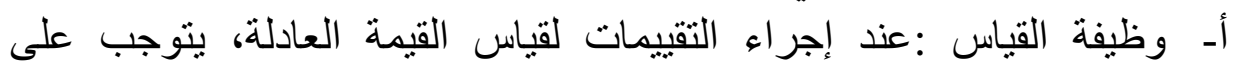
شركات الأعمال مر اعاة الثروط والافتر اضات المعروفة لدى المشاركين في ألي

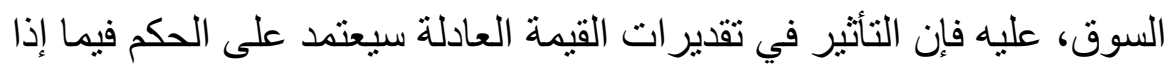
كانت شدة تفثي الجائحة في تاريخ التقرير هي مؤثرة في افتراضير اضات تقييم المشاركين في ذلك التاريخ.

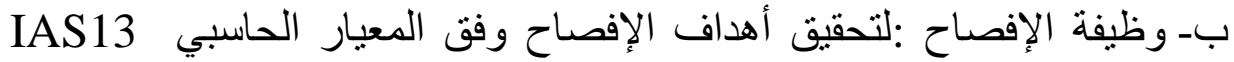

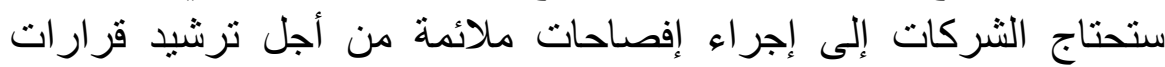

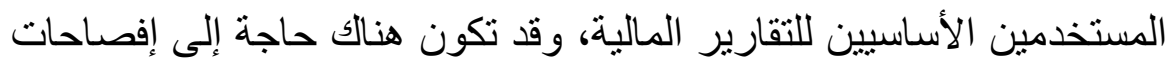

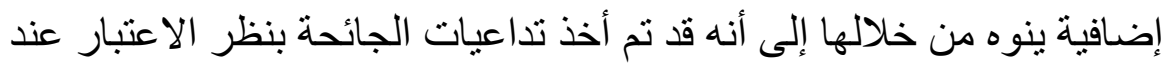
قياس القيمة العادلة. ع) ستتأثر الممارسات المهنية لمر اجعة القو ائم المالية لا محالة بتفشى جائحة كورونا حيث :- 


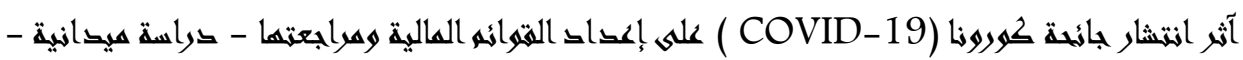
د/ وليق سمير عبد العظيه الجبلى

> يجب على المراجع أن يناقش مع الإدارة خططها للتعامل مع فيروس-COVID

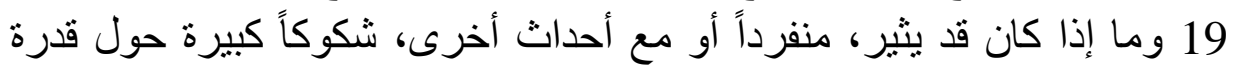

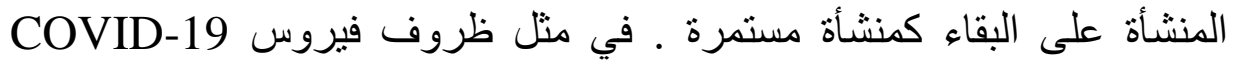

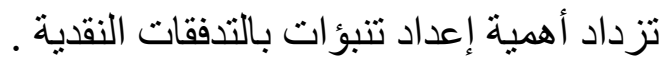

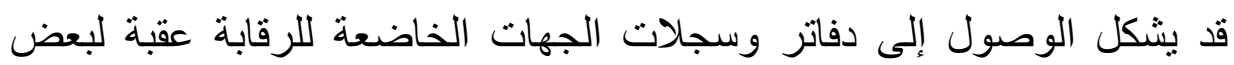

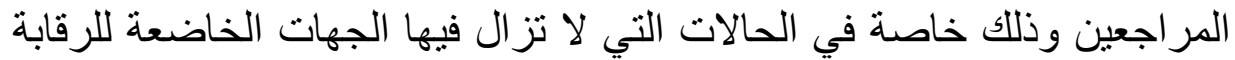

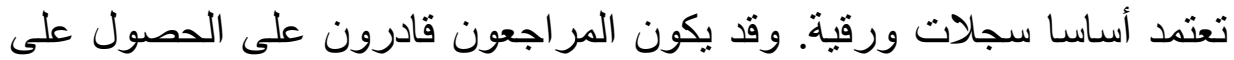

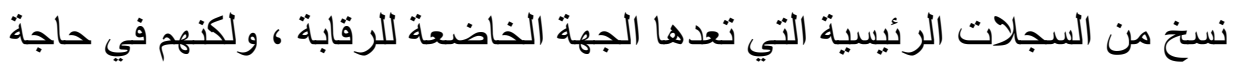
إلى التأكد من مدى صحة هذه السجلات وربما يحتاج المراجعون إلى القيام بإجر اءات مر اجعة إضافية للتأكد من أن تلك السجلات كاملة ودقيقة وصحيحة . يتطلب النظر في مخاطر الغش عددا من المتطلبات والإجراءات التي قد تكون التهن أكثر صعوبة عند إجراء عملية المراجعة عن بعدو سيظل المر اجعون بحاجة إلى إلى

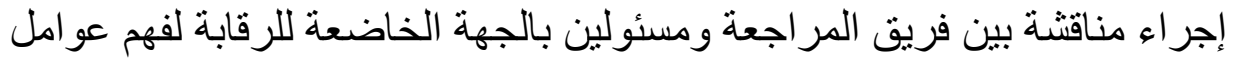

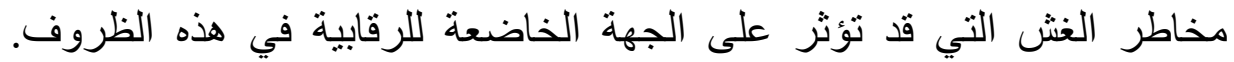
وتكون الاستفسارات مع المسئولين داخل الجهة الخاضعة للرقابة ألرابة أكثر فاعلية

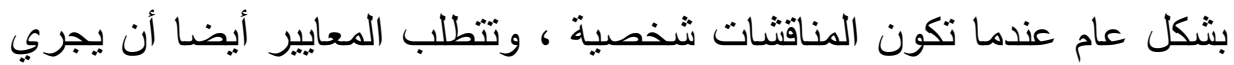

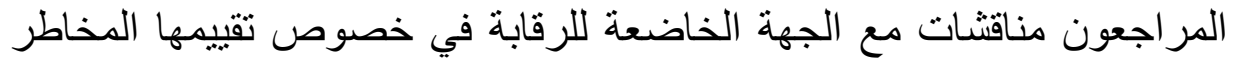

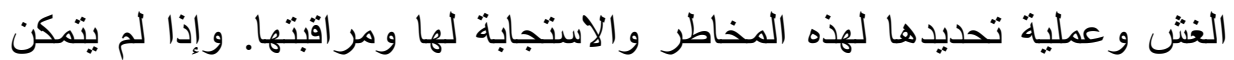
المر اجعون لأي سبب من الأسباب من استكمال هذه الإجراءات ، فئسيتعين عليهم

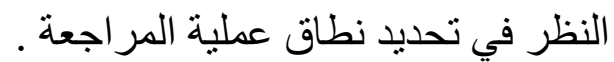

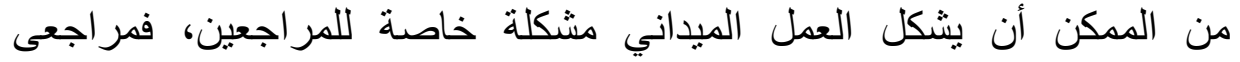

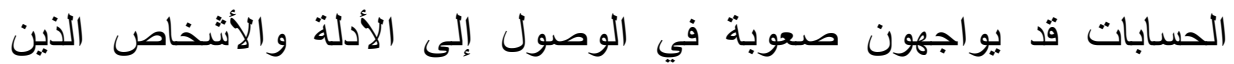
يحتاجون إليهم لاعم رأيهم في عملية المراجعة، فقيود السفر على سبيل فيل المثنال

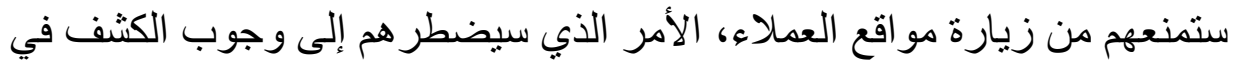

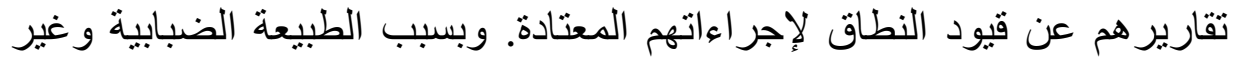




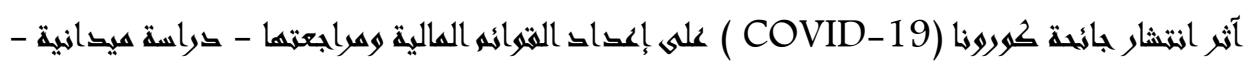
د/ وليد سهير عبد العظيه الجبلمى

المتوقعة لآثار هذه الجائحة ، فمن المتوقع أن تكون تقيماتهم للتقدير ات المحاسبية

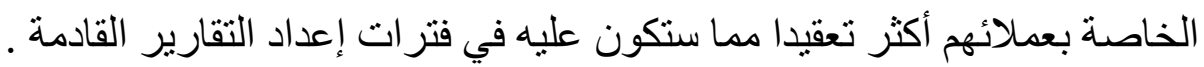

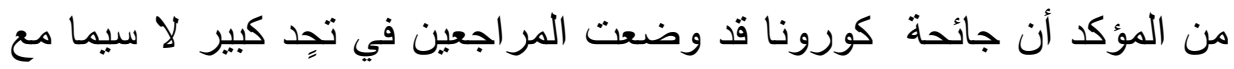

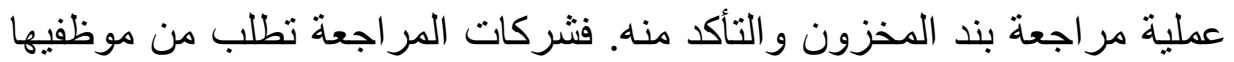

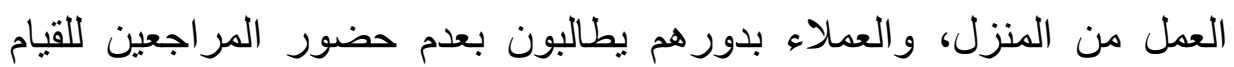

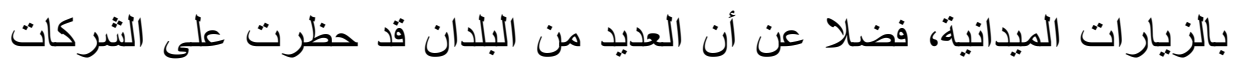

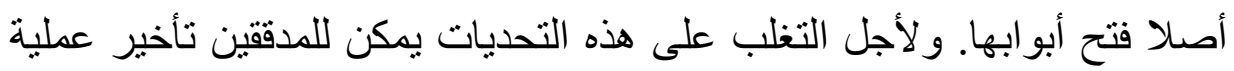
إعداد تقارير هم لفترة زمنية لحين انتهاء هذه الجائحة .

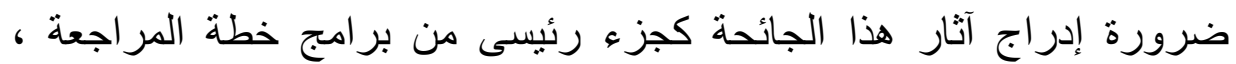

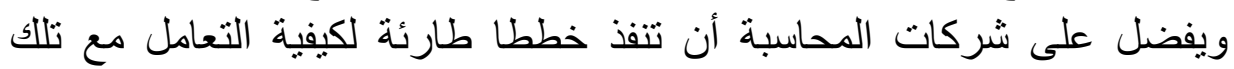
الآثار. 


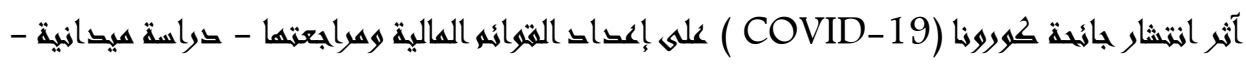
د/ وليد سمير عبد العظيه الجبملى

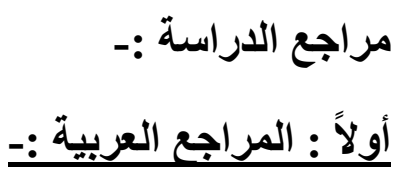

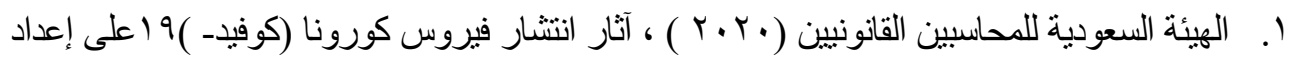

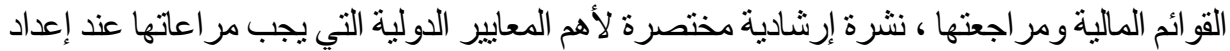

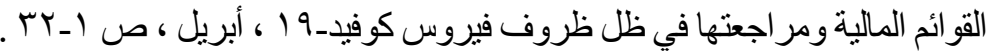

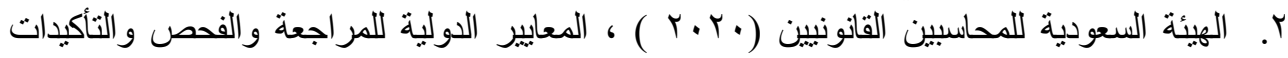

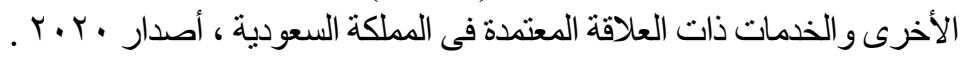

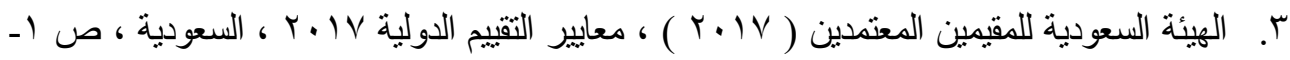
.109

1) Australian Securities \& Investment Commission (ASIC),(2020), COVID-19 implications for financial reporting and audit: Frequently asked questions (FAQs).

2) Badar Nadeem Ashraf , (2020), Stock markets' reaction to COVID-19: Cases or fatalities? , Research in International Business and Finance 54 ,p1-7 , https://doi.org/10.1016/j.ribaf.2020.101249.

3) $\mathrm{CEAOB},(2020)$, emphasises the following areas that are of high importance in view of Covid-19 impact on audits of financial statements , Adopted on 24 March, p1-2 .

4) Chan, Rick \& Chen, Narissa, (2020), Corona virus Outbreak and its Accounting and Audit Implications, MAZARS, Singapore.

5) Danyluk, Kerry, (2020), Clearly IFRS - Accounting Considerations Related to Corona virus Disease 2019, Delotte. Mar 31, 2020. https://www.iasplus.com

6) Dave, Sachin \& Mahanta, Vinod, (2020), Auditors feel companies may have to state corona virus impact in accounts. https://economictimes.indiatimes.

7) Dave, Sachin \& Mahanta, Vinod, (2020), Auditors feel companies may have to state corona virus impact in accounts. https://economictimes.indiatimes. 


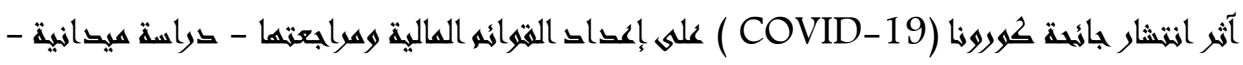
د/ وليد سهير عبد العظيه الجبملى

8) Delalio, John, (2020), How to Pivot Your Accounting Operations: Coping with COVID-19. https://www.eisneramper.com

9) Deloitte, (2020), FASB Decides to Defer Certain Effective Dates and Provides Guidance on COVID-19, Heads Up, Volume 27, Issue 7 .

10) Deloitte, (2020), Financial reporting considerations related to COVID-19 and an economic downturn , Financial Reporting Alert 20-2, March 25.

11) Deloitte, (2020), IFRS in Focus Accounting Considerations Related to Corona virus Disease 20 19, WWW2.Deloitte.com

12) Deloitte , (2019), IFRS in your pocket, p 1-136.

13) Dohrer, Bob, (2020), How auditors can test inventory without a site visit, journal of accountancy, march. https://www.journalofaccountancy.com

14) ESMA, (2020), Accounting implications of the COVID-19 outbreak on the calculation of expected credit losses in accordance with IFRS 9, www.esma.europa.eu.

15) ESMA, (2020), Accounting implications of the COVID-19 outbreak on the calculation of expected credit losses in accordance with IFRS 9, www.esma.europa.eu.

16) EY, (2017), Accounting for the financial impact of natural disasters, https://www.ey.com.

17) EY, (2020), IFRS accounting considerations of the Corona virus outbreak, EYGM Limited.

18) EY. (2020), Accounting considerations of the corona virus outbreak (Updated April 2020)

19) EY. (2020), IFRS accounting considerations of the Corona virus outbreak, www.cy.com

20) Financial Reporting Council ( FRC) (2020) . FRC advice to companies and auditors on corona virus risk disclosures, 18 February , https://www.frc.org.uk/news/february-2020-(1)/frc-advice-to-companiesand-auditors-on-coronaviru

21) Financial Reporting Council ( FRC) (2020) . FRC advice to companies and auditors on corona virtus risk diselostres, 18 February , IYYT

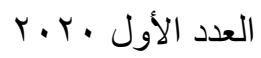




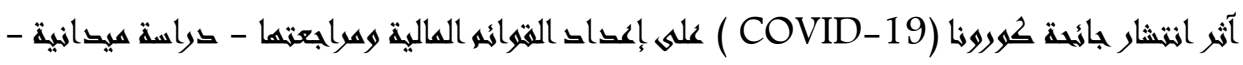
د/ وليد سهير عبد العظيه الجبملى

https://www.frc.org.uk/news/february-2020-(1)/frc-advice-to-companiesand-auditors-on-coronaviru

22) Financial Reporting Council ( FRC) (2020) . FRC advice to companies and auditors on corona virus risk disclosures, 18 February , https://www.frc.org.uk/news/february-2020-(1)/frc-advice-to-companiesand-auditors-on-coronaviru

23) Frank Richter, (2020), Accounting implications of the Corona virus, www.home.kpmg.com,

24) Grant Thornton, (2020) Reporting the impact of COVID-19 , https://www.grantthornton.global/en/insights/supporting-you-to-navigate-theimpact-of-covid-19/reporting-the-impact-of-covid-

25) IATA, (2020), Should corona virus be accounted for as an adjusting or nonadjusting event?, Airlines. magazine, https://www.iata.org.

26) IFAC ,(2020) , Summary of Covid-19 Financial Reporting Considerations, Christopher Arnold, Stathis Gould | June 3 .

27) IFRS (2020), IFRS 9 and covid-19,27 March .

28) Institute of Chartered Accountants in England and Wales , ICAEW, (2020) How to report on material uncertainty related to going concern - a guide for auditors https://www.icaew.com/technical/audit-and-assurance/professionalscepticism/coronavirus-considering-going-concern/how-to-report-onmaterial-uncertainty-related-to-going-concern-a-guide-for-auditors .

29) Institute of Chartered Accountants in England and Wales , ICAEW, (2020), Coronavirus (COVID-19): Considering the impact on group auditors, https://www.icaew.com/technical/audit-and-assurance/audit/groupaudit/coronavirus-guidance .

30) Institute of Chartered Accountants in England and Wales , ICAEW, (2020) ,Coronavirus (COVID-19): considering going concern - a guide for auditors , https://www.icaew.com/technical/audit-and-assurance/professionalscepticism/coronavirus-considering-going-concern.

31) Institute of Chartered Accountants in England and Wales , ICAEW, (2020), Coronavirus (COVID-19): Considerations for inventory audit testing , IYTV 


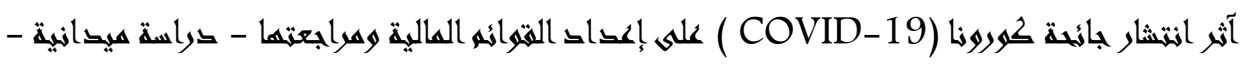
د/ وليد سهير عبد العظيه الجبملى

https://www.icaew.com/technical/audit-and-assurance/audit/qualitycontrol/coronavirus-considerations-for-inventory-audit-testing .

32) Institute of Chartered Accountants in England and Wales , ICAEW, (2020 ), Coronavirus: extensions to filing deadlines and changing reporting dates , https://www.icaew.com/insights/viewpoints-on-the-news/2020/mar2020/coronavirus-extensions-to-filing-deadlines-and-changing-reportingdates .

33) Institute of Chartered Accountants in England and Wales , ICAEW, (2020), COVID-19 and going concern - how accounts look to the future as well as the past https://www.icaew.com/technical/financial-reporting/uk-gaap/ukgaap-faqs/covid-19-and-going-concern-how-accounts-look-to-the-future-aswell-as-the-past .

34) Institute of Chartered Accountants in England and Wales , ICAEW, (2020), Coronavirus (COVID-19) Webcast: Considerations for auditing going concern https://www.icaew.com/technical/audit-andassurance/faculty/webcasts/covid-19-considerations-for-auditing-goingconcern.

35) Jessica Hollobaugh Giresi, (2020). Covid-19: Business Interruption Losses www.withum.com

36) John W. Goodell ,2020 ) COVID-19 and finance: Agendas for future research , 29 March , Finance Research Letters, p 1-5 https://doi.org/10.1016/j.frl.2020.101512 .

37) KPMG, (2020). Financial Reporting Hot Topics: Coronavirus Thoughts on financial instruments accounting, www.home.kpmg.com.

38) Maria L. Murphy, (2020), AICPA calls for IRS to provide tax relief during corona virus pandemic, www.compliance weck.com

39) Maria L. Murphy, (2020), AICPA calls for IRS to provide tax relief during corona virus pandemic, www.compliance weck.com

40) Moyer, Shannon, (2020), UK firms prepare for corona virus hit, https://www.accountancyage.com. 


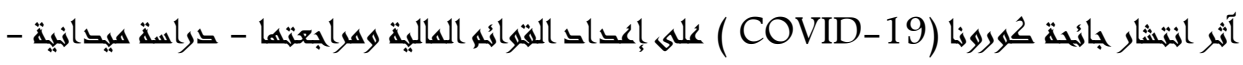
دا وليق سمير عبد العظيه الجبملى

41) Nicola M. White, (2020). Corona virus Disrupts Historic Credit Loss Accounting Overhaul. www.news.bloomberglaw.com

42) Noonan, Laura \& Morris, Stephen \& Arnold, Martin, (2020), New accounting rules pose threat to banks amid corona virus crisis. https://www.ft.com.

43) Noonan, Laura \& Morris, Stephen \& Arnold, Martin, (2020), New accounting rules pose threat to banks amid corona virus crisis. https://www.ft.com.

44) PWC, (2020) , COVID-19 Impact on IFRS 9, Expected Credit Loss, www.pwc.com .

45) PWC, (2020), Accounting implications of corona virus, www.pwc.com

46) PWC, (2020), Accounting implications of corona virus, www.pwc.com.

47) PWCs accounting podcast, (2020). Corona virus: Accounting considerations for your business, www.pwc.com .

48) PWC, (2019), 'IFRS overview , p1-60.

49) Richard Chambers, (2020). In the Face of the Corona virus, Internal Auditors Must Do More Than Don Masks, www.iaonline.theiia.org

50) Richter, Frank (2020), Accounting implications of the Corona virus, https://home.kpmg

51) Silvia (2020) , corona virus and IFRS - what is happening ? . https://www.ifrsbox.com/coronavirus-ifrs/

52) Tyler Davies, (2020), Corona crisis triggers global retracement on bank accounting standards. https://www.globalcapital.com.

53) Whitehouse, Geni, (2020), How Accountants Can Prepare Against Corona virus in This Busy Tax Season. https://www.acecloudhosting.co . 